\title{
VARIABILIDADE E TENDÊNCIA DA TEMPERATURA E PLUVIOSIDADE NOS MUNICÍPIOS DE PIRASSUNUNGA, RIO CLARO, SÃo CARLOS E SÃO SIMÃO (SP): ESTUDO SOBRE MUDANÇA CLIMÁTICA DE CURTO PRAZO EM ESCALA LOCAL
}

Tese apresentada à Escola de Engenharia de São Carlos, como parte dos requisitos para obtenção do Título de Doutor em Ciências da Engenharia Ambiental.

Orientador: Prof. Assoc. Francisco Vecchia 
AUTORIZO A REPRODUÇÃO E DIVULGAÇÃO TOTAL OU PARCIAL DESTE TRABALHO, POR QUALQUER MEIO CONVENCIONAL OU ELETRÔNICO, PARA FINS DE ESTUDO E PESQUISA, DESDE QUE CITADA A FONTE.

Ficha catalográfica preparada pela Seção de Tratamento da Informação do Serviço de Biblioteca - EESC/USP

Ferrari, Antonio Luiz

Variabilidade e tendência da temperatura e pluviosidade nos municípios de Pirassununga, Rio Claro, São Carlos e São Simão (SP): estudo sobre mudança climática de curto prazo em escala local / Antonio Luiz Ferrari; orientador Francisco Artur Vecchia.-- São Carlos, 2011.

Tese (Doutorado - Programa de Pós-Graduação e Área de Concentração em Engenharia Ambiental) -- Escola de Engenharia de São Carlos da Universidade de São Paulo, 2012 .

1. Temperatura. 2. Pluviosidade. 3. Tendência. 4. Variabilidade. 5. Análise Estatística 


\section{FOLHA DE JULGAMENTO}

\section{Candidato: Licenciado ANTONIO LUIZ FERRARI.}

Título da tese: "Variabilidade e tendência da temperatura e pluviosidade nos municípios de Pirassununga, Rio Claro, São Carlos e São Simão (SP): estudo sobre mudança climática de curto prazo em escala local".

Data da defesa: 04/10/2012

\section{Comissão Julgadora:}

Prof. Associado Francisco Arthur da Silva Vecchia (Orientador) (Escola de Engenharia de São Carlos/EESC)

Prof ${ }^{\text {a }}$. Dr ${ }^{\mathrm{a}}$. Sandra Elisa Contri Pitton (Universidade Estadual Paulista "Júlio de Mesquita Filho"/UNESP-Rió Claro)

Prof ${ }^{\mathrm{a}}$. Dr ${ }^{\mathrm{a}}$. Rosângela de Oliveira Colabone

(Academia da Força Aérea/AFA-Pirassununga)

Prof. Dr. Laércio Aparecido Lucas

(Academia da Força Aérea/AFA-Pirassununga)

Prof. Dr. Adriano Rogério Bruno Tech

(Faculdade de Zootecnia e Engenharia de Alimentos/USP)

\section{Resultado:}

\section{Anovado}

APRO JADO Saudra Eelsi loutrifitton

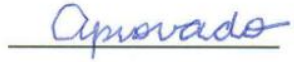

APROVATO

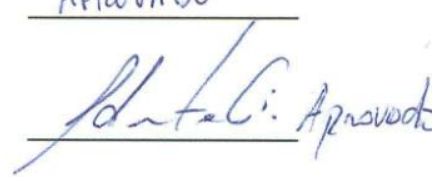

Coordenador do Programa de Pós-Graduação em Ciências da Engenharia Ambiental: Prof. Dr. Frederico Fabio Mauad

Presidente da Comissão de Pós-Graduação:

Prof. Titular Denis Vinicius Coury 
À minha família e aos meus amigos que sempre estiveram ao meu lado.

Dedico 


\section{AGRADECIMENTOS}

- À Deus, pelo dom da vida e da sabedoria;

- Ao Prof. Dr. Francisco Vecchia, meu orientador, que me aceitou como aluno, indicou os caminhos necessários e confiou no meu trabalho;

- À Profa. Dra. Rosângela de Oliveira Colabone, amiga e incentivadora, por todos os auxílios prestados, mas principalmente pela força e encorajamento nos momentos mais difíceis;

- Ao Prof. Dr. Laércio Aparecido Lucas, da Academia da Força Aérea, pelo direcionamento e formas de aplicação das técnicas estatísticas no tratamento dos dados;

- Ao Prof. Dr. João Afonso Zavattini, do Departamento de Geografia da UNESP de Rio Claro, pelos ensinamentos e incentivo;

- À minha família por ter compreedido que a ausência temporária foi extremamente necessária para a conclusão do trabalho;

- Aos amigos da AFA, Sonia, Roseli, Natale, Cristiano, Paulo Magno, Carlos Bispo, Luciane e Adriano pela valiosa ajuda;

- Ao Instituto de Controle do Espaço Aéreo - ICEA de São José dos Campos, pela concessão dos dados climatológicos utilizados nesta pesquisa;

- À Academia da Força Aérea, pelos afastamentos concedidos para elaboração deste trabalho;

- Aos funcionários da Secretaria do CRHEA, pelo tratamento atencioso e paciente;

- À todas as pessoas que me ajudaram, me incentivaram e torceram por mim e que, de alguma forma, contribuíram para que o trabalho fosse realizado. 


\section{VARIABILIDADE E TENDÊNCIA DA TEMPERATURA E PLUVIOSIDADE NOS MUNICÍPIOS DE PIRASSUNUNGA, RIO CLARO, SÃO CARLOS E SÃO SIMÃO (SP): ESTUDO SOBRE MUDANÇA CLIMÁTICA DE CURTO PRAZO EM ESCALA LOCAL}

RESUMO: O objetivo desta pesquisa é estudar a variabilidade e tendência dos elementos climáticos pluviosidade e temperatura, em quatro localidades do estado de São Paulo Pirassununga, Rio Claro, São Carlos e São Simão -, que constituem parte da área de treinamento de voo da Academia da Força Aérea, para confirmar a hipótese de que essas alterações indicam indícios de mudanças climáticas de curto prazo, em escala local e que essas mudanças poderão afetar, no futuro, o planejamento das missões de treinamento de voo na AFA. Para isso foram utilizados, primeiramente, os dados mensais e anuais de temperatura e pluviosidade de uma série temporal de 34 anos (1976 a 2009) e, depois, de uma série mais curta, de 16 anos (1994 a 2009). Para a análise das condições climáticas de São Carlos, Rio Claro e São Simão foram utilizados os dados mensais e anuais de temperatura e pluviosidade de uma série temporal de 16 anos (1994 a 2009). Para efeito da análise estatística da variabilidade climática da temperatura e pluviosidade dentro da série temporal escolhida, foram aplicados os cálculos da média aritmética, do desvio padrão, do coeficiente de variação e da amplitude térmica. Para a análise da tendência, aplicou-se a técnica da regressão linear e os testes estatísticos não-paramétricos, conhecidos como testes de Mann-Kendall e Curvatura de Sen. Os resultados da pesquisa mostraram que a variabilidade mensal e anual da pluviosidade para as quatro localidade é semelhante e bem acentuada e que não existem tendências significativas para essa variável nas quatro localidades. Para as temperaturas em Pirassununga, a temperatura média apresentou grande variabilidade mensal. Para Rio Claro, São Carlos e São Simão a variabilidade anual das temperaturas foi baixa, próxima da estabilidade, com exceção da temperatura mínima, que apresentou grande variabilidade para as três localidades. Quanto à tendência para Pirassununga, apenas a temperatura média apresentou tendência decrescente e significativa. Os resultados obtidos para as temperaturas de Rio Claro, São Carlos e São Simão indicam tendências crescentes e/ou decrescentes, mas todas insignificantes.

PALAVRAS-CHAVE: elementos climáticos; tendência; variabilidade; análise estatística; Mann-Kendall; Curvatura de Sen. 


\title{
VARIABILITY AND TRENDS IN TEMPERATURE AND RAINFALL IN THE MUNICIPAL \\ OF PIRASSUNUNGA, RIO CLARO, SÃO CARLOS AND SÃO SIMÃO (SP-BRAZIL): STUDY ON CLIMATE CHANGE IN SHORT TERM ON LOCAL SCALE
}

\begin{abstract}
The aim of this research is to study the variability and tendency in climatic elements, rainfall and temperature in four cities in the state of São Paulo: Pirassununga, Rio Claro, São Carlos and São Simão which are part of the flight training area of the Air Force Academy, in order to confirm the hypothesis that those alterations indicate signs of climatic variations in the short term, according to the local parameters and that those variations may change the schedule of the flight training missions at AFA. Monthly and annual data regarding to temperature and rainfall, recorded during a period of 34 years (1976-2009) were firstly considered during the study, followed by a shorter period of 16 years (1994-2009). In order to analyze the climatic conditions in São Carlos, Rio Claro and São Simão, monthly and annual data about temperature and rainfall collected during a period of 16 years (1994-2009) were considered. For purposes of statistical analysis of the climatic variability of temperature and rainfall within the chosen period of time, calculation of the arithmetic mean, standard deviation, coefficient of variation and temperature range were applied. In order to analyze such tendency, the linear regression model and non-parametric statistical tests, known as Mann-Kendall and Sen Curvature were applied. The results of the research showed that the monthly and annual variability of the rainfall in the four cities is similar and well marked and that there are not significant tendencies in that variable in the four cities. Relating to temperature in Pirassununga, the average temperature showed large monthly variability. In Rio Claro, São Carlos and São Simão, the annual temperature variability was low, tending to be stable, except for the minimum temperature which showed a large variability. Concerning to Pirassununga, just the average temperature tended to be decreasing and significant. The results obtained for the temperatures in Rio Claro, São Carlos and São Simão tended to be increasing and/or decreasing, but such tendencies were irrelevant.
\end{abstract}

KEY-WORDS: climatic elements ; variability; Mann-Kendall; Sen Curvature; statistical analysis. 


\section{LISTA DE TABELAS}

Tabela 1 - Valores da temperatura média, desvio padrão (DP) e coeficiente de variação $(\mathrm{CV})$ da temperatura média anual e mensal no município de Pirassunung/SP para os anos de 1976 a 2009.

Tabela 2 - Valores da temperatura máxima, desvio padrão (DP) e coeficiente de variação $(\mathrm{CV})$ da temperatura máxima anual e mensal no município de Pirassunung/SP para os anos de 1976 a 2009

Tabela 3 - Valores da temperatura mínima, desvio padrão (DP) e coeficiente de variação $(\mathrm{CV})$ da temperatura mínima anual e mensal no município de Pirassunung/SP para os anos de 1976 a 2009.

Tabela 4 - Valores da pluviosidade total anual no município de Pirassununga/SP para os anos de 1976 a 2009

Tabela 5 - Valores de média, desvio padrão (DP) e coeficiente de variação (CV) da pluviosidade média anual e mensal no município de Pirassununga/SP para os anos de 1976 a 2009

Tabela 6 - Medidas estatísticas das temperaturas máximas, médias máximas, mínimas, médias mínimas, médias e pluviosidade de Pirassununga 1976 a 2009.

Tabela 7 - Medidas estatísticas de tendência das variáveis meteorológicas ( $\alpha=5 \%$ ) para Pirassununga/SP -1976 a 2009.

Tabela 8 - Valores da temperatura média anual no município de Pirassununga/SP para a série temporal de 1994 a 2009.

Tabela 9 - Valores da temperatura média, desvio padrão (DP) e coeficiente de variação $(\mathrm{CV})$ da temperatura média anual e mensal no município de Pirassununga/SP para os anos de 1994 a 2009

Tabela 10 - Valores da temperatura máxima anual no município de Pirassununga/SP para a série temporal de 1994 a 2009.

Tabela 11 - Valores da temperatura máxima, desvio padrão (DP) e coeficiente de variação $(\mathrm{CV})$ da temperatura máxima anual e mensal no município de Pirassununga/SP para os anos de 1994 a 2009

Tabela 12 - Valores da temperatura mínima anual no município de Pirassununga/SP para a série temporal de 1994 a 2009.

Tabela 13 - Valores da temperatura mínima, desvio padrão (DP) e coeficiente de variação $(\mathrm{CV})$ da temperatura máxima anual e mensal no município de Pirassununga/SP para os anos de 1994 a 2009. 
Tabela 14 - Valores da pluviosidade total anual no município de Pirassununga/SP para os anos de 1994 a 2009.

Tabela 15 - Valores de média, desvio padrão (DP) e coeficiente de variação (CV) da pluviosidade média anual e mensal, no município de Pirassununga/SP para os anos de 1994 a 2009

Tabela 16 - Medidas estatísticas de temperatura máxima, temperatura média máxima, temperatura mínima, temperatura média mínima e pluviosidade para Pirassununga/SP

Tabela 17 - Análise Estatística das Variáveis Meteorológicas $(\alpha=5 \%)$ para Pirassununga (SP) - 1994 a 2009

Tabela 18 - Valores da temperatura média anual no município de Rio Claro/SP para a série temporal de 1994 a 2009

Tabela 19 - Valores da temperatura média, desvio padrão (DP) e coeficiente de variação $(\mathrm{CV})$ da temperatura média anual e mensal no município de Rio Claro/SP Para os anos de 1994 a 2009

Tabela 20 - Valores da temperatura máxima anual no município de Rio Claro/SP para a série temporal de 1994 a 2009.

Tabela 21 - Valores da temperatura máxima, desvio padrão (DP) e coeficiente de variação $(\mathrm{CV})$ da temperatura média anual e mensal no município de Rio Claro/SP para os anos de 1994 a 2009

Tabela 22 - Valores da temperatura mínima anual no município de Rio Claro/SP para a série temporal de 1994 a 2009.

Tabela 23 - Valores da temperatura mínima, desvio padrão (DP) e coeficiente de variação $(\mathrm{CV})$ da temperatura média anual e mensal no município de Rio Claro/SP para os anos de 1994 a 2009.

Tabela 24 - Valores da temperatura média máxima anual no município de Rio Claro/SP para a série temporal de 1994 a 2009.

Tabela 25 - Valores da temperatura média mínima anual no município de Rio Claro/SP para a série temporal de 1994 a 2009.

Tabela 26 - Valores da pluviosidade total anual no município de Rio Claro/SP para a série temporal de 1994 a 2009.

Tabela 27 - Valores da média, desvio padrão (DP) e coeficiente de variação (CV) da pluviosidade média anual e mensal no município de Rio Claro/SP para os anos de 1994 a 2009.

Tabela 28 - Medidas estatísticas de temperatura máxima, temperatura média máxima, temperatura mínima, temperatura média mínima, temperatura média e pluviosidade para Rio Claro/SP. 
Tabela 29 - Análise Estatística das Variáveis Meteorológicas $(\alpha=5 \%)$ para Rio Claro/SP......

Tabela 30 - Valores da temperatura média anual no município de São Carlos/SP para a série temporal de 1994 a 2009.

Tabela 31 - Valores da temperatura média, desvio padrão (DP) e coeficiente de variação $(\mathrm{CV})$ da temperatura média anual e mensal no município de São Carlos/SP para os anos de 1994 a 2009

Tabela 32 - Valores da temperatura máxima anual no município de São Carlos/SP para a série temporal de 1994 a 2009.

Tabela 33 - Valores da temperatura máxima, desvio padrão (DP) e coeficiente de variação $(\mathrm{CV})$ da temperatura média anual e mensal no município de São Carlos/SP para os anos de 1994 a 2009.

Tabela 34 - Valores da temperatura mínima anual no município de São Carlos/SP para a série temporal de 1994 a 2009.

Tabela 35 - Valores da temperatura mínima, desvio padrão (DP) e coeficiente de variação $(\mathrm{CV})$ da temperatura média anual e mensal no município de São Carlos/SP para os anos de 1994 a 2009.

Tabela 36 - Valores da temperatura média máxima anual no município de São Carlos/SP para a série temporal de 1994 a 2009.

Tabela 37 - Valores da temperatura média mínima anual no município de São Carlos/SP para a série temporal de 1994 a 2009

Tabela 38 - Valores da pluviosidade total anual no município de São Carlos/SP para a série temporal de 1994 a 2009.

Tabela 39 - Valores da média, desvio padrão (DP) e coeficiente de variação (CV) da pluviosidade média anual e mensal no município de São Carlos/SP para os anos de 1994 a 2009

Tabela 40 - Medidas estatísticas de temperatura máxima, temperatura média máxima, temperatura mínima, temperatura média mínima e pluviosidade para São Carlos/SP.

Tabela 41 - Análise estatística das variáveis meteorológicas $(\alpha=5 \%)$ para São Carlos/SP.

Tabela 42 - Valores da temperatura média anual no município de São Simão/SP para a série temporal de 1994 a 2009.

Tabela 43 - Valores da temperatura média, desvio padrão (DP) e coeficiente de variação $(\mathrm{CV})$ da temperatura média anual e mensal no município de São Simão/SP para os anos de 1994 a 2009

Tabela 44 - Valores da temperatura máxima anual no município de São Simão/SP para a série temporal de 1994 a 2009. 
Tabela 45 - Valores da temperatura máxima, desvio padrão (DP) e coeficiente de variação $(\mathrm{CV})$ da temperatura média anual e mensal no município de São Simão/SP para os anos de 1994 a 2009

Tabela 46 - Valores da temperatura mínima, anual no município de São Simão/SP, para a série temporal de 1994 a 2009.

Tabela 47 - Valores da temperatura mínima, desvio padrão (DP) e coeficiente de variação $(\mathrm{CV})$ da temperatura média anual e mensal no município de São Simão/SP para os anos de 1994 a 2009

Tabela 48 - Valores da temperatura média máxima anual no município de São Simã/SP para a série temporal de 1994 a 2009.

Tabela 49 - Valores da temperatura média mínima anual no município de São Simã/SP para a série temporal de 1994 a 2009.

Tabela 50 - Valores da pluviosidade total anual no município de São Simão/SP para a série temporal de 1994 a 2009.

Tabela 51 - Valores da média, desvio padrão (DP) e coeficiente de variação (CV) da pluviosidade média anual e mensal no município de São Simão/SP para os anos de 1994 a 2009

Tabela 52 - Medidas estatísticas de temperatura máxima, temperatura média máxima, temperatura mínima, temperatura média mínima, e pluviosidade para São Simão/SP...

Tabela 53 - Análise estatística das variáveis meteorológicas $(\alpha=5 \%)$ para São Simão/SP.

Tabela 54 - Análise comparativa da estatística $\mathrm{Z}$ das variáveis meteorológicas $(\alpha=5 \%)$

Tabela 55 - Análise comparativa da estatística curvatura de Sen das variáveis meteorológicas. 


\section{SUMÁRIO}

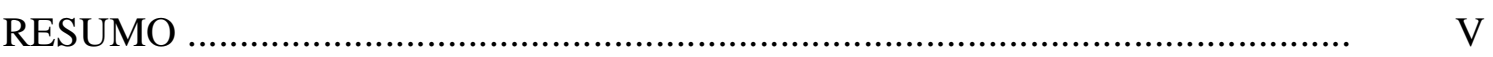

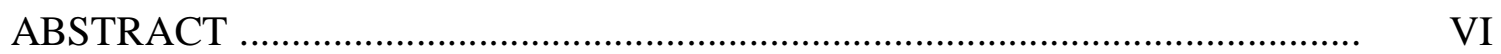

LISTA DE TABELAS …..................................................................... VII

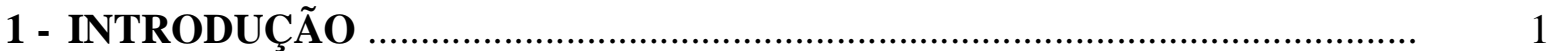

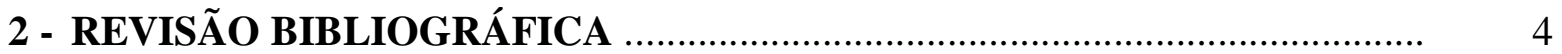

2.1- Mudanças climáticas .................................................................................... 4

2.2- Variabilidade e tendência climática ............................................................... 11

2.2.1- Variabilidade climática ....................................................................... 11

2.2.2- Tendência climática .......................................................................... 13

2.3- Aplicações estatísticas em climatologia .................................................... 14

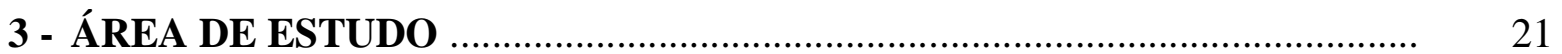

3.1- Caracterização física dos municípios de Pirassununga, Rio Claro, São Carlos e São Simão ........................................................................... 21

3.2- Aspectos físicos do município de Pirassununga....................................... 22

3.2.1- Aspectos geológicos e geomorfológicos do município de Pirassununga 22

3.2.2- Aspecto climáticos do município de Pirassununga ................................ 23

3.3- Aspectos físicos do município de Rio Claro ..................................................... 23

3.3.1 - Aspectos geológicos e geomorfológicos do município de Rio Claro ... $\quad 24$

3.3.2 - Aspectos climáticos do município de Rio Claro ................................... 24

3.4- Aspectos físicos do município de São Carlos .............................................. 25

3.4.1 - Aspectos geológicos e geomorfológicos do município de São Carlos .. 25

3.4.2 - Aspectos climáticos do município de São Carlos ............................... 25

3.5- Aspectos físicos do município de São Simão ……..................................... 26

3.5.1 - Aspectos geológicos e geomorfológicos do município de São Simão .. 26

3.5.2 - Aspectos climáticos do município de São Simão ................................ 27

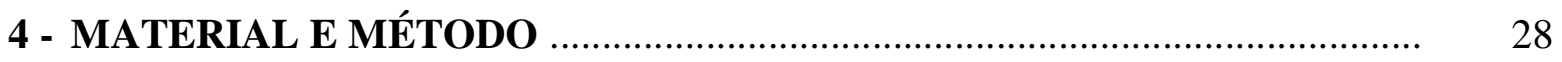

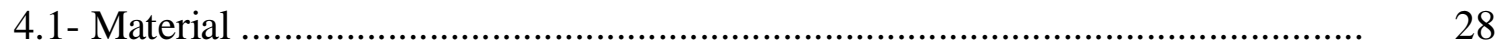

4.1.1- Dados meteorológicos de Pirassununga/SP ....................................... 28

4.1.2 - Dados meteorológicos de São Carlos/SP .............................................. 28 
4.1.3 - Dados meteorológicos de Rio Claro/SP ............................................... 29

4.1.4 - Dados meteorológicos de São Simão/SP .............................................. 29

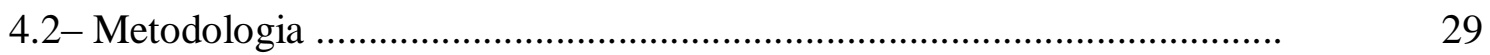

4.2.1 - Média aritmética ................................................................................ $\quad 30$

4.2.2 -Desvio padrão ............................................................................... $\quad 30$

4.2.3 - Coeficiente de variação .................................................................. 31

4.3- Análise da tendência .....................................................................................

4.3.1 - Regressão linear .................................................................... 32

4.3.2 - Testes estatísticos de Mann-Kendall e curvatura de Sen ................. 33

4.3.3 -. Estimativa das tendências .............................................................. 36

4.3.4 - Determinação da significância estatística das tendências .................. 36

4.4- Fórmulas da estatística de Mann-Kendall .................................................... 37

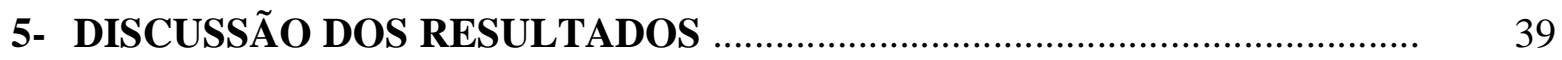

5.1- Análise dos dados de temperatura e pluviosidade da série temporal de 1976 a 2009 para Pirassununga/SP ..................................................................... 39

5.1 .1 - Análise da variabilidade da temperatura .............................................. 39

5.1.1.1- Temperatura média .................................................................... 39

5.1.1.2- Temperatura máxima …............................................................... 41

5.1.1.3- Temperatura mínima ................................................................... 43

5.1.1.4- Temperatura média máxima ............................................................ 44

5.1.1.5- Temperatura média mínima

5.1.2- Análise da tendência para as temperaturas médias, máximas, mínimas, média máxima e média mínima: retas de regressão .............. 46

5.1.3- Análise da variabilidade para a pluviosidade ........................................ 49

5.1.4- Análise da tendência para a pluviosidade: reta de regressão ................. 53

5.1.5- Análise da tendência para a temperatura e pluviosidade: teste de Mann-Kendall e curvatura de Sen 
5.1.5.1- Medidas estatísticas das temperaturas máximas, médias máximas, mínimas, médias mínimas, médias e pluviosidades em Pirassununga no período de 1976-2009

5.1.5.2- Análises das tendências e das estimativas

5.2- Análise dos dados de temperatura e pluviosidade da série temporal de 1994 a 2009 para Pirassununga/SP

5.2.1- Análise da variabilidade da temperatura

5.2.1.1- Temperatura média

5.2.1.2- Temperatura máxima

5.2.1.3- Temperatura mínima

5.2.1.4- Temperatura média máxima

5.2.1.5- Temperatura média mínima

5.2.2- Análise da tendência para as temperaturas médias, máximas, mínimas, média máxima e média mínima: retas de regressão

5.2.3- Análise da variabilidade para a pluviosidade

5.2.4- Análise da tendência para a pluviosidade: reta de regressão

5.2.5- Análise da tendência para a temperatura e pluviosidade: teste de Mann-Kendall e curvatura de Sen

5.2.5.1- Medidas estatísticas das temperaturas máximas, médias máximas, mínimas, médias mínimas, médias e pluviosidade em Pirassununga no período de 1994-2009

5.2.5.2- Análises das tendências e das estimativas

5.3- Análise dos dados de temperatura e pluviosidade da série temporal de 1994 a 2009 para Rio Claro/SP

5.3.1- Análise da variabilidade da temperatura

5.3.1.1- Temperatura média

5.3.1.2- Temperatura máxima

5.3.1.3- Temperatura mínima

5.3.1.4- Temperatura média máxima

5.3.1.5- Temperatura média mínima

5.3.2- Análise da tendência para as temperaturas médias, máximas, mínimas, média máxima e média mínima: retas de regressão 
5.3.3- Análise da variabilidade para a pluviosidade

5.3.4- Análise da tendência para a pluviosidade: reta de regressão

5.3.5- Análise da tendência para a temperatura e pluviosidade: teste de

Mann-Kendall e curvatura de Sen

5.3.5.1- Medidas estatísticas das temperaturas máximas, médias máximas, mínimas, médias mínimas, médias e pluviosidade em Rio Claro no período de 1994-2009

5.3.5.2- Análises das tendências e das estimativas

5.4- Análise dos dados de temperatura e pluviosidade da série temporal de 1994 a 2009, para São Carlos (SP)

5.4.1- Análise da variabilidade da temperatura

5.4.1.1- Temperatura média

5.4.1.2- Temperatura máxima

5.4.1.3- Temperatura mínima

5.4.1.4- Temperatura média máxima

5.4.1.5- Temperatura média mínima

5.4.2- Análise da tendência para as temperaturas médias, máximas, mínimas, média máxima e média mínima - retas de regressão

5.4.3- Análise da variabilidade para a pluviosidade

5.4.4- Análise da tendência para a pluviosidade - reta de regressão

5.4.5- Análise da tendência para a temperatura e pluviosidade - Teste de Mann-Kendall e Curvatura de Sen

5.4.5.1- Medidas estatísticas das temperaturas máximas, médias máximas, mínimas, médias mínimas, médias e pluviosidades em São Carlos no período de 1994-2009

5.4.5.2- Análises das tendências e das estimativas

5.5- Análise estatística dos dados de temperatura e pluviosidade da série temporal de 1994 a 2009 para São Simão/SP

5.5.1- Análise da variabilidade da temperatura

5.5.1.1- Temperatura média

5.5.1.2- Temperatura máxima

5.5.1.3- Temperatura mínima 
5.5.1.4- Temperatura média máxima

5.5.1.5- Temperatura média mínima

5.5.2- Análise da tendência para as temperaturas médias, máximas, mínimas, média máxima e média mínima - retas de regressão

5.5.3- Análise da variabilidade para a pluviosidade

5.5.4- Análise da tendência para a pluviosidade - reta de regressão

5.5.5- Análise da tendência para a temperatura e pluviosidade - teste de Mann-Kendall e curvatura de Sen

5.5.5.1- Medidas estatísticas das temperaturas máximas, médias máximas, mínimas, médias mínimas, médias e pluviosidade em São Simão no período de 1994-2009

5.5.5.2- Análises das tendências e das estimativas

5.6- Análise estatística dos dados de temperatura e pluviosidade da série temporal de 1994 a 2009 para Pirassununga, Rio Claro, São Carlos e São Simão: comparações entre os resultados obtidos pelo método de MannKendall e Sen 


\section{1- INTRODUÇÃO}

Uma das grandes preocupações do meio científico-acadêmico nos últimos anos evidencia as mudanças climáticas e suas consequências em relação a todas as implicações de âmbito social, ambiental e econômico. Tais preocupações em relação às alterações climáticas devem-se ao fato que, desde meados do século passado, o clima do planeta vem apresentando comportamento com variação bastante acentuada.

Segundo Christofoletti (1993), o clima pode ser considerado o elemento condicionador da dinâmica do meio ambiente, com influência direta nos processos de ordem física e biológica, assim como nos sistemas sócioeconômicos de um modo geral, constituindo-se, portanto, um recurso essencialmente importante para todas as atividades humanas.

Embora, no passado, o clima não fosse sempre idêntico e suas oscilações possibilitassem tanto o surpreendente desenvolvimento da vida no planeta, quanto a destruição decorrente de desastres e catástrofes, ainda causa perplexidade a repercussão que os elementos do clima exercem sobre nossas vidas (SANT'ANNA NETO E ZAVATTINI, 2000).

A preocupação, de certa forma exagerada e generalizada, em relação aos desastres que possivelmente podem estar vinculados às mudanças e impactos climáticos, advém do fato de existirem quase 7 bilhões de pessoas ocupando a superfície do planeta, a grande maioria em condições ambientais precárias e altamente vulneráveis às catástrofes que possam ocorrer. De acordo com Vianello e Alves (1991), Conti (1993; 2000), Lombardo (1994) e Tavares (2001), a maioria dos fatores responsáveis pelos processos de mudanças climáticas são os de ordem natural, relacionados a parâmetros orbitais da Terra, à frequência de rotação, à intensidade de radiação solar, à quantidade de poeira atmosférica, destacando-se, também, o decréscimo do índice de salinidade do Atlântico Norte, as alterações na temperatura oceânica e a complexidade do sistema interativo Terra-Oceano-Atmosfera.

Os estudos de dados climáticos, realizados nos Estados Unidos por Karl et al. (1996), mostraram que, embora a temperatura tenha apresentado tendência de crescimento nas últimas décadas, as variações não são tão grandes nem temporalmente consistentes, podendo-se levantar a hipótese que as mudanças tenham ocorrido por alterações aleatórias naturais.

As condições climáticas na Terra sofrem flutuações contínuas e, dependendo da escala de tempo com que se trabalha, é possível visualizar essa variabilidade e definir o que são mudanças climáticas (SENTELHAS et al., 2000). 
A verificação de possíveis mudanças climáticas é, para vários autores, uma tarefa considerada muito complexa, pois aborda aspectos que envolvem dificuldades como mudança nas técnicas de medidas dos atributos climatológicos, distribuição inadequada de pontos de medidas, no que se refere à instalação das estações meteorológicas, distinção entre a variabilidade natural do clima em relação a ação antrópica e dificuldades nas aplicações de métodos estatísticos de modelagem do clima.

De acordo com Oliveira (2001), o conhecimento detalhado da dinâmica climática e das interações que mantém com os demais elementos do ambiente é uma contingência necessária para toda e qualquer atividade humana. A estreita relação existente entre os aspectos climáticos e todos os setores de atividades humanas atesta a importância do conhecimento das condições climáticas para o gerenciamento dessas atividades. Segundo o autor, o aquecimento global tem implicação direta na alteração da frequência e distribuição de chuvas, podendo aumentar as ocorrências de secas e de cheias.

Assim, a importância do conhecimento da variabilidade dos elementos climáticos em nível regional e local é destacada por Bessat (2003), Nunes (2003), Paciornik (2003) como uma maneira de contribuir para a compreensão dela em nível global. A variabilidade e tendência da temperatura e precipitação, em várias regiões, do estado de São Paulo, foram estudadas por Zavattini (1983), Christofoletti (1991), Sant'Anna Neto (1995), Galina (2002), Roncato (2002), Tavares (2001) e Bieras (2006), observando-se que, em determinadas localidades, a temperatura teve um pequeno acréscimo em certos períodos e decréscimos em outros, bem como tendência de diminuição ou aumento da precipitação.

As questões referentes às mudanças climáticas em escala local, regional ou global têm atraído o interesse da comunidade científica nas últimas décadas. Mudanças no padrão diário, semanal, mensal, sazonal e/ou anual dos elementos climáticos de temperatura e pluviosidade podem afetar as mais diversas atividades humanas, principalmente, aquelas referentes à economia, ao meio ambiente e ao planejamento sistemático de tantas outras atividades.

Nesse sentido, este trabalho visa a contribuir com os estudos sobre o comportamento do clima em escala local, utilizando para isso a análise estatística, com o intuito de identificar tendências anuais da temperatura e precipitação, bem como sua variabilidade ao longo da série histórica considerada.

Diante do exposto acima, o estudo da variabilidade e tendência dos elementos climáticos precipitação e temperatura em quatro localidades do estado de São Paulo, Pirassununga, Rio Claro, São Carlos e São Simão - que constituem parte da área de treinamento de voo da Academia da Força Aérea (AFA) -, pretende confirmar a hipótese de 
que essas alterações apontam para mudanças climáticas de curto prazo em escala local, e que essas mudanças podem afetar, no futuro, o planejamento das missões de treinamento de voo na AFA.

É importante ressaltar, também, que as localidades estudadas constituem uma região importante, pois nelas se realizam as missões de treinamento de voo para a formação do oficial aviador da Força Aérea Brasileira, cujo fator limitante são justamente as ocorrências de alterações nas condições climáticas envolvendo diretamente os elementos precipitação e nevoeiro, relacionados com umidade e temperatura.

Desde o tempo em que a AFA foi instalada em Pirassununga (SP), em meados dos anos 60, verificou-se um crescente desmatamento e povoamento da região; portanto, a transformação foi significativa, mas não há estudos mais detalhados a respeito do grau das mudanças climáticas provocadas pelo uso e ocupação do solo e que mostrem as interações entre as mudanças climáticas e as transformações antropogênicas.

Estudos e avaliações sobre mudanças climáticas de curto prazo envolvendo as atividades humanas são extremamente importantes para a sociedade, visto que as mesmas fornecem informações necessárias e relevantes para o planejamento de diversos empreendimentos nas áreas onde a pesquisa se realiza. 


\section{2 - REVISÃO BIBLIOGRÁFICA}

Uma das grandes preocupações dos pesquisadores, principalmente nas duas últimas décadas, está relacionada com as alterações climáticas e seus efeitos sobre o planeta. Mas, muitos cientistas concordam que ainda é cedo para comprovar mudanças drásticas do clima global. Com a finalidade de organizar e sistematizar as informações para formar a base teórica da pesquisa três aspectos foram abordados na revisão bibliográfica: mudanças climáticas, variabilidade e tendência climática e aplicações estatísticas em climatologia.

\section{1 - Mudanças climáticas}

De acordo com a Climatologia Dinâmica, a compreensão dos fenômenos atmosféricos e de suas flutuações, seus ritmos e ciclos, que conferem ao clima as principais características no tempo e no espaço, depende do entendimento da gênese desses fenômenos. Segundo Vecchia (1997), o clima não pode ser razoavelmente compreendido, tampouco modelado, sem uma abordagem fenomenológica, com base também na observação cotidiana, sem se considerar a circulação geral da atmosfera e os fenômenos intrínsecos que presidem à sua gênese.

Além disso, cabe entender, também, as decorrências particulares em escalas, dos microclimas aos climas regionais, locais etc., que, na verdade, são modificações impostas por diferenciados fatores, entre os quais se destacam os fatores geográficos e as intervenções de caráter antrópico, quando se trata, principalmente, do espaço urbano. As condições do clima na Terra sofrem flutuações contínuas, que, dependendo da escala de tempo em que se trabalha, podem ser visualizadas, permitindo a definição do significado das mudanças climáticas (SENTELHAS et al., 2000).

As definições citadas nos trabalhos publicados sobre variações climáticas, segundo Tucci (2002), tornam-se diferentes conforme a inserção dos efeitos antrópicos na identificação da variabilidade. De acordo com o IPCC (2001), Painel Intergovernamental sobre Mudança do Clima, mudança climática está relacionada com variações temporais do clima produzidas pela ação antrópica e devido também à variabilidade natural. Já outros autores adotam, para o mesmo termo, a definição de mudanças associadas direta ou 
indiretamente a atividades humanas que alterem a variabilidade climática natural observada num determinado período (STEINKE, 2004).

Variabilidade climática é a denominação utilizada para as alterações do clima em função dos elementos naturais do planeta e suas complexas interações, que geram uma variabilidade natural do clima, de modo que, mudanças climáticas seriam as alterações na variabilidade natural do clima causadas pelas atividades humanas. Assim, é necessário identificar as alterações que vêm ocorrendo na variabilidade natural para que se possa afirmar a existência de mudança climática.

De acordo com Flohn (1977), a variabilidade climática está relacionada com a duração dela, ou seja, a expressão flutuação climática deve ser usada para os desvios de curta duração, enquanto variação climática para as mudanças observadas nas séries temporais, usando-se as médias de um período de trinta anos. A expressão mudança climática deve ficar restrita a mudanças maiores.

As definições de alguns termos usados para caracterizar modificações climáticas, foram adotadas por Goossens e Berger (1986). De acordo com eles, a concepção de mudança climática engloba todas as formas de alterações do clima de origem estatística ou de causas físicas, e flutuação climática indica toda forma de mudança ordenada regular ou não, exceto a tendência e mudança.

A evolução do comportamento atmosférico sempre diferente de um ano para outro ou de uma década para outra, mostra variações a curto, médio e longo prazo.

Conti (1993 e 2000) faz várias considerações sobre os mecanismos que produzem mudanças climáticas, enfatizando que as causas naturais, como os ciclos da atividade solar, a velocidade de rotação da Terra, as alterações na dinâmica do fluxo atmosférico e a relação entre o oceano a atmosfera e a superfície terrestre têm sido, nos últimos anos, objeto de exaustivas pesquisas com a finalidade de explicar as mudanças climáticas, pois, além dos fatores naturais, é necessário considerar também a intensa modificação ambiental sistemática que o planeta vem sofrendo pela interferência da ação humana.

Bieras (2006) faz uma citação do livro Variabilidade e Mudanças Climáticas: Implicações ambientais e sócio-econômicas, elaborado por Sant'anna Neto e Zavatini (2000), onde os autores relatam as contribuições de pesquisadores das áreas de Geografia, Geologia, Meteorologia e Agronomia, a respeito de mudança climática e suas implicações. Nesse sentido, a primeira parte do livro traz um panorama sobre as mudanças paleoclimáticas, com ênfase no período quaternário; e também o papel das mudanças climáticas e o planejamento agrícola. 
Assim, para distinção dos conceitos e denominações para diferentes modificações e alterações do clima, Conti (2000) propôs as seguintes classes de variação:

mudança climática: termo mais geral que abrange toda e qualquer manifestação de inconstância climática, independente de sua natureza estatística, escala temporal ou causas físicas;

variabilidade climática: maneira pela qual os parâmetros climáticos variam no interior de um determinado período de registro expressos através de desvio padrão ou coeficiente de variação;

tendência climática: aumento ou diminuição lenta dos valores médios da série de dados históricos de, se possível, três décadas. Essa tendência não se restringe a uma mudança linear ao longo do tempo, mas caracteriza-se apenas por um mínimo e um máximo nos pontos terminais do registro;

descontinuidade climática: remete à inconstância que consiste em mudança abrupta e permanente de um valor médio para outro, durante o período de registro;

flutuação climática: correspondente a qualquer forma de mudança sistemática, regular ou irregular, caracterizada por, pelo menos, duas máximas (ou mínimas) e uma mínima (ou máxima), observadas no período de registro;

variação climática: é uma flutuação cujas características, em escala temporal, são suficientemente longas para resultar em diferença apreciável entre médias ( ou normais) sucessivas, geralmente observada na escala de décadas;

oscilação climática: flutuação na qual a variável tende a mover-se gradual e suavemente entre máximas e mínimas sucessivas;

vacilação climática: flutuação em que a variável tende a permanecer, alternadamente, em torno de dois (ou mais) valores; e a movimentação de um valor médio para outro ocorre em intervalos regulares ou irregulares;

periodicidade climática: oscilação em que as máximas e as mínimas ocorrem em intervalos de tempo iguais, por exemplo, 26 anos.

Angelocci e Sentelhas (2007), em material didático utilizado na disciplina Meteorologia Agrícola, ministrada na ESALQ/USP - Piracicaba (SP), apresentam, didaticamente, o conceito de flutuação temporal do clima em função dos conceitos de variabilidade, anomalia e mudança climática.

Definem variabilidade climática como uma variação das condições climáticas em torno da média climatológica; anomalia climática, como uma flutuação extrema de um elemento em uma série climatologia, com desvios acentuados do padrão observado de 
variabilidade, e, mudança climática, designa uma tendência de alteração da média no tempo. Os autores ressaltam, ainda, a inexistência de uma distinção absoluta entre variabilidade e mudança climática, pois tudo depende da escala de tempo com que se trabalha.

Essas definições refletem as dificuldades para separar os efeitos da ação antrópica sobre o clima e a variabilidade natural do mesmo, sobretudo porque o sistema climático é extremamente complexo e sua dinâmica ainda não completamente compreendida.

Uma das grandes preocupações dos pesquisadores, principalmente nas duas últimas décadas, está relacionada com as alterações climáticas e seus efeitos sobre o planeta. Segundo Houghton et al. (1990), foi constatado que a temperatura média global aumentou entre 0,3 e $0,6^{\circ} \mathrm{C}$ desde o final do século passado. Nos últimos anos, vem-se mencionando a possibilidade de mudança climática como consequência da produção e emissão de gases-estufa devido a atividades humanas (BRUCE, 1990; BERLATO et al., 1995).

Vários trabalhos, como os de Houghton et al. (1990, 1992), Houghton et al. (1996) e National Research Council (1992), após discussão e análise das conseqüências do efeitoestufa no aquecimento global concluíram que as mudanças observadas no clima global ainda são insuficientes para serem atribuídas às causas antropogênicas de aumento do efeito-estufa. $\mathrm{O}$ aquecimento global tem como consequência direta a alteração na frequência e distribuição das chuvas, com aumento das ocorrências de secas e de cheias (KARL et al., 1996).

Fenômeno natural, o efeito estufa, que sempre existiu, é absolutamente necessário para a existência da vida na Terra. O Sol envia ao nosso planeta uma considerável quantidade de energia luminosa, da qual $70 \%$ são absorvidas e transformadas em calor na atmosfera, principalmente na superfície dos oceanos e das terras emersas. Os restantes 30\% correspondem à energia refletida pela Terra e pela atmosfera, principalmente pelas nuvens (MOUVIER, 1994).

Ainda de acordo com Mouvier (1994), atualmente, as concentrações, na atmosfera, dos gases responsáveis pelo efeito estufa são mais altas do que nunca; elas aumentam de forma contínua, em proporções e velocidades nunca antes observadas. $\mathrm{O}$ aumento anual é de 0,5\% para o gás carbônico $\left(\mathrm{CO}_{2}\right)$, de $0,9 \%$ para o metano $\left(\mathrm{CH}_{4}\right)$, de $0,25 \%$ para o protóxido de nitrogênio $\left(\mathrm{N}_{2} \mathrm{O}\right)$ e de $4 \%$ para os clorofluorcarbonos (CFC 11 e CFC 12). Estudos apresentados por Daí et al. (1997), sobre a variação da distribuição da precipitação na superfície do planeta, no período de 1900 a 1988, mostraram que, em grande parte, houve um aumento de precipitação; porém, em outras regiões foi registrada uma diminuição da precipitação. 
A expectativa de grandes mudanças em relação ao comportamento climático do planeta devido a efeitos antrópicos agravou-se em meados da década de 80, com o desmatamento das florestas, a redução da camada de ozônio e o agravamento do efeito estufa. Mas, de acordo com Folland et al. (2001), um aumento na temperatura média global tem proporcionado a primeira evidência de uma variação climática antropogênica, com temperaturas da superfície global variando a uma taxa de $0,15^{\circ} \mathrm{C}$ por década, desde 1970 , sendo que os dez anos mais quentes ocorreram entre 1990 e 2000.

De acordo com Paciornick e Machado Filho (2000), as concentrações humanas nos centros urbanos emitem gases responsáveis pelo efeito estufa (dióxido de carbono, metano, ozônio e óxido nitroso), formando, na atmosfera uma camada que impede o retorno para o espaço de parte da radiação térmica refletida pela superfície da Terra. Se as emissões desses gases não diminuirem, estima-se que a temperatura do planeta sofrerá uma elevação entre $0,8^{\circ} \mathrm{C}$ e $4,5^{\circ} \mathrm{C}$, em média, até o ano de 2100 . Essa elevação de temperatura poderá causar um aumento no nível dos mares entre $13 \mathrm{~cm}$ e $94 \mathrm{~cm}$.

Já é de domínio do conhecimento que as grandes concentrações de gases, como o dióxido de carbono $\left(\mathrm{CO}_{2}\right)$, do metano $\left(\mathrm{NH}_{4}\right)$ e do óxido nitroso $\left(\mathrm{N}_{2} \mathrm{O}\right)$ estão aumentando desde os primeiros anos pós Revolução Industrial, com a taxas cada vez mais elevadas, muito provavelmente pela intensificação das atividades de produção dos bens de consumo e uso de combustível fóssil.

Os aumentos das concentrações desses gases na atmosfera estão relacionados com o efeito estufa, que, por sua vez, produz o aquecimento global. Em relação ao aspecto polêmico sobre o aquecimento global, Villa Nova (2000), chama a atenção para que não se confundam as tendências climáticas com variações climáticas. Villa Nova explica que as tendências climáticas são mudanças suaves no clima, que indicam consequências a longo prazo. Já as mudanças climáticas referem-se a eventos isolados, que fogem de um padrão climático habitual. Ainda segundo Villa Nova "O principal motivo de fenômenos como El Niño e La Niña está no centro da Terra". Ele explica que, quando acontece um aquecimento das águas marítimas próximas à Ilha da Páscoa, provocado por uma fenda na crosta terrestre, que funciona como um vulcão submerso, ocorre uma alteração na pressão da região. Isso leva a corrente de ar, que antes ia de leste a oeste, a inverter seu sentido. O fato conhecido como El Niño, que traz consequências, às vezes catastróficas, como enchentes e tornados, também prejudica a pesca em muitas regiões que dependem dela para viver. Para Villa Nova " $\mathrm{O}$ aquecimento global pode aumentar a temperatura dos oceanos, mas não a ponto de desencadear determinados fenômenos". 
O ENOS, ou seja, El Niño Oscilação Sul, constitui-se um fenômeno oceânicoatmosférico com influência no clima regional e global, ao alterar a circulação geral da atmosfera. O fenômeno tem origem no setor centro-leste do Oceano Pacífico, produzindo efeitos observados em diferentes regiões do planeta. O componente atmosférico do fenômeno, denominado Oscilação Sul, expressa a relação inversa existente entre a pressão nos extremos leste e oeste do Pacífico leste.

O El Ninõ está relacionado com o aquecimento anômalo das águas superficiais do Oceano, ou seja, onde normalmente há águas mais frias, aparecem águas mais quentes do que o normal; portanto, produz um aquecimento nas águas do oceano, provocando, simultaneamente, uma diminuição na pressão atmosférica. La Niña produz, ao contrário, o resfriamento das águas e aumento na pressão atmosférica no Pacífico leste.

Tucci, 2002, acredita que o acidente nuclear de Chernobyl foi um grande divisor do processo, quando se observou que ações numa parte da Terra poderiam afetar a população de outras regiões. Na hipótese de que o aumento na quantidade de $\mathrm{CO}_{2}$ produz uma elevação da temperatura da baixa atmosfera, num modelo de escala logarítmica, vários eventos foram organizados para discutir a problemática da mudança climática global. Assim, foi implantado, em 1988, pelo PNUMA - Programa das Nações Unidas para o Meio Ambiente e pela Organização Meteorológica Mundial (OMM), o Painel Intergovernamental sobre Mudança do Clima (IPCC), com o intuito de avaliar as informações científicas existentes sobre a mudança do clima, os impactos ambientais, sociais e econômicos da mudança do clima e de estabelecer estratégias de resposta a esses impactos.

Os relatórios de avaliação do IPCC são reconhecidos no meio científico como fontes confiáveis de dados sobre as mudanças climáticas. O terceiro relatório de avaliação mostra fortes evidências de que a maior causa do aquecimento global dos últimos 50 anos se deve às atividades humanas e faz previsões para os próximos 100 anos: o aumento da média global de temperatura (entre 1,4 a 5,8 ${ }^{\circ} \mathrm{C}$ ); o aumento no nível dos mares devido à expansão térmica dos oceanos e o derretimento das calotas polares entre 0,09 e 0,88 metros. Se isso se confirmar, poderá ocorrer um aumento na incidência das ondas de calor, das secas e de grandes inundações.

Embora exista toda uma credibilidade envolvendo o IPCC, em função de nele estarem reunidos cientistas do mundo inteiro, representando diferentes áreas do conhecimento, é cada vez maior o número de cientistas que coloca em dúvida as afirmações dos Relatórios de Avaliação da instituição. 
As previsões de mudanças climáticas devidas às atividades antrópicas não estão diretamente ligadas ao efeito estufa, pois este é uma propriedade natural da atmosfera; mas, estão relacionadas com o aumento do efeito estufa, intensificado pelo lançamento dos gases na atmosfera, reforçando o bloqueio à saída da radiação infravermelha. A emissão e expansão desses gases na atmosfera, poderá implicar no aumento da temperatura, mas de acordo com Alves (2001), a adição, na atmosfera, de $\mathrm{CO}_{2}$ produzido pelas atividades humanas corresponde apenas a um "mecanismo forçante" do aquecimento, mas não garante que ele ocorrerá.

Com as atividades de urbanização, ocorre, também, um efeito denominado albedo, responsável pelo aumento da refletância do planeta, que reduz a entrada de energia solar na atmosfera, implicando um mecanismo que força o resfriamento. Se esses dois mecanismos tiverem a mesma intensidade e, por terem sentidos opostos, a temperatura global não iria se alterar.

Nesse sentido, Molion (1995) chama a atenção para o fato da existência de problemas de representatividade das séries históricas de temperatura, tornando complexa sua caracterização, e, consequentemente o cálculo de uma média confiável para o planeta. Ele ressalta, também, que não é possível concluir se houve um aumento de $0,5^{\circ} \mathrm{C}$ na temperatura média do ar nos últimos 150 anos e, mesmo que o aquecimento tivesse acontecido, a maior parte dele ocorreu antes de 1950, nessa época a liberação de carbono era em torno de $30 \%$ menor do que nos dias atuais.

Ainda em relação aos conceitos e definições utilizados para caracterizar dados climatológicos, Kim et al. (2001) realizaram um estudo de climatologia diária da temperatura mínima, da máxima e da chuva acumulada, utilizando a aplicação do "Model Output Statistics" (MOS) para a previsão de curto prazo no Estado do Paraná. Eles relataram que os resultados da avaliação das previsões obtidas por meio do MOS foram comparadas com as previsões de persistência e climatologia.

A previsão de persistência significa a utilização da situação de hoje para previsões dos próximos dias; e a previsão de climatologia significa a utilização das normais climáticas diárias para previsões dos dias correspondentes. Com os resultados obtidos, os pesquisadores concluíram que as previsões de ocorrência de chuva e medidas de temperatura através do MOS têm vantagem diante das previsões de persistência e da climatologia. 


\section{2 - Variabilidade e tendência climática}

\subsection{1 - Variabilidade climática}

Os valores observados e medidos dos elementos que compõem o clima não são constantes no tempo e no espaço. Ao longo de tempo, e a cada instante, ocorrem variações nesses valores e nas interações entre eles, estabelecendo-se múltiplas probabilidades, definidas pelas funções de distribuição.

Além da variabilidade associada a movimentos astronômicos como translação e rotação da Terra, aproximadamente periódicos, o clima apresenta uma variabilidade natural, não periódica, complexa, que determina as diferenças entre ocorrências de um determinado ano e as dos anos anteriores e dos seguintes. O sistema climático é extremamente complexo, em função de variáveis intervenientes, interações dinâmicas e processos de interação entre as escalas.

O fato de ainda não se ter um claro entendimento sobre as interações conduz às falhas nas previsões de longo prazo, contribuindo, também, para isso, o fato de as ferramentas de análise para a compreensão da variabilidade climática serem ainda deficientes no tratamento de aspectos dinâmicos do clima.

O estágio do atual conhecimento científico sobre o clima justifica as preocupações que induzem a elaboração de mais pesquisas e estudos sobre a variabilidade climática, já que há implicações do fenômeno nas áreas econômicas, sociais e ambientais do planeta.

Na literatura específica, a denominação variabilidade climática está associada com as alterações do clima em função das condicões naturais do planeta e suas interações, portanto, chamada variabilidade climática natural. Já as "mudanças climáticas" são consideradas como alterações na variabilidade climática natural como consequência das atividades humanas.

A principal causa da variabilidade climática em diversas regiões da Terra é atribuída ao ENOS - El Niño Oscilação Sul, fenômeno de interação oceano-atmosfera que tem origem no Oceano Pacífico tropical. Esse fenômeno, que em geral apresenta um padrão coerente de persistência, de 12 a 18 meses, interfere na circulação atmosférica em escala regional e global, produzindo impactos e alterações no clima de várias e extensas regiões do Globo.

Parker e Folland (1988), admitiram que a variabilidade climática não depende somente da complexa dinâmica atmosférica e de seus processos de troca com os oceanos e a biosfera, 
mas também da intervenção antrópica, gerando poluição, e de agentes externos, como os ciclos solares e as erupções vulcânicas.

Pinto et al. (1989), analisando os atributos climáticos pluviosidade e temperatura, em séries meteorológicas do Brasil, verificaram que podem ocorrer variações contínuas ou ciclos bem caracterizados, de acordo com a região estudada.

Nunes e Lombardo (1995), após a conclusão de um trabalho de revisão da literatura sobre a questão da variabilidade climática, observaram que o tratamento dado à questão da variabilidade climática atesta não haver consenso entre cientistas voltados às ciências atmosféricas, pois, de um lado há os que acreditam apenas na consideração do ambiente global para levar a uma compreensão do tema; por outro lado, os críticos desses estudos alegam que, graças à escala em que são elaborados, esses modelos negligenciam feições locais, dificultando a relação entre climas globais, regionais e locais.

O consenso mais aceitável entre os pesquisadores é o fato de que a ciência descobriu que o clima do planeta tem uma variabilidade natural, independente da presença humana e de suas atividades. Mesmo se o ser humano não habitasse o planeta, ou fosse extinto por uma causa incontrolável, os movimentos do planeta e a dinâmica atmosférica continuariam produzindo as mesmas estações do ano, com as mesmas características climáticas, ou seja, não teriam sempre a mesma temperatura, o mesmo volume e distribuição de chuvas e assim por diante, pois isso se deve a fatores externos como o movimento de translação que determina o afastamento e a aproximação entre o Sol e a Terra, alterando a intensidade da radiação solar e produzindo aquecimento ou resfriamento em todo o sistema atmosférico.

Segundo Conti (2000), variabilidade climática é a forma pela qual os atributos climáticos variam ao longo de um determinado período de registro, expressos através de desvio padrão ou coeficiente de variação.

De acordo com Tucci (2002), variabilidade climática são as variações que o clima sofre em função das condicões naturais do planeta e de suas interações, e modificações climáticas são as alterações da variabilidade climática provenientes das atividades humanas.

A World Meteorological Organization - Organização Meteorológica Mundial (WMO, 2006) - define variabilidade climática como maneira pela qual os atributos climáticos variam ao longo de um determinado período de registro, expressos por meio do desvio-padrão ou coeficiente de variação.

Angelocci e Sentelhas (2010) definem variabilidade climática como uma variação das condições climáticas em torno da média climatológica. 
Sendo assim, torna-se necessário verificar se está ocorrendo modificações na variabilidade natural para se afirmar a existência de mudança climática.

\subsection{2 - Tendência climática}

Os trabalhos científicos publicados no final do século XX, e mais acentuadamente no início do século XXI, têm mostrado a grande preocupação em pesquisar a presença da tendência climática, de elementos meteorológicos, principalmente temperatura e precipitação, tanto em escala local, como em regional e global.

Nesse sentido, os pesquisadores Back (2001), Anunciação (2001), Galina (2002, Tavares (2002), Peterson et al. (2002), Frich et al. (2002), Vincent et al. (2005), Bieras e Santos (2006), Alexander et al. (2006), Folhes e Fisch (2006), Kuintchner (2006), Dantas et al. (2007, Winke et al. (2008), Campos e Ruivo (2009), Cordeiro (2010), Minuzzi et al. (2010) e Fechine e Galvìncio (2010) vêm observando e analisando as tendências em série climáticas e apontando sua significância.

Yevjevich (1972) define tendência em uma série temporal como uma modificação metódica, sistematizada e contínua em qualquer parâmetro de uma determinada série de dados, tomada como amostra, excluindo-se mudanças periódicas ou quase periódicas. Oscilação climática significa a flutuação na qual a variável tende a mover-se de forma gradual, contínua e suave entre sucessivos máximos e mínimos. A tendência climática pode constituir-se de uma mudança climática caracterizada por um leve aumento ou diminuição dos valores médios no período de registro.

Goossens e Berger (1986) estabelecem o conceito de tendência climática, como uma mudança climática constituída por um nível suave de acréscimo ou de decréscimo nos valores médios no período de registro.

De acordo com Conti (2000), a tendência climática está relacionada com a variação lenta dos valores médios da série de dados históricos de, se possível, três décadas. Essa tendência não se restringe a uma mudança linear ao longo do tempo, mas caracteriza-se apenas por um mínimo e um máximo nos pontos terminais do registro.

Villa Nova (2000), chama a atenção para que não se confundam as tendências climáticas com variações climáticas. Ele explica que as tendências climáticas são mudanças 
suaves no clima, que indicam consequências a longo prazo. Já as variações climáticas referem-se a eventos isolados que fogem de um padrão climático habitual.

Para Blain (2009), a tendência climática se caracteriza por um aumento ou uma diminuição suave (smooth) e monótona nos valores médios de uma série meteorológica. Não fica, necessariamente, restrita a tendências lineares em função do tempo, mas deve conter apenas um máximo ou um mínimo no ponto final da série. Segundo esse mesmo autor, variações climáticas se reporta à flutuação climática ou prte dela em escala de tempo suficientemente longa, capaz de resultar em variações nos parâmetros estatísticos relativos a períodos sucessivos de no mínimo 30 anos da variável meteorológica em estudo.

Frei e Schar (2000), afirmam que analisar tendências em séries meteorológicas longas, corre-se o rsco de confrontar-se com uma dificuldade fundamental, ou seja, as variações estocásticas limitam a acurácia com a qual possíveis alterações possam ser detectadas. Dessa forma, torna-se muito importante analisar também possíveis variações e tendências climáticas considerando testes não paramétricos.

A World Meteorological Organization - Organização Meteorológica Mundial (WMO, 2006) - com o objetivo de padronizar a terminologia utilizada pelas ciências da atmosfera,

entre as quais a climatologia, em relação às definições utilizadas para caracterizar mudanças climáticas, propôs a conceituação para tendência climática como o aumento ou diminuição lenta dos valores médios ao longo de uma série de dados de, no mínimo, três décadas (Normal Climatológica), podendo ou não ocorrer de forma linear.

\section{3 - Aplicações estatísticas em climatologia}

De acordo com Vianello e Alves (1991), para caracterizar o clima de uma localidade ou região, é necessário analisar os dados registrados durante um longo período, no mínimo 30 anos, uma vez que, embora tempo e clima estejam relacionados, não são, de forma nenhuma, sinônimos. O tempo meteorológico varia muito e constitui-se da soma total das condições atmosféricas de um dado local, num determinado tempo cronológico. O clima é uma integração das condições do tempo em um dado período, em uma determinada área.

Segundo Sugahara (1999), o Comitê Meteorológico Internacional definiu, em 1872, períodos de 30 anos como padrão para o cálculo das médias dos dados meteorológicos, com o objetivo de assegurar a comparação entre os dados coletados nas diversas partes do planeta. $\mathrm{O}$ 
primeiro período iniciou-se em $1^{\circ}$ de janeiro de 1901 e vai até 31 de dezembro de 1930; o segundo, em $1^{\circ}$ de janeiro de 1931 até 31 de dezembro de 1960 e assim por diante. As médias consideradas no período de 30 anos são chamadas Normais Climatológicas e consideradas referências para todas as atividades que envolvam variáveis atmosféricas.

As Normais Climatológicas são usadas normalmente como base para a comparação com as análises de dados meteorológicos com o objetivo de identificar variações e tendências ao longo dos anos ou de uma dada série histórica. A avaliação é realizada, geralmente pela comparação da média anual dos dados com o valor da Normal para o período estudado. Vários autores como Swart e Santos (2001), Tavares (2002), Ribeiro e Silva (2004) e Dantas et al. (2007) utilizaram a metodologia de análise e comparação na identificação de possíveis alterações climáticas em suas áreas de estudo.

Para Back (2001), a identificação de alterações nos registros meteorológicos é extremamente importante para a pesquisa em engenharia que utilizam as séries temporais, pois, tanto as simulações como as aplicações de teorias de probabilidade se basearam na hipótese de que as séries históricas são homogêneas, isto é, não apresentam tendências. Uma série é considerada homogênea quando os dados vêm da mesma população, de modo que não há alteração nos parâmetros.

Back (2001), com os dados obtidos da estação meteorológica de Urussanga (SC), para a série histórica de 1924 a 1998 de pluviosidade e temperatura média, empregou a análise de regressão e os testes paramétricos de Run, Mann-Kendall e Pettitt, com resultados que indicaram uma tendência significativa de aumento da temperatura média anual e da temperatura média do mês de janeiro, no ano de 1965.

Anunciação (2001), com o objetivo de definir as características da estrutura urbana da cidade de Campo Grande (MTS) e chegar às especificidades climáticas locais utilizou uma série temporal de 38 anos para avaliar a variabilidade dos parâmetros temperatura do ar, umidade relativa, pressão e vento. Os resultados obtidos permitiram constatar a importância da arborização de ruas e fundos de quintais para o conforto térmico e para a melhora das condições gerais do ambiente.

Em relação às análises de séries temporais, Galina (2002), ao estudar a tendência dos regimes térmicos e hídricos nos municípios de Ribeirão Preto, Campinas e Presidente Prudente (SP), no período de 1969-2001, constatou a tendência de aumento na temperatura média anual em $0,4^{\circ} \mathrm{C}$ em Campinas, $0,5^{\circ} \mathrm{C}$ em Ribeirão Preto e um resultado mais crítico, $1,1^{\circ} \mathrm{C}$ em Presidente Prudente. Para a realização desses estudos, foram empregados dados meteorológicos (precipitação e temperatura média) decendiais, mensais e anuais, coletados 
junto às estações climatológicas de primeira classe nos municípios em análise com aplicação do método de regressão (mínimos quadrados).

Frich et al. (2002) e Alexander et al. (2006), indicaram uma tendência de aumento da frequência de noites quentes, redução da amplitude de temperaturas máximas e redução do números de dias com geadas intensas, em escala global.

Vincent et al. (2005), por meio de análises de tendências da temperatura e Haylock et al. (2006), estudando índices anuais de precipitação, na América do Sul, apontaram para um aumento da temperatura mínima e de noites quentes, redução de noites frias e da amplitude térmica, redução de períodos secos e aumento do número de dias com intensa precipitação.

Visando a contribuir com os estudos sobre mudanças climáticas de curto prazo em escala local, Bieras e Santos (2006), analisaram a variabilidade e a tendência da precipitação pluviométrica, anual e mensal, no município de Bebedouro (SP), no período de 1983 a 2003. Para isso, utilizaram-se dos cálculos de desvio padrão e do coeficiente de variação na análise da variabilidade, e da regressão linear baseada no método dos mínimos quadrados na análise da tendência. Os resultados obtidos pelos autores mostraram uma nítida redução nos valores dessa variável durante a segunda metade da série temporal (1993 a 2003) em relação à primeira (1983 a 1992), sendo essa redução verificada tanto para os totais anuais, como para os de nível mensal. A variabilidade da chuva apresentou-se bastante significativa, tanto em nível anual como em todos os meses do ano, com os maiores valores durante o inverno. Assim, pode-se verificar que o inverno é o período do ano em que se observa maior variação no comportamento da precipitação pluviométrica no município de Bebedouro.

Folhes e Fisch (2006), apresentaram as principais características da distribuição temporal da precipitação e da temperatura em Taubaté (SP), além de estabelecerem uma caracterização do período da estação chuvosa e verificarem a ocorrência de tendências nas séries temporais desses dois elementos climáticos, por meio do teste não-paramétrico de Mann-Kendall. As análises da série temporal entre 1983 e 2005 mostraram tendência de aumento das chuvas do mês de novembro, redução em abril e diminuição do número de dias por ano sem precipitação. Quanto à temperatura, verificaram que não ocorreu tendência significativa.

Kuinchtner (2006), estudando a variabilidade da temperatura atmosférica superficial no Planalto Meridional Riograndense, pelo exame de séries temporais compostas a partir dos dados de cinco estações meteorológicas, identificou a tendência de aumento da temperatura mínima média anual $\left(0,02^{\circ} \mathrm{C} / \mathrm{ano}\right)$. Verificou também que a amplitude média anual da temperatura apresentou decréscimo na tendência $\left(-0,02^{\circ} \mathrm{C} / \mathrm{ano}\right)$. A análise das séries 
temporais, mediante a aplicação da metodologia de regressão linear dos mínimos quadrados, possibilitou a determinação de tendências e análise espectral, que por sua vez, apresentou um controle importante do fenômeno El Niño e do ciclo solar, permitindo à autora concluir, também, que os fenômenos naturais ainda predominam como controles de variabilidade da temperatura atmosférica superficial do Planalto Meridional Riograndense.

O Relatório número quatro do Ministério do Meio Ambiente sobre Tendência das Variações Climáticas para o Brasil no Século XX e Balanços Hídricos para Cenários Climáticos para o Século XXI, elaborado por Salati et al. (2007), concluiu que a análise de dados de temperatura do período de 1991 a 2004, indicou um aumento quando comparados com os dados do período de 1961 a 1990 para todas as regiões (Norte, Nordeste, CentroOeste, Sudeste e Sul). Quanto às precipitações, existe uma grande variabilidade nas mesmas regiões, sendo o maior aumento na região Sul, com 17,8 \%; e a maior diminuição, na região Nordeste, com $11,6 \%$.

Para avaliar a tendência de dados climáticos em uma série de quatorze anos (1991 a 2004), na região de Lavras (MG), comparando com dados da série histórica do período de 1961-1990 (Normal climatológica), Dantas et al. (2007), utilizando-se do método do balanço hídrico, concluíram que houve uma mudança na série mais recente, em que as temperaturas médias mensais aumentaram e os totais mensais de precipitação na série mais recente diminuíram.

Para identificar possíveis tendências climáticas por trimestre em séries de precipitação pluviométricas, utilizando a série temporal de 1975 a 2005, em Araguari (MG), e, aplicando o teste não-paramétrico de Mann-Kendall, Rodrigues e Santos (2007) identificaram uma tendência não significativa no primeiro trimestre. Para o segundo, terceiro e quarto trimestres houve uma tendência negativa.

Galina et al. (2007), no artigo Mudanças Climáticas de Curto Prazo: Análise da Variabilidade Térmica e Hídrica e do Balanço Hídrico, Ribeirão Preto (SP), utilizaram dados de precipitação e temperatura decendiais, mensais e anuais, coletadas no Instituto Agronômico de Campinas (1969 -2001). Aplicando o método de regressão mínimos quadrados os autores identificaram mudanças climáticas de curto prazo na escala local no período estudado.

No Estudo de Tendências nas Séries Temporais de Temperatura e Precipitação em Pelotas (RS), Winke et al. (2008), utilizando os dados climáticos do posto meteorológico da Universidade Federal de Pelotas, no período de 1931 a 2007, concluíram que ocorreu tendência para crescimento das temperaturas mínima médias anuais e que, para os outros 
parâmetros, não houve tendência significativa. Para a análise das tendências foi utilizado o teste não-paramétrico de Mann-Kendall.

Campos e Ruivo (2009) aplicaram a análise estatística para identificar tendências climáticas para a cidade de Corumbá (MGS). Para isso, foram utilizados dados mensais de temperatura (média, mínima e máxima), umidade relativa e precipitação da estação meteorológica de Corumbá, pertencente ao Instituto Nacional de Meteorologia, no período de 1961 a 2000. A análise estatística foi feita através do teste de Mann-Kendall, para verificar a tendência. Para estimar a magnitude dela, foi utilizado o método não-paramétrico denominado Curvatura de Sem, que assume que a tendência é linear. Os resultados mostram tendências positivas significantes para a temperatura média $\left(0.02^{\circ} \mathrm{C} /\right.$ mês $)$ e mínima $\left(0.04^{\circ} \mathrm{C} / \mathrm{mês}\right)$, umidade relativa $(0.15 \% / \mathrm{mês})$ e precipitação $(0.88 \mathrm{~mm} / \mathrm{mês})$. Para a temperatura máxima, a tendência não foi significativa.

Para Blain et al. (2009), a aplicação do teste não-paramétrico de Mann-Kendall, sobre uma série temporal da temperatura mínima do ar, das seguintes localidades do estado de São Paulo: Cordeirópolis/Limeira, Monte Alegre do Sul, Ribeirão Preto, Pindorama e Piracicaba. Ele permitiu concluir que, em apenas três das localidades, ocorreu uma tendência significativa da temperatura mínima: Campinas, Cordeirópolis/Limeira e Ribeirão Preto. Nas demais localidades não houve tendência significativa de elevação da temperatura mínima.

No trabalho, Variabilidade, Tendência, Anomalia e Mudança Climática, Sentelhas e Angelocci (2010), mostraram que é possível detectar, em um determinado período, valores crescentes (tendência crescente), como ocorreu com a chuva anual em Piracicaba (SP), entre 1933 e 1943 ou decrescente (tendência decrescente), como foi observada de 1966 a 2005, na mesma localidade. De acordo com os autores, as tendências, por ocorrerem em períodos curtos, não devem ser confundidas com mudanças do clima, pois as variáveis meteorológicas em determinado período podem, eventualmente, sofrer uma flutuação grande de um elemento em uma série climatológica, ou seja, desvio acentuado do padrão observado de variabilidade, caracterizando uma anomalia climática. Esses eventos anômalos estão normalmente associados a um fator causal, que pode ter várias origens, sendo mais comuns, atualmente, as anomalias associadas aos eventos El Niño e La Niña.

Cordeiro (2010) analisou as tendências climáticas estacionais e anuais das variáveis originais estimadas e das derivadas do balanço hídrico seriado do estado do Rio Grande do Sul, utilizando dados mensais de quatorze estações meteorológicas no período de 1950-2009. A autora utilizou o método dos mínimos quadrados e a reta de regressão para verificar a tendência da temperatura e precipitação. Os resultados mostraram que a precipitação 
apresentou forte tendência de aumento. Das temperaturas, a mínima foi, destacadamente, a que apresentou maior aumento.

No trabalho, Oscilações Climáticas em Minas Gerais, Minuzzi et al. (2010), utilizando o coeficiente angular da reta de regressão e o coeficiente do teste não-paramétrico de MannKendall, para analisar a tendências climáticas mensais da temperatura máxima, mínima, insolação e vapor de água em algumas localidade do estado de Minas Gerais, verificaram que os resultados mais relevantes indicaram crescimento da temperatura máxima e da mínima no período de $1960-2004$ (entre $1,3^{\circ} \mathrm{C}$ e $3^{\circ} \mathrm{C}$ ) e que, a maior parte do crescimento significativo da temperatura máxima, ocorreu entre setembro e dezembro.

Com o objetivo de analisar a variabilidade mensal da temperatura (máxima, mínima e média) e da precipitação no estado de Santa Catarina, em três diferentes períodos entre 1955 e 2008, Minuzzi (2010) utilizou o método da Análise de Regressão para indicar alterações climáticas e o teste não-paramétrico de Mann-Kendall, para avaliar a presença de tendências.

Os resultados obtidos apontaram para mudança no comportamento da temperatura máxima entre 1995 e 1998, e da temperatura mínima, entre 1988 e 1991. A temperatura máxima apresentou tendência de diminuição e a mínima, de aumento. Identificou, também, a inexistência de um período definido de mudança no comportamento da precipitação, com apenas um leve sinal de aumento na tendência.

Os testes de Regressão e de Kendall foram utilizados por Minuzzi e Caramori (2010), para analisar a tendência sazonal e anual da chuva no estado do Paraná. Os resultados mostraram aumento na quantidade de chuvas desde meados do século $\mathrm{XX}$, principalmente durante a primavera, e na metade leste do estado (entre 17 a $37 \mathrm{~mm} /$ década).

Fechine e Galvíncio (2010) mostraram que $87 \%$ dos postos meteorológicos apresentam tendência não significativa de queda nos índices pluviais; 6,5\% apontam para tendências negativas de queda e 55\%, com tendência significativa de aumento. O Teste não paramétrico de Mann-Kendall foi aplicado para a análise da variabilidade temporal dos dados anuais de precipitação de quinze postos meteorológicos localizados na Bacia Hidrográfica do Rio Pontal.

As formas de análise do clima urbano se apóiam na utilização de dados meteorológicos oficiais e no emprego de mini-abrigos termométricos móveis, pluviômetros, anemômetros e de equipamentos para coleta de material particulado, distribuídos em rede na área de estudo. A maioria das referências bibliográficas relacionadas a essa temática mencionam esses procedimentos. 
Um levantamento efetuado por Mendonça (2003), sobre estudos do clima urbano, realizados nos últimos trinta anos no Brasil, verificou que, de maneira geral, os dados têm sido provenientes tanto de estações fixas, quanto móveis, distribuídas em pontos préestabelecidos. A partir da década de 1990, começaram a ser empregadas mini-estações meteorológicas automáticas, além de sensores eletrônicos e imagens de satélite para aferição dos componentes da atmosfera.

Verificou-se, também, a ocorrência de maior precisão na elaboração da cartografia de representação dos parâmetros climáticos, a partir do emprego de softwares diversificados, o que garante melhor qualidade na estética e estatística para a ilustração dos episódios estudados. Assim, o estudo e análise de séries climáticas, para a verificação de tendências, encontra-se muito bem fundamentado, de acordo com a revisão bibliográfica realizada. 


\section{3 - ÁREA DE ESTUDO}

A área de estudo abordada nesta pesquisa é constituída de um polígono formado por quatro localidades, no estado de São Paulo: Pirassununga, Rio Claro, São Carlos e São Simão. A região foi escolhida por fazer parte da área de treinamento de voo realizado pelos cadetes da Academia da Força Aérea, localizada no município de Pirassununga (SP), e também por ser importante região agrícola e industrial dessa parte do estado. A figura 1 a seguir mostra a localização da área de estudo no contexto do Estado de São Paulo.

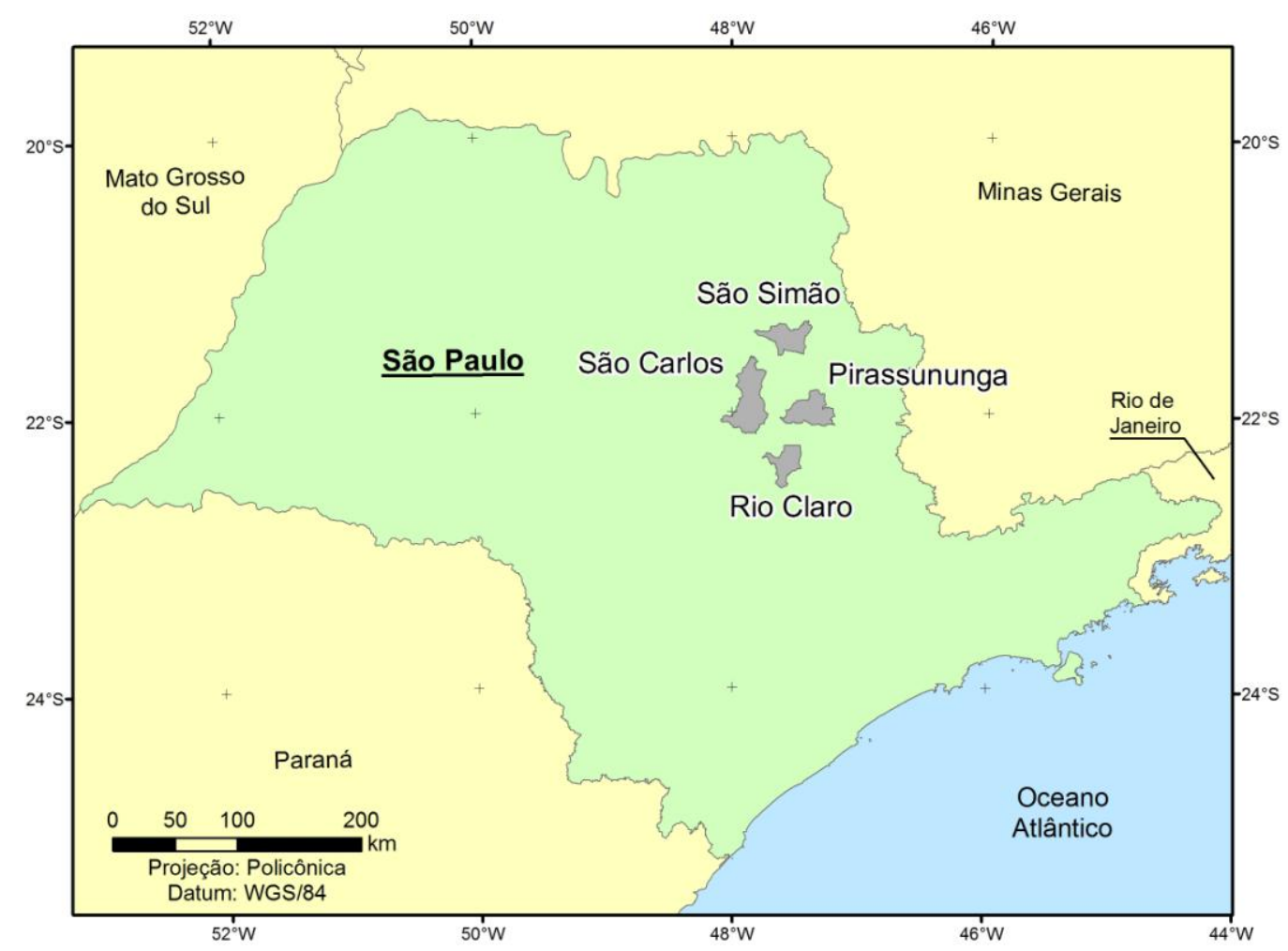

Figura 1 - Mapa da localização da área de estudo. Elaborado por Vidotti, 2012.

\section{1 - Caracterização física dos municípios de Pirassununga, Rio Claro, São Carlos e São} Simão.

O conhecimento e a descrição dos aspectos físicos da área de estudo permitem visualizar e compreender a relação existente entre o tipo de clima e suas interferências sobre o meio em que está atuando. 


\section{2- Aspectos físicos do município de Pirassununga}

A região de Pirassununga pertence à bacia hidrográfica do Rio Mogi Guaçu, com área de $17460 \mathrm{~km}$, dos quais $14653 \mathrm{~km}$ localizados na porção nordeste do Estado de São Paulo, tendo formato mais ou menos retangular estendendo-se no sentido sudoeste-noroeste do Estado de São Paulo. O rio nasce no morro do Curvado no município sul-mineiro de Bom Retiro, numa altitude de aproximadamente de $1510 \mathrm{~m}$, localizado entre as coordenadas $22^{\circ} 30^{\prime} \mathrm{S}$ e $46^{\circ} 08^{\prime} \mathrm{W}$. Após percorrer longitudinalmente aproximadamente $530 \mathrm{~km}$, deságua no Rio Pardo, $483 \mathrm{~m}$ acima do nível do mar, entre as coordenadas $20^{\circ} 53$ 'S e $4811^{\text {'W }} \mathrm{W}$, no NE do Estado de São Paulo (ZANCOPÉ e PEREZ FILHO, 2006) (Apud COLABONE, 2011).

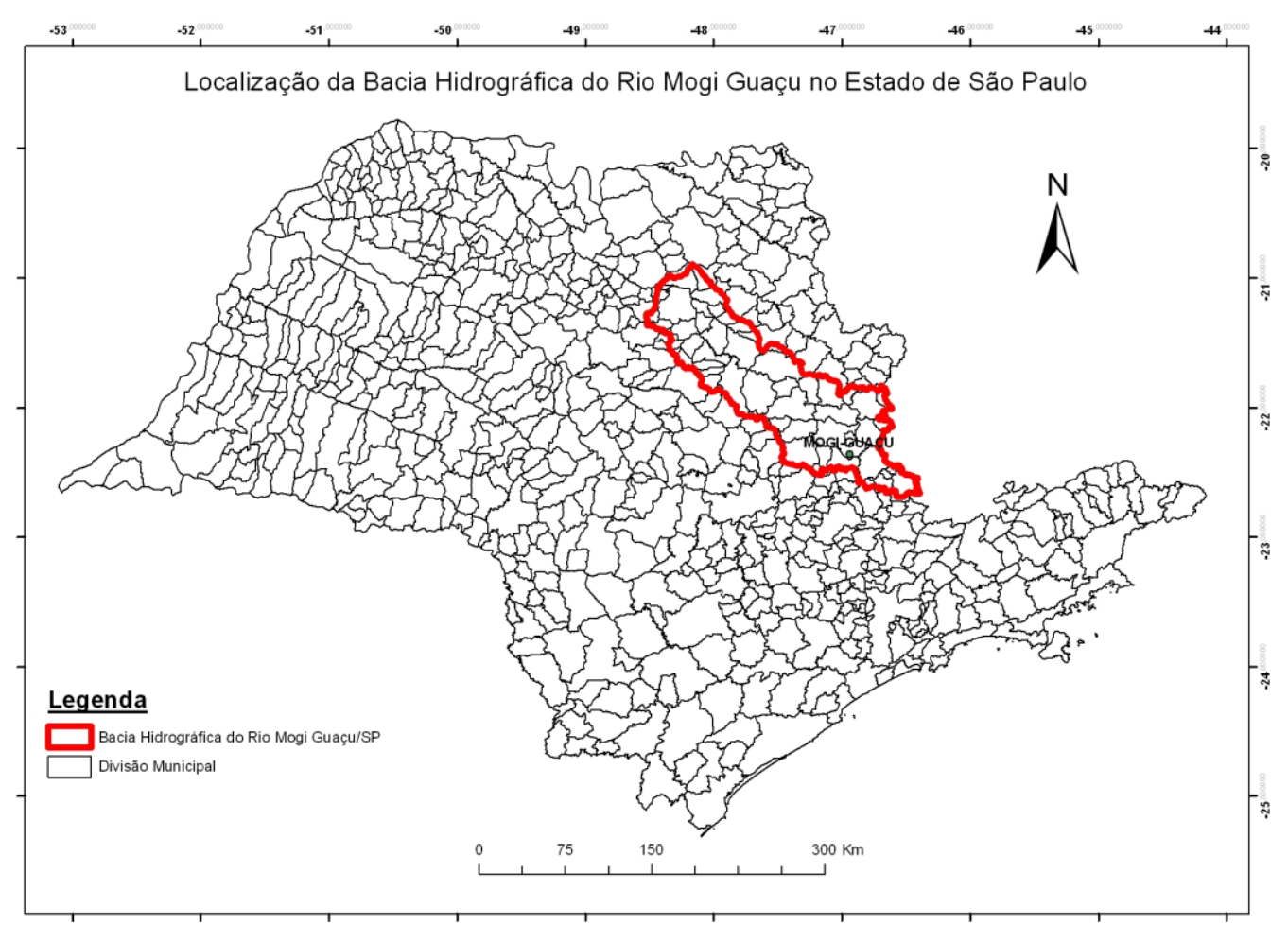

Figura 1 - Localização da bacia hidrográfica do rio Mogi-Guaçu. Fonte: Storani, 2010.

\subsection{1 - Aspectos geológicos e geomorfológicos do município de Pirassununga}

A região de Pirassununga, onde se localiza a AFA, está situada na Depressão Periférica da Zona do Médio Mogi Guaçu, com a forma de um corredor de topografia colinosa, de aproximadamente $50 \mathrm{~km}$ de largura, nitidamente embutido entre as Cuestas 
Basálticas e as elevações cristalinas do acidentado Planalto Atlântico (Ross \& Moroz, 1997), onde a Zona do Mogi é coberta por uma rede de drenagem bastante organizada. No geral, tem relevo com declividades relativamente baixas a médias (entre 6 e 12\%) e pouca variação altimétrica (entre 600 e $700 \mathrm{~m}$ de altitude). Predominam, nessa unidade geomorfológica, relevos de colinas amplas e médias (COLABONE, 2011).

As áreas de Depressão Periférica a oeste são constituídas litologicamente, na sua maior parte, por areia, o que resultou na formação de solos ácidos e pobres em fertilidade. Na área de estudo há predominância de latossolo vermelho amarelo fase arenosa (BUFON, 2002)

\subsection{2 - Aspectos climáticos do município de Pirassununga}

De acordo com Colabone (2011), a região tem, segundo o sistema internacional de Köppen, clima do tipo CWa, que se caracteriza por ser mesotérmico de inverno seco, com temperatura média do mês mais frio inferior a $18^{\circ} \mathrm{C}$ e a do mês mais quente, ultrapassando $22^{\circ} \mathrm{C}$. O total das chuvas do mês mais seco não ultrapassa $30 \mathrm{~mm}$. $\mathrm{O}$ índice pluviométrico desse tipo climático varia entre 1100 e 1700 mm, com diminuição da precipitação de leste para oeste. A estação seca nessa região ocorre nos meses de abril a setembro, sendo julho o mês com seca mais intensa. O mês mais chuvoso fica entre janeiro e fevereiro. A temperatura do mês mais quente oscila entre 22 e $24^{\circ} \mathrm{C}$. A pluviometria média da região situa-se em torno de $1600 \mathrm{~mm} / \mathrm{ano}$. No período de novembro a fevereiro a média mensal é igual ou superior a $180 \mathrm{~mm}$; nos meses de inverno é inferior a $30 \mathrm{~mm}$. As maiores precipitações ocorrem nos meses mais quentes, concentrando-se de janeiro a março e setembro a dezembro.

\section{3 - Aspectos físicos do município de Rio Claro}

Rio Claro está localizado no centro-leste do Estado de São Paulo, nas coordenadas $22^{\circ}$ $05^{\prime}$ e $22^{\circ} 40^{\prime} \mathrm{S}, 47^{\circ} 30^{\prime}$ e $47^{\circ} 55^{\prime} \mathrm{W}$. Com uma área de $499,9 \mathrm{~km}^{2}$, faz divisa com os municípios de Corumbataí e Leme ao norte, Piracicaba ao sul, Araras e Santa Gertrudes a leste e Ipeúna e Itirapina a oeste (ALVES, 2003). 


\subsection{1 - Aspectos geológicos e geomorfológicos do município de Rio Claro}

A área está localizada na província geomorfológica da Depressão Periférica Paulista, zona do Médio Corumbataí 1 (Ponçano et al., 1981). Silva (1998), utilizando dados do levantamento pedológico semi-detalhado do Estado de São Paulo (Empresa Brasileira de Pesquisa Agropecuária - EMBRAPA, 1981), identificou e mapeou os solos de ocorrência na área de estudo como latossolo vermelho amarelo e podzólico vermelho amarelo. Na região da Área de Preservação Ambiental - APA de Corumbataí, onde o município de Rio Claro está parcialmente inserido, predomina o relevo das cuestas (Pagano et al., 1989). Na face leste das cuestas há predomínio de florestas estacionais decíduas, na face oeste, predomínio de cerrados com encraves de matas ciliares, existindo, ainda, florestas estacionais semideciduais em áreas descontínuas, no geral onde ocorrem solos mais férteis (Pagano et al., 1989).

\subsection{2 - Aspectos climáticos do município de Rio Claro}

O clima da região de Rio Claro pode ser considerado tropical, com duas estações definidas - Cwa na classificação de Koeppen, ou seja, w: seca no inverno, a: mês mais quente com temperatura superior a $22^{\circ} \mathrm{C}$, ou tropical alternadamente seco e úmido, controlado por massas tropicais e equatoriais, que predominam em mais de $50 \%$ do ano, caracterizado por estiagem de inverno de junho a setembro e chuvas de verão de dezembro a março (MONTEIRO, 1973). A temperatura média do mês mais frio varia entre $2,4^{\circ} \mathrm{C}$ e $17,1^{\circ} \mathrm{C}$, as temperaturas médias anuais situam-se entre $18,1^{\circ} \mathrm{C}$ e $20,9^{\circ} \mathrm{C}$ (TROPPMAIR, 1992).Os ventos dominantes provêm dos quadrantes S e SE. Quanto à distribuição anual do regime das chuvas, ocorre um período seco entre abril e setembro, com 15 a 20 dias de chuva, e um período chuvoso, de outubro a março, com 55 a 60 dias de chuva, respondendo por mais de $80 \%$ das precipitações anuais. A média para Rio Claro é da ordem de 1.400 mm/ano. 


\section{4 - Aspectos físicos do município de São Carlos}

O município de São Carlos está estrategicamente localizado no centro geográfico do Estado de São Paulo, tendo como coordenadas geográficas 220104" (latitude sul) e 4753`27" (longitude oeste), com uma altitude média de 856 metros em relação ao nível do mar com área de $1.141 \mathrm{~km}^{2}$.

\subsection{1 - Aspectos geológicos e geomorfológicos do município de São Carlos}

Segundo Ross e Moroz (1997), o município de São Carlos, situa-se no Planalto Residual de São Carlos, localizado no interfluvio Tietê/Mogi-Guaçu, com altitudes variando entre 600 a 900 m, com vertentes de baixa declividade, entre 2 e 20\%, atingindo $30 \%$ apenas nas porções de relevo mais dissecados. As formas de relevo são denudacionais, formadas por colinas de topos convexos e tabulares.

A classe de solos predominante é a de latossolo roxo, vermelho escuro e vermelho amarelo. Outros tipos de solos presente na região são os podzólicos vermelho amarelo, terra roxa estruturada, areia quartzosa e litossolos (MIRANDA, 2005).

\subsection{2 - Aspectos climáticos do município de São Carlos}

O município de São Carlos localiza-se na zona considerada tropical de altitude, no domínio de clima Cwa da classificação internacional de Köppen, é caracterizada por clima quente com inverno seco, no qual a temperatura média do mês mais frio é inferior a $18^{\circ} \mathrm{C}$ e a do mês mais quente ultrapassa $22^{\circ} \mathrm{C}$ (MIRANDA, 2005). Ainda segundo Miranda (2005), já ocorreram temperaturas extremas com máximas de aproximadamente $36^{\circ} \mathrm{C}$ e mínimas de $0,3^{\circ} \mathrm{C}$, com médias diárias variando de $5,5^{\circ} \mathrm{C}$ a $28^{\circ} \mathrm{C}$, as médias mensais de 17,3 a $23,6^{\circ} \mathrm{C}$ e as médias anuais, entre 20,8 e $21,7^{\circ} \mathrm{C}$.

Avaliando a pluviosidade, Miranda (2005) verificou que, no mês mais seco, o total de chuvas não atinge $30 \mathrm{~mm}$ e, no mais chuvoso, atinge valores variando entre 300 e $400 \mathrm{~mm}$. O período seco se estende de junho a agosto, com variações de junho a novembro quando o 
déficit hídrico é maior, ou de abril a setembro, quando é menor. A pluviosidade máxima mensal é de $470 \mathrm{~mm}$, com até 26 dias de chuva e máxima diária de $104 \mathrm{~mm}$, com acúmulo anual variando de 1138 a $1593 \mathrm{~mm}$ no período de outubro a março.

\section{5 - Aspectos físicos do município de São Simão}

O Município de São Simão, SP, tem coordenadas geográficas de $21^{\circ} 29^{\prime}$ de latitude sul e $47^{\circ} 33^{\prime}$ de longitude oeste, a uma altitude média de 640 metros e está localizado no nordeste do Estado de São Paulo. Faz parte da região administrativa de Ribeirão Preto, especificamente na área conhecida como Alta Mogiana. Tem cerca de $629 \mathrm{~km}^{2}$, com área urbana de aproximadamente $5,758 \mathrm{~km}^{2}$ (LIMA, 1988).

\subsection{1 - Aspectos geológicos e geomorfológicos do município de São Simão}

O Planalto Ocidental Paulista foi divido por Ross e Moroz (1997), em seis unidades geomorfológicas distintas: Planalto Centro Ocidental, Patamares Estruturais de Ribeirão Preto, Planaltos Residuais de Franca/Batatais, Planalto Residual de São Carlos, Planalto Residual de Botucatu e Planalto Residual de Marilia.

O município de São Simão está inserido na unidade geomorfológica denominada Patamares Estruturais de Ribeirão Preto, situada no interflúvio Mogi-Pardo com formas de relevo denudacionais, constituídas basicamente por colinas amplas e baixas, com topos tabulares. As altitudes variam entre 500 e $700 \mathrm{~m}$ e as declividades médias entre $2 \%$ e $10 \%$. Essa unidade de relevo é constituída litologicamente por basaltos, com solos do tipo latossolo roxo nos terrenos mais aplanados e terra roxa estruturada nas vertentes mais inclinadas (INVERNIZZI, 2001). 


\subsection{2 - Aspectos climáticos do município de São Simão}

O clima, segundo a classificação de Koppen, é do tipo Cwa, com precipitação média anual de $1400 \mathrm{~mm}$, distribuídos, estacionalmente, com $1200 \mathrm{~mm}$ no verão chuvoso (outubro a março) e $200 \mathrm{~mm}$ no inverno seco. A precipitação média mensal do mês mais seco é inferior a $30 \mathrm{~mm}$. A temperatura média anual é de $22^{\circ} \mathrm{C}$, sendo a do mês mais frio inferior a $18^{\circ} \mathrm{C}$. O balanço hídrico de Thornthwaite para o município de São Simão acusa a ocorrência de um período com ligeiro déficit hídrico $(52 \mathrm{~mm})$ nos meses de junho a setembro. A despeito disso, observa-se, que o excedente hídrico anual é cerca de 7,5 vezes o valor do déficit hídrico. Outro aspecto de interesse a ser comentado refere-se à concentração das chuvas no verão, com os meses de dezembro e janeiro apresentando valores superiores a $250 \mathrm{~mm}$, quando é normal a ocorrência de chuvas pesadas, de alta erosividade (LIMA, 1988). 


\section{4 - MATERIAL E MÉTODOS}

\section{1 - Material}

\subsection{1 - Dados meteorológicos de Pirassununga/SP}

Para a análise das condições climáticas com a finalidade de se conhecer a variabilidade e a tendência da temperatura e da precipitação no município de Pirassununga SP, foram utilizados, primeiramente, os dados mensais e anuais de temperatura e precipitação, de uma série temporal de 34 anos (1976 a 2009) e, depois, de uma série mais curta, de 16 anos (1994 a 2009), fornecidos em planilha eletrônica pelo Instituto de Controle do Espaço Aéreo ICEA - de São José dos Campos/SP, órgão responsável pelo banco de dados meteorológicos da Aeronáutica. Esses dados foram registrados pela estação meteorológica localizada no aeródromo da AFA - Academia da Força Aérea de Pirassununga- SP (Latitude $21^{0} 59^{\prime} 07^{\prime \prime S}$ Longitude $47^{0} 20^{\prime} 06^{\prime} \mathrm{W}$ - Altitude $600 \mathrm{~m}$ ). Quanto aos dados de precipitação, houve necessidade de se fazer o levantamento diretamente do formulário IEPV 105-78, no ICEA, em São José dos Campos/SP. Consultaram-se 7305 formulários para obtenção do total acumulado (24h) de chuva no aeródromo da AFA para o período analisado.

\subsection{2 - Dados meteorológicos de São Carlos/SP}

Para a análise das condições climáticas de São Carlos - SP, foram utilizados os dados mensais e anuais de temperatura e precipitação, de uma série temporal de 16 anos (1994 a 2009), fornecidos pela estação meteorológica de São Carlos, CRHEA - USP - Prefeitura Municipal de São Carlos - Prefixo: VILLE PARIS de (Latitude $22^{\circ} 01$ ' 22', S - Longitude $43^{\circ} 57^{\prime} 38^{\prime}$ ' W - Altitude $\left.733 \mathrm{~m}\right)$. 


\subsection{3 - Dados meteorológicos de Rio Claro/SP}

Para a análise das condições climáticas de Rio Claro - SP, foram utilizados os dados mensais e anuais, de uma série temporal de 16 anos (1994 a 2009), fornecidos pela estação meteorológica de Rio Claro - CEAPLA - IGCE - UNESP - Prefeitura Municipal de Rio Claro - Prefixo D4-112M - (Latitude 22 ${ }^{\circ} 23^{\prime} \mathrm{S}$ - Longitude $47^{\circ} 32^{\prime} \mathrm{W}$ - Altitude 626,5 m).

\subsection{4 - Dados meteorológicos de São Simão/SP}

Para a análise das condições climáticas de São Simão - SP, foram utilizados os dados mensais e anuais, de uma série temporal de 16 anos (1994 a 2009), fornecidos pela estação meteorológica do Ministério da Agricultura, Pecuária e Abastecimento - MAPA - Instituto Nacional de Meteorologia - INMET - Estação Climatológica Principal de São Simão - SP (Latitude $21^{\circ} 29^{\prime} \mathrm{S}$ - Longitude $47^{\circ} 33^{\prime} \mathrm{W}$ - Altitude 617,39 m).

Os dados mensais e anuais de precipitação, temperatura média, máxima, mínima e média das máximas e mínimas do período de janeiro de 1976 a dezembro de 2009, foram escolhidos para Pirassununga - SP, para obtenção de uma série histórica que compreende uma normal climatológica e pelo fato de a série estar completa, sem necessidade de preenchimento de falhas.

Os mesmos dados climatológicos de precipitação e temperatura para o período de janeiro de 1994 a dezembro de 2009 foram escolhidos para as localidades de São Carlos, Rio Claro, São Simão e Pirassununga, para utilização de uma mesma série histórica, sem falhas, para as quatro localidades, de modo que se possam comparar as análises e os resultados da tendência e variabilidade na região de abrangência dessas localidades.

\section{2 - Metodologia}

A variabilidade pode ser entendida como a forma de variação dos valores de um elemento climático no interior de um determinado período de tempo. 
Para efeito de análise da variabilidade climática da temperatura e precipitação, dentro da série temporal escolhida, foram aplicados os cálculos da média aritmética, do desvio padrão e do coeficiente de variação, técnicas também utilizadas nos trabalhos de Ayoade (1986), Christofoletti (1992), Santos (1996), Roncato (2002), Mariano (2005) e Bieras (2006), conforme a sugestão da OMM - Organização Meteorológica Mundial.

\subsection{1 - Média Aritmética}

A média aritmética, considerada uma medida de tendência central, é muito utilizada para cálculos estatísticos de séries temporais.

Obtém-se a média aritmética de uma série constituída de $n$ elementos pela divisão da soma dos elementos pelo número deles. É um quociente geralmente representado pelo símbolo $\bar{x}$. Para uma série de $n$ valores de uma variável x, a média será obtida pela expressão:

$$
\bar{x}=\frac{x_{1}+x_{2}+\ldots+x_{n}}{n}=\frac{1}{n} \sum_{i=1}^{n} x_{i}
$$

\subsection{2 -Desvio Padrão}

Em Probabilidade e Estatística, o desvio padrão é a medida mais comum da dispersão estatística de um conjunto de dados. É uma medida de dispersão dos valores de uma distribuição normal em relação à sua média. $\mathrm{O}$ desvio padrão se define como a raiz quadrada da variância, fornecendo uma medida de dispersão que seja um número não-negativo e que utiliza a mesma unidade de medida dos dados fornecidos.

O termo desvio padrão foi introduzido na Estatística por Karl Pearson em 1894, no livro intitulado: Sobre a dissecção de curvas de freqüência assimétricas.

Se uma variável aleatória $x$ toma valores $x_{1}, \ldots, x_{\mathrm{n}}$, então o desvio padrão para essa amostra de n números pode ser calcula da seguinte forma. Primeiro calcula-se a média $\bar{x}$ e depois, o desvio padrão dado por: 


$$
S=\sqrt{\frac{1}{n-1} \sum_{i=1}^{n}\left(x_{i}-\bar{x}\right)^{2}}
$$

Esse desvio padrão muito usado em estatística indica o grau de variação de um conjunto de elementos. Se medirmos, por exemplo, a temperatura máxima durantes três dias em uma cidade e obtivermos os seguintes valores, $28^{\circ}, 29^{\circ}$ e $30^{\circ}$, é possível dizer que a média desses três dias é de $29^{\circ}$.

Em outra cidade, as temperaturas máximas, nesses mesmos dias, podem ter sido $22^{\circ} \mathrm{C}$, $29^{\circ} \mathrm{C}$ e $35^{\circ} \mathrm{C}$. Nesse caso, também a média dos três dias foi de $29^{\circ} \mathrm{C}$. As médias têm o mesmo valor, mas os moradores da primeira cidade viveram três dias de calor, enquanto os da segunda tiveram dois dias de calor e um de frio. Para diferenciar uma média da outra, criou-se a noção de desvio padrão, para dizer quanto os valores dos quais se extraiu a média estão próximos ou distantes da própria média. No exemplo acima, o desvio padrão da segunda cidade é muito maior que o da primeira.

\subsection{3 - Coeficiente de Variação}

O coeficiente de variação é uma medida de dispersão utilizada para a comparação de distribuições diferentes; é igual ao desvio padrão, dividido pela média, ou seja:

$$
c_{v}=\frac{S}{\bar{x}}
$$

$\mathrm{Na}$ maioria dos casos, o coeficiente de variação é multiplicado por 100; portanto, passa a ser expresso em porcentagem.

As fórmulas para o cálculo da média aritmética, desvio padrão e coeficiente de variação e a metodologia utilizadas no texto podem ser encontradas em Gerardi e Silva (1981) e Morettin e Bussab (2004). 


\section{3 - Análise da tendência}

\subsection{1 - Regressão Linear}

De posse dos dados, usou-se o programa Excel para a produção de planilhas, geração das tabelas e gráficos representativos das condições anuais; e, em seguida, aplicação dos cálculos para a verificação da tendência e variabilidade da precipitação e da temperatura.

Para a avaliação da precipitação foram considerados os totais mensais e anuais e, em relação à temperatura, foram consideradas as máximas e mínimas absolutas anuais e a média das máximas e das mínimas.

Para a análise da tendência, que visa a identificar se ocorre manutenção, aumento ou diminuição dos valores dos atributos climáticos dentro de uma série temporal, aplicou-se a técnica da regressão linear, baseada no método dos mínimos quadrados, que consiste no ajuste de uma reta a um conjunto de pontos. Esses procedimentos foram utilizados por Christofoletti (1992), Sentelhas et al (1994), Back (2001), Roncato (2002), Galina (2002), Bieras (2006), entre outros. O método dos mínimos quadrados busca minimizar a soma dos quadrados das diferenças entre os valores observados e os valores correspondentes na reta de tendência determinada pela equação:

$$
Y=Y_{m e d}+m X
$$

onde: $X$ e $Y$ são as variáveis e $m=\Sigma(X Y) / \Sigma X^{2}$.

As mesmas tabelas e gráficos permitiram, também, o cálculo dos coeficientes de determinação $\left(\mathrm{R}^{2}\right)$, que mostram, por meio da estatística descritiva, as tendências resultantes, o erro padrão das estimativas e os limites de confiança. É preciso acentuar que o valor de $\mathrm{R}$ mede o grau de relação correspondente ao tipo de equação utilizada e, se o valor de $\mathrm{R}$ for próximo de zero, significa que quase não há correlação linear entre as variáveis. As fórmulas e a metodologia utilizadas no texto podem ser encontradas em Morettin e Bussab (2004) e em Spiegel (1993).

No caso de $\mathrm{R}^{2}$, seus valores variam entre -1 e 1 , sendo que, quanto mais próximo de 1 , mais significativo o valor da correlação e tendência. Galvani (2005) mostra como trabalhar os princípios básicos da Estatística Descritiva para uma melhor análise dos dados obtidos, mencionando, inclusive, a importância da equação da reta $\mathrm{Y}=\mathrm{Ymed}+\mathrm{mX}$ e do coeficiente 
de determinação $\mathrm{R}^{2}$. Gerardi e Silva (1981) afirmam que é desejável calcular o erro padrão das estimativas para indicar até que ponto os valores observados diferem dos valores estimados através da reta de regressão e, então, determinar os limites de confiança a serem colocados no gráfico.

Uma tendência climática é entendida como uma alteração do clima, aumento ou diminuição lenta dos valores médios da série de dados analisadas no período de registro.

\subsection{2 - Testes Estatísticos de Mann-Kendall e Curvatura de Sen}

$\mathrm{Na}$ análise das tendências de precipitações e temperaturas foram considerados dados de uma série com totais anuais, submetidos a testes estatísticos não-paramétricos, conhecidos como testes de Mann-Kendall e Curvatura de Sen. O teste estatístico não-paramétrico de Mann-Kendall considera que, na hipótese de estabilidade de uma série temporal, a sucessão de valores ocorre de forma independente, e a distribuição de probabilidade deve permanecer sempre a mesma (série aleatória simples). De acordo com Önöz e Bayazit (2003), os benefícios desse teste são: a irrelevância de os dados não pertencerem a uma distribuição particular e o resultado dele é menos afetado, outliers, pois o cálculo baseia-se no sinal das diferenças e não diretamente nos valores da variável. A análise da tendência climática possibilita verificar se houve manutenção, aumento ou diminuição nos valores das variáveis climatológicas consideradas em uma determinada série temporal.

Para corroborar a metodologia empregada neste trabalho serão mencionados a seguir alguns autores e suas obras que utilizaram o método de regressão linear (mínimos quadrados), o teste não-paramétrico de Mann-Kendall e a Curvatura de Sen, com a finalidade de verificar a tendência de elementos climáticos em séries temporais. Nesses estudos, os testes utilizados foram os de Mann-Kendall, Curvatura de Sen e o de Regressão Linear.

Back (2001) obteve resultados que indicaram uma tendência significativa no aumento da temperatura média anual e na temperatura média do mês de janeiro, sendo que a mudança ocorreu no ano de 1965.

Tavares (2001), em sua tese de Livre Docência "Variabilidade e Mudanças Climáticas", utilizando dados meteorológicos de Piracicaba (SP), e a partir de técnicas 
estatísticas, verificou a ocorrência da variabilidade na série temporal analisada e mostrou que o fenômeno ENOS, é um fator importante na variabilidade do clima.

Galina (2002), Dissertação de Mestrado “Mudanças climáticas de curto prazo: Tendências dos regimes térmicos e hídricos e do balanço hídrico nos municípios de Ribeirão Preto, Campinas e Presidente Prudente (SP) no período de 1969-2001”, constatou que houve a tendência de aumento na temperatura média anual de $0,4{ }^{0} \mathrm{C}$ em Campinas, de $0,5{ }^{0} \mathrm{C}$ em Ribeirão Preto e um resultado mais crítico de $1,1{ }^{\circ} \mathrm{C}$ em Presidente Prudente.

Santos e Portela (2004), analisando séries temporais de 94 anos, em Portugal, aplicaram o teste estatístico não paramétrico de Mann-Kendall, para detectar tendências estatísticamente significativas, e a curvatura de Sen, para avaliar a magnitude dessas tendências, encontraram uma tendência mais frequente para a diminuição da pluviosidade, em nível mensal e anual e uma diminuição muito acentuada e generalizada para o mês de março.

Bieras e Santos (2006), no artigo, "Variabilidade e Tendência da Precipitação Pluviométrica Anual e Mensal do Município de Bebedouro (SP), no Período de 1983 A 2003”, mostraram uma nítida redução nos valores da variável precipitação durante a segunda metade da série temporal (1993 a 2003) em relação à primeira (1983 a 1992), sendo esta redução verificada tanto para os totais anuais quanto em nível mensal.

Folhes e Fisch (2006), no trabalho intitulado "Caracterização climática e estudo de tendências nas séries temporais de temperatura do ar e precipitação em Taubaté (SP)", apresentaram as principais características da distribuição temporal da precipitação e da temperatura, além de estabelecer uma caracterização do período da estação chuvosa. Quanto à temperatura, verificaram que não ocorreu tendência significativa.

Kuinchtner (2006), na sua dissertação de Mestrado: "Variabilidade da Temperatura Atmosférica Superficial no Planalto Meridional-Rio grandense", identificou a tendência de aumento da temperatura mínima média anual $\left(0,02{ }^{0} \mathrm{C} / \mathrm{ano}\right)$. Verificou também que a amplitude média anual da temperatura apresentou decréscimo na tendência (-0,02 $\left.{ }^{0} \mathrm{C} / \mathrm{ano}\right)$.

Dantas et al (2007), no artigo: “Classificação e Tendências Climáticas em Lavras, MG”, concluíram que houve uma mudança na série mais recente onde as temperaturas médias mensais aumentaram e os totais mensais de precipitação na série mais recente apresentaram diminuição.

Rodrigues e Santos (2007), no trabalho: "Estudo da Tendência Climática na Série Temporal de Precipitação Pluviométrica em Araguari (MG)", identificaram a ocorrência de uma tendência não significativa no primeiro trimestre da série temporal de 1975 a 2005 . Para o segundo, terceiro e quarto trimestres houve uma tendência negativa 
Galina et al (2007), no artigo "Mudanças Climáticas de Curto Prazo: Análise da Variabilidade Térmica e Hídrica e do Balanço Hídrico na localidade de Ribeirão Preto (SP)”, identificaram mudanças climáticas de curto prazo na escala local no período estudado.

Winke et al (2008), no estudo da: "Caracterização Climática e Estudo de Tendências nas Séries Temporais de Temperatura e Precipitação em Pelotas/RS", concluíram que ocorreu tendência crescente das temperaturas mínima médias anuais e que para os outros parâmetros não houve tendência significativa.

Campos e Ruivo (2009), no trabalho: “Análise da Tendência climática para a Cidade de Corumbá (MGS)", apresentado em simpósio concluíram que tendências positivas significantes para a temperatura média $\left(0.02^{\circ} \mathrm{C} /\right.$ mês $)$ e mínima $\left(0.04^{\circ} \mathrm{C} / \mathrm{mês}\right)$, umidade relativa $(0.15 \%$ /mês $)$ e precipitação $(0.88 \mathrm{~mm} / \mathrm{mês})$. Para a temperatura máxima, a tendência não foi significante.

Blain et al (2009), no artigo: “Análises Estatísticas das Tendências de Elevação nas Séries Anuais de Temperatura Mínima do Ar no Estado de São Paulo", concluíram que em apenas três localidades ocorreu uma tendência significativa da temperatura mínima: Campinas, Cordeirópolis/Limeira e Ribeirão Preto. Nas demais localidades não houve tendência significativa de elevação da temperatura mínima.

Cordeiro (2010), em sua Dissertação de Mestrado; “Tendências Climáticas das Variáveis Meteorológicas Originais, Estimadas e das Derivadas do Balanço Hídrico Seriado do Estado do Rio Grande do Sul", concluiu que a precipitação apresentou forte tendência de aumento. Das temperaturas, a mínima foi destacadamente, a que apresentou maior aumento.

No trabalho, "Oscilações Climáticas em Minas Gerais", Minuzzi et al (2010), verificaram que os resultados mais relevantes indicaram que a temperatura máxima e mínima tiveram um crescimento no período de $1960-2004$, entre $1,3{ }^{\circ} \mathrm{C}$ e $3,0{ }^{\circ} \mathrm{C}$ e que a maior parte do crescimento significativo da temperatura máxima ocorreu entre setembro e dezembro.

Minuzzi (2010), no artigo: “Tendência na Variabilidade Climática de Santa Catarina, Brasil", identificou que a temperatura máxima apresentou tendência de diminuição e a mínima de aumento.

Minuzzi e Caramori (2010), no artigo: "Tendência Climática Sazonal e anual da quantidade de chuva no estado do Paraná", mostraram que houve um aumento na quantidade de chuvas desde meados do século XX, principalmente durante a primavera e na metade leste do estado (entre 17 a $37 \mathrm{~mm} /$ década)

Fechine e Galvíncio (2010), no artigo: “Aplicação do Teste de Mann- Kendall na Análise de Tendências Climáticas em Anos de El Niño na Bacia Hidrográfica do Rio Pontal- 
Estado de Pernambuco" mostraram que $87 \%$ dos postos meteorológicos possuem tendência não significativa de queda nos índices pluviais, 6,5\% apontam para tendências negativas de queda e 55\% com tendência significativa de aumento.

\subsection{3 -. Estimativa das Tendências}

A estimativa da magnitude das tendências pode ser realizada pelo cálculo do coeficiente angular da equação da reta obtida com a utilização do método de regressão linear, mas este coeficiente pode desviar-se muito do valor verdadeiro da inclinação da reta, se na série de dados existirem valores extremos (GILBERT, 1983).

Para obter a magnitude das tendências da série, utilizou-se o método denominado Curvatura de Sen, Sen (1968) estendido por Hirsch et al. (1984). Para o cálculo da Curvatura de Sen $b$, primeiro é calculada todas as curvaturas de todos os pares de valores usando uma série temporal. Como a Curvatura de Sen é insensível a valores outliers e dados ausentes, é mais rigoroso que a usual curvatura de regressão e provê uma medida realística das tendências numa série temporal.

No Método de Sen a estimativa da inclinação que indica uma possível tendência é obtida pelo cálculo dos pares de valores da série $x_{1}, x_{2}, x_{3}, \ldots, x_{n}$ com a aplicação da fórmula abaixo

$$
S_{e}=\frac{x_{j}-x_{i}}{j-i}
$$

onde, $S_{e}$ é o valor estimado da inclinação de Sen, ou seja, o acréscimo ou decréscimo em função do tempo é dado pela seguinte expressão $f(t)=S_{e} t+B$, onde B uma constante. O teste de Sen possibilita identificar se houve, ou não, mudança de tendência e a magnitude na série, sendo uma técnica muito utilizada para a verificação da magnitude, (DEO et al, 2007 , YUE e HASHINO, 2003).

\subsection{4 - Determinação da Significância Estatística das Tendências.}


Para verificar a ocorrência de tendências estatisticamente significativas, das variáveis estudadas (temperatura e precipitação), nas séries de dados temporais, foram aplicados testes estatísticos de análises não-paramétricas de Mann-Kendall. Proposto inicialmente por Sneyers (1975), o teste não paramétrico de Mann-Kendall é recomendado pela Organização Meteorológica Mundial (OMM), para a verificação de tendências em séries temporais de elementos climáticos (YU e al., 2002). Esse mesmo teste foi aplicado também por Marengo e Alves (2005) em estudos hidrológicos na Bacia do Rio Paraíba do Sul. O teste de MannKendall considera que os dados precisam ser variáveis aleatórias independentes, e identicamente distribuídas. As características desse teste são importantes quando aplicados às séries climatológicas, como precipitação, porque não dependem do tipo de série temporal. Goossens \& Berger (1986) afirmam que o teste de Mann-Kendall é apropriado para analisar mudanças climáticas em séries temporais porque permite a detecção e localização aproximada do ponto inicial de determinada tendência.

\section{4 - Fórmulas da Estatística de Mann-Kendall.}

Para um conjunto de dados $x_{1}, x_{2}, x_{3}, \ldots, x_{n}$, com $n>4$, o teste estatístico de MannKendall $S$, usa as seguintes fórmulas para a estatística de Mann-Kendall, como sendo:

$$
S=\sum_{k=1}^{n-1} \sum_{j=k+1}^{n} \operatorname{sign}\left(x_{j}-x_{k}\right)
$$

onde a função signé:

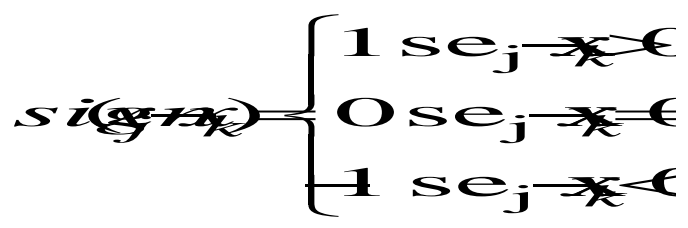

A variância de $S$, denotada por [ $\operatorname{Var}(S)]$, é definida por

$$
\operatorname{Var}(S)=\frac{n(n-1)(2 n+5)}{18}
$$

e, com repetições de dados, a variância fica sendo:

$$
\operatorname{Var}(S)=\frac{1}{18}\left[n(n-1)(2 n+5)-\sum_{p=1}^{g} t_{p}\left(t_{p}-1\right)\left(2 t_{p}+5\right)\right]
$$


onde, $g$ é número de grupos com dados repetidos e $t_{p}$ é o número de dados no p-ésimo grupo. Logo $S$ e $\operatorname{Var}(S)$ são utilizados para o cálculo da estatística $Z$, com distribuição normal padrão:

$$
Z=\left\{\begin{array}{ccc}
\frac{S-1}{[\operatorname{VAR}(S)]^{\frac{1}{2}}} & \text { se } S>0 \\
0 & \text { se } S>0 \\
\frac{S+1}{[\operatorname{VAR}(S)]^{\frac{1}{2}}} & \text { se } S<0
\end{array}\right.
$$

Para a análise da tendência utiliza-se valor de $Z$. Um valor positivo de $Z>0$ significa uma tendência crescente e um valor negativo $Z<0$, uma tendência decrescente.

O nível de significância $\alpha$ adotado é de $\alpha=0,05=5 \%$ para o Teste de MannKendall. Se a probabilidade $p$ do Teste de Mann-Kendall for menor que o nível $\alpha, p<\alpha$, uma tendência estatisticamente significante existe, enquanto, um valor de $p>\alpha$, confirma uma tendência insignificante. Para amostras onde não há tendência, o valor de $Z$ é próximo de zero e o valor de p é próximo de $\alpha$.

Maiores detalhes sobre a metodologia são encontrados em Mann (1945), Kendall (1975), Gilbert (1983), Hirsch e Slack (1984), Morettin e Bussab (2004) e Spiegel (1993).

Tanto a estatística de Mann-Kendall quanto como a Curvatura de Sen foram calculadas utilizando o softwares Statistica, BioEstat 3,0 e MatLab®.

Nos estudos para a verificação de tendências da temperatura e precipitação, os testes utilizados foram os de Mann-Kendall, Curvatura de Sen e o de Regressão Linear 


\section{5 - DISCUSSÃO DOS RESULTADOS}

Neste capítulo serão apresentados os resultados e análises da variabilidade e tendência anual e mensal para as temperaturas médias, máximas, mínimas, médias máximas, médias mínimas e pluviosidade para as localidades em estudo. Primeiramente para Pirassununga, com uma série temporal mais longa, de 1976 a 2009 e, depois, para Pirassununga, Rio Claro, São Carlos e São Simão, localidades situadas no estado de São Paulo, para uma série temporal mais curta, de 1994 a 2009, período escolhido por não apresentar falhas nos registros de dados coletados, de modo a tornar a análise comparativa e coerente para comprovar se na escala local estão ocorrendo alterações significativas na tendência e variabilidade da precipitação e temperatura (mensais e anuais), das quatro localidades, objetivo principal desta pesquisa.

\section{1 - Análise dos dados de temperatura e pluviosidade da série temporal de 1976 a 2009, para Pirassununga/SP.}

\subsection{1 - Análise da variabilidade da temperatura}

\subsubsection{1 - Temperatura média}

A temperatura média anual durante a série temporal considerada $(1976$ - 2009) é de $22,6^{\circ} \mathrm{C}$, com média mais elevada de $23,8^{\circ} \mathrm{C}$, registrada em 1984 e média mais baixa, de $20,4^{\circ}$ C, em 2004, de acordo com a tabela do Anexo A.

Quanto ao comportamento mensal dessa variável (Tabela 1), o primeiro e o último trimestre do ano representam o período de temperaturas mais elevadas, sendo fevereiro o mês mais quente do ano, com média mensal de $25,2^{\circ} \mathrm{C}$, desvio padrão de $1,2^{\circ} \mathrm{C}$, coeficiente de variação de $4,74 \%$ e temperatura média máxima igual a $27,9^{\circ} \mathrm{C}$. Já os meses de maio, junho, julho e agosto representam o período do ano com temperaturas menos elevadas, sendo junho o mais frio do ano, com temperatura média de $18,5^{\circ} \mathrm{C}$, desvio padrão de $1,1^{\circ} \mathrm{C}$, coeficiente de variação de $5,9 \%$ e temperatura média máxima de $20,7^{\circ} \mathrm{C}$. O mês com maior coeficiente de 
variação é julho $(\mathrm{CV}=7 \%)$, caracterizando maior variabilidade da temperatura média do ar para a série. $\mathrm{O}$ mês com menor coeficiente de variação é dezembro $(\mathrm{CV}=3,2 \%)$, com pouca variabilidade, ou seja, a temperatura manteve-se próxima de um valor constante para todos os meses de dezembro da série.

Tabela 1 - Valores da temperatura média, desvio padrão (DP) e coeficiente de variação (CV) da temperatura média anual e mensal no município de Pirassununga/SP para os anos de 1976 a 2009.

\begin{tabular}{cccccc}
\hline Anual/mensal & $\begin{array}{c}\text { Média } \\
\left({ }^{\mathbf{}} \mathbf{C}\right)\end{array}$ & $\begin{array}{c}\mathbf{D P} \\
\left({ }^{\mathbf{0}} \mathbf{C}\right)\end{array}$ & $\begin{array}{c}\mathbf{C V} \\
(\mathbf{\%})\end{array}$ & $\begin{array}{c}\text { MaxMed } \\
\left({ }^{\mathbf{}} \mathbf{C}\right)\end{array}$ & $\begin{array}{c}\text { MinMed } \\
\left({ }^{\mathbf{}} \mathbf{C}\right)\end{array}$ \\
\hline jan. & 24,9 & 0,9 & 3,6 & 27 & 23,2 \\
fev. & 25,2 & 1,2 & 4,7 & 27,9 & 23,1 \\
mar. & 24,7 & 1,1 & 4,4 & 26,5 & 22,4 \\
abr. & 22,9 & 1,5 & 6,5 & 25,7 & 16,9 \\
Maio & 19,2 & 1,2 & 6 & 22,2 & 17,1 \\
jun. & 18,5 & 1,1 & 5,9 & 20,7 & 16,5 \\
jul. & 18,8 & 1,4 & 7,4 & 21,7 & 16,3 \\
ago. & 20,9 & 1,2 & 5,7 & 23,2 & 18,9 \\
set. & 22,4 & 1,3 & 5,8 & 25,1 & 20,2 \\
out. & 24,4 & 1,4 & 5,7 & 27,5 & 21,1 \\
nov. & 24,7 & 0,9 & 3,6 & 26,5 & 23,1 \\
dez. & 24,7 & 0,8 & 3,2 & 26,4 & 22,7 \\
Anual & $\mathbf{2 2 , 6}$ & $\mathbf{0 , 6}$ & $\mathbf{2 , 6}$ & $\mathbf{2 3 , 8}$ & $\mathbf{2 1 , 1}$ \\
\hline
\end{tabular}

A análise do comportamento dessa variável climática ao longo da série (Gráfico 1), mostra que, dos trinta e quatro anos, somente dez apresentaram temperatura média anual abaixo da média da série, sendo que os últimos sete anos da série apontam para uma diminuição dos valores médios, com desvio padrão de $0,6^{\circ} \mathrm{C}$ e coeficiente de variação de 2,6\%, conforme a Tabela 1. É possível concluir também, da coluna das temperaturas médias, uma amplitude térmica de $6,7^{\circ} \mathrm{C},\left(25,2^{\circ} \mathrm{C}-18,5^{\circ} \mathrm{C}\right)$, indicando uma grande variabilidade para essa variável em relação ao mês mais quente e o mais frio do período. 


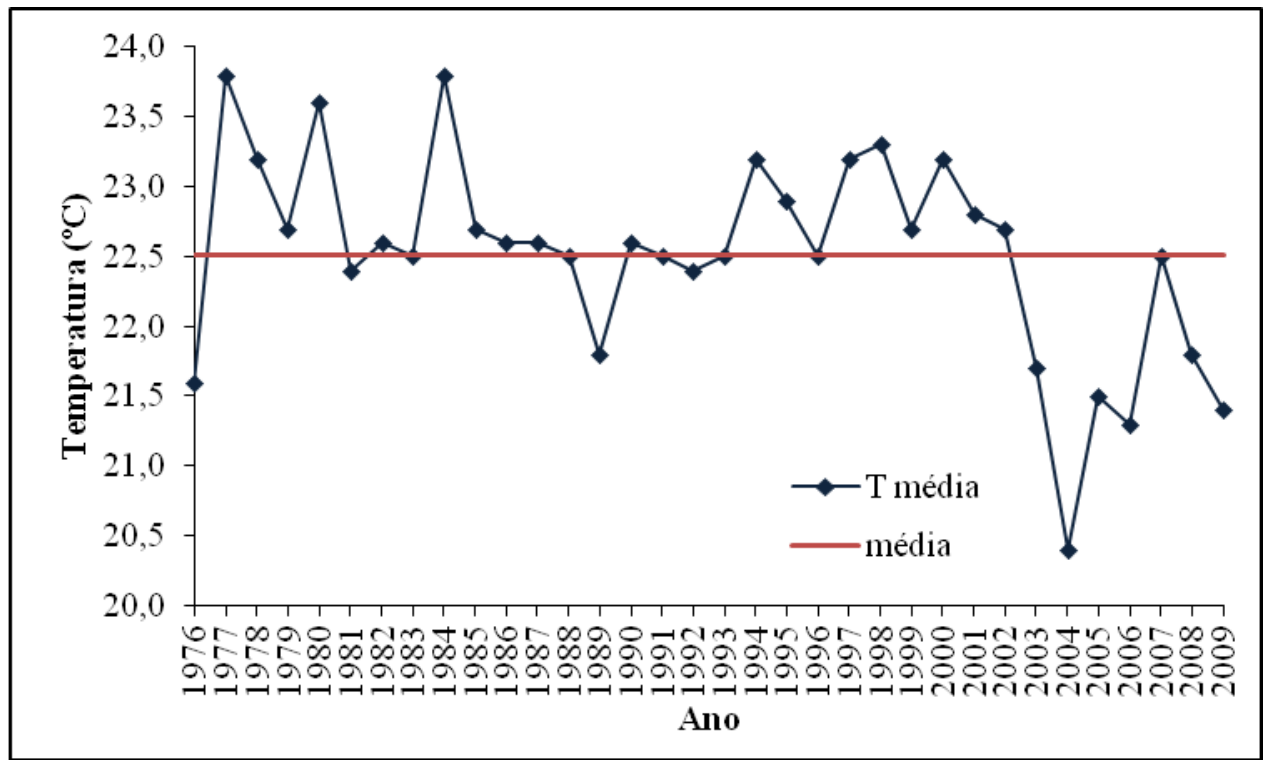

Gráfico 1 - Temperatura média anual no município de Pirassununga/SP para os anos de 1976 a 2009.

\subsubsection{2 - Temperatura máxima}

A média das temperaturas máximas para o período considerado é de $36,2^{\circ} \mathrm{C}$, com maior máxima de $39^{\circ} \mathrm{C}$, nos anos de 1997 e 2008 ; e a menor máxima é de $33^{\circ} \mathrm{C}$, em 1992 , conforme mostrado no Anexo B.

Em relação ao comportamento mensal da temperatura máxima, Tabela 2, os valores dessa variável mostraram que o mês de outubro é o mais quente da série, com temperatura média máxima de $35,4^{\circ} \mathrm{C}$, máxima de $39^{\circ} \mathrm{C}$ e mínima máxima de $32^{\circ} \mathrm{C}$, com um desvio padrão de $1,9^{\circ} \mathrm{C}$ e coeficiente de variação de 5,3\%. Na mesma linha de análise, junho é o mês mais frio, com temperatura média máxima de $29,3^{\circ} \mathrm{C}$, mínima máxima de $26,3^{\circ} \mathrm{C}$, desvio padrão de $1,6^{\circ} \mathrm{C}$ e coeficiente de variação de $5,4 \%$. Há também uma amplitude térmica de $6,1^{\circ} \mathrm{C}$ $\left(35,4^{\circ} \mathrm{C}-29,3^{\circ} \mathrm{C}\right)$ em relação às temperaturas médias máximas, apontando para uma grande variabilidade no período considerado. 
Tabela 2 - Valores da temperatura máxima, desvio padrão (DP) e coeficiente de variação (CV) da temperatura máxima anual e mensal no município de Pirassununga/SP para os anos de 1976 a 2009.

\begin{tabular}{cccccc}
\hline Anual/mensal & $\begin{array}{c}\text { Méd Max } \\
\left({ }^{\mathbf{}} \mathbf{C}\right)\end{array}$ & $\begin{array}{c}\text { DP } \\
\left({ }^{\mathbf{}} \mathbf{C}\right)\end{array}$ & $\begin{array}{c}\mathbf{C V} \\
(\mathbf{\%})\end{array}$ & $\begin{array}{c}\text { MaxMax } \\
\left({ }^{\mathbf{}} \mathbf{C}\right)\end{array}$ & $\begin{array}{c}\text { MinMax } \\
\left({ }^{\mathbf{}} \mathbf{C}\right)\end{array}$ \\
\hline jan. & 33,4 & 2,2 & 6,5 & 36,4 & 24,4 \\
fev. & 33,6 & 1,2 & 3,5 & 35,6 & 31,0 \\
mar. & 33,4 & 1,4 & 4,2 & 36,8 & 29,7 \\
abr. & 32,1 & 1,2 & 3,7 & 34,1 & 29,4 \\
maio & 30,3 & 1,2 & 3,9 & 32,4 & 28,0 \\
jun. & 29,3 & 1,6 & 5,4 & 35,0 & 26,3 \\
jul. & 30,3 & 1,3 & 4,3 & 32,9 & 27,2 \\
ago. & 32,9 & 1,2 & 3,6 & 35,4 & 30,7 \\
set. & 34,1 & 2,5 & 7,3 & 38,4 & 25,7 \\
out. & 35,4 & 1,9 & 5,3 & 39,0 & 32,0 \\
nov. & 34,6 & 1,5 & 4,3 & 38,0 & 32,0 \\
dez. & 33,4 & 1,9 & 5,6 & 37,1 & 29,6 \\
Anual & $\mathbf{3 1 , 9}$ & $\mathbf{0 , 8}$ & $\mathbf{2 , 5}$ & $\mathbf{3 4 , 3}$ & $\mathbf{3 1 , 2}$ \\
\hline
\end{tabular}

O comportamento da temperatura máxima ao longo da série, conforme Gráfico 2, mostra que foram registrados vinte valores abaixo da média $\left(36,2^{\circ} \mathrm{C}\right)$ e somente quatorze valores acima da média, com desvio padrão de $0,8^{\circ} \mathrm{C}$ e coeficiente de variação de $2,5 \%$, valores muito próximos dos encontrados para a temperatura média.

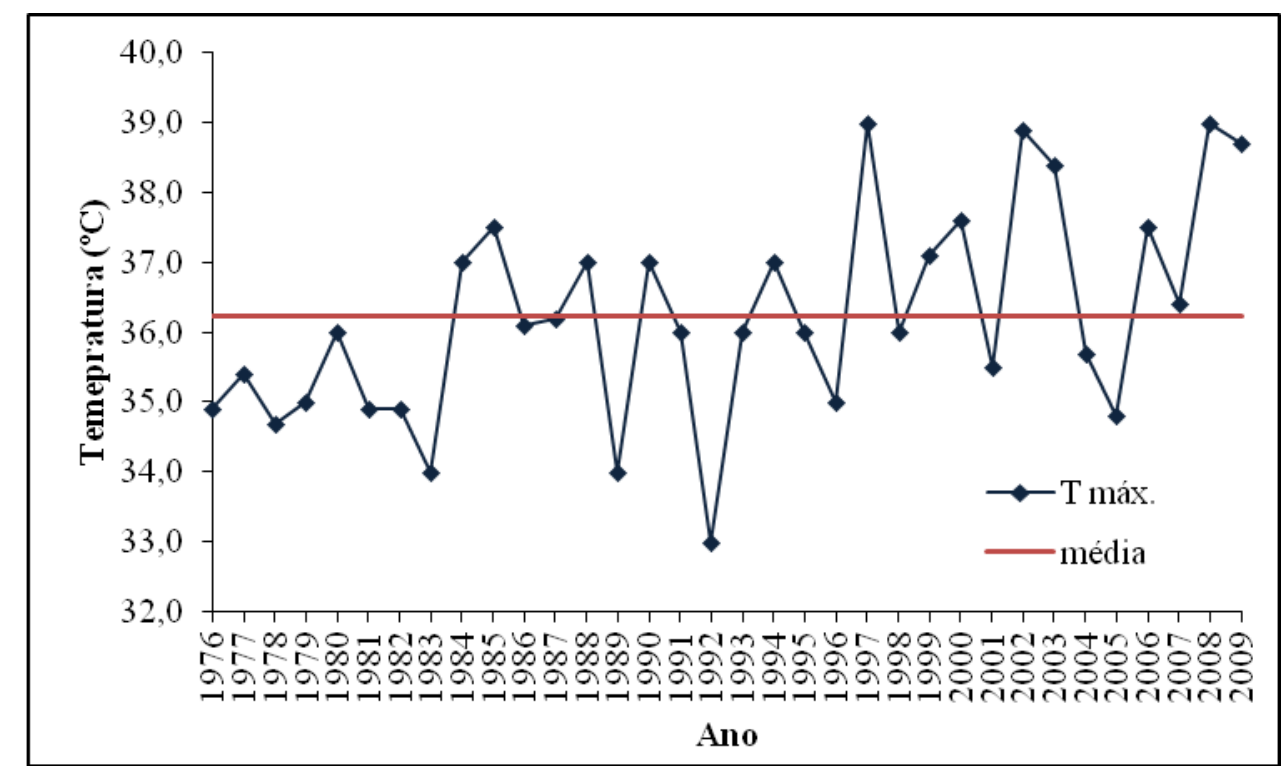

Gráfico 2 - Temperatura máxima anual no município de Pirassunung/SP para os anos de 1976 a 2009. 


\subsubsection{3 - Temperatura mínima}

A média das temperaturas mínimas para o período é de $2,5^{\circ} \mathrm{C}$. A maior mínima, igual a $7^{\circ} \mathrm{C}$, ocorreu em 1997 e a menor mínima, de $-2^{\circ} \mathrm{C}$, em 1994 , como pode ser verificado no Anexo C.

A análise do comportamento mensal da temperatura mínima (Tabela 3) mostra que os meses de janeiro e fevereiro são os mais quentes da série, com média mínima de $16,7^{\circ} \mathrm{C}$ e $16,4^{\circ} \mathrm{C}$, máxima mínima de $19^{\circ} \mathrm{C}$ e $19,2^{\circ} \mathrm{C}$, respectivamente. Mostra também que os meses mais frios são junho e julho, com média mínima de $4,3{ }^{\circ} \mathrm{C}$ e $4,1^{\circ} \mathrm{C}$, máxima mínima de $8,8^{\circ} \mathrm{C}$ e $9^{\circ} \mathrm{C}$ e mínima de $-2^{\circ} \mathrm{C}$ e $-1,4^{\circ} \mathrm{C}$, respectivamente. A amplitude térmica para esta variável é de $12,6^{\circ} \mathrm{C},\left(16,7^{\circ} \mathrm{C}-4,1^{\circ} \mathrm{C}\right)$, apontando também para uma variabilidade climática ainda mais acentuada no período, conforme evidenciada para as temperaturas médias e máximas.

Tabela 3 - Valores da temperatura mínima, desvio padrão (DP) e coeficiente de variação (CV) da temperatura mínima anual e mensal no município de Pirassununga/SP para os anos de 1976 a 2009.

\begin{tabular}{cccccc}
\hline Anual/mensal & $\begin{array}{c}\text { Méd Min } \\
\left({ }^{\mathbf{0}} \mathbf{C}\right)\end{array}$ & $\begin{array}{c}\mathbf{D P} \\
\left({ }^{\mathbf{}} \mathbf{C}\right)\end{array}$ & $\begin{array}{c}\mathbf{C V} \\
(\mathbf{\%})\end{array}$ & $\begin{array}{c}\text { Max in } \\
\left({ }^{\mathbf{}} \mathbf{C}\right)\end{array}$ & $\begin{array}{c}\text { MinMin } \\
\left({ }^{\mathbf{}} \mathbf{C}\right)\end{array}$ \\
\hline jan. & 16,70 & 1,70 & 10,2 & 19,00 & 10,00 \\
fev. & 16,40 & 2,20 & 13,4 & 19,20 & 7,30 \\
mar. & 15,40 & 1,70 & 11,0 & 17,80 & 10,40 \\
abr. & 10,90 & 2,60 & 23,8 & 14,90 & 2,30 \\
maio & 6,48 & 2,80 & 43,2 & 12,80 & 1,00 \\
jun. & 4,30 & 2,50 & 58,1 & 8,80 & $-2,00$ \\
jul. & 4,10 & 2,90 & 70,7 & 9,00 & $-1,40$ \\
ago. & 6,30 & 2,60 & 41,2 & 12,30 & 0,70 \\
set. & 8,80 & 2,10 & 17,2 & 12,00 & 3,20 \\
out. & 12,20 & 1,80 & 14,7 & 15,00 & 7,30 \\
nov. & 13,80 & 1,80 & 13,0 & 17,00 & 9,80 \\
dez. & 15,30 & 2,00 & 13,1 & 18,60 & 10,00 \\
Anual & $\mathbf{1 1 , 3 0}$ & $\mathbf{0 , 8 0}$ & $\mathbf{7 , 1}$ & $\mathbf{1 2 , 3 0}$ & $\mathbf{8 , 6 0}$ \\
\hline
\end{tabular}

A distribuição da temperatura mínima ao longo da série, conforme o Gráfico 3, registrou dezesseis valores abaixo da média $\left(2,5^{\circ} \mathrm{C}\right)$ e dezoito acima da média, com desvio padrão de $0,8^{\circ} \mathrm{C}$ e coeficiente de variação de $7,1 \%$, indicando uma pequena oscilação em torno da média, mesmo com valores extremos bem diferenciados, máximo de $7^{\circ} \mathrm{C}$ e mínimo de $-2^{\circ} \mathrm{C}$. 


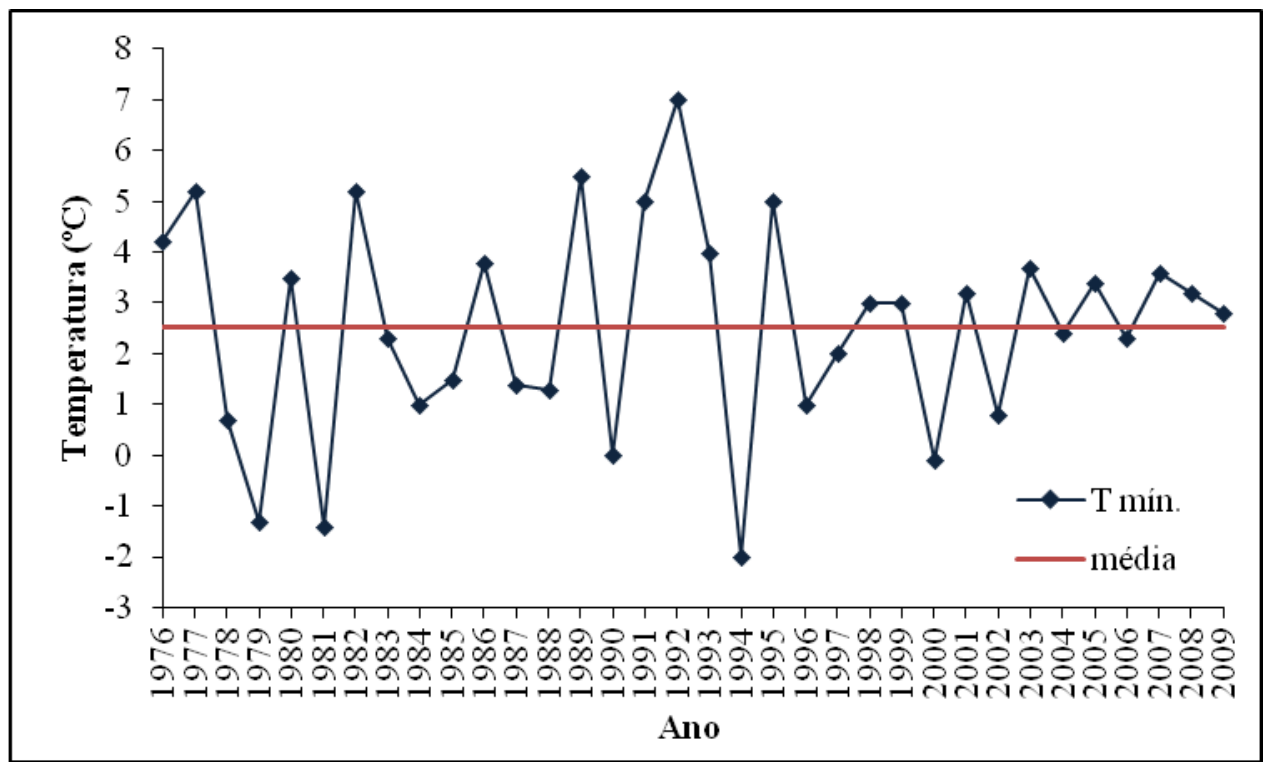

Gráfico 3 - Temperatura mínima anual no município de Pirassununga/SP para os anos de 1976 a 2009.

Ainda em relação ao comportamento anual da temperatura durante a série temporal analisada (1976-2009), as temperaturas máximas variam de $33^{\circ} \mathrm{C}$ em 1992 até $39^{\circ} \mathrm{C}$ em 1997 e 2008 (Gráfico 2); e as mínimas de $7^{\circ} \mathrm{C}$ em 1992 até $-2^{\circ} \mathrm{C}$ em 1994 (Gráfico 3). A maior amplitude térmica anual observada foi de $39^{\circ} \mathrm{C}$, (variando de $-2^{\circ} \mathrm{C}$ até $37^{\circ} \mathrm{C}$ ), registrada em 1994; e a menor, $26^{\circ} \mathrm{C}$ (variando de $7^{\circ} \mathrm{C}$ até $33^{\circ} \mathrm{C}$ ), registrada em 1992, podendo-se considerálos como anos excepcionais em relação à média da série. A análise das temperaturas máximas do período mostra uma variabilidade bastante acentuada. Nos últimos quatro anos da série verifica-se um aumento das temperaturas máximas e também das mínimas nos últimos seis anos em relação às médias da série.

\subsubsection{4 - Temperatura média máxima.}

A observação do comportamento da TMedMax permite verificar que não houve uma tendência estatística significativa para o período 1976-2009. Conforme o Gráfico 4, a temperatura média para o período é de $32,7^{\circ} \mathrm{C}$, sendo a máxima $34,3^{\circ} \mathrm{C}$ em1999 e a mínima de $31,1^{\circ} \mathrm{C}$ em 2004, mostrando a ocorrência de baixa variabilidade para essa variável. 


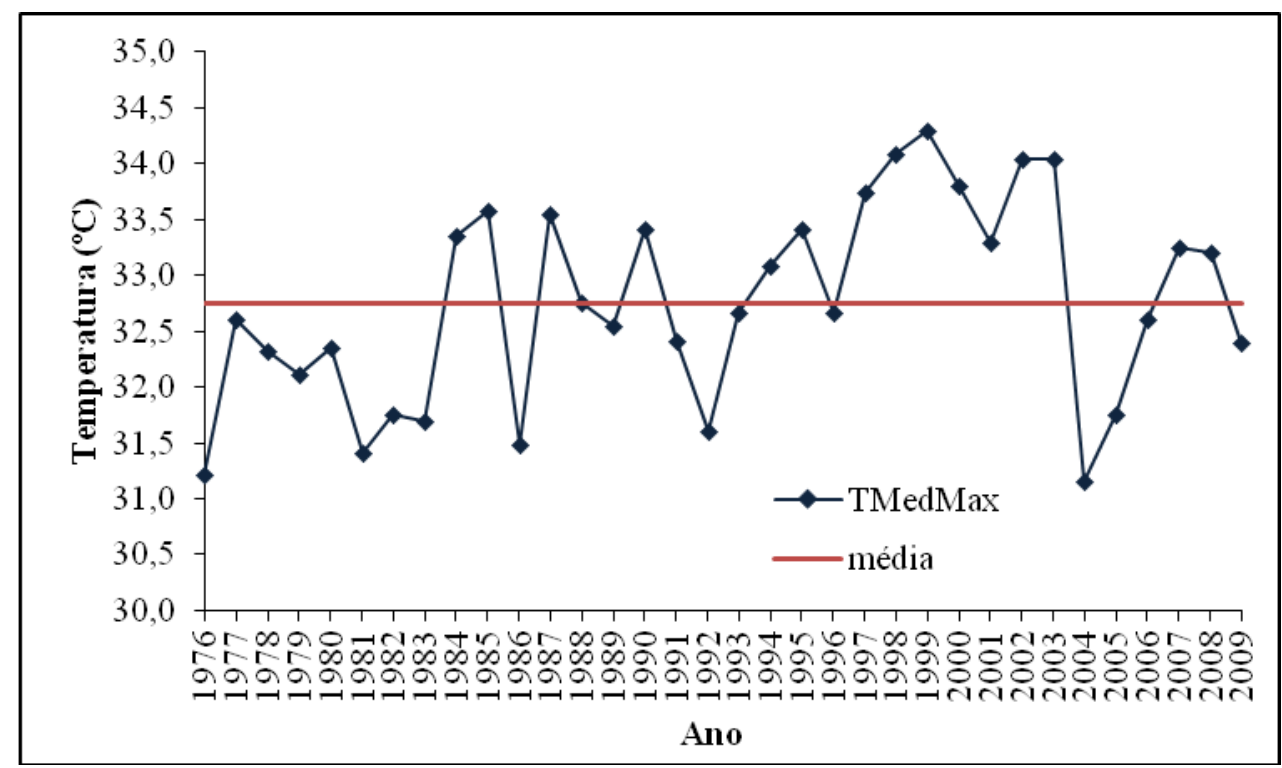

Gráfico 4 - Média das temperaturas máximas anual (TMedMax) no município de Pirassununga/SP para os anos de 1976 a 2009.

\subsubsection{5 - Temperatura média mínima}

O Gráfico 5 mostra que, durante o período, a TMedMin oscilou entre os valores de $12,3^{\circ} \mathrm{C}$ em 1977 e $8,2^{\circ} \mathrm{C}$ em 2004 , com uma média de $10,9^{\circ} \mathrm{C}$ para o período, observando-se baixa variabilidade para a série.

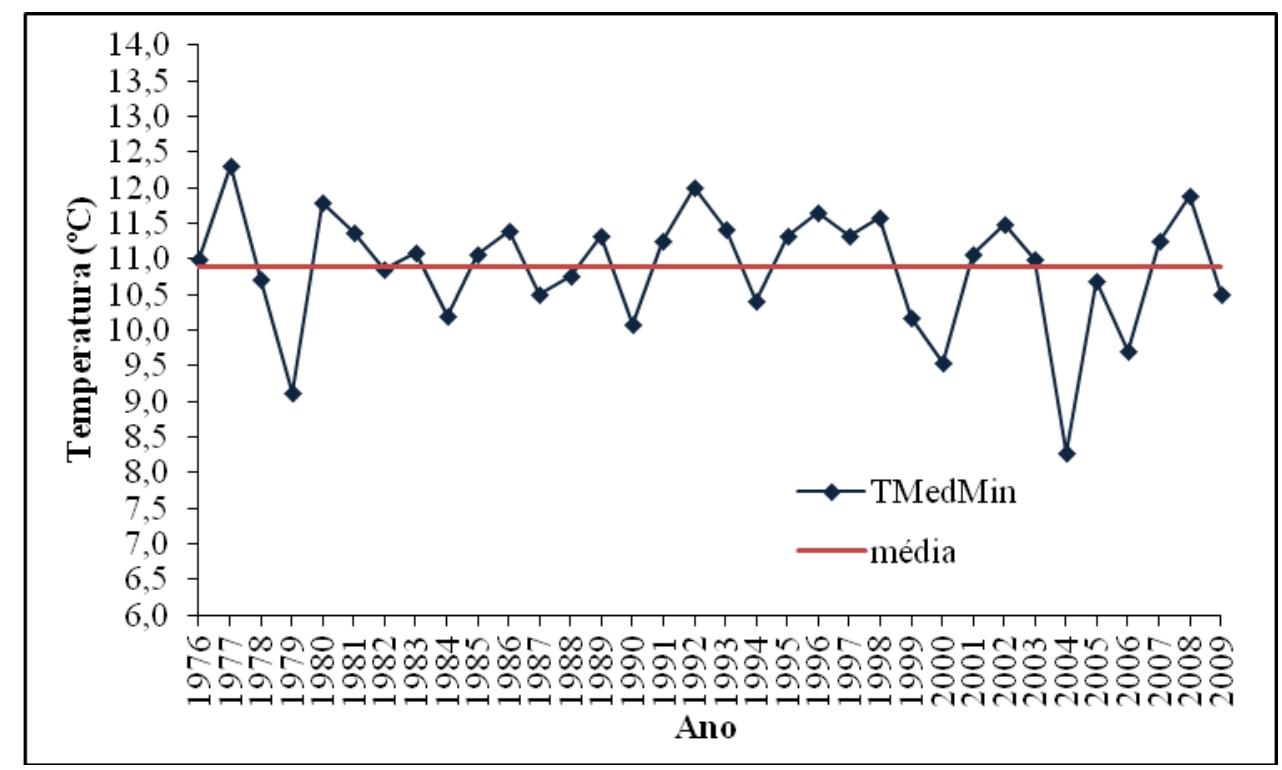

Gráfico 5 - Média das temperaturas mínimas anual (TMedMin) no município de Pirassununga/SP para os anos de 1976 a 2009. 


\subsection{2 - Análise da tendência para as temperaturas médias, máximas, mínimas, média máxima e média mínima: retas de regressão.}

São apresentados, a seguir e em sequência, os gráficos de regressão linear e as análises das tendências e estimativas para a temperatura relativas ao período estudado.

A temperatura média apresenta uma tendência de diminuição a uma taxa anual de $0,034^{\circ} \mathrm{C}$. Em 1977, com temperatura média de $23,8^{\circ} \mathrm{C}$, foi o ano mais quente, enquanto 2004 , com temperatura de $20,4^{\circ} \mathrm{C}$, mostrou-se como o mais frio, apresentando uma amplitude térmica de $3,4^{\circ} \mathrm{C}$ para o período. O coeficiente de determinação que explica a variação da temperatura média em relação ao do tempo, obtido da reta ajustada aos dados, é $\mathrm{R}^{2}=0,2149$ (Gráfico 6). Assim, o Gráfico 6 mostra a reta de tendência apontando para um decréscimo de $1,16^{\circ} \mathrm{C}$ na temperatura média anual durante o período de trinta e quatro anos de observação da série considerada.

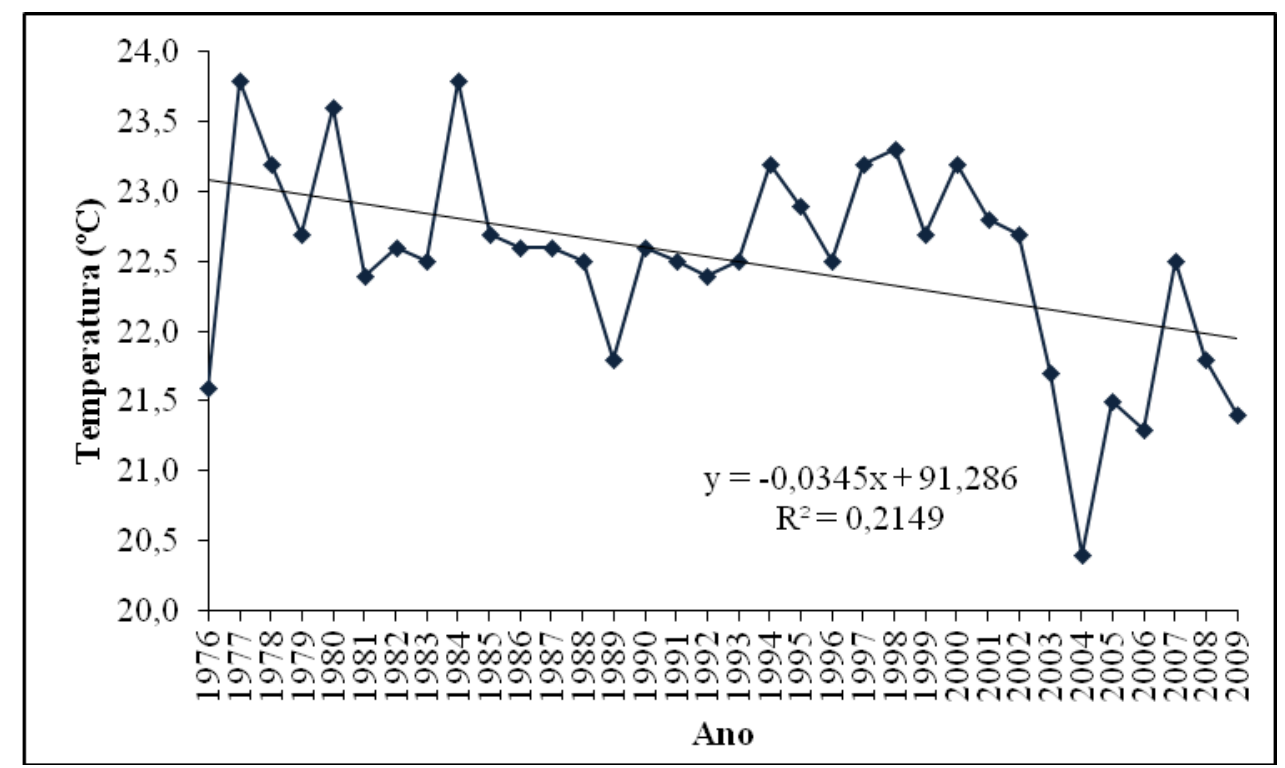

Gráfico 6 - Reta de regressão para a temperatura média anual no município de Pirassununga/SP para os anos de 1976 a 2009.

A análise do Gráfico 7 indica que a reta ajustada para o período apresentou uma clara tendência de ascensão, evidenciada pelo coeficiente angular, com $\mathrm{R}^{2}=0,272$ e uma propensão à elevação da temperatura máxima numa razão de $0,079^{\circ} \mathrm{C} / \mathrm{ano}$. A maior temperatura máxima ocorreu nos anos de 1997 e 2004 (39 $\left.{ }^{\circ} \mathrm{C}\right)$, e a menor, em 1992 (33 $\left.{ }^{\circ} \mathrm{C}\right)$, resultando em uma amplitude térmica de $6^{\circ} \mathrm{C}$ para o período, com um aumento do número de dias mais quentes. 
Assim, conforme o Gráfico 7, a reta de tendência aponta para um aumento de $2,68^{\circ} \mathrm{C}$ na temperatura máxima durante os trinta e quatro anos de observação da série considerada.

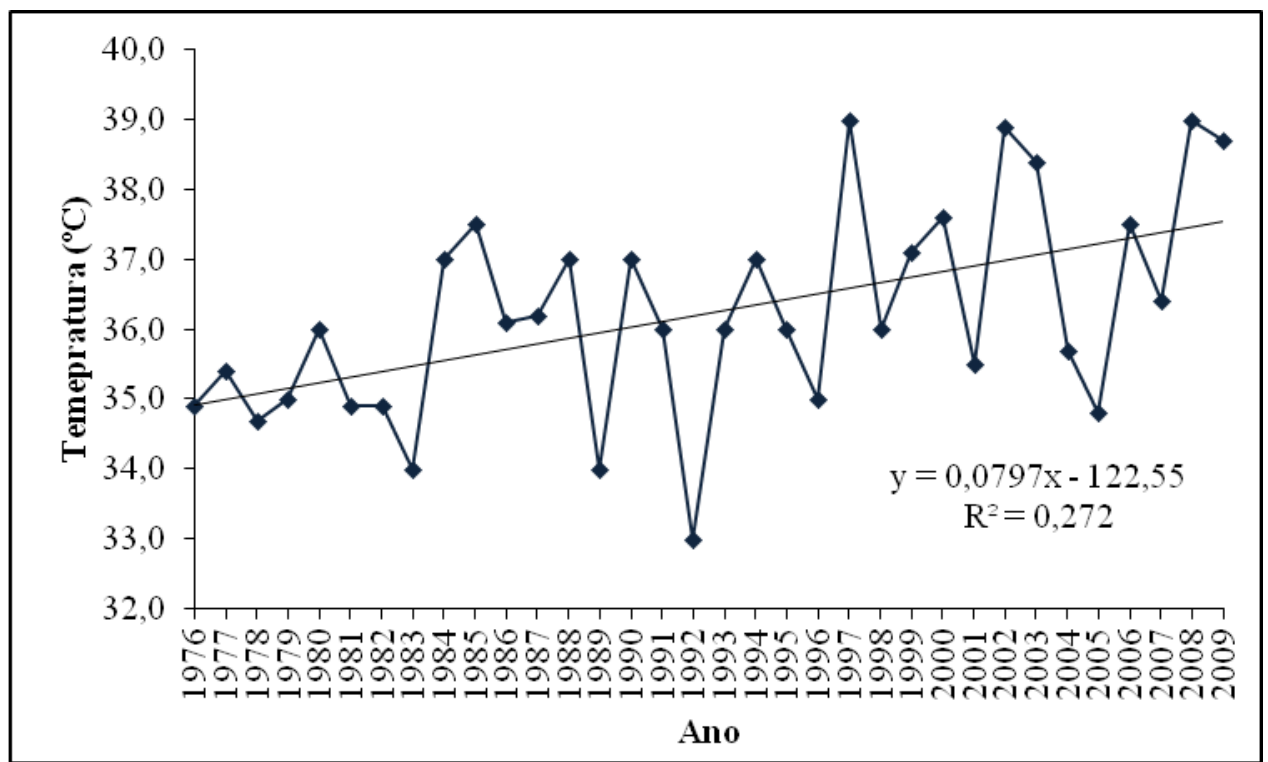

Gráfico 7 - Reta de regressão para a temperatura máxima anual no município de Pirassununga/SP para os anos de 1976 a 2009.

Em relação à temperatura mínima, o Gráfico 8 mostra que ocorre uma pequena tendência de aumento, na razão de $0,014^{\circ} \mathrm{C}$ ao ano, com $\mathrm{R}^{2}=0,0046$, muito baixo, mostrando que a reta não se ajusta muito bem aos dados da série. A maior temperatura mínima foi de $7^{\circ} \mathrm{C}$ em 1992 e a menor, $-2^{\circ} \mathrm{C}$, em 1994 , estabelecendo uma amplitude de $9^{\circ} \mathrm{C}$ para a série em um intervalo de dois anos. A tendência de aumento das temperaturas mínimas sugere a presença de diminuição do número de noites frias para os últimos anos da série. Assim, conforme demonstra o Gráfico 8, a reta de tendência aponta para um aumento de $0,47^{\circ} \mathrm{C}$ nos valores das temperaturas mínimas durante os trinta e quatro anos de observação da série considerada, indicando uma estabilidade dessa variável.

O Gráfico 9 mostra que a temperatura média máxima aponta para uma tendência positiva de aumento, à taxa de $0,034^{\circ} \mathrm{C}$ ao ano, contabilizando $1,1^{\circ} \mathrm{C}$ ao longo da série de trinta e quatro anos, para um coeficiente de determinação da reta ajustada aos dados, $\mathrm{R}^{2}=$ 0,1468, muito baixo. Esse valor mostra que a tendência é pouco significativa. A maior TMedMax registrada em 1999 foi de $33,4^{\circ} \mathrm{C}$ e a menor, em 2004 , com valor de $31,1^{\circ} \mathrm{C}$, resultando em uma amplitude térmica de $2,3^{\circ} \mathrm{C}$. 


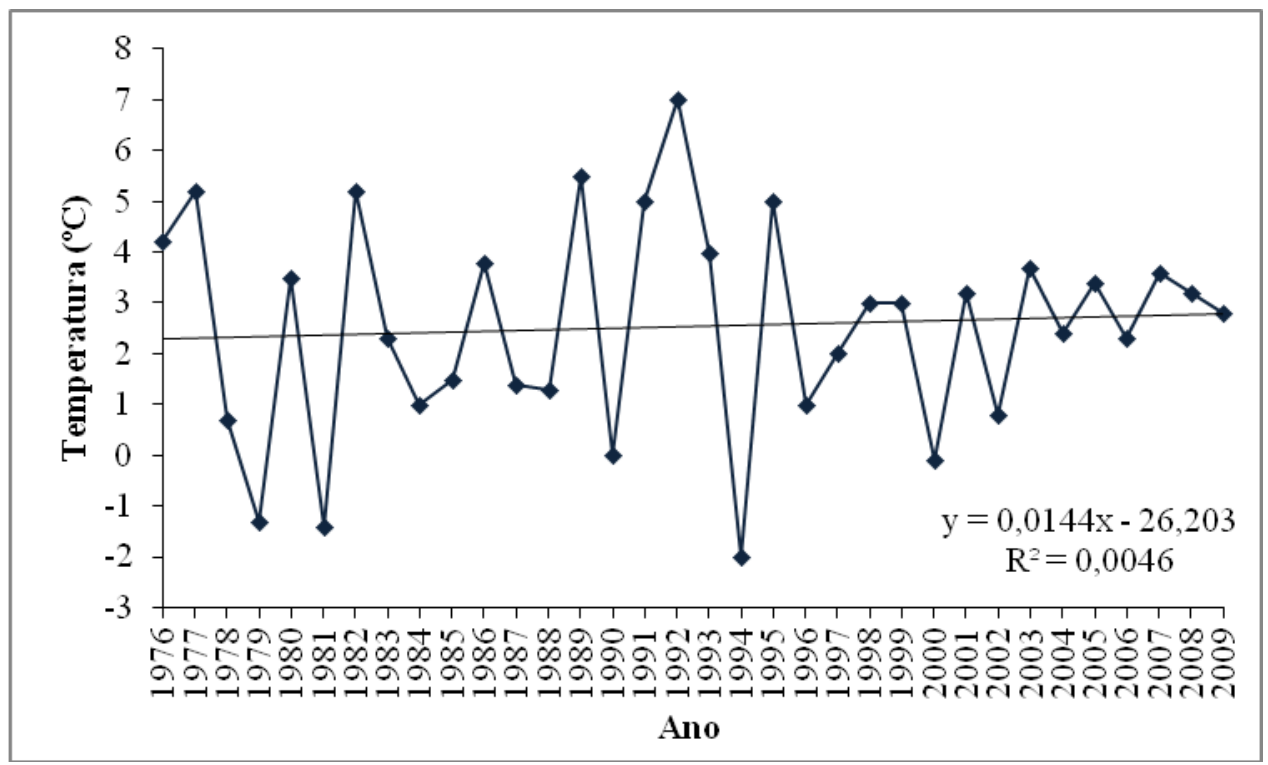

Gráfico 8 - Reta de regressão para a temperatura mínima anual no município de Pirassununga/SP para os anos de 1976 a 2009.

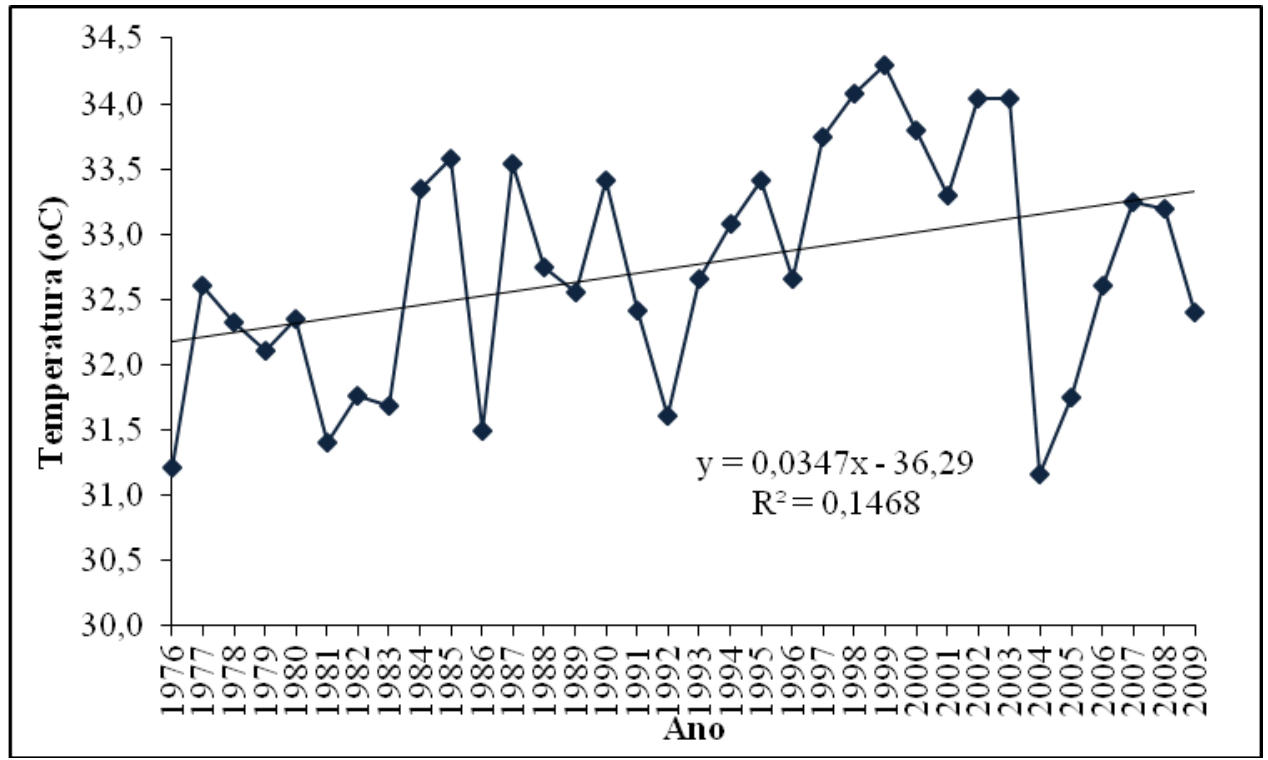

Gráfico 9 - Reta de regressão para a temperatura média máxima anual (TMed Max) no município de Pirassununga/SP para os anos de 1976 a 2009.

A reta de regressão do Gráfico 10 evidencia um pequeno decréscimo nos valores da temperatura média mínima à taxa de $0,013^{\circ} \mathrm{C}$ ao ano, totalizando $0,4^{\circ} \mathrm{C}$ para a série toda, mostrando que a tendência dessa variável é muito pouco significativa, apontando para uma estabilidade da mesma. A maior TMedMin de $12,3^{\circ} \mathrm{C}$ ocorreu em 1977 e a menor, 8,2 $2^{\circ} \mathrm{C}$, em 2004, resultando em uma amplitude térmica de $4,1^{\circ} \mathrm{C}$. Com o valor de $\mathrm{R}^{2}=0,025$ fica evidente que a reta de regressão não foi bem ajustada aos dados. 


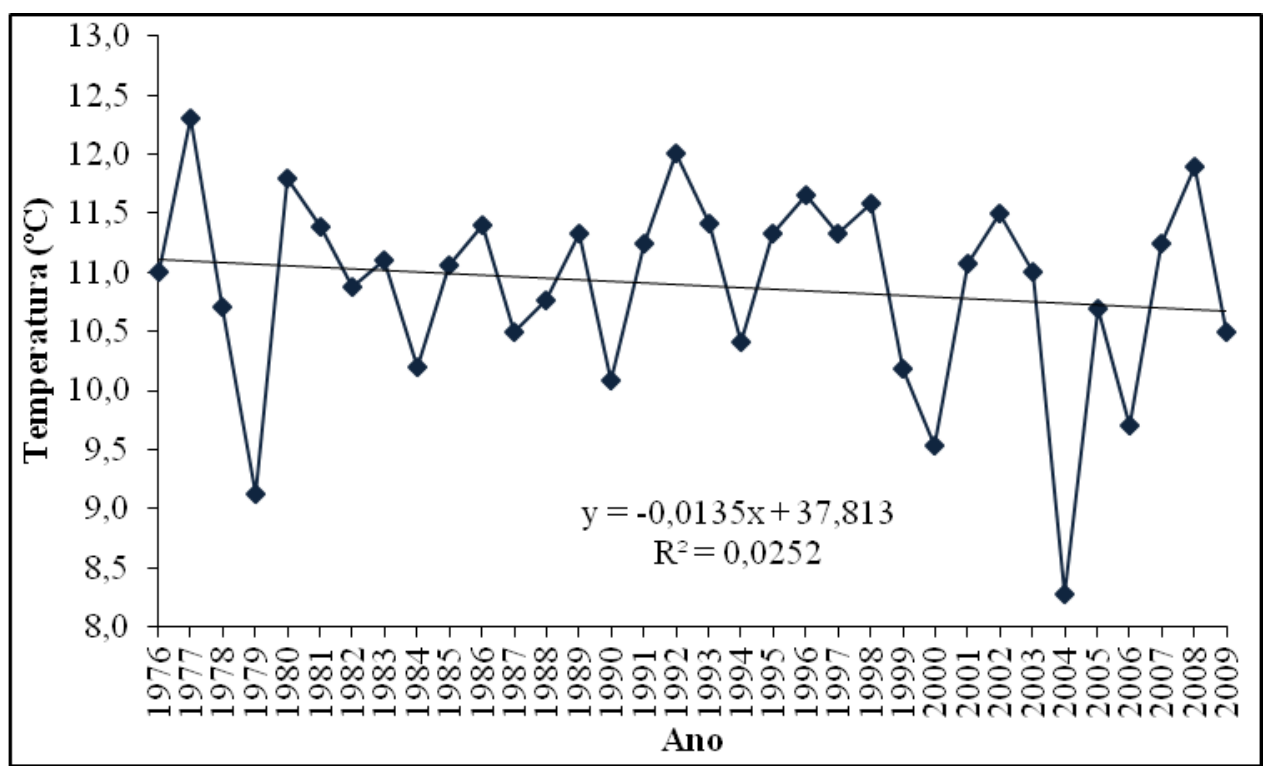

Gráfico 10 - Reta de regressão para a temperatura média mínima anual no município de Pirassununga/SP para os anos de 1976 a 2009.

\subsection{3 - Análise da variabilidade para a pluviosidade}

Ao longo da série temporal estudada (1976 a 2009) registrou-se o total anual médio de 1304,1 mm, sendo 1983 o ano mais chuvoso $(2069,1 \mathrm{~mm})$ e 1994, o menos chuvoso (810,7 mm), conforme Tabela 4.

Tabela 4 - Valores da pluviosidade total anual no município de Pirassununga/SP para os anos de 1976 a 2009.

\begin{tabular}{cccccc}
\hline Ano & Total $(\mathbf{m m})$ & Ano & Total $(\mathbf{m m})$ & Ano & Total $(\mathbf{m m})$ \\
\hline 1976 & 1560,5 & 1988 & 1266,8 & 2000 & 1704,8 \\
1977 & 1227,3 & 1989 & 1389,6 & 2001 & 1157,0 \\
1978 & 1442,3 & 1990 & 1041,5 & 2002 & 1131,2 \\
1979 & 1109,5 & 1991 & 1095,8 & 2003 & 1217,1 \\
1980 & 1367,2 & 1992 & 1054,9 & 2004 & 1402,5 \\
1981 & 1164,4 & 1993 & 1096,3 & 2005 & 897,2 \\
1982 & 1369,3 & 1994 & 810,7 & 2006 & 1291,3 \\
1983 & 2069,1 & 1995 & 1244,7 & 2007 & 1239,6 \\
1984 & 812,0 & 1996 & 1676,9 & 2008 & 1328,8 \\
1985 & 1139,6 & 1997 & 1274,8 & 2009 & 1755,7 \\
1986 & 1876,0 & 1998 & 1462,8 & & \\
1987 & 1440,9 & 1999 & 1220,3 & & \\
\hline
\end{tabular}


A análise da pluviosidade no período escolhido evidencia que sua distribuição não é igualitária ao longo do ano, conforme Tabela 5. Verifica-se, também, a ocorrência de dois a quatro meses sem a incidência de chuvas ao longo da série. As estações com menor precipitação (seca) são, em geral, o outono e o inverno, fato decorrente do clima tropical no qual a região está inserida.

O período que abrange os meses de abril a setembro, em geral, apresenta pluviosidades médias mensais abaixo de $80 \mathrm{~mm}$. Já o período compreendido entre o primeiro trimestre (janeiro, fevereiro e março) e o último (outubro, novembro e dezembro), apresenta valores médios de pluviosidade acima de $100 \mathrm{~mm}$. (Tabela 5).

Tabela 5 - Valores de média, desvio padrão (DP) e coeficiente de variação (CV) da pluviosidade média anual e mensal no município de Pirassununga/SP para os anos de 1976 a 2009.

\begin{tabular}{cccccc}
\hline Anual/mensal & $\begin{array}{c}\text { Média } \\
(\mathbf{m m})\end{array}$ & $\begin{array}{c}\mathbf{D P} \\
(\mathbf{m m})\end{array}$ & $\begin{array}{c}\mathbf{C V} \\
(\mathbf{\%})\end{array}$ & $\begin{array}{c}\text { Max } \\
(\mathbf{m m})\end{array}$ & $\begin{array}{c}\text { Min } \\
(\mathbf{m m})\end{array}$ \\
\hline jan. & 229,5 & 73,1 & 32 & 448,4 & 119,2 \\
fev. & 187,2 & 98,1 & 52 & 418,5 & 9,3 \\
mar. & 143,3 & 70,9 & 49 & 295,6 & 40,9 \\
abr. & 62,1 & 41,9 & 67 & 181,6 & 1,1 \\
maio & 56,7 & 35,4 & 62 & 141,5 & 3 \\
jun. & 26,4 & 30,5 & 115 & 153,5 & 0 \\
jul. & 27,9 & 29,6 & 106 & 126,8 & 0 \\
ago. & 28,7 & 35,2 & 122 & 123,5 & 0 \\
set. & 61,3 & 48,1 & 78 & 193,0 & 0 \\
out. & 110,7 & 60,8 & 55 & 240,1 & 19,4 \\
nov. & 139,6 & 62,7 & 45 & 317,6 & 19,1 \\
dez. & 231,3 & 85,4 & 37 & 424,2 & 91,6 \\
Anual & $\mathbf{1 3 0 4 , 1}$ & $\mathbf{2 9 1 , 9}$ & $\mathbf{1 8}$ & $\mathbf{2 0 6 9 , 1}$ & $\mathbf{8 1 0 , 7}$ \\
\hline
\end{tabular}

A pluviosidade média anual no período de 1976 a 2009 foi de 1304,1 mm, sendo 1983 o ano mais chuvoso, com 2069,1 mm, coincidindo com o período de manifestação do fenômeno El Niño. O ano de 1994 foi o de menor índice de pluviosidade, com 810,7 mm. A grande variabilidade da pluviosidade no período pode ser verificada, observando-se que seus valores oscilaram, principalmente, entre $1000 \mathrm{~mm}$ e $1500 \mathrm{~mm}$, com destaque para o biênio 1983 - 1984, quando a pluviosidade declinou de 2069,1 mm para $812 \mathrm{~mm}$ de um ano para o outro.

Os anos de 1983, 1986, 1996, 2000 e 2009 (Tabela 4) são os muito chuvosos, com uma pluviosidade acima de $1600 \mathrm{~mm}$. No caso de anos menos chuvosos, os de 1984, $1994 \mathrm{e}$ 
2005 são os mais secos, apresentando uma pluviosidade menor que $900 \mathrm{~mm}$, valores muito abaixo da média da série. Em relação à sazonalidade, o trimestre mais chuvoso ocorre nos meses de dezembro, janeiro e fevereiro para Pirassununga, compatível com o que acontece no estado de São Paulo, de acordo com Sant'Anna Netto (1995).

O trimestre menos chuvoso abrange os meses de junho, julho e agosto, com pluviosidade média abaixo dos $30 \mathrm{~mm}$.

Verifica-se, também, que dos trinta e quatro anos de observação, vinte registraram pluviosidade abaixo da média e apenas quatorze, acima, apresentando desvio padrão de 291,9 mm e coeficiente de variação de $18 \%$ ao longo da série (Tabela 5). Os valores estão próximos do esperado para a região e em conformidade com a análise da variabilidade mostrada, em nível global, por Ayoade (1986), em sua obra Introdução à climatologia para os trópicos. A magnitude do desvio padrão mostra uma grande variabilidade na pluviosidade para o local. A Tabela 5 mostra, também, que os meses de maio, junho, julho e agosto apresentam os menores índices pluviométricos, com média de $34,9 \mathrm{~mm}$, sendo o mês de junho o menos chuvoso (26,4 mm). Observa-se, também, que os meses maio, junho, julho e agosto registraram valores da pluviosidade mínima igual a zero ou próximos de zero. As máximas pluviosidades ocorreram nos meses de novembro, dezembro, janeiro, fevereiro e março, com precipitação média de 186,2 $\mathrm{mm}$ para esses meses, verificando-se também as máximas pluviosidades para o meses de janeiro $(448,4 \mathrm{~mm})$ e dezembro $(424,2 \mathrm{~mm})$.

O Gráfico 11 ilustra a distribuição temporal da pluviosidade total anual no município de Pirassununga/SP, no período de 1976 a 2009. Constata-se que o menor valor de pluviosidade no município ocorreu no ano de 1994, com um total anual precipitado abaixo de $1000 \mathrm{~mm}$, ao passo que o maior valor anual precipitado está acima de $2000 \mathrm{~mm}$, registrado em 1983, ressaltando-se a alta variabilidade temporal da precipitação naquela localidade. A pluviosidade anual média nesse período é de 1304,1 mm, valor próximo da normal climatológica, que é de $1352 \mathrm{~mm}$, determinada pelo INMET. 


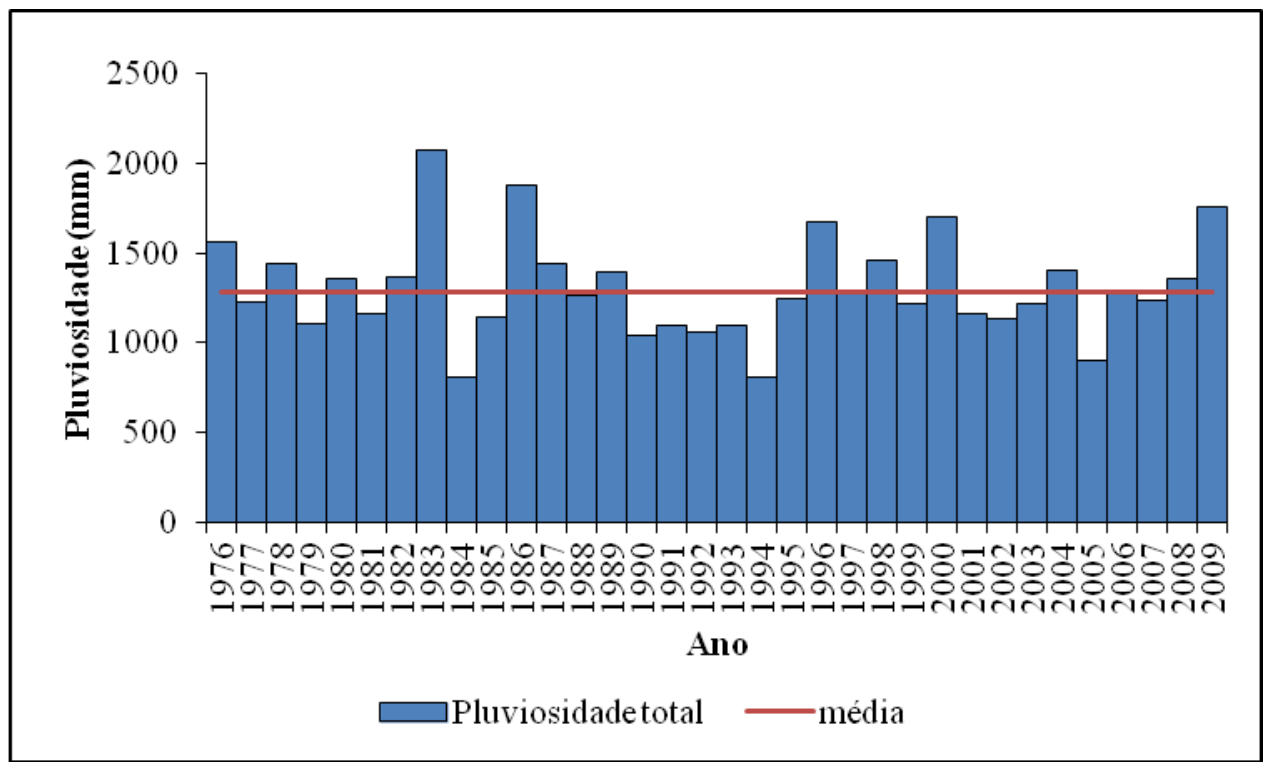

Gráfico 11 - Pluviosidade total anual de Pirassununga/SP de 1976 a 2009.

O polinômio de quinto grau ajustado à série de dados anuais da chuva (Gráfico 12) mostra, também, a grande variabilidade do fenômeno que, durante toda a série retratada, apresentou valores oscilando entre 1000 e 1500 mm, com destaque para o biênio 1983/1984, em que a pluviosidade declinou de $2069,1 \mathrm{~mm}$ para $812,0 \mathrm{~mm}$ de um ano para outro. A análise para períodos mais curtos ao longo da série, evidencia que a curva indica variabilidades decrescentes de 1981 a 1987 e de 1987 a 1994; levemente crescente no período de 1994 a 1996; e acentuadamente crescente no final da série (2005 a 2009).

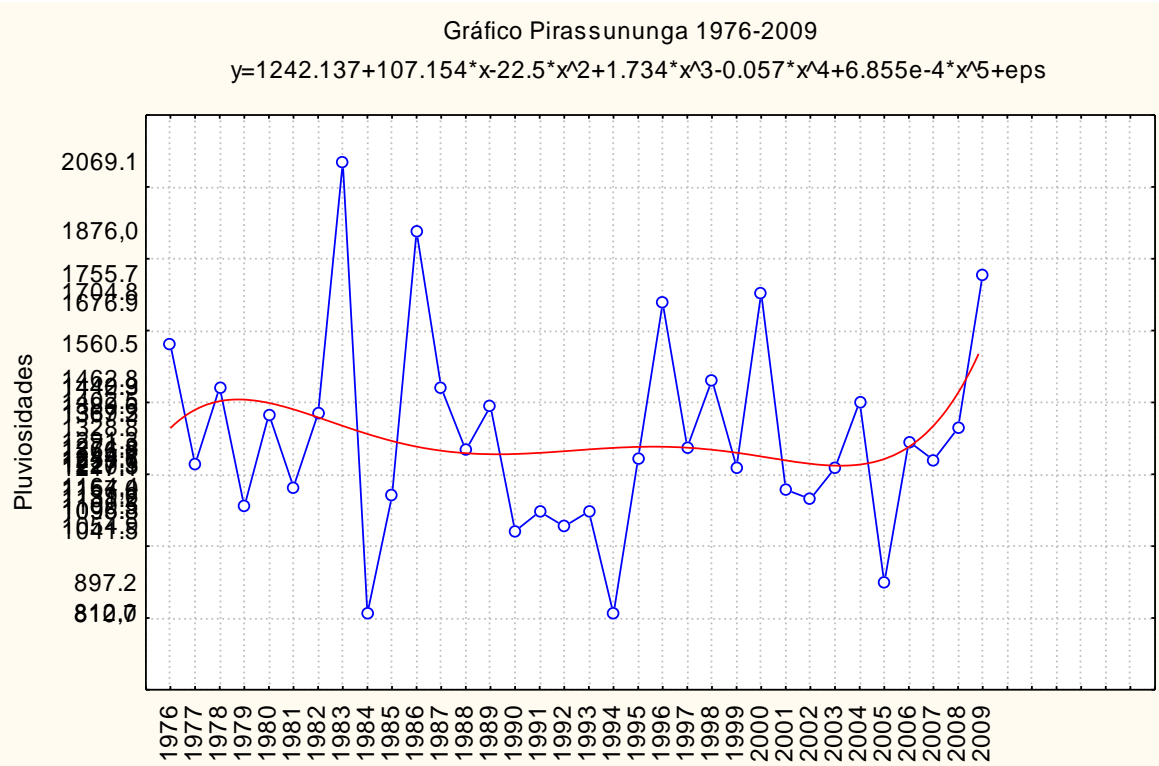

Gráfico 12 - Pluviosidade total anual de Pirassununga/SP de 1976 a 2009, curva de regressão polinomial de grau 5. 
A análise dos dados da série indica que janeiro é o mês da série com o de menor número dias sem chuva (436), com média de 12,8 dias, seguido de fevereiro (465), com média de 13,6 dias e dezembro (476), com média de 14 dias, e julho, o mês com o maior número de dias sem chuva (957), com média de 28,2 dias, seguido de agosto (937), com média de 27,5 dias e junho (904), com média de 26,5 dias. Os dados são apresentados no Anexo D.

A análise de todo o período mostra que dezembro, janeiro e fevereiro são os meses com maior total de pluviosidade: (7865, 7803 e $6364 \mathrm{~mm}$, respectivamente). Esses meses apresentam maior número de dias com pluviosidade, caracterizando o trimestre mais chuvoso da série estudada.

O prosseguimento da análise revela que, os meses de junho, julho e agosto são os com menor pluviosidade (897, 948 e 978 mm, respectivamente), com o menor número de dias com pluviosidade.

É possível observar, também, que ocorre grande variabilidade em relação ao número de dias com chuva ao longo da série: a média de 116,6 dias com chuva mostra que os valores oscilam entre 154 dias, máximo em 1983, ano com maior pluviosidade da série (2069 mm) e 80 dias, mínimo em 1994, ano com menor índice de pluviosidade (810,7 mm).

Um aspecto importante a ser analisado no estudo da variabilidade da pluviosidade é o da "estiagem climatológica", definida como o número de dias por ano sem pluviosidade $\left(\mathrm{n}^{\mathrm{o}} \mathrm{de}\right.$ dias sem chuva/ano). Dessa maneira conclui-se que, para Pirassununga, o ano de maior estiagem climatológica foi 1994, com 285 dias sem chuva, e o de menor estiagem climatológica foi 1983, com 211 dias sem chuva, conforme mostrado no Anexo E.

\subsection{4 - Análise da tendência para a pluviosidade: reta de regressão}

Na análise da tendência, observando os valores da pluviosidade total e a inclinação da reta de regressão, constatou-se uma pequena diminuição de 47,2 $\mathrm{mm}$ ao longo da série (1,38 mm por ano), o que pode ser considerado como manutenção nos valores da pluviosidade no período analisado, conforme Gráfico 13. A análise dos dados não indica qualquer tendência consistente de redução ou aumento das precipitações na localidade. $\mathrm{O}$ valor do coeficiente de determinação $\left(\mathrm{R}^{2}=0,0024\right)$ mostra, também, que nenhuma variação da pluviosidade está associada ao tempo. Pelos dados obtidos, é possível reconhecer que não houve mudança no tipo de clima e que as pequenas mudanças observadas no comportamento 
da pluviosidade, mesmo considerando alguns extremos, estão relacionadas com modificações na frequência e intensidade das massas de ar.

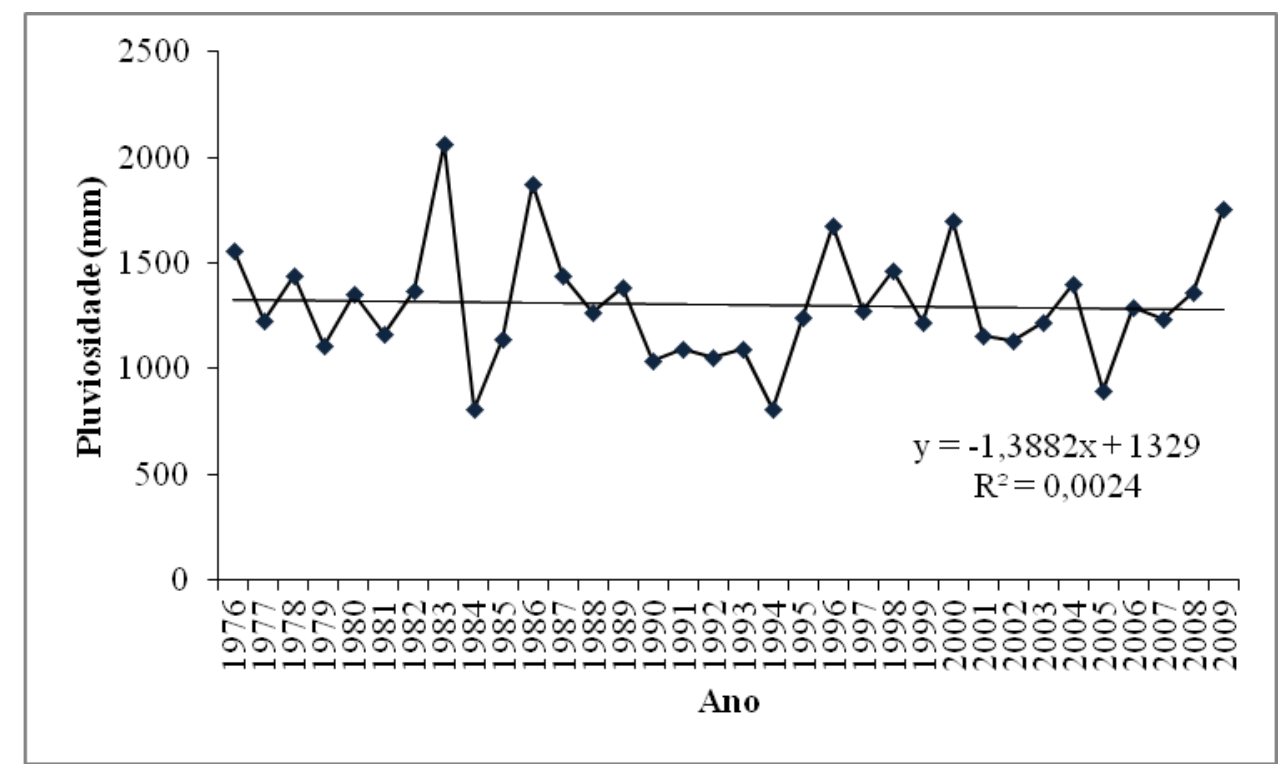

Gráfico 13 - Tendência da pluviosidade total anual no município de Pirassununga/SP no período de 1976 a 2009 - reta de regressão.

\subsection{5 - Análise da tendência para a temperatura e pluviosidade - teste de Mann-Kendall e curvatura de Sen.}

5.1.5.1 - Medidas estatísticas das temperaturas máximas, médias máximas, mínimas, médias mínimas, médias e pluviosidade em Pirassununga no período de 1976-2009.

O objetivo desta seção é estudar os dados anuais, do período entre 1976 a 2009 das variáveis meteorológicas, temperaturas (médias máximas, médias mínimas, mínimas, máximas e médias) e pluviosidade, em Pirassununga-SP. Os resultados envolvem o cálculo de elementos da estatística descritiva, gráficos, ajuste de curvas de regressão polinomial e testes não paramétricos.

Com os dados obtidos foram calculadas as principais medidas estatísticas para verificação da tendência durante o período de 1976-2009 em Pirassununga SP. Para se obterem os cálculos das estatísticas descritivas, tendências e magnitudes dos dados, foram 
utilizados os aplicativos Matlab, Statistica e BioEstat 3.0. As fórmulas para o cálculo dessas medidas podem ser encontradas em Moretin e Bussab (2004).

A Tabela 6 mostra que, para os máximos e mínimos do período, houve uma maior variação nas temperaturas médias mínimas, mínimas e máximas. As médias das temperaturas máximas e médias máximas estão bem próximas. Comportamento similar ocorre com as medidas de variabilidade - desvio padrão (DP) e coeficiente de variação $\mathrm{CV}(\%)$ para as temperaturas dos períodos. Em relação à assimetria, todas as séries são classificadas como assimétricas, sendo as séries das temperaturas máximas e médias assimétricas à esquerda (negativas) e as demais assimétricas à direita (positiva).

Em relação à curtose, todas as distribuições são classificadas como platicúrticas, pois as medidas das colunas são menores que 3 .

Tabela 6 - Medidas estatísticas das temperaturas máximas, médias máximas, mínimas, médias mínimas, médias e pluviosidades de Pirassununga - 1976 a 2009.

\begin{tabular}{|l|c|c|c|c|c|c|}
\hline \multirow{2}{*}{ Estatística } & \multicolumn{7}{|c|}{ Variáveis Meteorológicas } \\
\cline { 2 - 7 } & $\begin{array}{c}\text { temperatura } \\
\text { máxima } \\
\left({ }^{\circ} \mathrm{C}\right)\end{array}$ & $\begin{array}{c}\text { temperatura } \\
\text { média máxima } \\
\left({ }^{\circ} \mathrm{C}\right)\end{array}$ & $\begin{array}{c}\text { temperatura } \\
\text { mínima } \\
\left({ }^{\circ} \mathrm{C}\right)\end{array}$ & $\begin{array}{c}\text { temperatura } \\
\text { média mínima } \\
\left({ }^{\circ} \mathrm{C}\right)\end{array}$ & $\begin{array}{c}\text { temperatura } \\
\text { média } \\
\left({ }^{\circ} \mathrm{C}\right)\end{array}$ & $\begin{array}{c}\text { pluviosidade } \\
(\mathrm{mm})\end{array}$ \\
\hline Mínimo & 33 & 31,16 & $-2,00$ & 1,0700 & 21,10 & 810,70 \\
Máximo & 39,00 & 34,29 & 7,00 & 12,31 & 23,80 & 2069,10 \\
M. A. & 36,24 & 32,75 & 2,53 & 10,74 & 22,65 & 1304,07 \\
DP & 1,52 & 0,89 & 2,10 & 1,88 & 0,62 & 281,00 \\
CV(\%) & 4,20 & 2,75 & 3,16 & 17,78 & 2,7 & 21,55 \\
Assim. & 0,1744 & $-0,1267$ & $-0,2432$ & $-4,1594$ & 0,34 & 0,7081 \\
Curtose & $-0,4429$ & $-1,0166$ & $-0,2119$ & 2,6299 & 0,45 & 0,8102 \\
\hline
\end{tabular}

Onde: M. A. = Média Aritmética; DP = Desvio Padrão; CV = Coeficiente de Variação; Assim. $=$ coeficiente de assimetria; Curtose $=$ Coeficiente de Curtose .

\subsubsection{2 - Análises das tendências e das estimativas}

Na Tabela 7 são apresentados os resultados da aplicação dos testes estatísticos de Mann-Kendall (MK) e Curvatura de Sen (CS), considerando o nível de confiança de $95 \%$ ou $\alpha=5 \%$. 
A seguir são apresentados resultados das análises das variáveis meteorológicas, a partir dos testes estatísticos de Mann-Kendall (MK) e Curvatura de Sen (CS), considerando-se o nível de confiança de $95 \%$ ou $\alpha=5 \%$.

Tabela 7 - Medidas estatísticas de tendência das variáveis meteorológicas $(\alpha=5 \%)$ para Pirassununga/SP - 1976 a 2009.

\begin{tabular}{|l|c|c|c|c|c|c|}
\hline \multirow{2}{*}{ Estatística } & \multicolumn{6}{|c|}{ Variáveis Meteorológicas } \\
\cline { 2 - 7 } & $\begin{array}{c}\text { temperatura } \\
\text { máxima } \\
\left({ }^{\circ} \mathrm{C}\right)\end{array}$ & $\begin{array}{c}\text { temperatura média } \\
\text { máxima } \\
\left({ }^{\circ} \mathrm{C}\right)\end{array}$ & $\begin{array}{c}\text { temperatura } \\
\text { mínimas } \\
\left({ }^{\circ} \mathrm{C}\right)\end{array}$ & $\begin{array}{c}\text { temperatura média } \\
\text { mínima } \\
\left({ }^{\circ} \mathrm{C}\right)\end{array}$ & $\begin{array}{c}\text { temperatura } \\
\text { média } \\
\left({ }^{\circ} \mathrm{C}\right)\end{array}$ & $\begin{array}{c}\text { pluviosidade } \\
(\mathrm{mm})\end{array}$ \\
\hline Escore Z & 2,9013 & 2,1945 & 0,1187 & $-0,3877$ & 0,8943 & 0,5853 \\
MK & 0,3494 & 0,2656 & 0,0160 & $-0,0492$ & 0,1087 & 0,1167 \\
CS & 0,0800 & 0,0393 & 0,0042 & $-0,0065$ & 0,0100 & 6,2654 \\
Prob. (p) & 0,0037 & 0,0282 & 0,9055 & 0,6983 & 0,3711 & 0,5584 \\
\hline
\end{tabular}

A partir dessa tabela, é possível estabelecer que:

1. Para os resultados da coluna das temperaturas máximas e coluna das temperaturas médias máximas há uma tendência de 0,3494 e 0,2656 (Mann-Kendall), crescente ou positiva, pois $\mathrm{Z}>0$, sendo significante, pois $p<\alpha$ e que essas temperaturas aumentam aproximadamente $0,0800^{\circ} \mathrm{C}$ e $0,0393^{\circ} \mathrm{C}$ por ano, respectivamente (Curvatura de Sen).

2. Para os resultados da coluna das temperaturas médias mínimas, há uma tendência de $-0,0492$, fracamente decrescente ou negativa, pois $Z<0$, sendo insignificante, pois $p=0,6983>\alpha=0,05$, com uma diminuição de aproximadamente $0,0065^{\circ} \mathrm{C}$ por ano;

3. Para os resultados das colunas das temperaturas mínimas, médias e pluviosidades, há tendências crescentes, pois $\mathrm{Z}>0$, mas mostrando-se insignificante, pois $p>\alpha$, e que aumentam aproximadamente $0,0042^{\circ} \mathrm{C} ; 0,0100^{\circ} \mathrm{C}$ e $6,2654 \mathrm{~mm}$ por ano.

As análises de regressão linear para os dados das temperaturas médias máximas e temperaturas máximas de Pirassununga 1976-2009 foram apresentadas nos Gráfico 7 e Gráfico 9 que, considerando os resultados da Tabela 7, detectou tendências significativas para as estatísticas de Mann-Kendall e curvatura de Sen dessas variáveis em estudo.

Os valores das magnitudes das tendências das temperaturas máximas e média máximas mostraram-se coerentes, quando comparados com os resultados obtidos pela reta de regressão e Curvatura de Sen. Observando o Gráfico 7 verifica-se que o coeficiente angular da reta de regressão para a temperatura máxima é igual a 0,079, indicando uma tendência de acréscimo de $0,079^{\circ} \mathrm{C}$ por ano para a série estudada. De acordo com a coluna 1 da Tabela 7, o valor da magnitude da tendência calculada pela Curvatura de Sen é igual a 0,0800, 
indicando uma tendência crescente à taxa de $0,08^{\circ} \mathrm{C}$ por ano e evidenciando resultados praticamente iguais, determinados por dois métodos diferentes.

O mesmo ocorre com a reta de regressão para a temperatura média máxima (Gráfico 9), que mostra um coeficiente angular igual a 0,034, indicando uma tendência de aumento de $0,034^{\circ} \mathrm{C}$ ao ano. A coluna 2 da Tabela 7 mostra o valor de 0,039 , medido pelo estimador estatístico da Curvatura de Sen, indicando uma tendência crescente com magnitude de $0,039^{\circ} \mathrm{C}$ ao ano, novamente com resultados praticamente iguais.

De acordo com a análise do item 3, a tendência da pluviosidade mostrou-se insignificante (aumento de 6,2 $\mathrm{mm}$ ao ano), o que permite concluir que não foi encontrada tendência significativa na variável precipitação, analisada com teste Mann-Kendall.

Em relação à coluna da temperatura mínima da Tabela 7, as medidas estatísticas Z>0, mas insignificante, pois $p>\alpha(0,9055)$, obtidas do teste de Mann-Kendall, indica que essa variável tem tendência crescente com magnitude da ordem de aproximadamente $0,0042^{\circ} \mathrm{C}$ ao ano, medida pelo estimador estatístico da Curvatura de Sen. Para essa mesma variável, a reta de tendência do Gráfico 8 determina um coeficiente angular igual a 0,014, indicando um pequeno crescimento de $0,014^{\circ} \mathrm{C}$ ao ano. Nesse caso, as medidas estatísticas apresentam resultados diferentes: a magnitude da tendência medida pela Curvatura de Sen é aproximadamente quatro vezes menor que a medida pela reta de regressão.

Comparativamente, a análise da tendência feita por meio da reta de regressão em relação ao teste de MK é menos indicada porque o ajuste da reta aos dados nem sempre é adequado, já que resulta em uma medida estatística pouco representativa, enquanto o teste MK considera que, em uma série temporal, a sucessão de valores ocorre de forma independente e a distribuição de probabilidade deve permanecer sempre a mesma, caracterizando uma série aleatória simples.

Além disso a análise de regressão é utilizada para indicar alterações climáticas por meio da significância do coeficiente angular de uma reta ajustada aos dados, enquanto o teste MK considera a diferença entre a probabilidade de que os dados observados de duas variáveis estejam na mesma ordem, contra a probabilidade de que os mesmos dados estejam em ordens diferentes para as referidas variáveis.

Conceitualmente, a análise de regressão é denominada método paramétrico por assumir que a amostra pode ser ajustada a uma distribuição teórica. O teste MK não faz distinção quanto à distribuição que os dados são oriundos, sendo, com isso, considerado nãoparamétrico. Assim, esse método é fundamentalmente desenvolvido para a detecção de tendências climáticas em uma série temporal. 
5.2 - Análise dos dados de temperatura e pluviosidade da série temporal de 1994 a 2009 para Pirassununga/SP.

\subsection{1 - Análise da variabilidade da temperatura}

\subsubsection{1 - Temperatura média}

A Tabela 8 sobre o comportamento anual da temperatura durante a série temporal considerada (1994-2009) mostra que a temperatura média anual do período é de $22,6^{\circ} \mathrm{C}$. A temperatura média mais elevada foi de $23,3^{\circ} \mathrm{C}$, registrada em 1998 , e a média mais baixa, de $20,4^{\circ} \mathrm{C}$, em 2004 , com uma pequena amplitude térmica de $2,9^{\circ} \mathrm{C}$.

Tabela 8 - Valores da temperatura média anual no município de Pirassununga/SP para a série temporal de 1994 a 2009.

\begin{tabular}{cc}
\hline Ano & T média $\left({ }^{\mathbf{0}} \mathbf{C}\right)$ \\
\hline 1994 & 23,2 \\
1995 & 22,9 \\
1996 & 22,5 \\
1997 & 23,2 \\
1998 & 23,3 \\
1999 & 22,7 \\
2000 & 23,2 \\
2001 & 22,8 \\
2002 & 22,7 \\
2003 & 21,7 \\
2004 & 20,4 \\
2005 & 21,5 \\
2006 & 21,3 \\
2007 & 22,5 \\
2008 & 21,8 \\
2009 & 21,4 \\
Med & $\mathbf{2 2 , 6}$ \\
\hline
\end{tabular}

Quanto ao comportamento mensal dessa variável, a Tabela 9 mostra que o primeiro e o último trimestres do ano representam o período de temperaturas mais elevadas, sendo fevereiro o mês mais quente do ano, com média mensal de $25,1^{\circ} \mathrm{C}$, desvio padrão de $1,2^{\circ} \mathrm{C}$, 
coeficiente de variação de $4,74 \%$, temperatura média máxima igual a $27,1^{\circ} \mathrm{C}$ e também temperatura média mínima de $23,3^{\circ} \mathrm{C}$ (maior temperatura média mínima da série). Já os meses de maio, junho, julho e agosto representam o período do ano com temperaturas menos elevadas, sendo junho o mês mais frio, com temperatura média de $18,5^{\circ} \mathrm{C}$, desvio padrão de $1,1^{\circ} \mathrm{C}$, coeficiente de variação de $5,9 \%$ e temperatura média máxima de $20,7^{\circ} \mathrm{C}$. Abril é o mês com maior coeficiente de variação $(\mathrm{CV}=9,3 \%)$, mostrando a maior variabilidade da temperatura média do ar para a série; e o mês com menor coeficiente de variação é dezembro $(\mathrm{CV}=4 \%)$, com pouca variabilidade, ou seja, a temperatura manteve-se próxima de um valor constante para todos os meses de dezembro da série.

Tabela 9 - Valores da temperatura média, desvio padrão (DP) e coeficiente de variação (CV) da temperatura média anual e mensal no município de Pirassununga/SP para os anos de 1994 a 2009.

\begin{tabular}{cclccc}
\hline Anual/mensal & $\begin{array}{c}\text { Média } \\
\left({ }^{\mathbf{}} \mathbf{C}\right)\end{array}$ & $\begin{array}{c}\text { DP } \\
\left(\mathbf{}{ }^{\mathbf{C}}\right)\end{array}$ & $\begin{array}{c}\mathbf{C V} \\
(\mathbf{\%})\end{array}$ & $\begin{array}{c}\text { MaxMed } \\
\left({ }^{\mathbf{}} \mathbf{C}\right)\end{array}$ & $\begin{array}{c}\text { MinMed } \\
\left({ }^{\mathbf{O}} \mathbf{C}\right)\end{array}$ \\
\hline Jan & 24,9 & 1,1 & 4,4 & 27,0 & 23,2 \\
Fev & 25,1 & 1,2 & 4,7 & 27,1 & 23,3 \\
Mar & 24,6 & 1,2 & 4,8 & 26,5 & 22,4 \\
Abr & 22,6 & 2,1 & 9,3 & 25,7 & 16,9 \\
Mai & 19,4 & 1,2 & 6,2 & 21,3 & 17,1 \\
Jun & 18,5 & 1,1 & 5,9 & 20,7 & 16,9 \\
Jul & 18,7 & 1,4 & 7,5 & 21,5 & 16,3 \\
Ago & 21,1 & 1,4 & 6,6 & 23,2 & 18,9 \\
Set & 22,9 & 1,2 & 5,2 & 25,1 & 20,8 \\
Out & 24,7 & 1,6 & 6,4 & 27,5 & 21,1 \\
Nov & 24,5 & 1,0 & 4,1 & 26,5 & 23,1 \\
Dez & 24,9 & 1,0 & 4 & 26,4 & 22,7 \\
anual & $\mathbf{2 2 , 6}$ & $\mathbf{0 , 7}$ & $\mathbf{3 , 1}$ & $\mathbf{2 3 , 8}$ & $\mathbf{2 1 , 1}$ \\
\hline
\end{tabular}

A análise da distribuição dessa variável climática ao longo da série (Gráfico 14) evidencia que dos dezesseis anos, dez apresentaram temperatura média anual, acima da média da série, sendo que os últimos sete da série apontam para uma diminuição dos valores médios, verificando-se o desvio padrão de $0,7^{\circ} \mathrm{C}$ e o coeficiente de variação de $3,1 \%$, conforme a Tabela 9. O Gráfico 14 mostra também que a temperatura média apresentou pequena variabilidade. Nos últimos sete anos, mesmo com um valor extremo e inferior à média, em 1994, os valores registrados para os últimos anos foram bem próximos do valor médio. Podese constatar, ainda, que os últimos sete anos da série foram um pouco mais frios que os anteriores, com temperaturas abaixo da média 


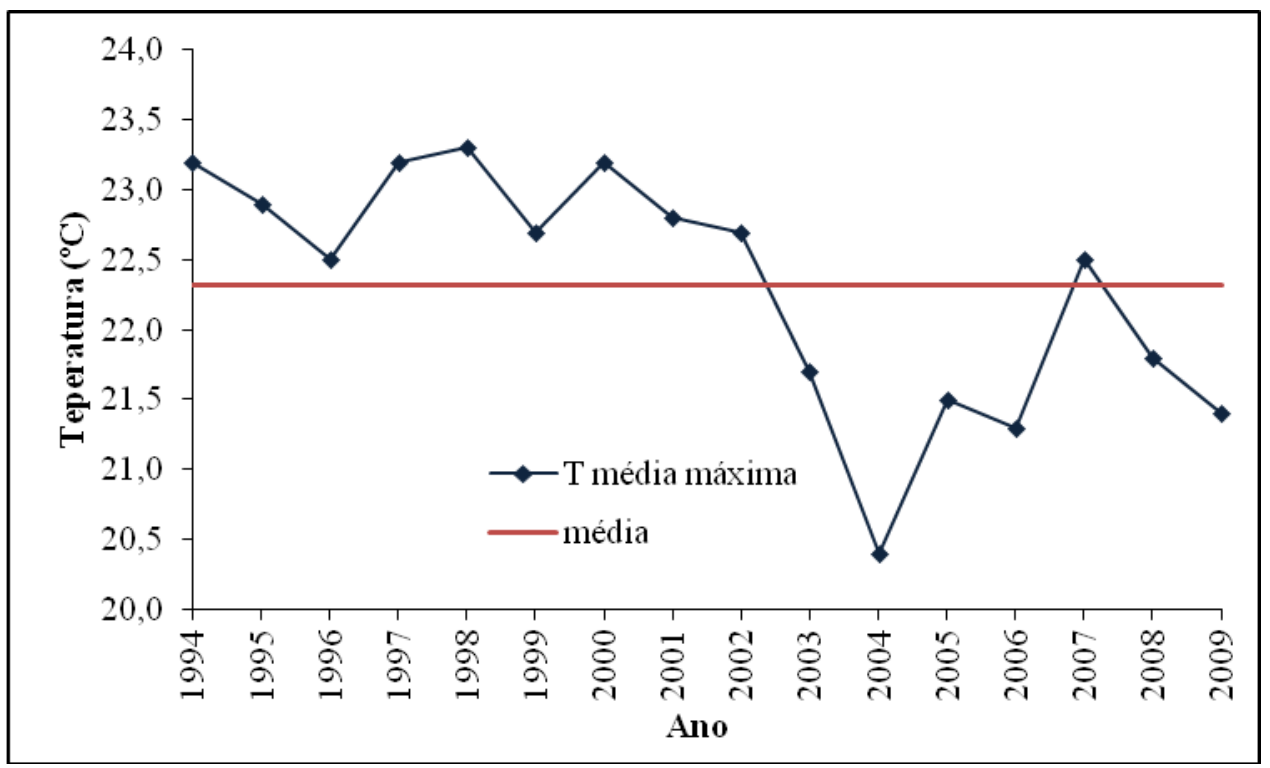

Gráfico 14 - Temperatura média anual no município de Pirassununga/SP para os anos de 1994 a 2009.

\subsubsection{2 - Temperatura máxima}

De acordo com a Tabela 10 verifica-se que a média das temperaturas máximas para o período é de $37,1^{\circ} \mathrm{C}$. A maior temperatura máxima, $39^{\circ} \mathrm{C}$, ocorreu nos anos de 1997 e 2008 e a menor máxima é de $34,8^{\circ} \mathrm{C}$, em 2003 . A amplitude térmica desse período resultou em $4,2^{\circ} \mathrm{C}$, indicando pouca variabilidade anual das temperaturas máximas, com valores oscilando em torno da média.

Em relação ao comportamento mensal da temperatura máxima da Tabela 11, verificase que os valores dessa variável mostraram que outubro é o mês mais quente da série, com temperatura média máxima de $36,4^{\circ} \mathrm{C}$, máxima de $39^{\circ} \mathrm{C}$ e mínima máxima de $33^{\circ} \mathrm{C}$, com um desvio padrão de $1,9^{\circ} \mathrm{C}$ e coeficiente de variação de 5,2\%. Na mesma linha de análise, o mês de junho é o mais frio, com temperatura média máxima de $29,2^{\circ} \mathrm{C}$, mínima máxima de $26,3^{\circ} \mathrm{C}$, desvio padrão de $1,7^{\circ} \mathrm{C}$ e coeficiente de variação de $5,8 \%$. A amplitude térmica de $7,2^{\circ} \mathrm{C}\left(36,4^{\circ} \mathrm{C}-29,2^{\circ} \mathrm{C}\right)$, aponta para uma grande variabilidade climática entre os meses do período considerado. 
Tabela 10 - Valores da temperatura máxima anual no município de Pirassununga/SP para a série temporal de 1994 a 2009.

\begin{tabular}{lc}
\hline Ano & Tmáx $\left({ }^{\mathbf{0}} \mathbf{C}\right)$ \\
\hline 1994 & 37 \\
1995 & 36 \\
1996 & 35 \\
1997 & 39 \\
1998 & 36 \\
1999 & 37,1 \\
2000 & 37,6 \\
2001 & 35,5 \\
2002 & 38,9 \\
2003 & 38,4 \\
2004 & 35,7 \\
2005 & 34,8 \\
2006 & 37,5 \\
2007 & 36,4 \\
2008 & 39 \\
2009 & 38,7 \\
Med & $\mathbf{3 7 , 1}$ \\
\hline
\end{tabular}

Tabela 11 - Valores da temperatura máxima, desvio padrão (DP) e coeficiente de variação (CV) da temperatura máxima anual e mensal no município de Pirassununga/SP para os anos de 1994 a 2009.

\begin{tabular}{cccccc}
\hline Anual/mensal & $\begin{array}{c}\text { Méd Max } \\
\left({ }^{\mathbf{0}} \mathbf{C}\right)\end{array}$ & $\begin{array}{c}\text { DP } \\
\left({ }^{\mathbf{0}} \mathbf{C}\right)\end{array}$ & $\begin{array}{c}\mathbf{C V} \\
(\mathbf{\%})\end{array}$ & $\begin{array}{c}\text { MaxMax } \\
\left({ }^{\mathbf{9}} \mathbf{C}\right)\end{array}$ & $\begin{array}{c}\text { MinMax } \\
\left({ }^{\mathbf{}} \mathbf{C}\right)\end{array}$ \\
\hline Jan & 33,9 & 1,6 & 4,7 & 36 & 31,3 \\
Fev & 34,0 & 1,2 & 3,5 & 35,6 & 31,5 \\
Mar & 33,8 & 1,4 & 4,1 & 36,8 & 32,0 \\
Abr & 32,2 & 1,4 & 4,3 & 34,1 & 29,4 \\
Mai & 30,5 & 1,4 & 4,5 & 32,4 & 28,0 \\
Jun & 29,2 & 1,7 & 5,8 & 32,0 & 26,3 \\
Jul & 30,4 & 1,5 & 4,9 & 32,4 & 27,2 \\
Ago & 33,2 & 1,0 & 3,0 & 35,0 & 31,2 \\
Set & 34,8 & 3,0 & 8,6 & 38,4 & 25,7 \\
Out & 36,4 & 1,9 & 5,2 & 39,0 & 33,0 \\
Nov & 34,9 & 1,4 & 4,0 & 38,0 & 32,2 \\
Dez & 34,2 & 1,6 & 4,6 & 37,1 & 31,1 \\
Anual & $\mathbf{3 3 , 2}$ & $\mathbf{0 , 8}$ & $\mathbf{2 , 4}$ & $\mathbf{3 4 , 3}$ & $\mathbf{3 1 , 4}$ \\
\hline
\end{tabular}


A distribuição da temperatura máxima ao longo da série, conforme o Gráfico 15, mostra registros de oito valores abaixo da média $\left(37,1^{\circ} \mathrm{C}\right)$ e oito acima da média $(50 \%)$, indicando uma distribuição simétrica em torno da média, com desvio padrão de $0,8^{\circ} \mathrm{C}$ e coeficiente de variação de $2,4 \%$, valores muito próximos dos encontrados para a temperatura média.

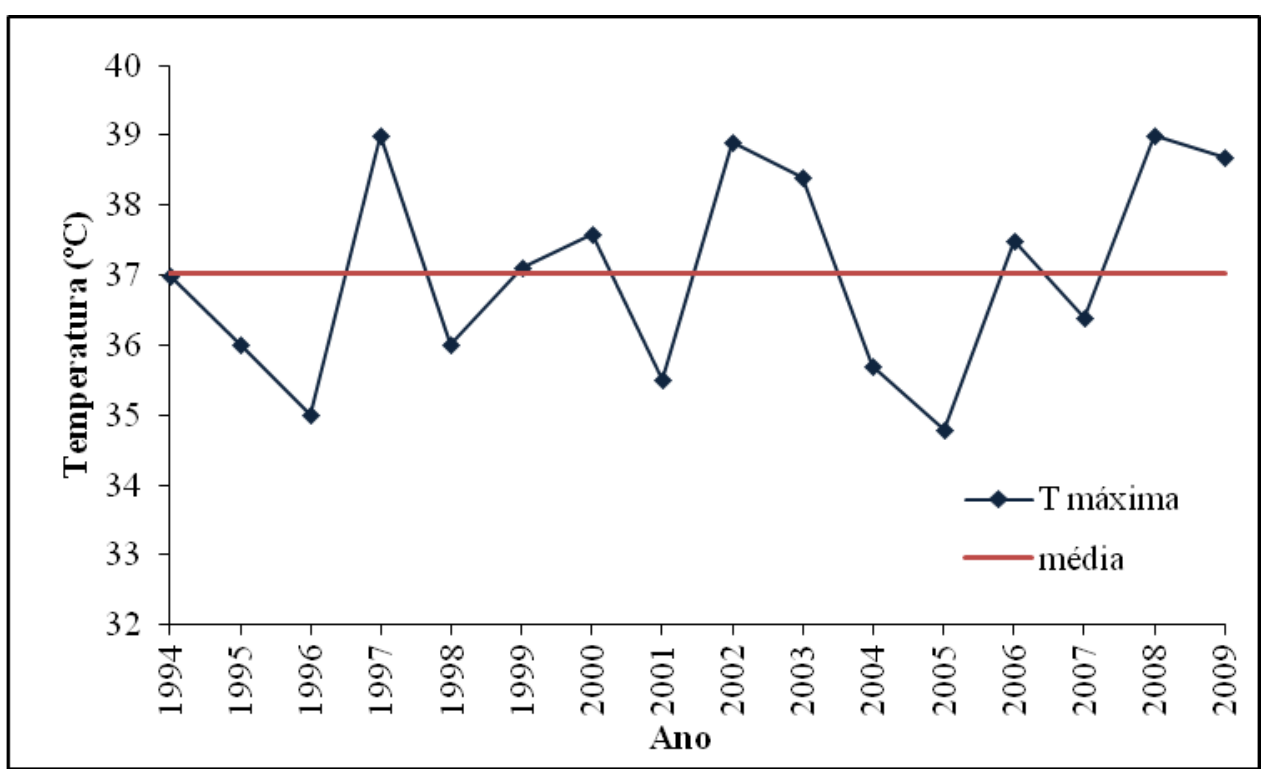

Gráfico 15 - Temperatura máxima anual no município de Pirassununga/SP para os anos de 1994 a 2009.

\subsubsection{3 - Temperatura mínima}

Em relação aos dados da Tabela 12, verifica-se que a média das temperaturas mínimas é de $2,3^{\circ} \mathrm{C}$. A menor temperatura mínima é de $-2^{\circ} \mathrm{C}$, registrada em 1994 e a maior ocorreu em 1995 , com valor registrado de $5^{\circ} \mathrm{C}$, determinando uma amplitude térmica de $7^{\circ} \mathrm{C}$ de um ano para o outro, indicativo de uma média variabilidade para a temperatura mínima anual. 
Tabela 12 - Valores da temperatura mínima anual no município de Pirassununga/SP para a série temporal de 1994 a 2009.

\begin{tabular}{cc}
\hline Ano & Tmin $\left({ }^{\mathbf{C}} \mathbf{)}\right.$ \\
\hline 1994 & $-2,0$ \\
1995 & 5,0 \\
1996 & 1,0 \\
1997 & 2,0 \\
1998 & 3,0 \\
1999 & 3,0 \\
2000 & $-0,1$ \\
2001 & 3,2 \\
2002 & 0,8 \\
2003 & 3,7 \\
2004 & 2,4 \\
2005 & 3,4 \\
2006 & 2,3 \\
2007 & 3,6 \\
2008 & 3,2 \\
2009 & 2,8 \\
Med & $\mathbf{2 , 3}$
\end{tabular}

A análise dos dados mensais colocados na Tabela 13 evidencia que os valores indicam o mês de janeiro com o mais quente da série, com temperatura média mínima, de $17,1^{\circ} \mathrm{C}$, máxima de $19^{\circ} \mathrm{C}$ e mínima de $15^{\circ} \mathrm{C}$, apresentando um desvio padrão de $1,2^{\circ} \mathrm{C}$ e coeficiente de variação de 7\%. Os meses de junho e julho, com valores bem próximos, mostraram-se os mais frios, com temperaturas médias mínimas de $3,9^{\circ} \mathrm{C}$ e $3,4^{\circ} \mathrm{C}$, respectivamente; com máximas de $8,6^{\circ} \mathrm{C}$ e $9^{\circ} \mathrm{C}$ e mínimas de $-2^{\circ} \mathrm{C}$ e $-0,1^{\circ} \mathrm{C}$, respectivamente. Os desvios-padrão tiveram valores iguais $\left(2,5^{\circ} \mathrm{C}\right)$ e os coeficientes de variação apresentando valores de $64,1 \%$ e $73,5 \%$, respectivamente, indicando uma grande variabilidade térmica para esses dois meses. A amplitude térmica da temperatura média mínima é igual a $13,7^{\circ} \mathrm{C}$ $\left(17,1^{\circ} \mathrm{C}-3,4^{\circ} \mathrm{C}\right)$, indicando uma grande variabilidade climática dessa variável entre os meses de janeiro e julho. 
Tabela 13 - Valores da temperatura mínima, desvio padrão (DP) e coeficiente de variação (CV) da temperatura máxima anual e mensal no município de Pirassununga/SP para os anos de 1994 a 2009.

\begin{tabular}{cccccc}
\hline Anual/mensal & $\begin{array}{c}\text { Méd Min } \\
\left({ }^{\mathbf{0}} \mathbf{C}\right)\end{array}$ & $\begin{array}{c}\text { DP } \\
\left({ }^{\mathbf{0}} \mathbf{C}\right)\end{array}$ & $\begin{array}{c}\mathbf{C V} \\
(\mathbf{\%})\end{array}$ & $\begin{array}{c}\text { MaxMin } \\
\left({ }^{\mathbf{}} \mathbf{C}\right)\end{array}$ & $\begin{array}{c}\text { MinMin } \\
\left({ }^{\mathbf{0}} \mathbf{C}\right)\end{array}$ \\
\hline jan & 17,1 & 1,2 & 7 & 19,0 & 15,0 \\
fev & 16,6 & 1,7 & 10,2 & 18,5 & 12,5 \\
mar & 15,3 & 1,5 & 9,8 & 17,8 & 12,0 \\
abr & 10,6 & 2,6 & 24,5 & 14,9 & 5,0 \\
mai & 5,6 & 2,4 & 42,8 & 9,0 & 1,5 \\
jun & 3,9 & 2,5 & 64,1 & 8,6 & $-2,0$ \\
jul & 3,4 & 2,5 & 73,5 & 9,0 & $-0,1$ \\
ago & 6,7 & 2,5 & 37,3 & 12,3 & 3,7 \\
set & 8,5 & 2,4 & 28,2 & 12,0 & 3,2 \\
out & 12,6 & 2,1 & 16,6 & 15,0 & 7,3 \\
nov & 13,7 & 1,6 & 11,6 & 16,3 & 11,0 \\
dez & 15,2 & 1,8 & 11,8 & 18,0 & 12,2 \\
Anual & $\mathbf{1 0 , 8}$ & $\mathbf{0 , 9}$ & $\mathbf{8 , 3}$ & $\mathbf{1 1 , 9}$ & $\mathbf{8 , 6}$ \\
\hline
\end{tabular}

A análise do Gráfico 16 mostra, que com exceção dos dois primeiros anos da série, em que a temperatura mínima variou de $-2^{\circ} \mathrm{C}$ até $5^{\circ} \mathrm{C}$, valores extremos, os anos seguintes (1996 até 2002) apresentaram uma variabilidade um pouco menos acentuada. Para os últimos sete anos da série a variabilidade foi insignificante, com valores um pouco acima da média.

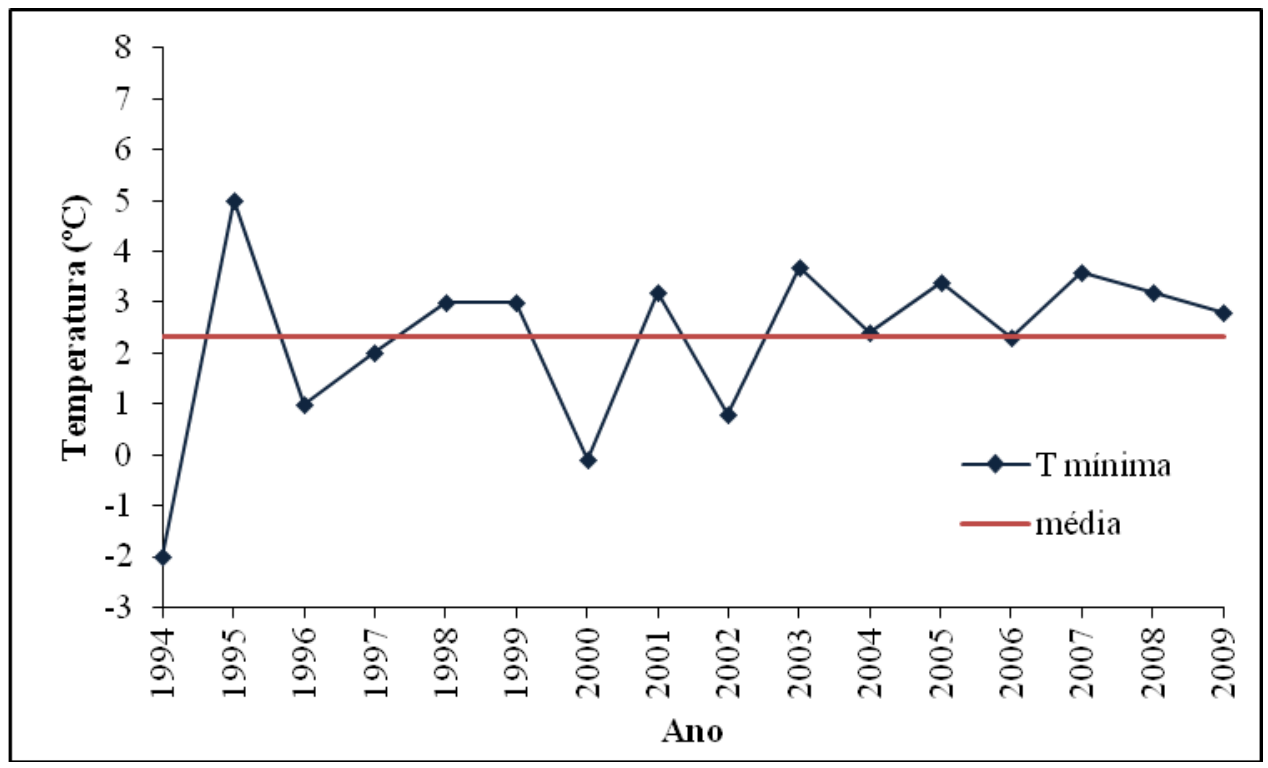

Gráfico 16 - Temperatura mínima anual, no município de Pirassununga/SP para os anos de 1994 a 2009. 


\subsubsection{4 - Temperatura média máxima}

Sobre o comportamento anual da TMedMax é possível verificar a inexistência de variabilidade estatística significativa para o período 1994-2009. De acordo com o Gráfico 17, a média para o período é de $33,2^{\circ} \mathrm{C}$, com máxima de $34,3^{\circ} \mathrm{C}$ em 1999 e a mínima de $31,2^{\circ} \mathrm{C}$ em 2004, indicando uma estabilidade térmica para essa variável.

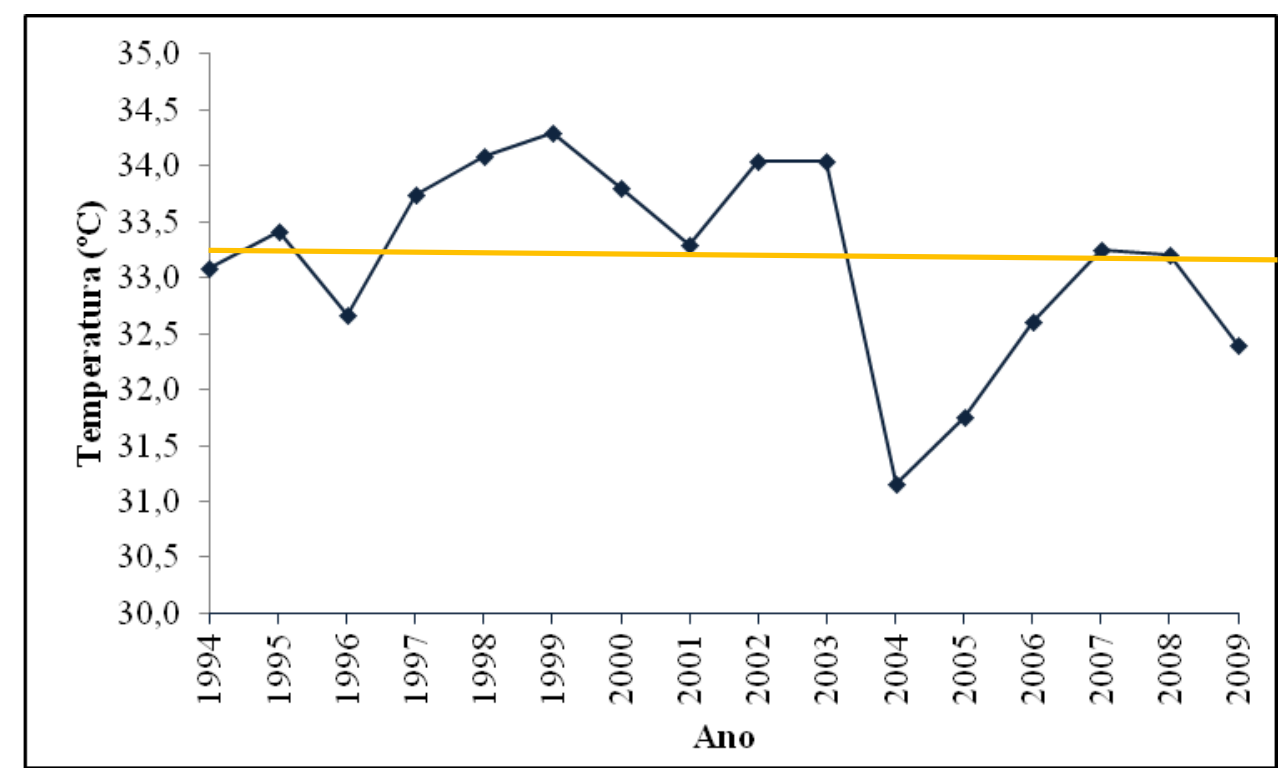

Gráfico 17 - Média das temperaturas máximas anual (TMedMax) no município de Pirassununga/SP para os anos de 1994 a 2009.

\subsubsection{5 - Temperatura média mínima}

Durante o período, a TMedMin oscilou entre os valores de $11,9^{\circ} \mathrm{C}$ em 2 e $8,3^{\circ} \mathrm{C}$ em 2004 , com uma média de $10,7^{\circ} \mathrm{C}$ para o período, observando-se baixa variabilidade para a série (Gráfico 18). 


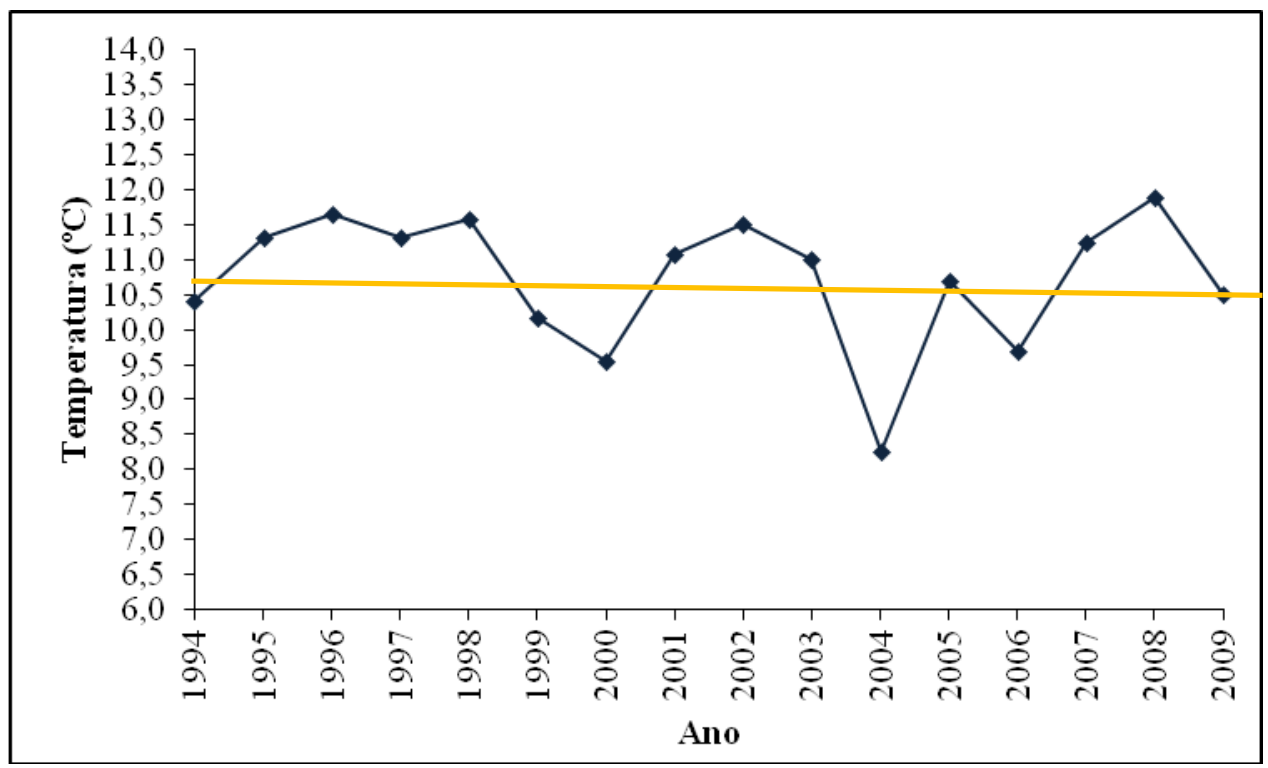

Gráfico 18 - Média das temperaturas mínimas anual (TMedMin) no município de Pirassununga/SP, para os anos de 1994 a 2009.

\subsection{2 - Análise da tendência para as temperaturas médias, máximas, mínimas, média máxima e média mínima: retas de regressão.}

A temperatura média para o período apresenta uma tendência de decrescimento correspondente a $0,128^{\circ} \mathrm{C} /$ ano. $\mathrm{O}$ ano de 1998 , com temperatura média de $23,4^{\circ} \mathrm{C}$, foi o mais quente, enquanto 2004, com temperatura de $20,4^{\circ} \mathrm{C}$, mostrou-se o mais frio, com uma amplitude térmica de $3^{\circ} \mathrm{C}$ para o período. O coeficiente de determinação é igual a 0,502 , explicando que a reta da temperatura média em relação ao tempo se ajusta em 50,2\%, como mostra o Gráfico 19 que apresenta a reta de tendência apontando para um decréscimo de aproximadamente $2,1^{\circ} \mathrm{C}$ na temperatura média anual durante o período de dezesseis anos de observação da série considerada. 


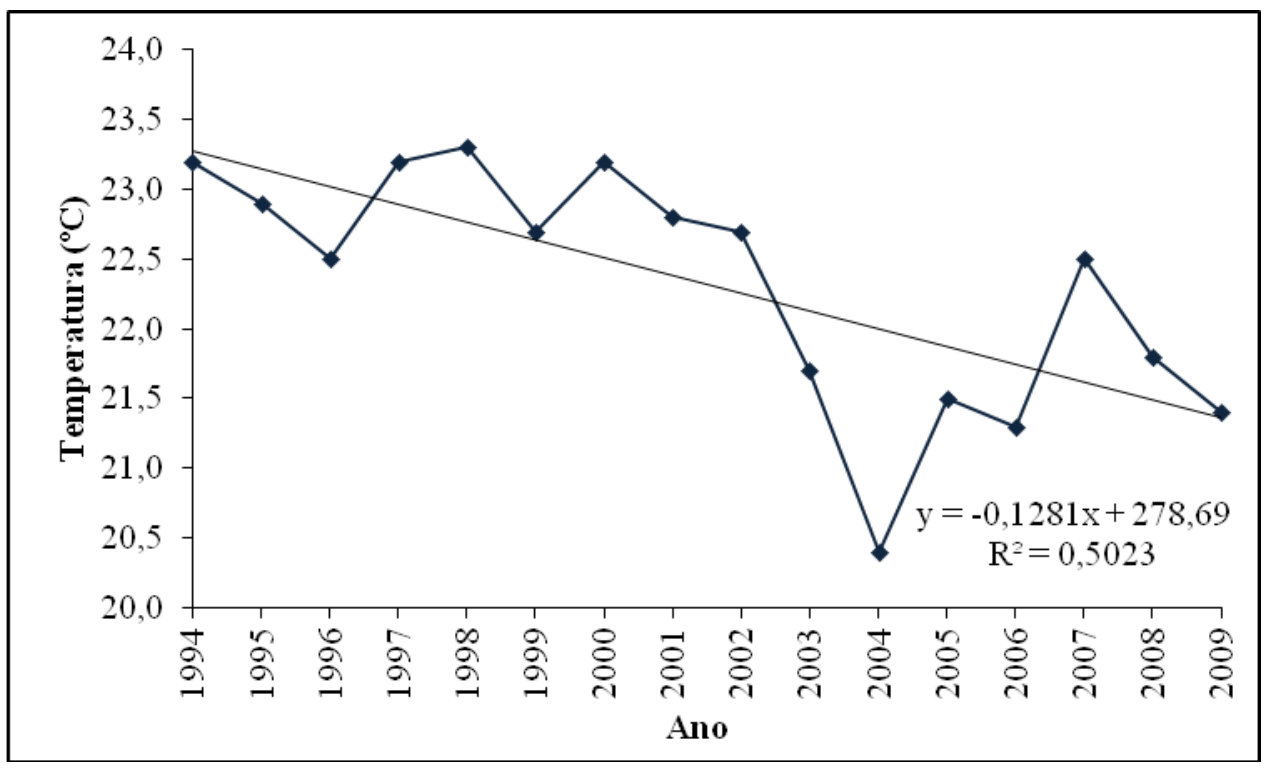

Gráfico 19 - Reta de regressão para a temperatura média anual no município de Pirassununga/SP para os anos de 1994 a 2009.

A análise do Gráfico 20 indica que a reta ajustada para o período apresentou uma pequena tendência de acréscimo, evidenciada pelo coeficiente angular, e uma propensão à elevação da temperatura máxima, numa razão de $0,083^{\circ} \mathrm{C} / \mathrm{ano}$. A maior temperatura máxima ocorreu nos anos de 1997 e $2008\left(39^{\circ} \mathrm{C}\right)$, e a menor, em $2005\left(34,8^{\circ} \mathrm{C}\right)$, resultando em uma amplitude térmica de $4,2^{\circ} \mathrm{C}$, para o período. Então, conforme demonstra o Gráfico 19, a reta de tendência aponta para um aumento de $1,33^{\circ} \mathrm{C}$ na temperatura máxima durante os dezesseis anos de observação da série considerada.

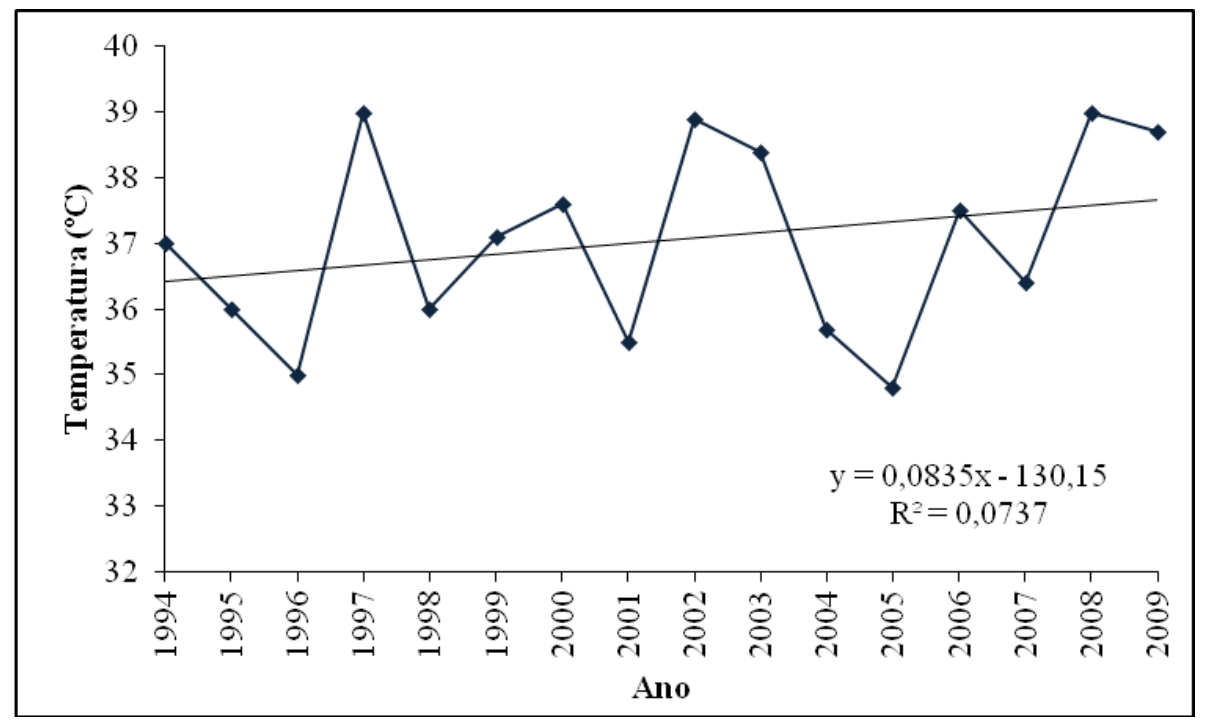

Gráfico 20 - Reta de regressão para a temperatura máxima anual no município de Pirassununga/SP para os anos de 1994 a 2009. 
Em relação à temperatura mínima, o Gráfico 21 evidencia uma tendência de aumento na razão de $0,13^{\circ} \mathrm{C} / \mathrm{ano}$, com $\mathrm{R}^{2}=0,133$, cujo valor de $13,3 \%$, mostra-se muito baixo, indicando que a reta não se ajusta muito bem aos dados da série. A maior temperatura mínima foi de $5^{\circ} \mathrm{C}$ em 1995 e a menor, $-2^{\circ} \mathrm{C}$, em 1994, estabelecendo uma amplitude de $7^{\circ} \mathrm{C}$ para a série, em um intervalo de apenas um ano. A tendência do aumento das temperaturas mínimas sugere a diminuição do número de noites frias para os últimos anos da série. Assim, no Gráfico 20, a reta de tendência aponta para um aumento de $2,1^{\circ} \mathrm{C}$ nos valores das temperaturas mínimas durante os dezesseis anos de observação da série considerada, indicando uma tendência crescente dessa variável.

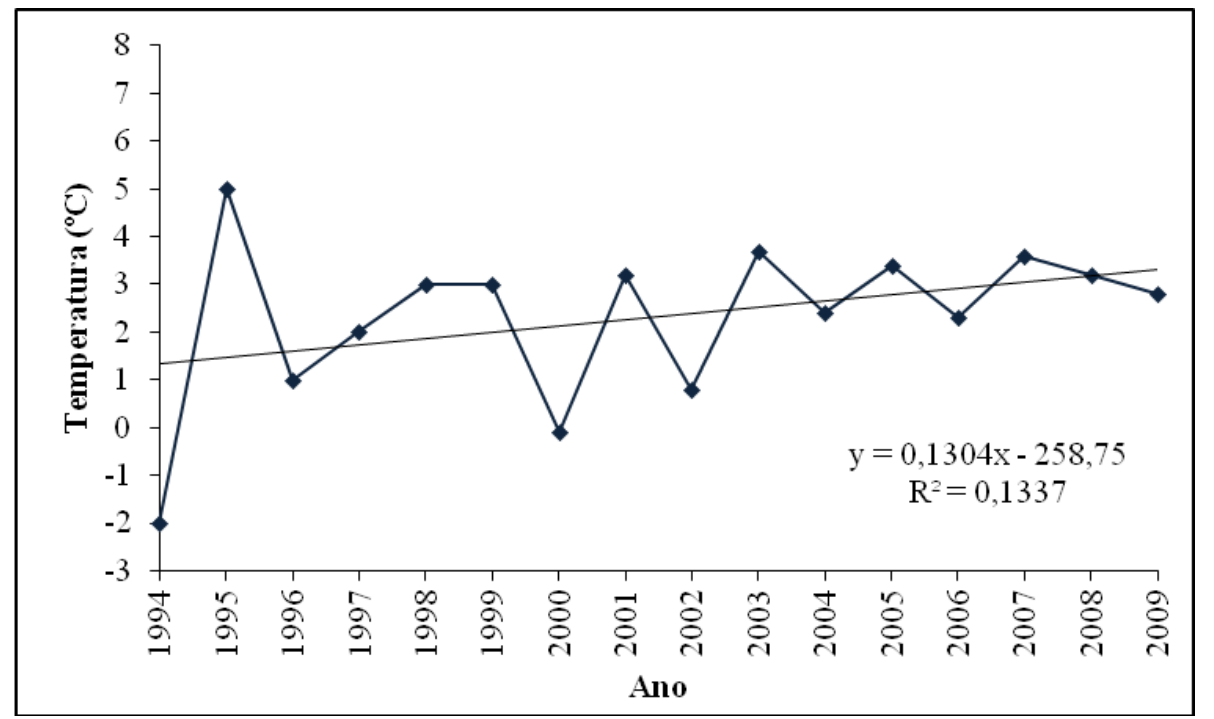

Gráfico 21 - Reta de regressão para a temperatura mínima anual no município de Pirassununga/SP para os anos de 1994 a 2009.

O Gráfico 22 mostra que a temperatura média máxima aponta para uma tendência de decrescimento à taxa de $0,069^{\circ} \mathrm{C}$ ao ano, contabilizando $1,1^{\circ} \mathrm{C}$ ao longo da série de dezesseis anos, para um coeficiente de determinação da reta ajustada aos dados, $\mathrm{R}^{2}=0,141$, muito baixo. Esse valor mostra que a tendência é pouco significativa. A maior TMedMax registrada foi de $34,2^{\circ} \mathrm{C}$, em 1999 e a menor, de $31,1^{\circ} \mathrm{C}$, em 2004 , com amplitude térmica de $3,1^{\circ} \mathrm{C}$. Pode-se então afirmar, pela medida estatística da reta de regressão que essa variável não apresenta tendência significativa. 


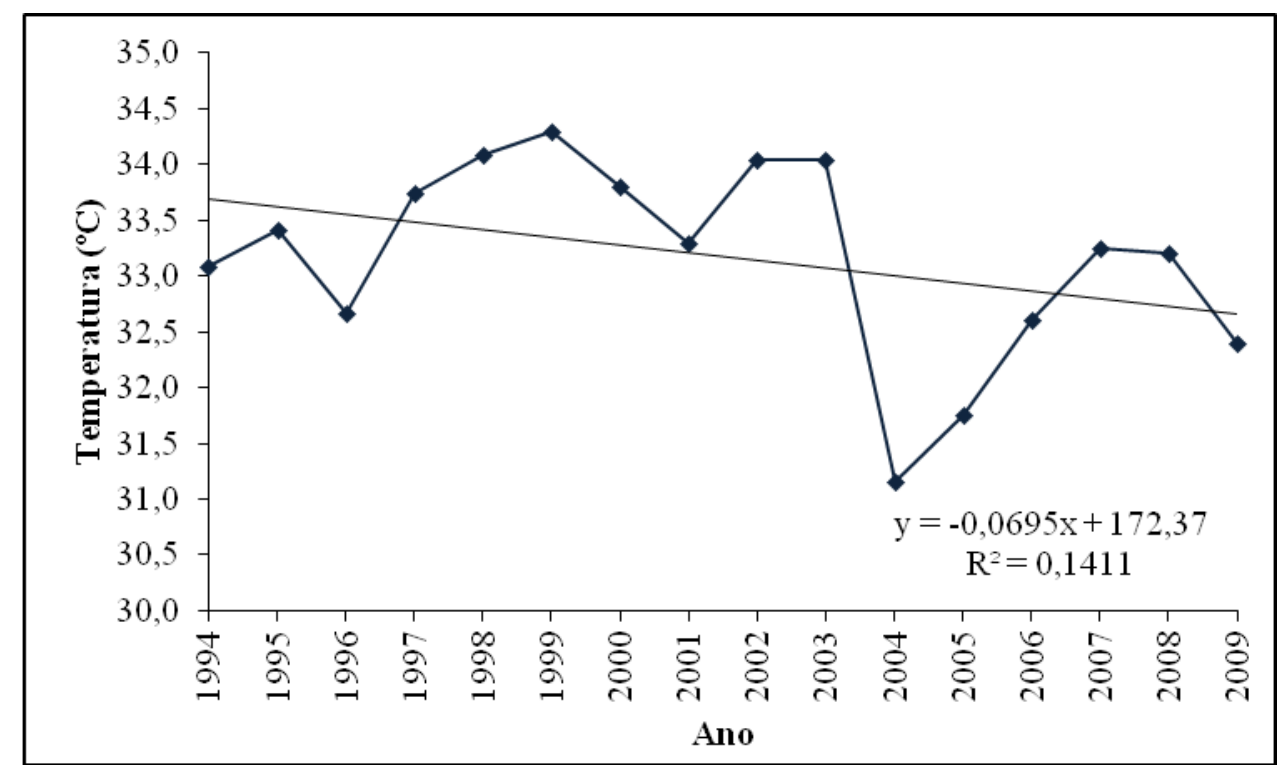

Gráfico 22 - Reta de regressão para a temperatura média máxima anual (TMedMax) no município de Pirassununga/SP para os anos de 1994 a 2009.

A reta de regressão do Gráfico 23 indica um pequeno decréscimo nos valores da temperatura média mínima, à taxa de $0,031^{\circ} \mathrm{C}$ ao ano, totalizando $0,49^{\circ} \mathrm{C}$ para a série toda. Há assim a tendência muito pouco significativa dessa variável, apontando para uma estabilidade da mesma. A maior TMedMin de $11,6^{\circ} \mathrm{C}$ ocorreu em 1996 e a menor, $8,2^{\circ} \mathrm{C}$, em 2004, resultando em uma amplitude térmica de $3,4^{\circ} \mathrm{C}$. Com o valor de $\mathrm{R}^{2}=0,024$ fica evidente que a reta de regressão não foi bem ajustada aos dados, em razão da ausência de uma propensão manifestada pela temperatura. .

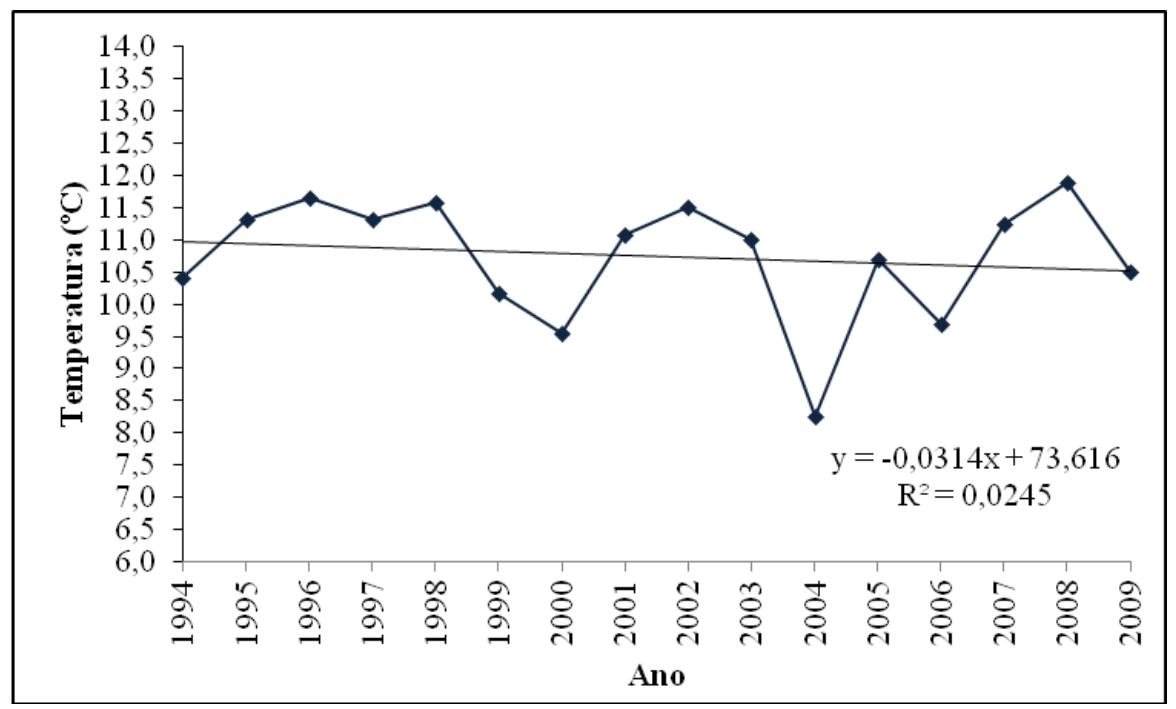

Gráfico 23 - Reta de Regressão para a temperatura média mínima anual (TMedMax) no município de Pirassununga/SP para os anos de 1994 a 2009. 


\subsection{3 - Análise da variabilidade para a pluviosidade}

Para a série temporal estudada (1994 a 2009) registrou-se o total anual médio de 1302,9 mm, sendo 2009, último ano da série, o mais chuvoso (1755,7 mm), e 1994, primeiro ano da série, o menos chuvoso $(810,7 \mathrm{~mm})$, conforme Tabela 14.

Tabela 14 - Valores da pluviosidade total anual no município de Pirassununga/SP para os anos de 1994 a 2009.

\begin{tabular}{cc}
\hline Ano & Pluviosidade (mm) \\
\hline 1994 & 810,7 \\
1995 & 1244,7 \\
1996 & 1676,9 \\
1997 & 1274,8 \\
1998 & 1462,8 \\
1999 & 1220,3 \\
2000 & 1704,8 \\
2001 & 1157,8 \\
2002 & 1131,2 \\
2003 & 1217,1 \\
2004 & 1402,4 \\
2005 & 897,2 \\
2006 & 1291,3 \\
2007 & 1239,6 \\
2008 & 1360,4 \\
2009 & 1755,7 \\
Med & $\mathbf{1 3 0 2 , 9}$ \\
\hline
\end{tabular}

Os meses da estação menos chuvosa em geral apresentam pluviosidades médias mensais abaixo de $80 \mathrm{~mm}$. Já o período compreendido entre o primeiro trimestre (janeiro, fevereiro e março) e o último (outubro, novembro e dezembro), apresenta valores médios de pluviosidade acima de $100 \mathrm{~mm}$. O trimestre menos chuvoso, constituído pelos meses de junho, julho e agosto, apresentou pluviosidade média abaixo dos $40 \mathrm{~mm}$.

A diferença entre a estação chuvosa e a seca tem base nos critérios propostos por Koeppen e Geiger (1936), que consideraram chuvoso o mês que apresenta uma pluviosidade acima de $60 \mathrm{~mm}$.

A Tabela 15 mostra, também, que os meses maio, junho, julho e agosto, registraram valores da pluviosidade mínima iguais a zero ou próximas de zero. As máximas pluviosidades ocorreram nos meses de novembro, dezembro, janeiro, fevereiro e março, com precipitação média de 194,9 mm para esses meses, verificando-se também as máximas pluviosidades para os meses de dezembro $(384,4 \mathrm{~mm})$ janeiro $(383,8 \mathrm{~mm})$ e fevereiro $(418,5 \mathrm{~mm})$. 
A pluviosidade média anual no período foi de $1302,9 \mathrm{~mm}$, com um desvio padrão de $261,1 \mathrm{~mm}$ e coeficiente de variação de 20\%, conforme a Tabela 15.

Tabela 15 - Valores de média, desvio padrão (DP) e coeficiente de variação (CV) da pluviosidade média anual e mensal, no município de Pirassununga/SP para os anos de 1994 a 2009.

\begin{tabular}{cccccc}
\hline Anual/mensal & $\begin{array}{c}\text { Média } \\
(\mathbf{m m})\end{array}$ & $\begin{array}{c}\text { DP } \\
(\mathbf{m m})\end{array}$ & $\begin{array}{c}\text { CV } \\
(\mathbf{\%}) .\end{array}$ & $\begin{array}{c}\text { Max } \\
(\mathbf{m m})\end{array}$ & $\begin{array}{c}\text { Min } \\
(\mathbf{m m})\end{array}$ \\
\hline jan & 247,6 & 58,3 & 23 & 383,8 & 148,2 \\
fev & 233,5 & 108,1 & 46 & 418,5 & 75,1 \\
mar & 136,1 & 68,8 & 50 & 295,6 & 54,4 \\
abr & 53,2 & 43,1 & 81 & 181,6 & 1,1 \\
mai & 47,5 & 33,3 & 70 & 113,5 & 3,0 \\
jun & 13,9 & 36,3 & 261 & 153,5 & 0 \\
jul & 32,7 & 33,9 & 103 & 126,8 & 0 \\
ago & 37,5 & 37,9 & 101 & 123,5 & 0 \\
set & 51,9 & 48,5 & 9,0 & 166,8 & 0 \\
out & 94,0 & 58,7 & 62 & 240,1 & 46,3 \\
nov & 132,9 & 64,8 & 48 & 237,4 & 47,7 \\
dez & 224,6 & 82,5 & 36 & 384,4 & 91,6 \\
anual & $\mathbf{1 3 0 2 , 9}$ & $\mathbf{2 6 1 , 1}$ & $\mathbf{2 0}$ & $\mathbf{1 7 5 5 , 7}$ & $\mathbf{8 1 0 , 7}$ \\
\hline
\end{tabular}

A grande variabilidade da pluviosidade no período pode ser verificada pela observação dos seus valores que oscilaram, principalmente, entre $1100 \mathrm{~mm}$ e $1700 \mathrm{~mm}$, com destaque para os biênios 1994 - 1995 e 2005 - 2006, quando a pluviosidade aumentou de 810,7 mm para $1244,7 \mathrm{~mm}$, e de $897,2 \mathrm{~mm}$ para $1291,3 \mathrm{~mm}$, de um ano para o outro.

Para os dados referentes aos dezesseis anos de observação, apenas cinco registraram pluviosidade acima da média e os onze restantes, abaixo da média.

O Gráfico 24 mostra a distribuição temporal da pluviosidade total anual no município de Pirassununga/SP, no período de 1994 a 2009. O gráfico permite constatar que a pluviosidade anual apresentou-se bem distribuída ao longo da série chamando a atenção para os máximos valores registrados nos anos de 2000 e 2009. A pluviosidade anual média nesse período é de 1302,9 mm, valor próximo da normal climatológica de $1352 \mathrm{~mm}$, determinada pelo INMET. 


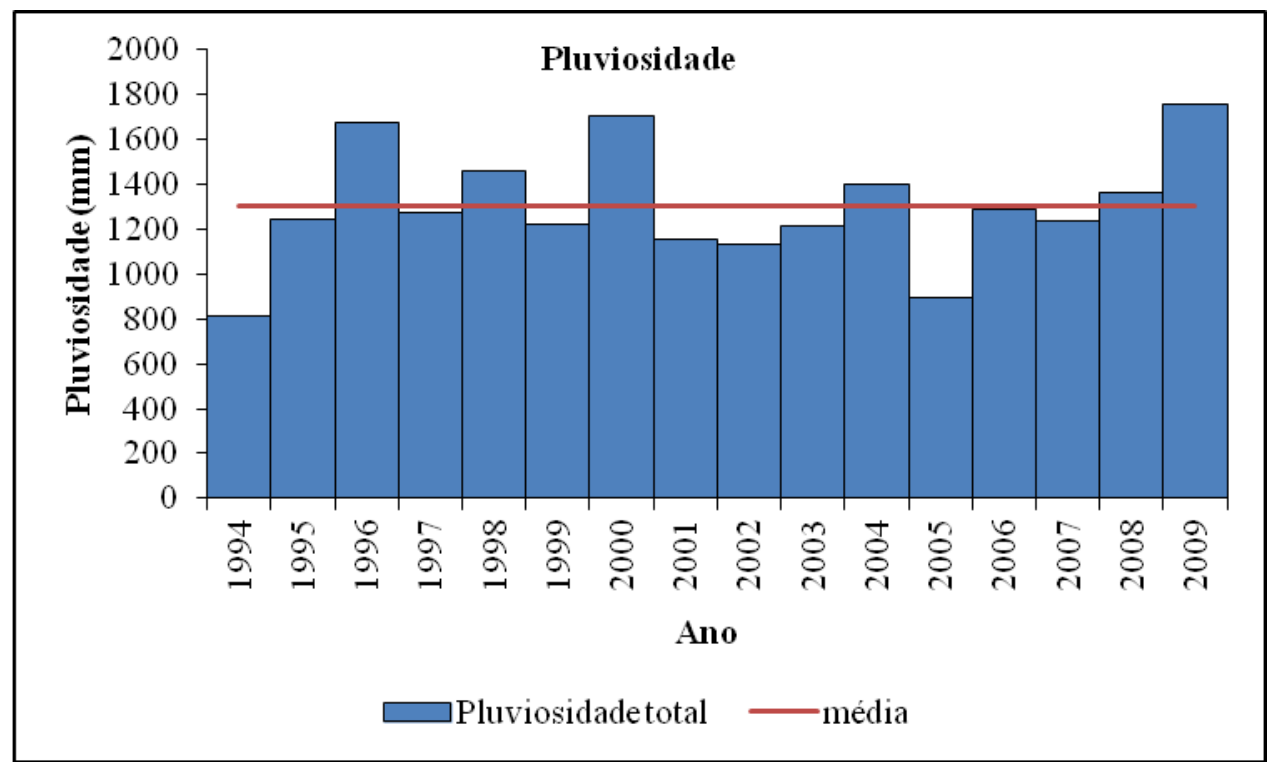

Gráfico 24 - Pluviosidade total anual de Pirassununga/SP de 1994 a 2009.

A curva do Gráfico 25 tem o objetivo de mostrar também, a variabilidade da chuva em intervalos menores. Portanto, o polinômio de quinto grau ajustado à série de dados anuais aponta para a grande variabilidade desse fenômeno, que, ao longo da série apresentou valores oscilando entre 1100 e 1600 mm, com exceção para os anos de 2009 e 1994 que apresentaram valores extremos. Ao efetuar a análise por períodos mais curtos ao longo da série, observa-se que a curva indica variabilidades crescentes entre 1994 a 1996, decrescendo acentuadamente entre os anos de 1996 a 1999. Entre 2001 e 2004 volta a ter um comportamento levemente crescente e após um valor decrescente em 2005, sua oscilação torna-se moderada até o final da série, evidenciando com mais clareza a variabilidade do regime de chuvas para a localidade. 


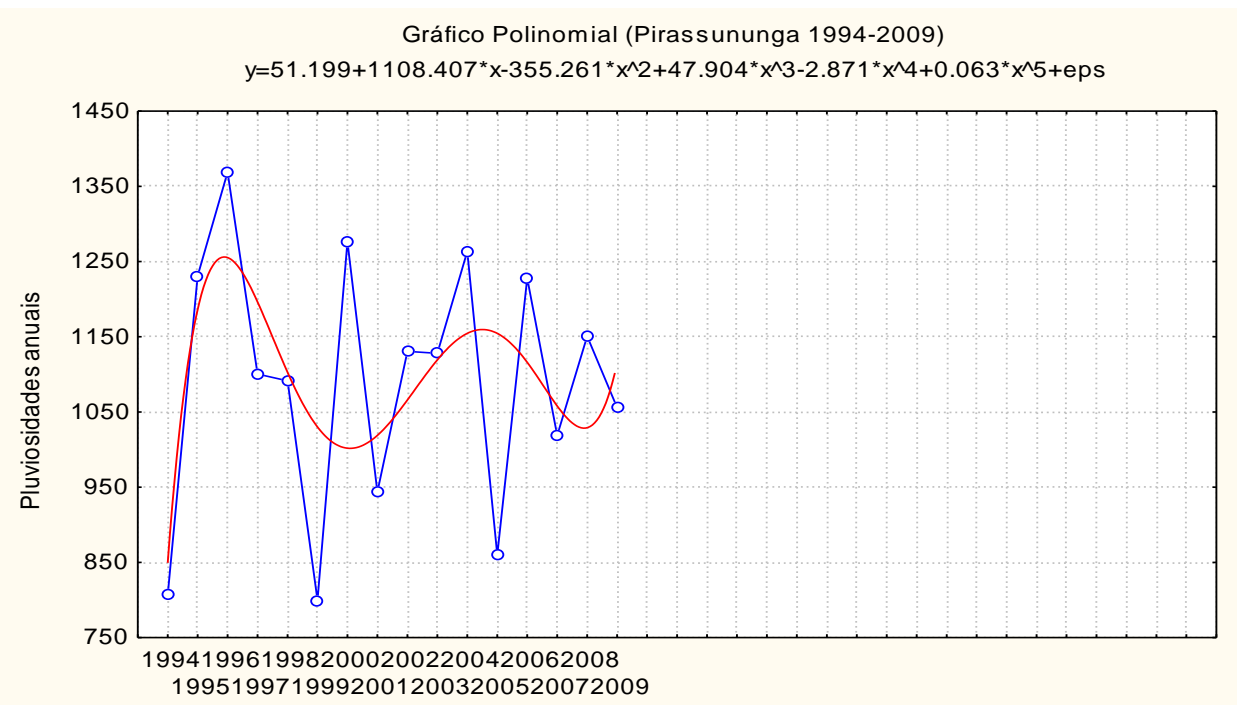

Gráfico 25 - Pluviosidade total anual de Pirassununga/SP de 1994 a 2009, curva de regressão polinomial de grau 5.

\subsection{4 - Análise da tendência para a pluviosidade: reta de regressão}

O Gráfico 26 mostra a reta de tendência para a pluviosidade. A inclinação da reta de regressão permite constatar que houve acréscimo de 152,4 mm de chuva ao longo da série, da ordem de 9,527 mm/ano, o que pode ser considerado um ligeiro aumento nos valores da pluviosidade no período analisado. A análise dos dados indica, então, uma tendência de elevação nos valores da precipitação na localidade. O valor do coeficiente de determinação $\left(\mathrm{R}^{2}=0,030\right)$ mostra, também, que nenhuma variação da pluviosidade está associada ao tempo. Os dados obtidos permitem reconhecer que não houve mudança no tipo de clima e que a pequena tendência à elevação observada no comportamento da pluviosidade, mesmo considerando alguns extremos, está relacionada com as variações na oscilação e intensidade das massas de ar. 


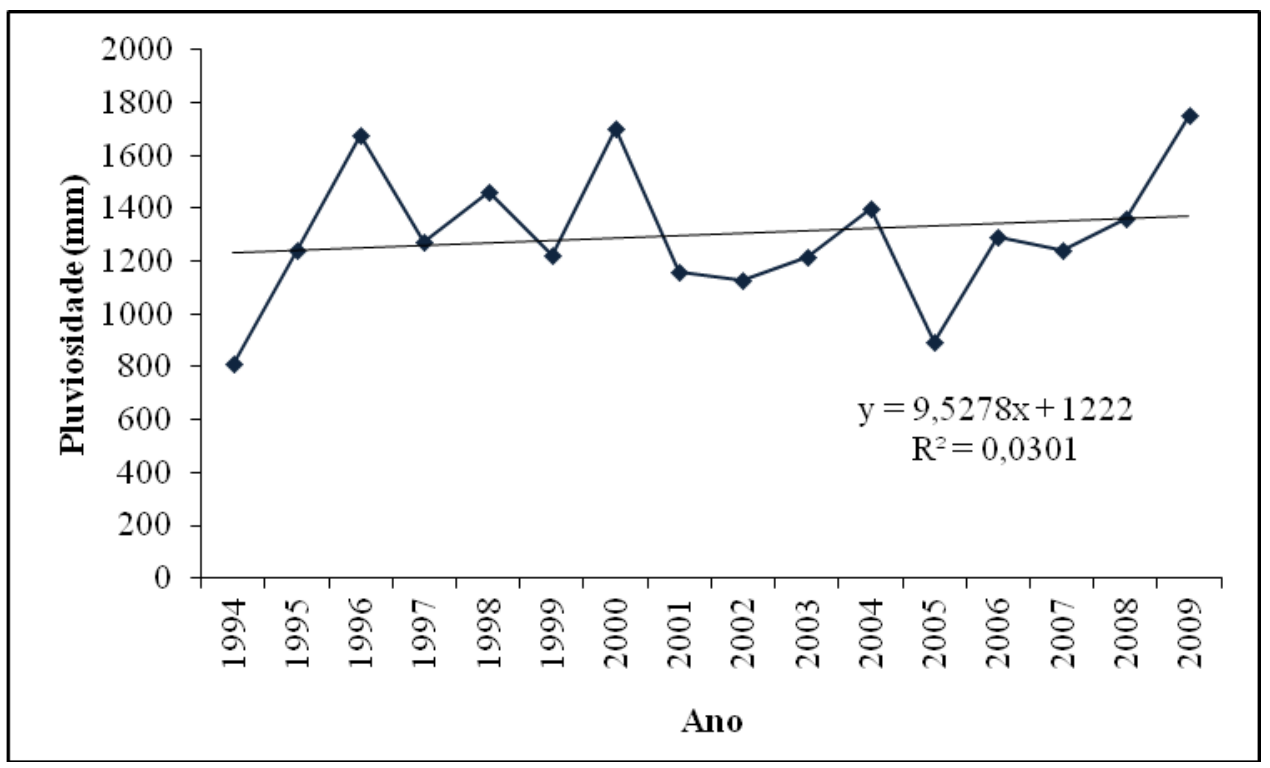

Gráfico 26 - Tendência da pluviosidade total anual no município de Pirassununga/SP no período de 1994 a 2009 - reta de regressão.

\subsection{5 - Análise da tendência para a temperatura e pluviosidade - Teste de Mann-Kendall e Curvatura de Sen.}

\subsubsection{1 - Medidas estatísticas das temperaturas máximas, médias máximas, mínimas, médias mínimas, médias e pluviosidades em Pirassununga no período de 1994-2009.}

Utilizando os aplicativos estatísticos Statistica e BioEstat foram obtidos resultados apresentados abaixo para a cidade de Pirassununga no período de 1994-2009.

A Tabela 16 mostra proximidade entre as medidas estatísticas Mínimo, Máximo e M.A. para as temperaturas, o mesmo não ocorrendo com a pluviosidade. Para cada coluna, o comportamento das medidas de variabilidade: desvio padrão (DP) e coeficiente de variação $\mathrm{CV}(\%)$ são baixos para as séries, indicando pouca variabilidade entre os dados. Em relação à assimetria, todas as séries são classificadas como assimétricas. As séries das colunas 2, 3, 4 e 5 são assimétricas à esquerda, pois apresentam os coeficientes do momento de assimetria negativos, enquanto as séries para a coluna 1 é classificada como assimétrica à direita ou positiva. Em relação à curtose, todas as distribuições são classificadas como platicúrticas, pois as medidas das colunas são menores que 3 . 
Tabela 16 - Medidas estatísticas de temperatura máxima, temperatura média máxima, temperatura mínima, temperatura média mínima e pluviosidade.

\begin{tabular}{|l|c|c|c|c|c|}
\hline \multirow{2}{*}{ Estatística } & \multicolumn{5}{|c|}{ Variáveis Meteorológicas } \\
\cline { 2 - 6 } & $\begin{array}{c}\text { temperatura } \\
\text { máxima } \\
\left({ }^{\circ} \mathrm{C}\right)\end{array}$ & $\begin{array}{c}\text { temperatura } \\
\text { média máxima } \\
\left({ }^{\circ} \mathrm{C}\right)\end{array}$ & $\begin{array}{c}\text { temperatura } \\
\text { mínima } \\
\left({ }^{\circ} \mathrm{C}\right)\end{array}$ & $\begin{array}{c}\text { temperatura } \\
\text { média mínima } \\
\left({ }^{\circ} \mathrm{C}\right)\end{array}$ & $\begin{array}{c}\text { pluviosidade } \\
(\mathrm{mm})\end{array}$ \\
\hline Mínimo & 34,80 & 31,16 & $-2,00$ & 8,27 & 799,60 \\
Máximo & 39,00 & 34,29 & 5,00 & 11,90 & 1368,90 \\
M. A. & 37,03 & 33,17 & 2,33 & 10,74 & 1090,81 \\
DP & 1,4651 & 0,8814 & 1,6985 & 0,9563 & 170,0225 \\
CV(\%) & 3,96 & 2,66 & 2,86 & 8,90 & 15,59 \\
Assim. & 0,0194 & $-0,8922$ & $-1,1625$ & $-1,2530$ & $-0,3851$ \\
Curtose & $-1,4058$ & $-1,0166$ & 1,7408 & 1,5982 & $-0,6254$ \\
\hline
\end{tabular}

Onde: M. A. = Média Aritmética; DP = Desvio Padrão; CV = Coeficiente de Variação; Assim. $=$ coeficiente de assimetria Curtose $=$ Coeficiente de Curtose .

\subsubsection{2 - Análises das tendências e das estimativas}

A seguir apresentam-se resultados das análises das variáveis meteorológicas a partir dos testes estatísticos de Mann-Kendall (MK) e Curvatura de Sen (CS), considerando-se o nível de confiança de $95 \%$ ou $\alpha=5 \%$.

Tabela 17 - Análise Estatística das Variáveis Meteorológicas $(\alpha=5 \%)$ para Pirassununga/SP - 1994 a 2009.

\begin{tabular}{|l|c|c|c|c|c|c|}
\hline \multirow{3}{*}{ Estatística } & \multicolumn{7}{|c|}{ Variáveis Meteorológicas } \\
\cline { 2 - 7 } & $\begin{array}{c}\text { Temperatura } \\
\text { Máxima } \\
\left({ }^{\circ} \mathrm{C}\right)\end{array}$ & $\begin{array}{c}\text { Temperatura } \\
\text { Média Máxima } \\
\left({ }^{\circ} \mathrm{C}\right)\end{array}$ & $\begin{array}{c}\text { Temperatura } \\
\text { Mínima } \\
\left({ }^{\circ} \mathrm{C}\right)\end{array}$ & $\begin{array}{c}\text { Temperatura } \\
\text { Média Mínima } \\
\left({ }^{\circ} \mathrm{C}\right)\end{array}$ & $\begin{array}{c}\text { Temperatura } \\
\text { Média } \\
\left({ }^{\circ} \mathrm{C}\right)\end{array}$ & $\begin{array}{c}\text { Pluviosidade } \\
(\mathrm{mm})\end{array}$ \\
\hline Escore Z & 0,8572 & 1,1718 & 1,2181 & 0,6310 & $-1,9966$ & 0,1351 \\
MannKendall & 0,1667 & 0,2250 & 0,2333 & 0,1250 & $-0,3750$ & 0,0333 \\
Curvat.Sen & 0,0938 & 0,0500 & 0,0900 & 0,0386 & $-0,084$ & 2,0600 \\
Prob. (p) & 0,3914 & 0,2413 & 0,2232 & 0,5281 & 0,0459 & 0,8926 \\
\hline
\end{tabular}

A Tabela 17 permite verificar que os resultados das colunas das temperaturas máximas, médias máximas, mínimas e médias mínimas indicam tendências positivas com 0,1667, 0,2250, 0,2333 e 0,1250 (Mann-Kendall), crescente ou positiva, pois Z>0 próximo de um, sendo insignificante, pois $p>\alpha$ e que as tendências dessas variáveis (anuais) é de aumentar aproximadamente $0,0938^{\circ} \mathrm{C}, \quad 0,0500^{\circ} \mathrm{C}, \quad 0,0900^{\circ} \mathrm{C}$ e $0,03868^{\circ} \mathrm{C}$ por ano, respectivamente. Para a pluviosidade total anual, pode-se constatar que não há tendência 
significativa, pois, embora $Z>0$, seu valor fica próximo de zero, com $p>\alpha$, a magnitude da tendência também apresenta valor insignificante (-2,06 mm/ano). Essa tendência de acréscimo no valor da pluviosidade ocorreu também quando se utilizou a reta de regressão (Gráfico 26), onde a taxa de aumento foi da ordem de 9,527 mm/ano, dada pelo coeficiente angular, mostrando coerência quanto à tendência havendo, com uma diferença na magnitude da grandeza.

Em relação à coluna das temperaturas médias os resultados mostram uma tendência negativa, com $-0,3750(\mathrm{MK})$, decrescente, pois $\mathrm{Z}<0$ e significante, pois $p<\alpha$, com magnitude de tendência de $-0,084^{\circ} \mathrm{C} / \mathrm{ano}$, contabilizando $-1,35^{\circ} \mathrm{C}$ ao longo dos dezesseis anos da série. Comparativamente, para essa mesma variável pode-se observar no Gráfico 19, que a equação reta de regressão é dada por y $=-0,128 x+278,6$, onde o coeficiente angular igual a 0,128, mostrando que pode ocorrer um decréscimo de $0,128^{\circ} \mathrm{C} / \mathrm{ano}$, resultando em aproximadamente $-2^{\circ} \mathrm{C}$ no decorrer da série toda. Verifica-se então certa coerência em relação ao declínio da tendência e sua respectiva magnitude, quando estimada pelos dois métodos.

5.3 - Análise dos dados de temperatura e pluviosidade da série temporal de 1994 a 2009 , para Rio Claro/SP.

\subsection{1 - Análise da variabilidade da temperatura}

\subsubsection{1 - Temperatura média}

De acordo com a Tabela 18 a análise do comportamento anual da temperatura durante a série temporal considerada (1994-2009) mostra que a temperatura média anual do período é de $22,9^{\circ} \mathrm{C}$. A temperatura média mais elevada foi de $23,7^{\circ} \mathrm{C}$, registrada em 2002 ; e a média mais baixa, $22,3^{\circ} \mathrm{C}$, ocorreu em 1996, com uma pequena amplitude térmica, de $1,4^{\circ} \mathrm{C}$, indicando inexistência de variabilidade. 
Tabela 18 - Valores da temperatura média anual no município de Rio Claro/SP para a série temporal de 1994 a 2009.

\begin{tabular}{cc}
\hline Ano & Tméd $\left({ }^{\mathbf{C}} \mathbf{)}\right.$ \\
\hline 1994 & 22,8 \\
1995 & 22,7 \\
1996 & 22,3 \\
1997 & 22,7 \\
1998 & 22,7 \\
1999 & 22,5 \\
2000 & 22,8 \\
2001 & 23,3 \\
2002 & 23,7 \\
2003 & 23,2 \\
2004 & 22,4 \\
2005 & 23,2 \\
2006 & 22,9 \\
2007 & 23,5 \\
2008 & 22,8 \\
2009 & 23,1 \\
\hline
\end{tabular}

Quanto ao comportamento mensal dessa variável, a Tabela 19 mostra que o primeiro e o último trimestres do ano representam os períodos com temperaturas mais elevadas, sendo fevereiro o mês mais quente do ano, com média mensal de $25,3^{\circ} \mathrm{C}$, desvio padrão de $0,84^{\circ} \mathrm{C}$, coeficiente de variação de $3,3 \%$, temperatura média máxima igual a $27,2^{\circ} \mathrm{C}$ e média mínima de $23,8^{\circ} \mathrm{C}$ (maior temperatura média mínima da série). Já os meses de maio, junho, julho e agosto representam o período do ano com temperaturas menos elevadas, sendo junho o mais frio do ano, com temperatura média de $18,9^{\circ} \mathrm{C}$, desvio padrão de $1,2^{\circ} \mathrm{C}$, coeficiente de variação de $6,2 \%$ e temperatura média máxima de $20,9^{\circ} \mathrm{C}$ e média mínima de $16,9^{\circ} \mathrm{C}$. Junho é mês com maior coeficiente de variação é junho $(\mathrm{CV}=6,2 \%)$, mostrando maior variabilidade da temperatura média do ar para a série; dezembro é o mês com menor coeficiente de variação $(\mathrm{CV}=1,8 \%)$, mostrando pouca variabilidade, ou seja, a temperatura manteve-se próxima de um valor constante para todos os meses de dezembro da série. 
Tabela 19 - Valores da temperatura média, desvio padrão (DP) e coeficiente de variação (CV) da temperatura média anual e mensal no município de Rio Claro/SP para os anos de 1994 a 2009.

\begin{tabular}{cccccc}
\hline Anual/mensal & $\begin{array}{c}\text { Média } \\
\left.\mathbf{(}^{\mathbf{C}} \mathbf{C}\right)\end{array}$ & $\begin{array}{c}\text { DP } \\
\left(\mathbf{(}^{\mathbf{0}} \mathbf{C}\right)\end{array}$ & $\begin{array}{c}\mathbf{C V} \\
(\mathbf{\%}) \mathbf{~}\end{array}$ & $\begin{array}{c}\text { MaxMed } \\
\left({ }^{\mathbf{0}} \mathbf{C}\right)\end{array}$ & $\begin{array}{c}\text { MinMed } \\
\left({ }^{\mathbf{0}} \mathbf{C}\right)\end{array}$ \\
\hline jan & 25,0 & 0,7 & 2,7 & 26,4 & 24,2 \\
fev & 25,3 & 0,8 & 3,3 & 27,2 & 23,8 \\
mar & 25,0 & 0,8 & 3,4 & 26,4 & 23,8 \\
abr & 23,3 & 0,9 & 3,7 & 25,6 & 22,3 \\
mai & 20,0 & 0,8 & 4,3 & 21,7 & 18,9 \\
jun & 18,9 & 1,2 & 6,2 & 20,9 & 16,9 \\
jul & 19,0 & 0,7 & 3,8 & 20,0 & 17,4 \\
ago & 21,3 & 0,9 & 4,5 & 22,7 & 19,5 \\
set & 22,9 & 1,2 & 5,1 & 25,4 & 21,3 \\
out & 24,5 & 1,5 & 6 & 27,8 & 22,4 \\
nov & 24,8 & 0,7 & 2,8 & 26,5 & 23,7 \\
dez & 25,2 & 0,5 & 1,8 & 25,9 & 24,5 \\
Anual & $\mathbf{2 2 , 9}$ & $\mathbf{0 , 4}$ & $\mathbf{1 , 7}$ & $\mathbf{2 3 , 7}$ & $\mathbf{2 2 , 3}$ \\
\hline
\end{tabular}

A análise da distribuição dessa variável climática ao longo da série (Gráfico 27) mostra que, dos dezesseis anos, apenas seis apresentaram temperatura média anual acima da média da série, sendo que os últimos sete anos apontam para uma diminuição dos valores médios, verificando-se o desvio padrão de $0,4^{\circ} \mathrm{C}$ e o coeficiente de variação de $1,7 \%$, conforme a Tabela 19. O Gráfico 27 mostra, também, que a temperatura média apresentou pequena variabilidade. Nos últimos sete anos, com exceção de 2004, os valores da temperatura registrados foram bem próximos do valor médio.Pode-se constatar, ainda, que os últimos cinco anos da série registram temperaturas oscilando em torno da média, com diferenças inferiores a $1^{\circ} \mathrm{C}$, com baixíssima variabilidade da temperatura média. 


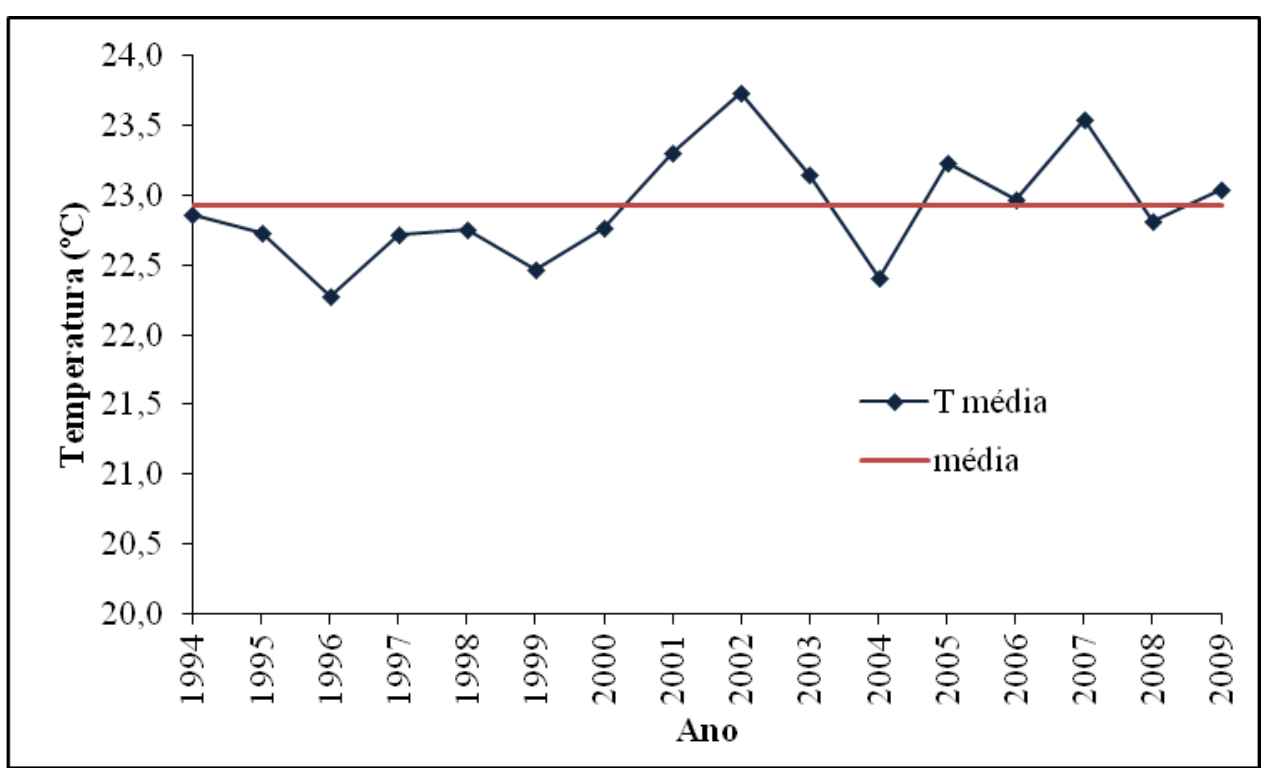

Gráfico 27 - Temperatura média anual no município de Rio Claro/SP para os anos de 1994 a 2009.

\subsubsection{2 - Temperatura máxima}

De acordo com a Tabela 20 verifica-se que a média das temperaturas máximas para o período, é de $36,4^{\circ} \mathrm{C}$. A maior temperatura máxima, $38,4^{\circ} \mathrm{C}$, ocorreu em 2002 , e a menor máxima, $34,4^{\circ} \mathrm{C}$, em 1996. A amplitude térmica desse período resultou em $4^{\circ} \mathrm{C}$, indicando a ocorrência de pequena variabilidade anual das temperaturas máximas, com valores oscilando em torno da média.

Em relação ao comportamento mensal da temperatura máxima, na Tabela 21, os valores mostram que outubro é o mês mais quente da série, com temperatura média máxima de $35,3^{\circ} \mathrm{C}$, máxima de $38,4^{\circ} \mathrm{C}$ e mínima de $32,4^{\circ} \mathrm{C}$, com um desvio padrão de $1,8^{\circ} \mathrm{C}$ e coeficiente de variação de 5\%. O mês de junho configurou-se como o mais frio, com temperatura média máxima de $28,2^{\circ} \mathrm{C}$, mínima máxima de $27,4^{\circ} \mathrm{C}$, desvio padrão de $9,9^{\circ} \mathrm{C}$ e coeficiente de variação de $3 \%$. A amplitude térmica de $7,3^{\circ} \mathrm{C}\left(35,5^{\circ} \mathrm{C}-28,2^{\circ} \mathrm{C}\right)$ aponta para uma acentuada variabilidade climática entre os meses do período considerado. 
Tabela 20 - Valores da temperatura máxima anual no município de Rio Claro/SP para a série temporal de 1994 a 2009.

\begin{tabular}{cc}
\hline Ano & Tmáx $\left({ }^{\mathbf{O}} \mathbf{C}\right)$ \\
\hline 1994 & 37,2 \\
1995 & 35,8 \\
1996 & 34,4 \\
1997 & 37,2 \\
1998 & 35,8 \\
1999 & 36,0 \\
2000 & 36,4 \\
2001 & 35,2 \\
2002 & 38,4 \\
2003 & 37,0 \\
2004 & 37,0 \\
2005 & 36,8 \\
2006 & 36,8 \\
2007 & 37,6 \\
2008 & 37,0 \\
2009 & 34,8 \\
Med & $\mathbf{3 6 , 4}$ \\
\hline
\end{tabular}

Tabela 21 - Valores da temperatura máxima, desvio padrão (DP) e coeficiente de variação (CV) da temperatura média anual e mensal no município de Rio Claro/SP para os anos de 1994 a 2009.

\begin{tabular}{cccccc}
\hline Anual/mensal & $\begin{array}{c}\text { Med Max } \\
\left({ }^{\mathbf{0}} \mathbf{C}\right)\end{array}$ & $\begin{array}{c}\text { DP } \\
\left({ }^{\mathbf{0}} \mathbf{C}\right)\end{array}$ & $\begin{array}{c}\mathbf{C V} \\
(\mathbf{\%})\end{array}$ & $\begin{array}{c}\text { MaxMax } \\
\left({ }^{\mathbf{0}} \mathbf{C}\right)\end{array}$ & $\begin{array}{c}\text { MinMax } \\
\left({ }^{\mathbf{0}} \mathbf{C}\right)\end{array}$ \\
\hline jan & 34,1 & 1,1 & 3 & 36,6 & 32,4 \\
fev & 33,9 & 1,0 & 2 & 35,6 & 32,2 \\
mar & 33,5 & 0,8 & 2 & 35,0 & 32,0 \\
abr & 32,1 & 0,9 & 2 & 33,5 & 30,6 \\
mai & 30,6 & 0,9 & 2 & 30,6 & 29,2 \\
jun & 28,2 & 9,9 & 3 & 29,2 & 27,4 \\
jul & 30,7 & 1,1 & 3 & 33,0 & 29,0 \\
ago & 33,2 & 1,3 & 4 & 35,5 & 30,4 \\
set & 35,3 & 1,5 & 4 & 37,2 & 33,2 \\
out & 35,5 & 1,8 & 5 & 38,4 & 32,4 \\
nov & 34,7 & 1,0 & 2 & 36,8 & 33,0 \\
dez & 34,1 & 1,2 & 3 & 36,0 & 32,6 \\
anual & $\mathbf{3 3 , 1}$ & $\mathbf{0 , 5}$ & $\mathbf{1}$ & $\mathbf{3 3 , 8}$ & $\mathbf{3 2 , 3}$ \\
\hline
\end{tabular}

A distribuição da temperatura máxima ao longo da série, conforme o Gráfico 28, mostra que foram registrados seis valores abaixo da média $\left(36,4^{\circ} \mathrm{C}\right)$, nove acima da média e 
apenas um valor coincidindo com média. Excetuando-se os dois valores um pouco mais extremos $\left(38,4^{\circ} \mathrm{C}\right.$ e $\left.34,4^{\circ} \mathrm{C}\right)$, a distribuição praticamente oscilou em torno do valor médio, com desvio padrão de $0,5^{\circ} \mathrm{C}$ e coeficiente de variação de $1 \%$, indicando baixa dispersão, inexistência de variabilidade, em concordância com o comportamento apresentado na temperatura média.

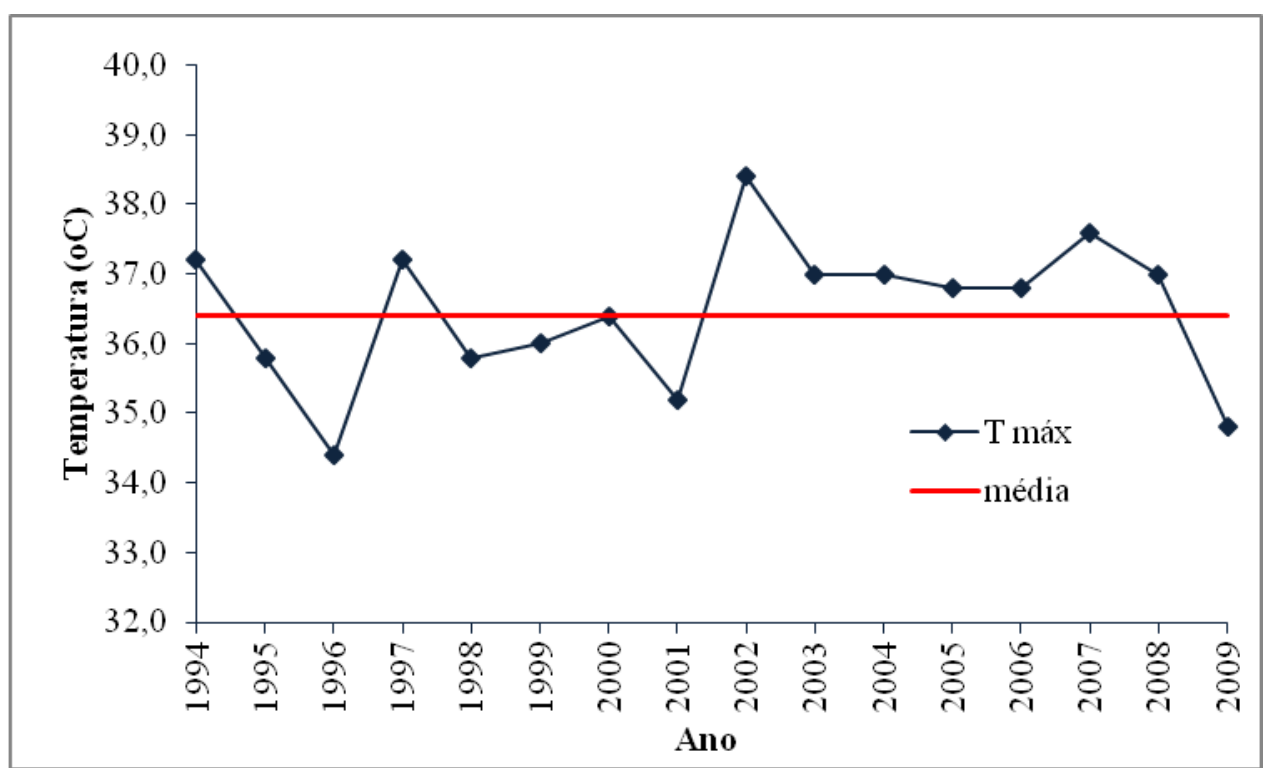

Gráfico 28 - Temperatura máxima anual no município de Rio Claro/SP para os anos de 1994 a 2009.

\subsubsection{3 - Temperatura mínima}

Os dados da Tabela 22 permitem constatar que a média das temperaturas mínimas é de $2,6^{\circ} \mathrm{C}$, a menor mínima é de $-1,8^{\circ} \mathrm{C}$, registrada em 1994 , e a maior, $5,6^{\circ} \mathrm{C}$, em 2005 , determinando uma amplitude térmica de $7,4^{\circ} \mathrm{C}$, indicativo de uma variabilidade bem mais acentuada para a temperatura mínima anual em relação ao ocorrido com a temperatura média e com a máxima. 
Tabela 22 - Valores da temperatura mínima anual no município de Rio Claro/SP para a série temporal de 1994 a 2009.

\begin{tabular}{cc}
\hline Ano & Tmin $\left({ }^{\mathbf{0}} \mathbf{)}\right.$ \\
\hline 1994 & $-1,8$ \\
1995 & 4,2 \\
1996 & 1,6 \\
1997 & 2,6 \\
1998 & 3,8 \\
1999 & 3,0 \\
2000 & 0,2 \\
2001 & 2,0 \\
2002 & 2,0 \\
2003 & 4,2 \\
2004 & 4,0 \\
2005 & 5,6 \\
2006 & 2,6 \\
2007 & 3,0 \\
2008 & 4,6 \\
2009 & 1,2 \\
Med & $\mathbf{2 , 6}$ \\
\hline
\end{tabular}

A análise dos dados mensais da Tabela 23 mostra que os valores indicam janeiro com o mês mais quente da série, com temperatura média mínima de $16,7^{\circ} \mathrm{C}$, máxima de $19,2^{\circ} \mathrm{C}$ e mínima de $14,2^{\circ} \mathrm{C}$, com desvio padrão de $1,5^{\circ} \mathrm{C}$ e coeficiente de variação de $8 \%$. Os meses de junho e julho, com valores bem próximos, mostraram-se os mais frios, com temperaturas médias mínimas de $4,2^{\circ} \mathrm{C}$, máximas de $11^{\circ} \mathrm{C}$ e $7,4^{\circ} \mathrm{C}$ e mínimas de $-1,6^{\circ} \mathrm{C}$ e $-1,8^{\circ} \mathrm{C}$, respectivamente. Os desvios padrão tiveram valores iguais a $2,9^{\circ} \mathrm{C}$ e $2,5^{\circ} \mathrm{C}$, e os coeficientes de variação, valores de $69 \%$ e $58 \%$, respectivamente, indicando uma grande variabilidade térmica para esses dois meses. A amplitude térmica da temperatura média mínima é igual a $16^{\circ} \mathrm{C}\left[14,2^{\circ} \mathrm{C}-\left(-1,8^{\circ} \mathrm{C}\right)\right]$, indicando a ocorrência de uma grande variabilidade climática dessa variável entre os meses de janeiro e julho para a série estudada. 
Tabela 23 - Valores da temperatura mínima, desvio padrão (DP) e coeficiente de variação (CV) da temperatura média anual e mensal no município de Rio Claro/SP para os anos de 1994 a 2009.

\begin{tabular}{cccccc}
\hline Anual/mensal & $\begin{array}{c}\text { Med Min } \\
\left({ }^{\mathbf{0}} \mathbf{C}\right)\end{array}$ & $\begin{array}{c}\text { DP } \\
\left({ }^{\mathbf{0}} \mathbf{C}\right)\end{array}$ & $\begin{array}{c}\mathbf{C V} \\
(\mathbf{\%})\end{array}$ & $\begin{array}{c}\text { MaxMin } \\
\left({ }^{\mathbf{0}} \mathbf{C}\right)\end{array}$ & $\begin{array}{c}\text { MinMin } \\
\left({ }^{\mathbf{}} \mathbf{C}\right)\end{array}$ \\
\hline jan & 16,7 & 1,5 & 8 & 19,2 & 14,2 \\
fev & 16,2 & 1,3 & 7 & 18,2 & 14,2 \\
mar & 15,1 & 1,1 & 7 & 16,6 & 13,0 \\
abr & 10,8 & 2,5 & 23 & 14,6 & 4,4 \\
mai & 6,2 & 1,9 & 31 & 9,6 & 3,0 \\
jun & 4,2 & 2,9 & 69 & 11,0 & $-1,6$ \\
jul & 4,2 & 2,5 & 58 & 7,4 & $-1,8$ \\
ago & 6,0 & 2,7 & 45 & 11,4 & 0,6 \\
set & 8,3 & 2,6 & 31 & 11,8 & 2,0 \\
out & 12,1 & 1,8 & 15 & 15,4 & 8,4 \\
nov & 13,1 & 1,9 & 14 & 16,8 & 10,0 \\
dez & 15,1 & 1,6 & 11 & 17,2 & 11,0 \\
anual & $\mathbf{1 0 , 7}$ & $\mathbf{0 , 6}$ & $\mathbf{6}$ & $\mathbf{1 1 , 8}$ & $\mathbf{9 , 7}$ \\
\hline
\end{tabular}

A análise do Gráfico 29 mostra que, com exceção dos dois primeiros anos da série, em que a temperatura mínima variou de $-1,8^{\circ} \mathrm{C}$ até $5,6^{\circ} \mathrm{C}$, os dez anos seguintes não apresentaram variabilidade significativa, a não ser 2005, com o maior valor registrado, quando a oscilação foi um pouco mais acentuada. Os últimos quatro anos da série apresentaram valores bem próximos da média, com variabilidade mais baixa.

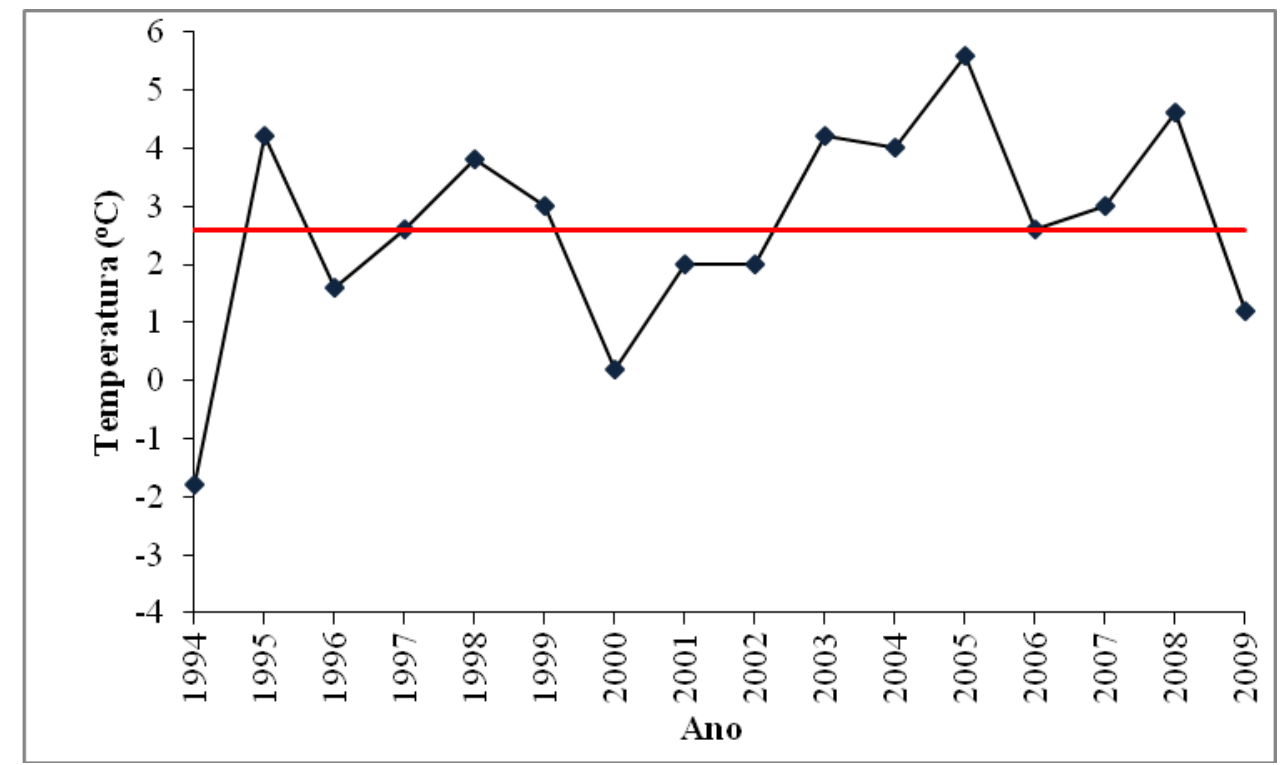

Gráfico 29 - Temperatura mínima anual no município de Rio Claro/SP para os anos de 1994 a 2009. 


\subsubsection{4 - Temperatura média máxima}

Sobre o comportamento anual da temperatura média máxima é possível verificar que não houve variabilidade estatística significativa para o período 1994-2009. De acordo com a Tabela 24 e o Gráfico 30, a média para o período é de $28,5^{\circ} \mathrm{C}$, com máxima de $29,2^{\circ} \mathrm{C}$ em 2002 e a mínima de $27,6^{\circ} \mathrm{C}$ em 2004 , indicando uma estabilidade térmica para essa variável.

Tabela 24 - Valores da temperatura média máxima anual no município de Rio Claro/SP para a série temporal de 1994 a 2009.

\begin{tabular}{cc}
\hline Ano & T méd Max $\left({ }^{\mathbf{0}} \mathbf{)}\right)$ \\
\hline 1994 & 28,7 \\
1995 & 28,5 \\
1996 & 28,1 \\
1997 & 28,5 \\
1998 & 28,3 \\
1999 & 28,4 \\
2000 & 28,5 \\
2001 & 28,8 \\
2002 & 29,2 \\
2003 & 28,7 \\
2004 & 27,7 \\
2005 & 28,5 \\
2006 & 28,7 \\
2007 & 28,8 \\
2008 & 28,1 \\
2009 & 28,1 \\
Med & $\mathbf{2 8 , 5}$ \\
\hline
\end{tabular}

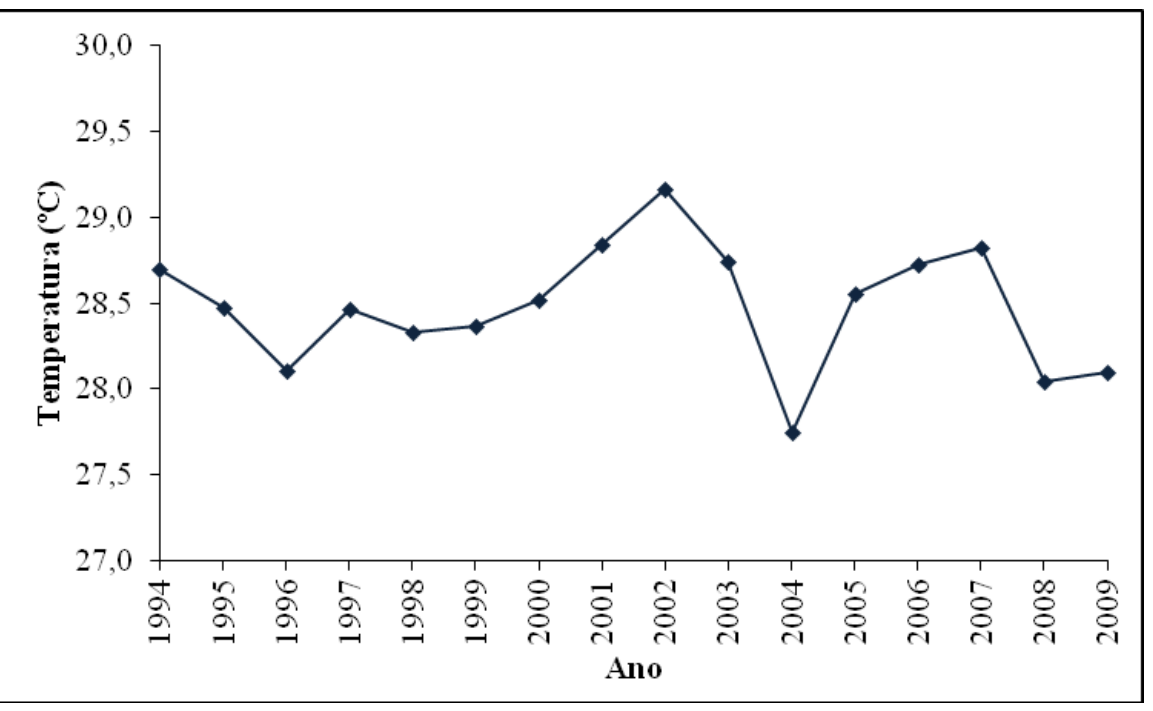

Gráfico 30 - Temperatura média máxima anual no município de Rio Claro/SP para os anos de 1994 a 2009. 


\subsubsection{5 - Temperatura média mínima}

Durante o período a temperatura média mínima oscilou entre os valores de $15^{\circ} \mathrm{C} \mathrm{em}$ 1999 e $16,7^{\circ} \mathrm{C}$, em 2004 , com uma média de $15,6^{\circ} \mathrm{C}$ para o período, não se verificando variabilidade para a série, conforme mostram a Tabela 25 e o Gráfico 31.

Tabela 25 - Valores da temperatura média mínima anual no município de Rio Claro/SP para a série temporal de 1994 a 2009.

\begin{tabular}{cc}
\hline Ano & Tméd mín $\left({ }^{\mathbf{0}} \mathbf{C}\right)$ \\
\hline 1994 & 15,3 \\
1995 & 15,5 \\
1996 & 15,3 \\
1997 & 15,6 \\
1998 & 16,1 \\
1999 & 15,0 \\
2000 & 15,7 \\
2001 & 16,0 \\
2002 & 16,7 \\
2003 & 15,4 \\
2004 & 15,3 \\
2005 & 16,1 \\
2006 & 15,3 \\
2007 & 15,7 \\
2008 & 15,4 \\
2009 & 15,8 \\
Med & $\mathbf{1 5 , 6}$ \\
\hline
\end{tabular}

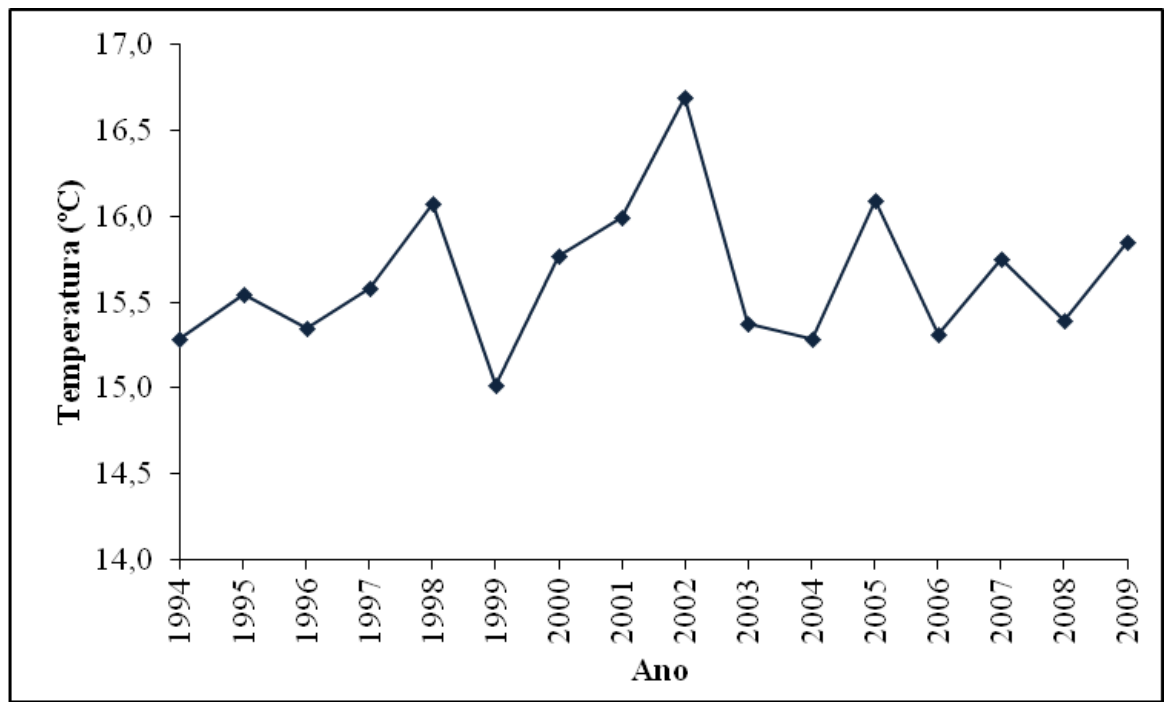

Gráfico 31 - Temperatura média mínima anual no município de Rio Claro/SP para os anos de 1994 a 2009. 


\subsection{2 - Análise da tendência para as temperaturas médias, máximas, mínimas, média máxima e média mínima: retas de regressão.}

A temperatura média para o período apresenta tendência de crescimento correspondente a um aumento de $0,0363^{\circ} \mathrm{C} / \mathrm{ano}$. O ano de 2002 , com temperatura média de $23,7^{\circ} \mathrm{C}$, foi o mais quente, enquanto 1996 , com temperatura de $22,3^{\circ} \mathrm{C}$, mostrou-se o mais frio, apresentado uma amplitude térmica de $1,4^{\circ} \mathrm{C}$ para o período. $\mathrm{O}$ coeficiente de determinação é igual a 0,1874 , explicando que a reta da temperatura média em relação ao tempo se ajusta em apenas 18,7\%, conforme mostra o Gráfico 32. No mesmo gráfico, a reta de tendência aponta para um acréscimo de aproximadamente $0,57^{\circ} \mathrm{C}$ na temperatura média anual durante o período, determinando, portanto, a ausência de tendência.

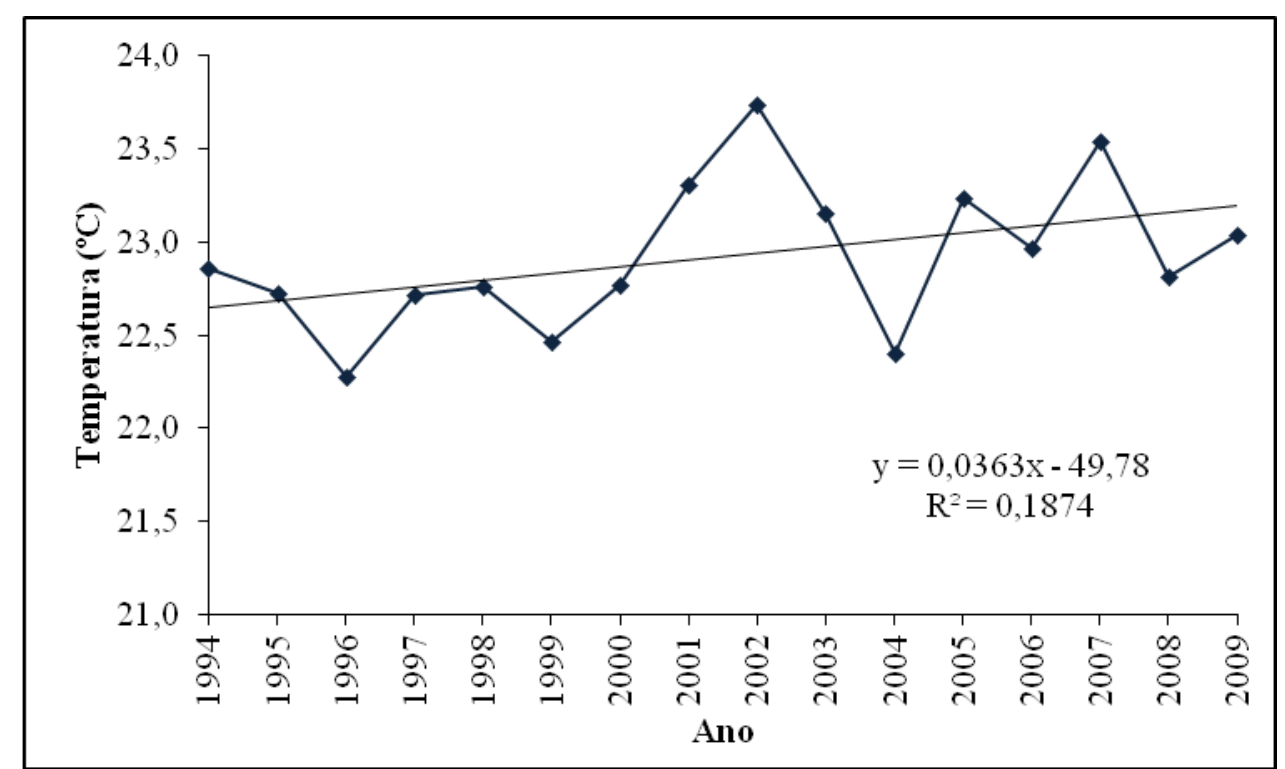

Gráfico 32 - Reta de regressão para a temperatura média anual no município de Rio Claro/SP para os anos de 1994 a 2009.

O Gráfico 33 mostra a reta ajustada para o período com uma pequena tendência de acréscimo, evidenciada pelo coeficiente angular e uma propensão à elevação da temperatura máxima à razão de $0,0415^{\circ} \mathrm{C} / \mathrm{ano}$, caracterizando-se como tendência insignificante. A maior temperatura máxima, $38,4^{\circ} \mathrm{C}$, ocorreu em 2002 , e a menor, em 1996 , com valor de $34,4^{\circ} \mathrm{C}$, resultando em uma amplitude térmica de $4,0^{\circ} \mathrm{C}$, para o período. Pode-se observar que a reta de tendência aponta para um aumento de $0,66^{\circ} \mathrm{C}$ e na temperatura máxima durante os dezesseis anos de observação da série considerada, com tendência também pouco 
significativa. Verifica-se, também, que a reta não se ajustou bem aos dados, fato demonstrado pelo baixíssimo coeficiente de determinação $\mathrm{R}^{2}$ igual a 0,0345 .

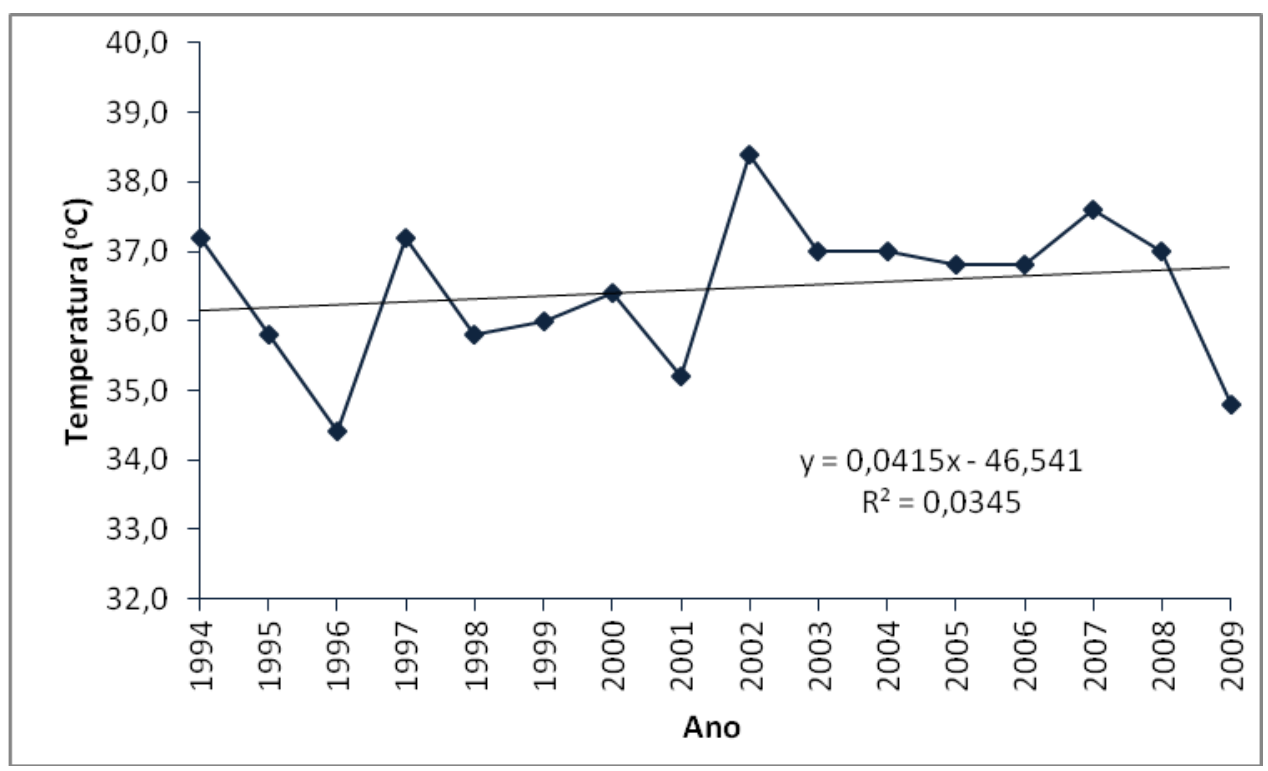

Gráfico 33 - Reta de regressão para a temperatura máxima anual no município de Rio Claro/SP para os anos de 1994 a 2009.

A análise do Gráfico 34, relativo à temperatura mínima, indica que ocorre uma tendência de aumento à razão de $0,14^{\circ} \mathrm{C} /$ ano, com $\mathrm{R}^{2}=0,1318$, cujo valor de aproximadamente $13 \%$ mostra-se muito baixo, indicando que a reta não se ajusta muito bem aos dados da série. A maior temperatura mínima foi de $5,6^{\circ} \mathrm{C}$ em 2005 e a menor, $-1,8^{\circ} \mathrm{C}$, em 1994, estabelecendo uma amplitude de $7,4^{\circ} \mathrm{C}$ para a série, em um intervalo de onze anos A tendência de aumento das temperaturas mínimas sugere a diminuição do número de noites frias para os últimos anos da série, visto que as menores temperaturas diárias ocorrem sempre na madrugada. Observa-se que a reta de tendência aponta para um aumento de $2,2^{\circ} \mathrm{C}$ nos valores das temperaturas mínimas durante os dezesseis anos de observação da série considerada, com tendência de crescimento crescente dessa variável. 


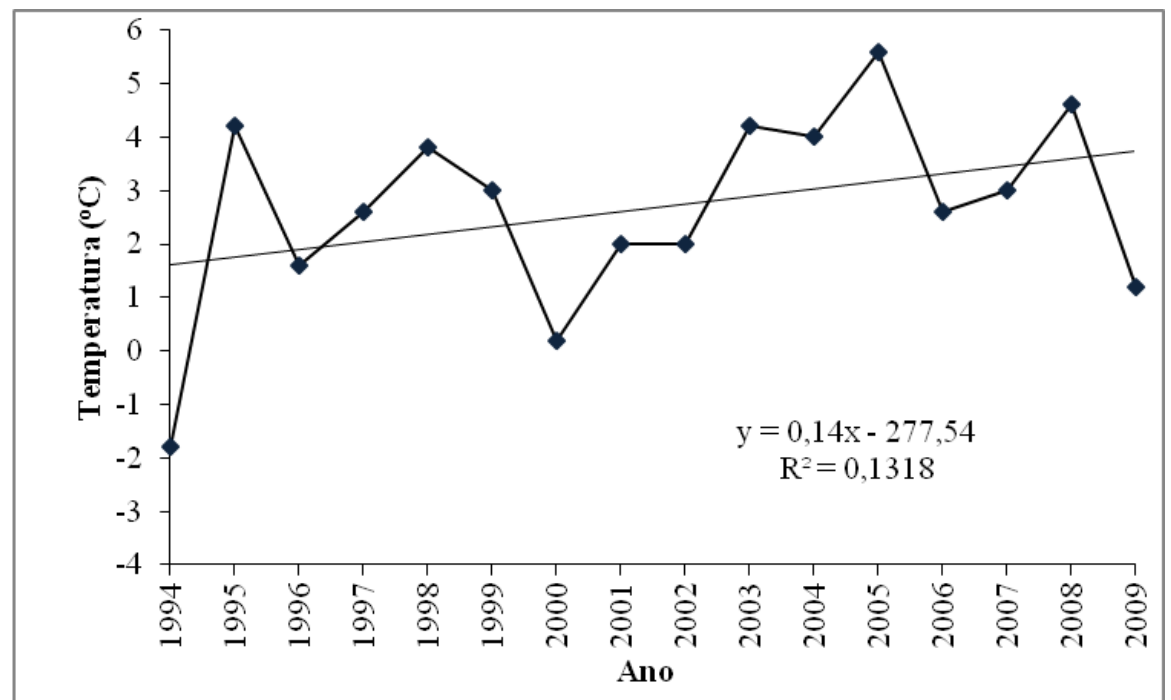

Gráfico 34 - Reta de regressão para a temperatura mínima anual no município de Rio Claro/SP para os anos de 1994 a 2009.

Em relação ao Gráfico 35, a temperatura média máxima aponta para uma tendência de decréscimo, à taxa de $0,0075^{\circ} \mathrm{C}$ ao ano, contabilizando $0,12^{\circ} \mathrm{C}$ ao longo da série de dezesseis anos, para um coeficiente de determinação da reta ajustada aos dados, $\mathrm{R}^{2}=0,0097$, indicando que quase nenhuma variação da temperatura média máxima está bem associada à variação temporal. $\mathrm{O}$ valor do acréscimo total da temperatura e a inclinação da reta evidenciam tendência pouco significativa, podendo ser considerada como estabilidade. A maior temperatura registrada foi de $29,2^{\circ} \mathrm{C}$ em 2002 e a menor, $27,6^{\circ} \mathrm{C}$, em 2004 . Pode-se afirmar, então, que, pela medida estatística da reta de regressão, essa variável não apresenta tendência significativa.

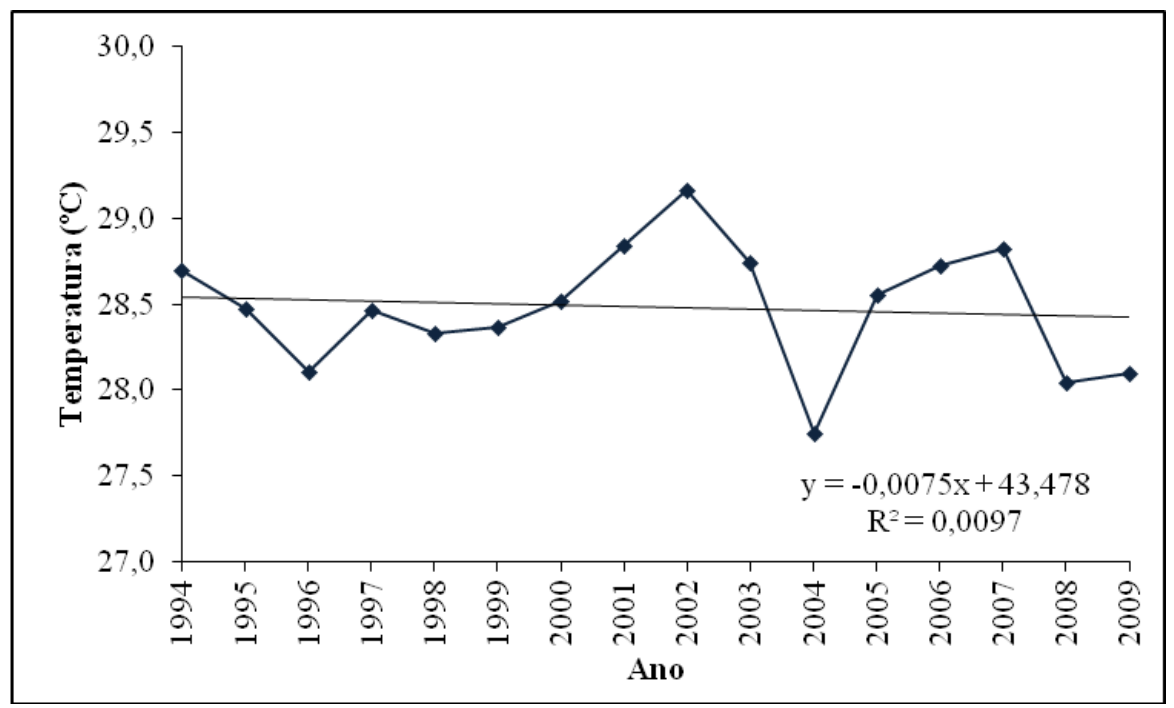

Gráfico 35 - Reta de regressão para a temperatura média máxima anual no município de Rio Claro/SP para os anos de 1994 a 2009. 
A reta de regressão do Gráfico 36 aponta para uma mínima inclinação positiva nos valores da temperatura média mínima, à taxa de $0,0138^{\circ} \mathrm{C} /$ ano, totalizando $0,22^{\circ} \mathrm{C}$ para a série toda, mostrando que a tendência dessa variável é muito pouco significativa, apontando para a estabilidade. A maior temperatura média mínima, de $16,7^{\circ} \mathrm{C}$, ocorreu em 2004 e a menor, $15^{\circ} \mathrm{C}$, em 1999, resultando em uma amplitude térmica de $1,7^{\circ} \mathrm{C}$. Com o valor de $\mathrm{R}^{2}=0,0243$ fica evidente que a reta de regressão não foi bem ajustada aos dados, em razão da ausência de uma propensão manifestada pela temperatura.

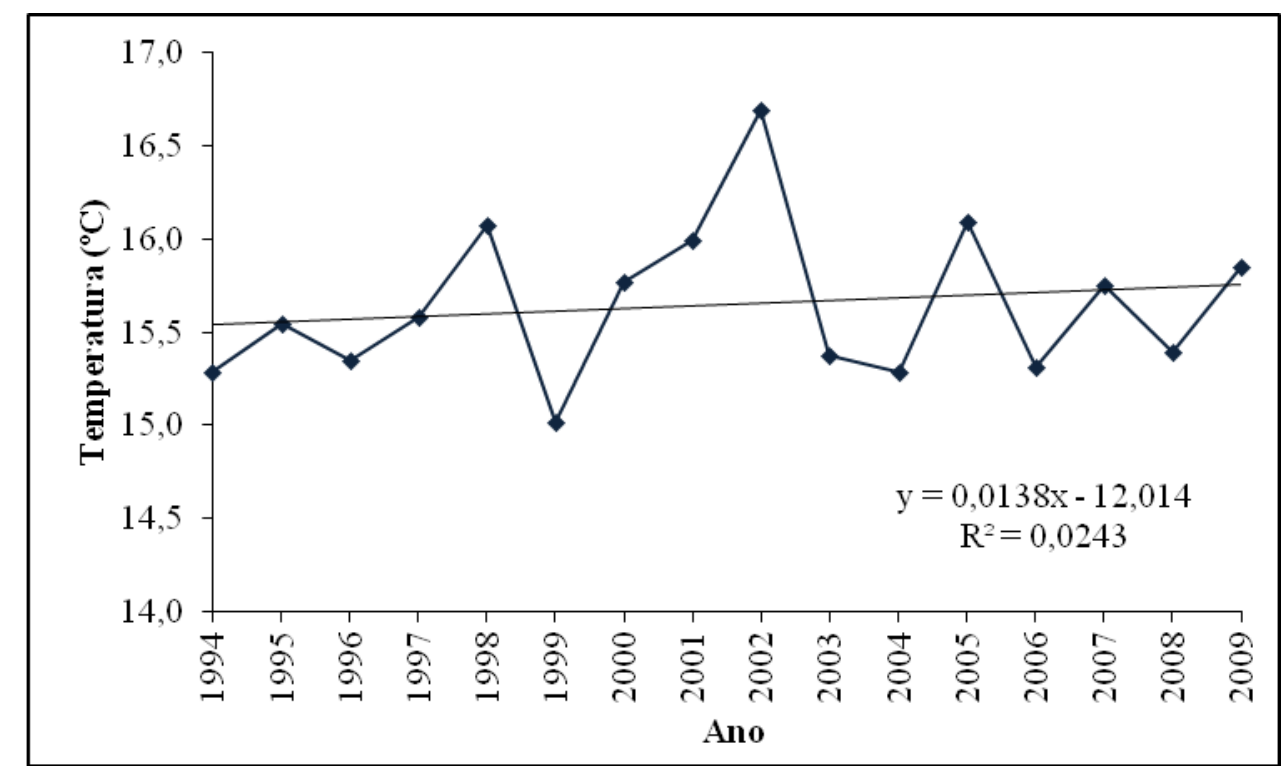

Gráfico 36 - Reta de regressão para a temperatura média mínima anual no município de Rio Claro/SP,para os anos de 1994 a 2009.

\subsection{3 - Análise da variabilidade para a pluviosidade}

Para a série temporal estudada (1994 a 2009) registrou-se o total anual médio de 1458,9 mm, sendo 2004 o ano mais chuvoso $(1742,4 \mathrm{~mm})$, e 2001, o menos chuvoso (1186,4 mm), conforme Tabela 26. 
Tabela 26 - Valores da pluviosidade total anual no município de Rio Claro/SP para a série temporal de 1994 a 2009.

\begin{tabular}{cc}
\hline Ano & Pluvisidade (mm) \\
\hline 1994 & 1243,5 \\
1995 & 1677,9 \\
1996 & 1700,8 \\
1997 & 1458,7 \\
1998 & 1288,7 \\
1999 & 1601,7 \\
2000 & 1532,7 \\
2001 & 1186,4 \\
2002 & 1534,1 \\
2003 & 1336,2 \\
2004 & 1742,4 \\
2005 & 1416,6 \\
2006 & 1354,3 \\
2007 & 1433,3 \\
2008 & 1192,9 \\
2009 & 1643,6 \\
Med & $\mathbf{1 4 5 8 , 9}$ \\
\hline
\end{tabular}

A Tabela 27 mostra o comportamento mensal da pluviosidade e a análise do período escolhido evidencia a distribuição não homogênea ao longo do ano.Verifica-se também a ocorrência de quatro meses (junho, julho, agosto e setembro) sem a incidência de chuvas ao longo da série. A estação com menor precipitação (seca) ocorre, em geral, no outono e inverno, abrangendo os meses de abril a setembro, decorrente do clima tropical da região.

Os meses da estação menos chuvosa em geral apresentam pluviosidades médias mensais abaixo de $60 \mathrm{~mm}$. Já o período compreendido entre o primeiro trimestre (janeiro, fevereiro e março) e o último trimestre (outubro, novembro e dezembro), apresenta valores médios de pluviosidade acima de $100 \mathrm{~mm}$. O trimestre menos chuvoso, constituído pelos meses de junho, julho e agosto, apresentou pluviosidade média abaixo dos $40 \mathrm{~mm}$.

Os meses maio, junho, julho e agosto registraram valores da pluviosidade mínima igual a zero ou próximo de zero. As máximas pluviosidades ocorreram nos meses de novembro, dezembro, janeiro e fevereiro, com precipitação média de 226,6 mm para esses meses, verificando-se também as máximas pluviosidades para dezembro $(220,6 \mathrm{~mm})$, janeiro $(299,8 \mathrm{~mm})$ e fevereiro $(224,9 \mathrm{~mm})$.

A pluviosidade média anual no período foi de $1458,9 \mathrm{~mm}$, sendo verificado um desvio padrão de 182,8 mm e coeficiente de variação de 12\%, conforme a Tabela 27. 
A grande variabilidade da pluviosidade no período pode ser verificada pelos seus valores que oscilaram, principalmente, entre $1100 \mathrm{~mm}$ e $1700 \mathrm{~mm}$.

Tabela 27 - Valores da média, desvio padrão (DP) e coeficiente de variação (CV) da pluviosidade média anual e mensal no município de Rio Claro/SP para os anos de 1994 a 2009.

\begin{tabular}{cccccc}
\hline Anual/mensal & $\begin{array}{c}\text { Média } \\
(\mathrm{mm})\end{array}$ & $\begin{array}{c}\text { DP } \\
(\mathrm{mm})\end{array}$ & $\begin{array}{c}\text { CV } \\
(\%)\end{array}$ & $\begin{array}{c}\text { Max } \\
(\mathrm{mm})\end{array}$ & $\begin{array}{c}\text { Min } \\
(\mathrm{mm})\end{array}$ \\
\hline jan & 299,8 & 114,64 & 38 & 485,2 & 110,8 \\
fev & 224,9 & 110,52 & 49 & 506,1 & 72,6 \\
mar & 149,5 & 44,07 & 29 & 214,1 & 58,2 \\
abr & 64,4 & 47,36 & 73 & 175,3 & 4,1 \\
mai & 56,7 & 29,28 & 51 & 94,7 & 2,7 \\
jun & 39,1 & 55,25 & 137 & 230,8 & 0 \\
jul & 30,5 & 44,77 & 146 & 168,8 & 0 \\
ago & 31,2 & 37 & 118 & 125,8 & 0 \\
set & 63,7 & 52,96 & 83 & 192,6 & 0,6 \\
out & 115,7 & 35,4 & 30 & 182,6 & 50,8 \\
nov & 161,3 & 77,11 & 47 & 288,2 & 28,1 \\
dez & 220,6 & 42,31 & 19 & 332,3 & 142,3 \\
anual & $\mathbf{1 4 5 8 , 9}$ & $\mathbf{1 8 2 , 8}$ & $\mathbf{1 2}$ & $\mathbf{1 7 4 2 , 4}$ & $\mathbf{1 1 8 6 , 4}$ \\
\hline
\end{tabular}

O Gráfico 37 mostra a distribuição temporal da pluviosidade total anual para o período estudado. O gráfico permite constatar que a pluviosidade anual apresentou-se bem distribuída ao longo da série, chamando a atenção para os máximos valores registrados nos anos de 1996 e 2004. A pluviosidade anual média nesse período é de 1458,9 mm, valor um pouco acima da normal climatológica $1352 \mathrm{~mm}$, determinada pelo INMET. Em relação aos dados referentes aos dezesseis anos de observação, apenas sete anos registraram pluviosidade acima da média; os nove anos restantes, abaixo da média, indicação de grande variabilidade. 


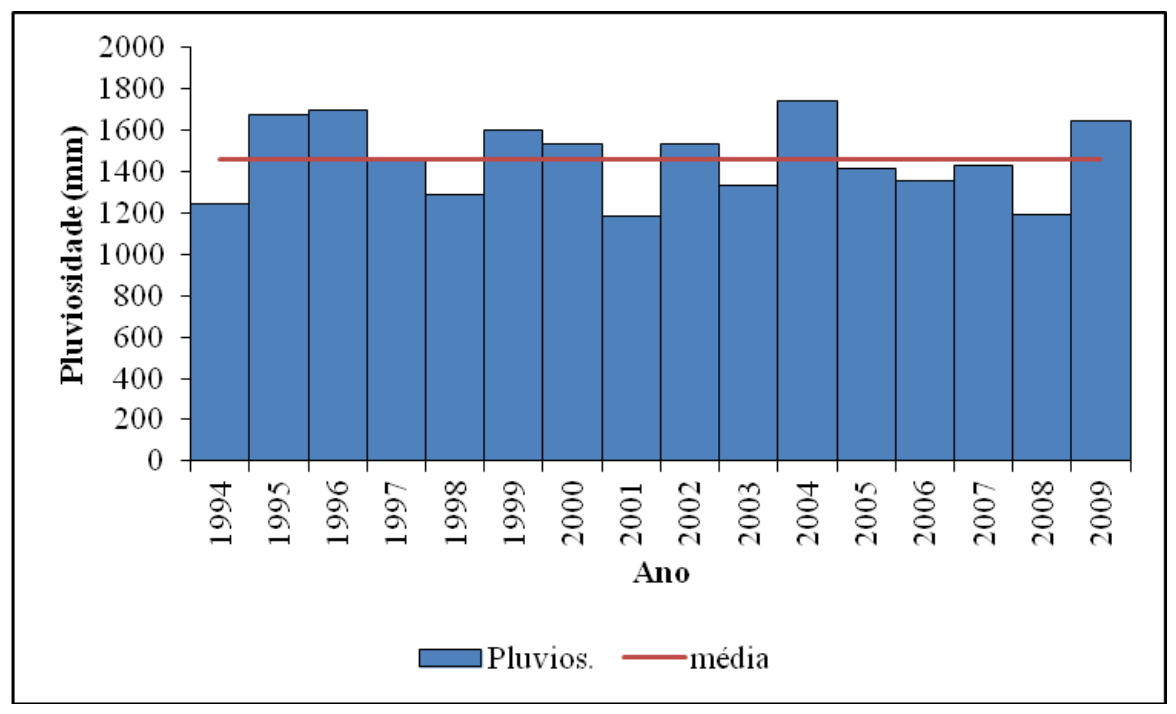

Gráfico 37 - Pluviosidade total anual de Rio Claro/SP de 1994 a 2009

A curva do Gráfico 38 tem o objetivo de mostrar, também, a variabilidade da chuva em intervalos menores, apresentando períodos de dispersões acentuadas. Portanto, o polinômio de quinto grau ajustado à série de dados anuais aponta para a grande variabilidade do fenômeno que, ao longo da série, apresentou valores oscilando entre 1100 e 1700 mm, com exceção dos 1996 e 2004, que apresentaram valores acima de $1700 \mathrm{~mm}$.

A análise de períodos mais curtos ao longo da série evidencia que a curva indica variabilidades crescentes entre 1994 a 1996, decrescendo acentuadamente de 1996 a 1998. Entre 2001 e 2004 volta a ter um comportamento crescente, com um máximo em 2004; e, após um valor decrescente em 2008, volta a crescer acentuadamente até 2009, evidenciando com mais clareza a variabilidade do regime de chuvas para a localidade.

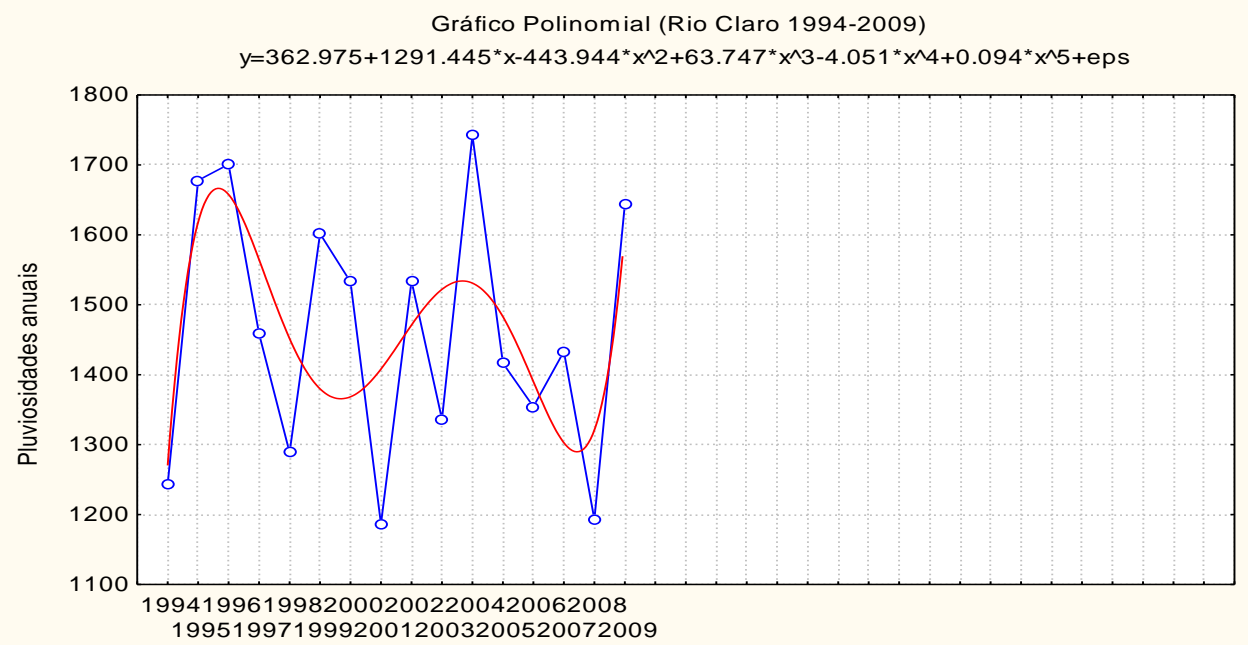

Gráfico 38 - Pluviosidade total anual de Rio Claro/SP de 1994 a 2009, Curva de Regressão polinomial de grau 5. 


\subsection{4 - Análise da tendência para a pluviosidade: reta de regressão}

O Gráfico 39 mostra a reta de tendência para a pluviosidade: a inclinação da reta de regressão mostra que houve um decréscimo de 4,1597 mm/ano de chuva ao longo da série, perfazendo um total de $66,5 \mathrm{~mm}$, o que pode ser considerado como pequena diminuição nos valores da pluviosidade no período considerado.

A análise dos dados indica então uma tendência de diminuição nos valores da precipitação na localidade. $O$ valor do coeficiente de determinação $\left(R^{2}=0,0117\right)$ mostra também que a reta de regressão não está bem ajustada aos dados; portanto, quase nenhuma variação da pluviosidade esteve bem associada ao tempo. Os dados obtidos permitem reconhecer a ausência de mudança no tipo de clima. A pequena tendência à diminuição observada no comportamento da pluviosidade, mesmo levando-se em conta alguns extremos, está relacionada às variações na oscilação e intensidade das massas de ar e relevo local.

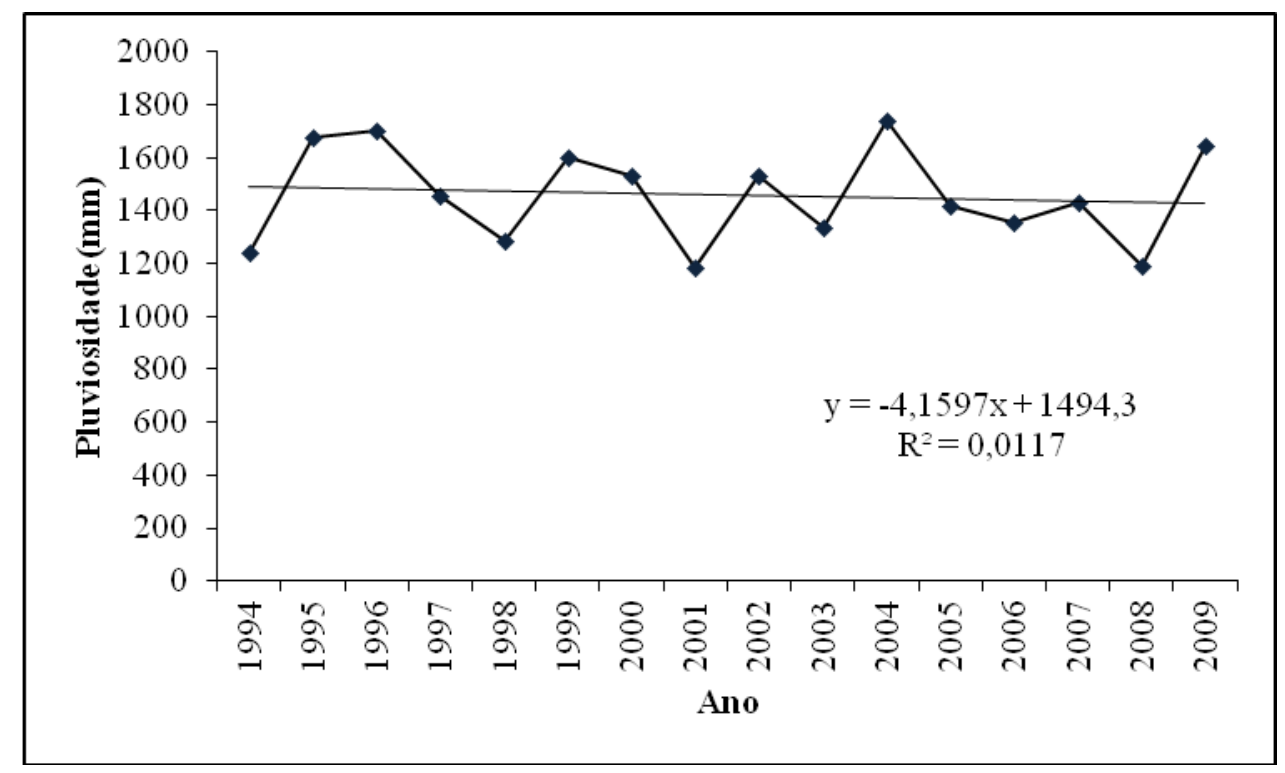

Gráfico 39 - Tendência da pluviosidade total anual no município de Rio Claro/SP no período de 1994 a 2009 - reta de regressão. 


\subsection{5 - Análise da tendência para a temperatura e pluviosidade: teste de Mann-Kendall e curvatura de Sen.}

\subsubsection{1 - Medidas estatísticas das temperaturas máximas, médias máximas, mínimas, médias mínimas, médias e pluviosidade em Rio Claro no período de 1994-2009.}

Utilizando os aplicativos estatísticos Statistica e BioEstat foram obtidos resultados apresentados abaixo para a cidade de Rio Claro, no período de 1994-2009.

Tabela 28 - Medidas estatísticas de temperatura máxima, temperatura média máxima, temperatura mínima, temperatura média mínima, temperatura média e pluviosidade ) para Rio Claro/SP.

\begin{tabular}{|l|c|c|c|c|c|}
\hline \multirow{4}{*}{ Estatística } & \multicolumn{5}{|c|}{ Variáveis Meteorológicas } \\
\cline { 2 - 6 } & $\begin{array}{c}\text { temperatura } \\
\text { máxima } \\
\left({ }^{\circ} \mathrm{C}\right)\end{array}$ & $\begin{array}{c}\text { temperatura } \\
\text { média máxima } \\
\left({ }^{\circ} \mathrm{C}\right)\end{array}$ & $\begin{array}{c}\text { temperatura } \\
\text { mínima } \\
\left({ }^{\circ} \mathrm{C}\right)\end{array}$ & $\begin{array}{c}\text { temperatura } \\
\text { média mínima } \\
\left({ }^{\circ} \mathrm{C}\right)\end{array}$ & $\begin{array}{c}\text { pluviosidade } \\
(\mathrm{mm})\end{array}$ \\
\hline Mínimo & 32,27 & 27,74 & 9,70 & 15,02 & 1186,40 \\
Máximo & 33,87 & 29,17 & 11,81 & 16,70 & 1742,40 \\
MA & 33,06 & 28,48 & 10,73 & 15,64 & 1458,98 \\
DP & 0,4567 & 0,3622 & 0,6487 & 0,4224 & 182,806 \\
CV & 1,38 & 1,27 & 6,04 & 2,70 & 12,53 \\
Assim. & $-0,1277$ & $-0,2510$ & $-0,1346$ & 0,373 & 0,0036 \\
Curtose & $-0,7032$ & 0,0440 & $-0,6887$ & 1,0664 & $-1,2387$ \\
\hline
\end{tabular}

Onde: M.A. = Média Aritmética; DP = Desvio Padrão; CV = Coeficiente de Variação; Assim. $=$ coeficiente de assimetria Curtose $=$ Coeficiente de Curtose .

A análise da Tabela 28 mostra que há certa proximidade entre as medidas estatísticas Mínimo, Máximo e M.A. para as temperaturas, mas não ocorre o mesmo com a pluviosidade. O comportamento das medidas de variabilidade: desvio padrão (DP) e coeficiente de variação $\mathrm{CV}(\%)$ são baixos para as séries, indicando pouca variabilidade entre os dados de cada coluna. Em relação à assimetria, todas as séries são classificadas como assimétricas. As séries, temperatura máxima, média máxima e mínima, são assimétricas à esquerda, pois apresentam os coeficientes do momento de assimetria negativos, enquanto as séries para temperatura média mínima e pluviosidade são classificadas como assimétricas à direita ou positiva. Em relação à curtose, todas as distribuições são classificadas como platicúrticas, pois as medidas das colunas são menores que 3 . 


\subsubsection{2 - Análises das tendências e das estimativas}

A seguir apresentam-se os resultados das análises das variáveis meteorológicas a partir dos testes estatísticos de Mann-Kendall (MK) e Curvatura de Sen (CS), considerando-se o nível de confiança de $95 \%$ ou $\alpha=5 \%$.

Tabela 29 - Análise Estatística das Variáveis Meteorológicas $(\alpha=5 \%)$ para Rio Claro/SP.

\begin{tabular}{|l|c|c|c|c|c|c|}
\hline \multirow{3}{*}{ Estatística } & \multicolumn{6}{|c|}{ Variáveis Meteorológicas } \\
\cline { 2 - 7 } & $\begin{array}{c}\text { temperatura } \\
\text { máxima } \\
\left({ }^{\circ} \mathrm{C}\right)\end{array}$ & $\begin{array}{c}\text { temperatura } \\
\text { média máxima } \\
\left({ }^{\circ} \mathrm{C}\right)\end{array}$ & $\begin{array}{c}\text { temperatura } \\
\text { mínima } \\
\left({ }^{\circ} \mathrm{C}\right)\end{array}$ & $\begin{array}{c}\text { temperatura } \\
\text { média mínima } \\
\left({ }^{\circ} \mathrm{C}\right)\end{array}$ & $\begin{array}{c}\text { temperatura } \\
\text { média } \\
\left({ }^{\circ} \mathrm{C}\right)\end{array}$ & $\begin{array}{c}\text { pluviosidade } \\
(\mathrm{mm})\end{array}$ \\
\hline Escore Z & $-0,0412$ & 0,2060 & 0,7828 & 0,1236 & 1,6347 & $-0,9474$ \\
MK & $-0,0147$ & 0,0441 & 0,1471 & 0,0294 & 0,3083 & $-0,1765$ \\
CS & $-0,0012$ & 0,0076 & 0,0249 & 0,0025 & 0,0333 & $-17,4542$ \\
Prob. $(\mathrm{p})$ & 0,9671 & 0,8368 & 0,4338 & 0,9016 & 0,1021 & 0,3434 \\
\hline
\end{tabular}

A partir da Tabela 29, é possível verificar que:

Para os resultados das colunas das temperaturas médias máximas, mínimas, médias mínimas e médias há tendências positivas, pois os valores das medidas de Mann-Kendall (MK) são, respectivamente, 0,0041, 0,1471, 0,0294 e 0,3083, com Z>0, mas todas as colunas insignificantes, pois p>0,05. As tendências dessas variáveis (anuais), determinadas pelos valores da Curvatura de Sen é de aumentar aproximadamente $0,0076^{\circ} \mathrm{C}, 0,0249^{\circ} \mathrm{C}, 0,0025^{\circ} \mathrm{C}$ e $0,0333^{\circ} \mathrm{C}$ por ano. As colunas das temperaturas máximas e pluviosidade apresentaram tendências decrescentes, com Mann-Kendall igual a -0,0147 e -0,1765, mas também insignificante, $\operatorname{com} \mathrm{Z}<0$ e p >0,05. A tendência da temperatura máxima é de decrescimento à taxa de $0,0412^{\circ} \mathrm{C} / \mathrm{ano}$ (Curvatura de Sen).

Para a pluviosidade anual, embora insignificante por MK, ocorreu uma tendência mais acentuada, podendo ser constatado um decréscimo de 17,4542 mm/ ano, observando-se a medida determinada pela curvatura de Sen, no total de $279,2 \mathrm{~mm}$ para a série toda. Comparando-se esse resultado com o obtido do Gráfico 39 (reta de regressão), constata-se coerência quanto à tendência no declínio da pluviosidade, embora tenha ocorrido uma diferença nas magnitudes, pois o coeficiente angular determinou uma taxa de decréscimo de 4,1597 mm/ano. Comparando-se também os resultados por MK e Curvatura de Sen com a reta de regressão do Gráfico 32 para as temperaturas médias, verifica-se que, pelos dois métodos, 
houve tendência de crescimento, cujas magnitudes são iguais $0,0333^{\circ} \mathrm{C} / a n o$ (Sen) e $0,0363^{\circ} \mathrm{C} /$ ano (coeficiente angular).

5.4 - Análise dos dados de temperatura e pluviosidade da série temporal de 1994 a 2009 para São Carlos/SP.

\subsection{1 - Análise da variabilidade da temperatura}

\subsubsection{1 - Temperatura média}

De acordo com a Tabela 30 a análise do comportamento anual da temperatura durante a série temporal considerada (1994-2009) mostra que a média anual do período é de $21,8^{\circ} \mathrm{C}$, com média mais elevada de $23,4^{\circ} \mathrm{C}$, registrada em 1994 , e a média mais baixa de $19,7^{\circ} \mathrm{C}$, em 1999, com pequena amplitude térmica, de $3,7^{\circ} \mathrm{C}$, indicando uma pequena variabilidade, pois os valores encontrados para os outros anos da série oscilam em torno da situação média.

Tabela 30 - Valores da temperatura média anual no município de São Carlos/SP para a série temporal de 1994 a 2009.

\begin{tabular}{cc}
\hline Ano & Tméd( $\left.{ }^{\mathbf{}} \mathbf{C}\right)$ \\
\hline 1994 & 23,4 \\
1995 & 22,1 \\
1996 & 21,7 \\
1997 & 22,1 \\
1998 & 22,7 \\
1999 & 19,7 \\
2000 & 21,5 \\
2001 & 21,6 \\
2002 & 22,8 \\
2003 & 21,7 \\
2004 & 20,2 \\
2005 & 22,5 \\
2006 & 22,6 \\
2007 & 21,9 \\
2008 & 21,4 \\
2009 & 21,1 \\
Med & $\mathbf{2 1 , 8}$ \\
\hline
\end{tabular}


Em relação ao comportamento mensal da temperatura média, a Tabela 31 mostra que o primeiro e o último trimestres do ano, representam os períodos com temperaturas mais elevadas, sendo fevereiro o mês mais quente, com média mensal de $24,3^{\circ} \mathrm{C}$, desvio padrão de $1,3^{\circ} \mathrm{C}$, coeficiente de variação de $5,3 \%$, temperatura média máxima igual a $26,3^{\circ} \mathrm{C}$ e média mínima de $21,7^{\circ} \mathrm{C}$. Os meses de maio, junho, julho e agosto representam o período do ano com temperaturas menos elevadas, sendo junho o mês mais frio, com temperatura média de $17,7^{\circ} \mathrm{C}$, desvio padrão de $2,3^{\circ} \mathrm{C}$, coeficiente de variação de $13 \%$, temperatura média máxima de $20,2^{\circ} \mathrm{C}$ e média mínima de $10,3^{\circ} \mathrm{C}$. Junho é o mês com maior coeficiente de variação $(\mathrm{CV}=13 \%)$, com a maior variabilidade para a temperatura média do ar; dezembro tem o menor coeficiente de variação $(\mathrm{CV}=1,8 \%)$, apresentando baixíssima variabilidade, ou seja, a temperatura manteve-se próxima de um valor constante para todos os meses de dezembro da série.

Tabela 31 - Valores da temperatura média, desvio padrão (DP) e coeficiente de variação (CV) da temperatura média anual e mensal no município de São Carlos/SP para os anos de 1994 a 2009.

\begin{tabular}{cccccc}
\hline Anual/mensal & $\begin{array}{c}\text { Méd Med } \\
\left({ }^{\mathbf{0}} \mathbf{C}\right)\end{array}$ & $\begin{array}{c}\text { DP } \\
\left({ }^{\mathbf{}} \mathbf{C}\right)\end{array}$ & $\begin{array}{c}\mathbf{C V} \\
(\boldsymbol{\%})\end{array}$ & $\begin{array}{c}\text { MaxMed } \\
\left({ }^{\mathbf{}} \mathbf{C}\right)\end{array}$ & $\begin{array}{c}\text { MinMed } \\
\left({ }^{\mathbf{}} \mathbf{C}\right)\end{array}$ \\
\hline jan & 23,7 & 1,1 & 4,7 & 25,9 & 21,2 \\
fev & 24,3 & 1,3 & 5,3 & 26,3 & 21,7 \\
mar & 23,9 & 1,2 & 5 & 25,8 & 21,5 \\
abr & 22,4 & 0,9 & 4,4 & 23,8 & 19,2 \\
mai & 19,1 & 1,2 & 6,4 & 21,1 & 16,2 \\
jun & 17,7 & 2,3 & 13 & 20,2 & 10,3 \\
jul & 18,2 & 1,2 & 6,4 & 21,6 & 17,1 \\
ago & 19,9 & 1,3 & 6,4 & 22,9 & 17,7 \\
set & 21,5 & 1,2 & 5,3 & 23,6 & 19,5 \\
out & 23,1 & 1,5 & 6,6 & 25,8 & 20,9 \\
nov & 23,8 & 2,5 & 10,7 & 32,5 & 21,1 \\
dez & 23,7 & 2,4 & 10,2 & 31,5 & 21,1 \\
Anual & $\mathbf{2 1 , 8}$ & $\mathbf{0 , 9}$ & $\mathbf{4 , 2}$ & $\mathbf{1 9 , 6}$ & $\mathbf{1 9 , 6}$ \\
\hline
\end{tabular}

A análise da distribuição desta variável climática ao longo da série (Gráfico 40) mostra que, dos dezesseis anos, oito apresentaram temperatura média anual acima da média da série, tendo os últimos três anos da série apontando para uma diminuição dos valores médios, verificando-se o desvio padrão de $0,9^{\circ} \mathrm{C}$ e o coeficiente de variação de 4,2\%, conforme a Tabela 31. O Gráfico 40 mostra também que a temperatura média apresentou pequena variabilidade. Excetuando-se os valores um pouco mais extremos, ocorridos em 1994 e 1999, os valores registrados para os outros anos foram bem próximos do valor médio. 


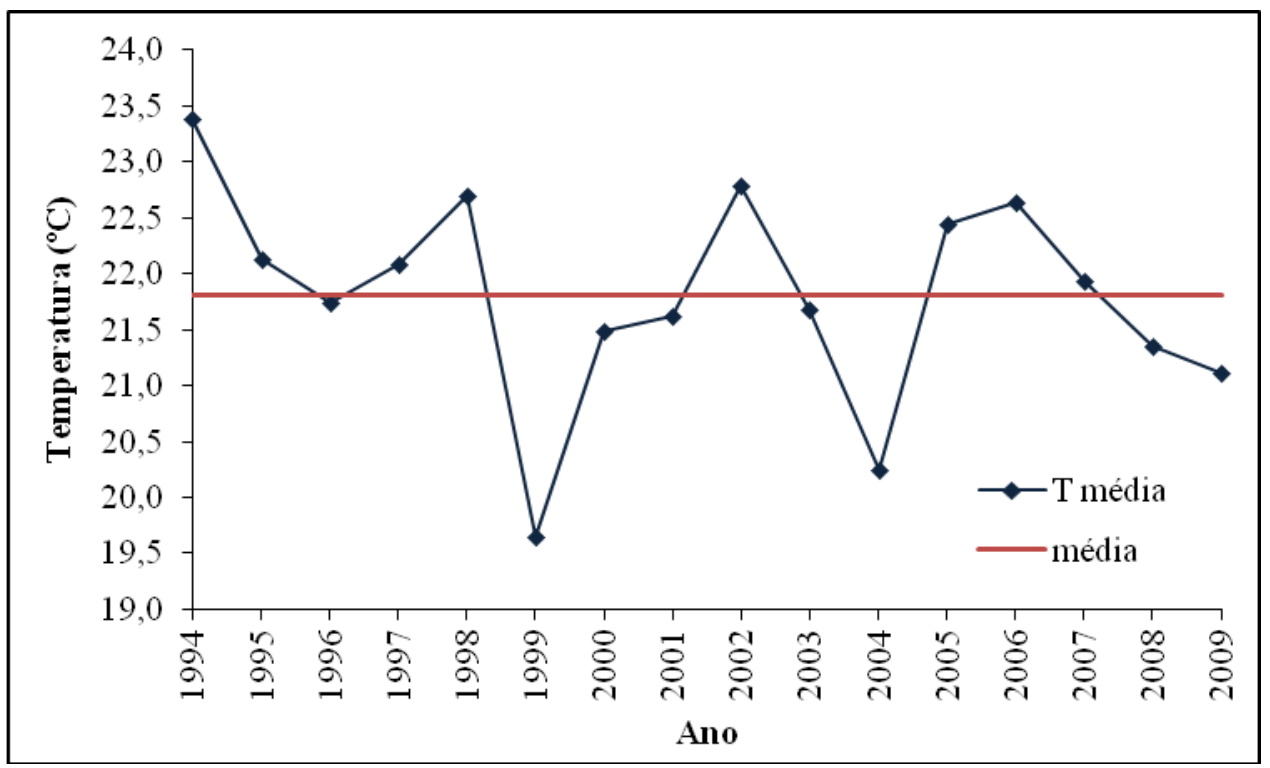

Gráfico 40 - Temperatura média anual no município de São Carlos/SP para os anos de 1994 a 2009.

\subsubsection{2 - Temperatura máxima}

A Tabela 32 mostra que a média das temperaturas máximas para o período é de $35,8^{\circ} \mathrm{C}$. A maior temperatura máxima, $39,7^{\circ} \mathrm{C}$, ocorreu em 2007 e a menor máxima, de $33,7^{\circ} \mathrm{C}$, em 1996. A amplitude térmica desse período resultou em $6^{\circ} \mathrm{C}$, indicando pequena variabilidade anual das temperaturas máximas, com valores oscilando em torno da média, exceto por dois valores bem abaixo da média e dois, bem acima.

Em relação ao comportamento mensal da temperatura máxima, Tabela 33, o mês de outubro é o mais quente da série, com temperatura média máxima de $34,7^{\circ} \mathrm{C}$, máxima de $37,4^{\circ} \mathrm{C}$ e mínima de $32,4^{\circ} \mathrm{C}$, com um desvio padrão de $1,6^{\circ} \mathrm{C}$ e coeficiente de variação de $4,5 \%$. Junho configurou-se como o mês mais frio, com temperatura média máxima de $28,5^{\circ} \mathrm{C}$, máxima de $30,5^{\circ} \mathrm{C}$, mínima de $26,3^{\circ} \mathrm{C}$, desvio padrão de $1,6^{\circ} \mathrm{C}$ e coeficiente de variação de $3,9 \%$. A amplitude térmica de $6,2^{\circ} \mathrm{C}\left(34,7^{\circ} \mathrm{C}-28,5^{\circ} \mathrm{C}\right)$, aponta para uma acentuada variabilidade climática entre esses meses do período considerado. 
Tabela 32 - Valores da temperatura máxima anual no município de São Carlos/SP para a série temporal de 1994 a 2009.

\begin{tabular}{cc}
\hline Ano & Tmáx $\left({ }^{\mathbf{O}} \mathbf{C}\right)$ \\
\hline 1994 & 35,6 \\
1995 & 34,8 \\
1996 & 33,7 \\
1997 & 35,6 \\
1998 & 34,3 \\
1999 & 35,0 \\
2000 & 36,4 \\
2001 & 33,8 \\
2002 & 37,4 \\
2003 & 39,2 \\
2004 & 35,4 \\
2005 & 34,8 \\
2006 & 35,6 \\
2007 & 39,7 \\
2008 & 36,4 \\
2009 & 35,0 \\
Med & $\mathbf{3 5 , 8}$ \\
\hline
\end{tabular}

Tabela 33 - Valores da temperatura máxima, desvio padrão (DP) e coeficiente de variação (CV) da temperatura média anual e mensal no município de São Carlos/SP para os anos de 1994 a 2009.

\begin{tabular}{cccccc}
\hline Anu/mens & $\begin{array}{c}\text { Méd Max } \\
\left({ }^{\mathbf{}} \mathbf{C}\right)\end{array}$ & $\begin{array}{c}\mathbf{D P} \\
\left({ }^{\mathbf{}} \mathbf{C}\right)\end{array}$ & $\begin{array}{c}\mathbf{C V} \\
(\mathbf{\%})\end{array}$ & $\begin{array}{c}\text { MaxMax } \\
\left({ }^{\mathbf{}} \mathbf{C}\right)\end{array}$ & $\begin{array}{c}\text { MinMax } \\
\left({ }^{\mathbf{}} \mathbf{C}\right)\end{array}$ \\
\hline jan & 33,5 & 1,2 & 3,5 & 36,2 & 32.0 \\
fev & 33,2 & 0,8 & 2,4 & 34,4 & 32,1 \\
mar & 33,4 & 1,3 & 3,7 & 36,4 & 31,3 \\
abr & 29,8 & 1,1 & 3,6 & 33,4 & 29,6 \\
mai & 29,7 & 1,1 & 3,4 & 31,1 & 27,2 \\
jun & 28,5 & 1,6 & 3,9 & 30,5 & 26,3 \\
jul & 29,3 & 1,3 & 4,5 & 31,7 & 26,3 \\
ago & 32,3 & 0,9 & 3 & 34,2 & 30,2 \\
set & 34,4 & 2,1 & 5,8 & 39,6 & 31,6 \\
out & 34,7 & 1,6 & 4,5 & 37,4 & 32,4 \\
nov & 33,7 & 1,2 & 3,5 & 35,6 & 31,6 \\
dez & 33,4 & 1,8 & 5,4 & 39,2 & 31,4 \\
Anual & $\mathbf{3 2 , 3}$ & $\mathbf{0 , 6}$ & $\mathbf{1 , 8}$ & $\mathbf{3 3 , 4}$ & $\mathbf{3 2 , 3}$ \\
\hline
\end{tabular}

A distribuição da temperatura máxima ao longo da série, conforme o Gráfico 41, mostra o registro de oito valores abaixo da média $\left(35,8^{\circ} \mathrm{C}\right)$, cinco acima da média e três 
valores coincidindo com média. Excetuando-se os dois valores um pouco mais extremos, em 2003 e 2007, a distribuição praticamente oscilou em torno do valor médio, com desvio padrão de $0,6^{\circ} \mathrm{C}$ e coeficiente de variação de $1,8 \%$, indicando baixa dispersão e também a inexistência de variabilidade, em acordo com o comportamento apresentado pela temperatura média.

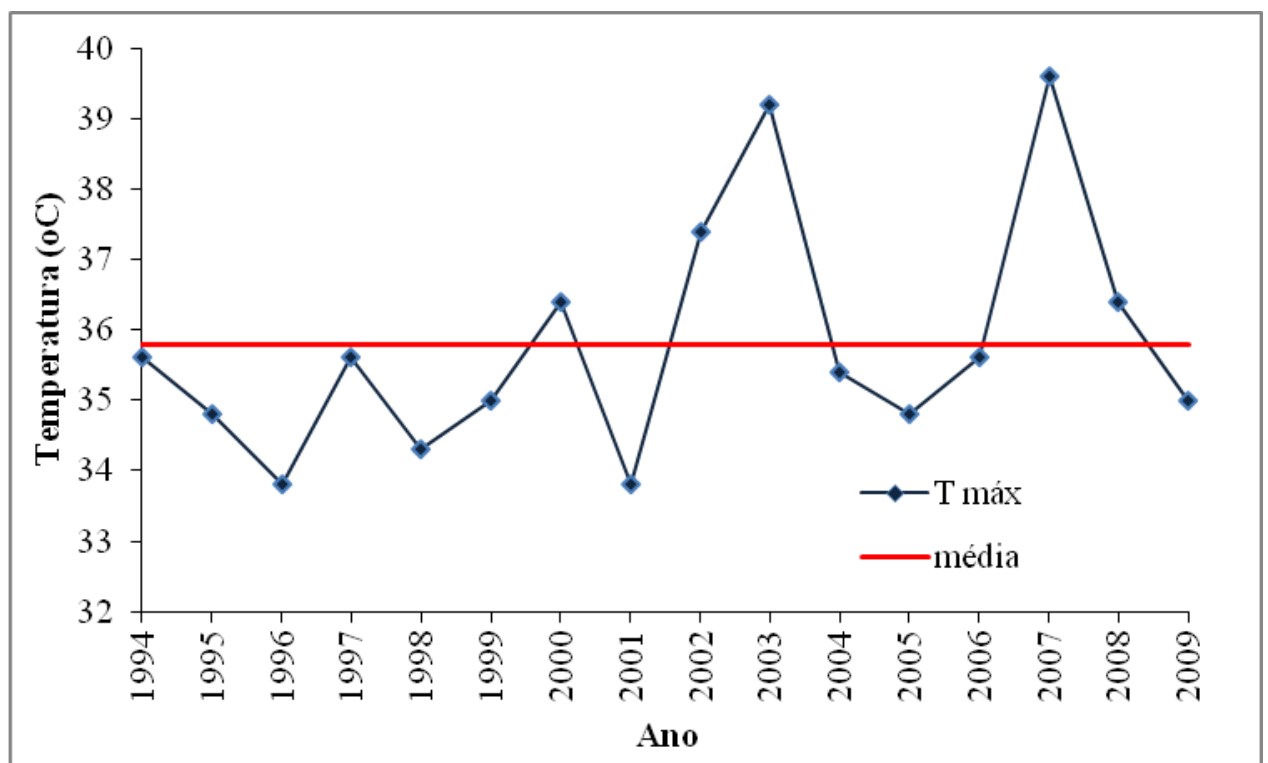

Gráfico 41 - Temperatura máxima anual no município de São Carlos/SP para os anos de 1994 a 2009.

\subsubsection{3 - Temperatura mínima}

Os dados da Tabela 34 mostram que a média das temperaturas mínimas é $1,0^{\circ} \mathrm{C}$, a menor temperatura mínima é $-3,3^{\circ} \mathrm{C}$, registrada em 1994 , e a maior, $4,3^{\circ} \mathrm{C}$, em 1995 , determinando uma amplitude térmica de $7,6^{\circ} \mathrm{C}$, entre os dois primeiros anos da série, o que indica uma variabilidade bem mais acentuada para a temperatura mínima anual em relação ao ocorrido com as temperatura média e a máxima. 
Tabela 34 - Valores da temperatura mínima anual no município de São Carlos/SP para a série temporal de 1994 a 2009.

\begin{tabular}{cc}
\hline Ano & Tmín $\left({ }^{\mathbf{C}} \mathbf{)}\right.$ \\
\hline 1994 & $-3,3$ \\
1995 & 4,3 \\
1996 & 0,2 \\
1997 & 1,8 \\
1998 & 2,4 \\
1999 & 0,8 \\
2000 & $-1,4$ \\
2001 & $-2,0$ \\
2002 & $-1,0$ \\
2003 & 2,4 \\
2004 & 1,0 \\
2005 & 2,9 \\
2006 & 2,8 \\
2007 & 2,6 \\
2008 & 1,8 \\
2009 & 0,6 \\
Med & $\mathbf{1 , 0}$ \\
\hline
\end{tabular}

A análise dos dados mensais da Tabela 35 indica que janeiro é o mês mais quente da série, com temperatura média mínima de $14,1^{\circ} \mathrm{C}$, máxima de $17^{\circ} \mathrm{C}$ e mínima de $11^{\circ} \mathrm{C}$, apresentando um desvio padrão de $2,1^{\circ} \mathrm{C}$ e coeficiente de variação de $14,5 \%$. Os meses de junho e julho, com valores bem próximo, mostraram-se os mais frios, com temperaturas médias mínimas de $3^{\circ} \mathrm{C}$ e $2,6^{\circ} \mathrm{C}$, máximas de $6,4^{\circ} \mathrm{C}$ e $6,7^{\circ} \mathrm{C}$ e mínimas de $-2^{\circ} \mathrm{C}$ e $-3,3^{\circ} \mathrm{C}$, respectivamente. Os desvios padrão tiveram valores iguais a $2,2^{\circ} \mathrm{C}$ e $2,7^{\circ} \mathrm{C}$, com coeficientes de variação de $73,5 \%$ e $103 \%$, respectivamente, indicando uma grande variabilidade térmica para esses dois meses. A amplitude térmica da temperatura média mínima é igual a $14,3{ }^{\circ} \mathrm{C}$ $\left[11^{\circ} \mathrm{C}-\left(-3,3^{\circ} \mathrm{C}\right)\right]$, indicando grande variabilidade climática dessa variável entre os meses de janeiro e julho para a série estudada. 
Tabela 35 - Valores da temperatura mínima, desvio padrão (DP) e coeficiente de variação (CV) da temperatura média anual e mensal no município de São Carlos/SP para os anos de 1994 a 2009.

\begin{tabular}{cccccc}
\hline Anual/mensal & $\begin{array}{c}\text { Méd Min } \\
\left({ }^{\mathbf{0}} \mathbf{C}\right)\end{array}$ & $\begin{array}{c}\text { DP } \\
\left({ }^{\mathbf{0}} \mathbf{C}\right)\end{array}$ & $\begin{array}{c}\mathbf{C V} \\
(\mathbf{\%})\end{array}$ & $\begin{array}{c}\text { MaxMin } \\
\left({ }^{\mathbf{0}} \mathbf{C}\right)\end{array}$ & $\begin{array}{c}\text { MinMin } \\
\left({ }^{\mathbf{0}} \mathbf{C}\right)\end{array}$ \\
\hline jan & 14,1 & 2,1 & 14,5 & 17 & 11 \\
fev & 13,9 & 1,6 & 11,7 & 16,2 & 10,5 \\
mar & 13,1 & 1,6 & 12,2 & 15,4 & 10,4 \\
abr & 7,9 & 3,3 & 40,9 & 11,8 & 0,8 \\
mai & 5,3 & 1,9 & 36,5 & 8,8 & 1 \\
jun & 3,0 & 2,2 & 73,5 & 6,4 & -2 \\
jul & 2,6 & 2,7 & 103 & 6,7 & $-3,3$ \\
ago & 4,7 & 2,2 & 47,4 & 9,1 & 1 \\
set & 6,5 & 2,4 & 37,2 & 10,5 & 1,5 \\
out & 8,9 & 1,7 & 19,8 & 12,6 & 6,6 \\
nov & 10,1 & 1,5 & 15,5 & 13,1 & 7,6 \\
dez & 12,6 & 2,2 & 17,2 & 15,7 & 10,1 \\
Anual & $\mathbf{8 , 5}$ & $\mathbf{0 , 7}$ & $\mathbf{8 , 7}$ & $\mathbf{9 , 6}$ & $\mathbf{7 , 1 9}$
\end{tabular}

O Gráfico 42 mostra que para os dois primeiros anos da série ocorreu uma grande variabilidade com temperatura mínima variando de $-3,3^{\circ} \mathrm{C}$ até $4,3^{\circ} \mathrm{C}$. Os anos seguintes apresentaram variabilidade um pouco menos acentuada, com as temperaturas oscilando em torno da média, com valores aproximadamente $1,2^{\circ} \mathrm{C}$ para mais e para menos. Os últimos cinco anos da série apresentaram valores bem próximos da média, com variabilidade muito baixa.

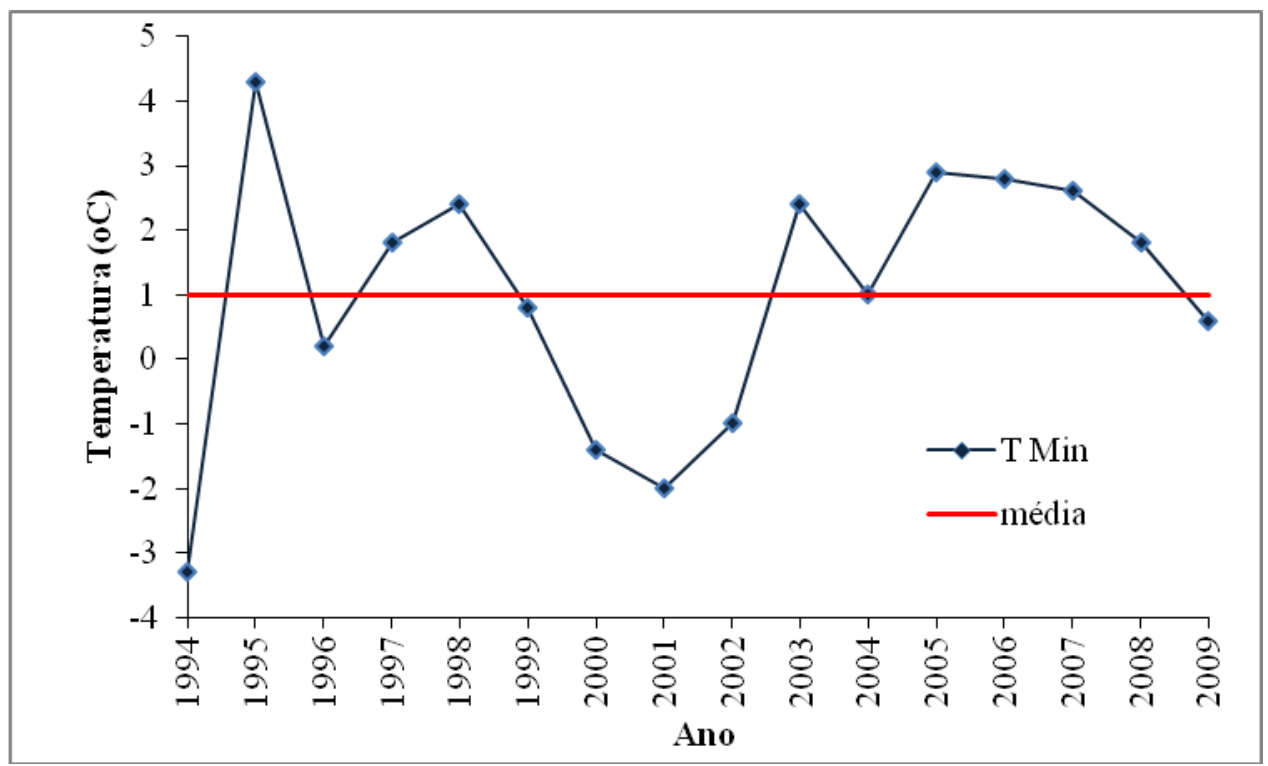

Gráfico 42 - Temperatura mínima anual no município de São Carlos/SP para os anos de 1994 a 2009. 


\subsubsection{4 - Temperatura média máxima}

Sobre o comportamento anual da temperatura média máxima pode-se verificar a inexistência de uma variabilidade estatística significativa para o período 1994-2009. De acordo com a Tabela 36 e o Gráfico 43, a média para o período é de $27,9^{\circ} \mathrm{C}$, com máxima de $28,9^{\circ} \mathrm{C}$, em 2007 , e a mínima de $27,3^{\circ} \mathrm{C}$, em 1996 , indicando uma estabilidade térmica para essa variável, com os valores oscilando em torno de uma situação média.

Tabela 36 - Valores da temperatura média máxima anual no município de São Carlos/SP para a série temporal de 1994 a 2009.

\begin{tabular}{cc}
\hline Ano & Tmédmax $\left({ }^{\mathbf{0}} \mathbf{C}\right)$ \\
\hline 1994 & 28,5 \\
1995 & 28,0 \\
1996 & 27,3 \\
1997 & 27,6 \\
1998 & 27,4 \\
1999 & 27,4 \\
2000 & 27,7 \\
2001 & 27,9 \\
2002 & 28,8 \\
2003 & 28,2 \\
2004 & 27,4 \\
2005 & 27.9 \\
2006 & 28,2 \\
2007 & 28,9 \\
2008 & 27,9 \\
2009 & 27,7 \\
Med & $\mathbf{2 7 , 9}$ \\
\hline
\end{tabular}




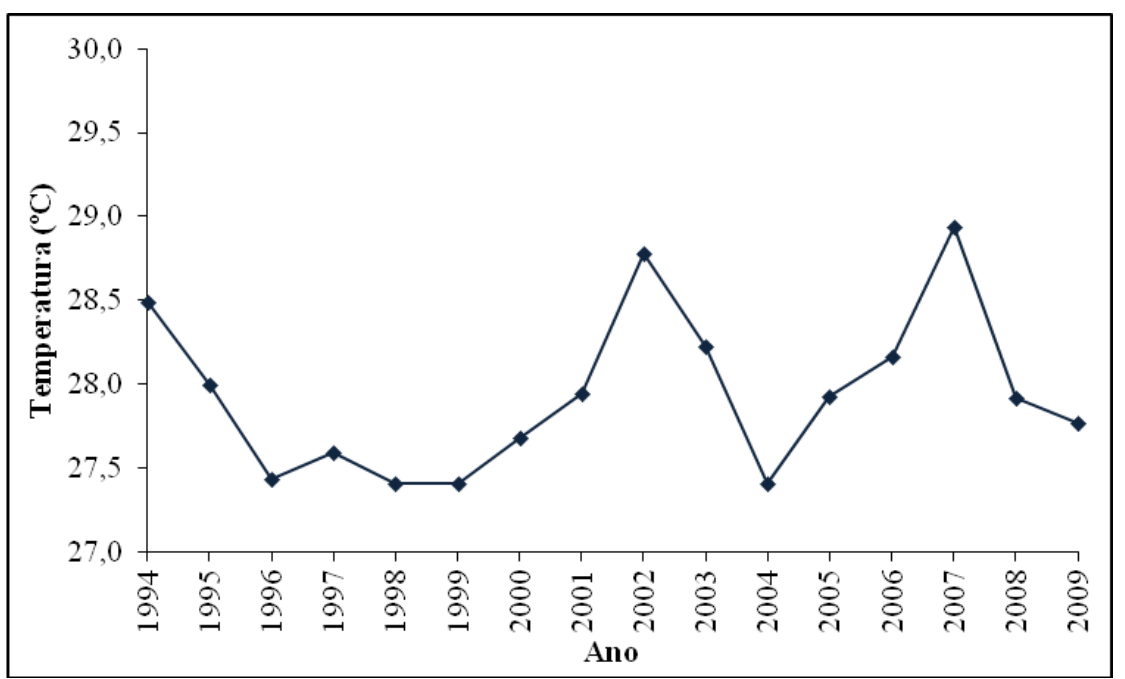

Gráfico 43 - Temperatura média máxima anual no município de São Carlos/SP para os anos de 1994 a 2009.

\subsubsection{5 - Temperatura média mínima}

Durante o período a temperatura média mínima oscilou entre os valores de $12{ }^{\circ} \mathrm{C} \mathrm{em}$ 1999 e $14,6^{\circ} \mathrm{C}$ em 2007 , com uma média de $13,4^{\circ} \mathrm{C}$ para o período, sem variabilidade significativa para a série, conforme Tabela 37 e Gráfico 44.

Tabela 37 - Valores da temperatura média mínima anual no município de São Carlos/SP para a série temporal de 1994 a 2009.

\begin{tabular}{cc}
\hline Ano & Tmedmin $\left({ }^{\mathbf{0}} \mathbf{)}\right.$ \\
\hline 1994 & 13,9 \\
1995 & 13,4 \\
1996 & 13,6 \\
1997 & 13,8 \\
1998 & 13,0 \\
1999 & 12,0 \\
2000 & 13,3 \\
2001 & 13,2 \\
2002 & 14,2 \\
2003 & 14,0 \\
2004 & 12,7 \\
2005 & 12,7 \\
2006 & 13,7 \\
2007 & 14,6 \\
2008 & 13,2 \\
2009 & 13,5 \\
Med & $\mathbf{1 3 , 4}$ \\
\hline
\end{tabular}




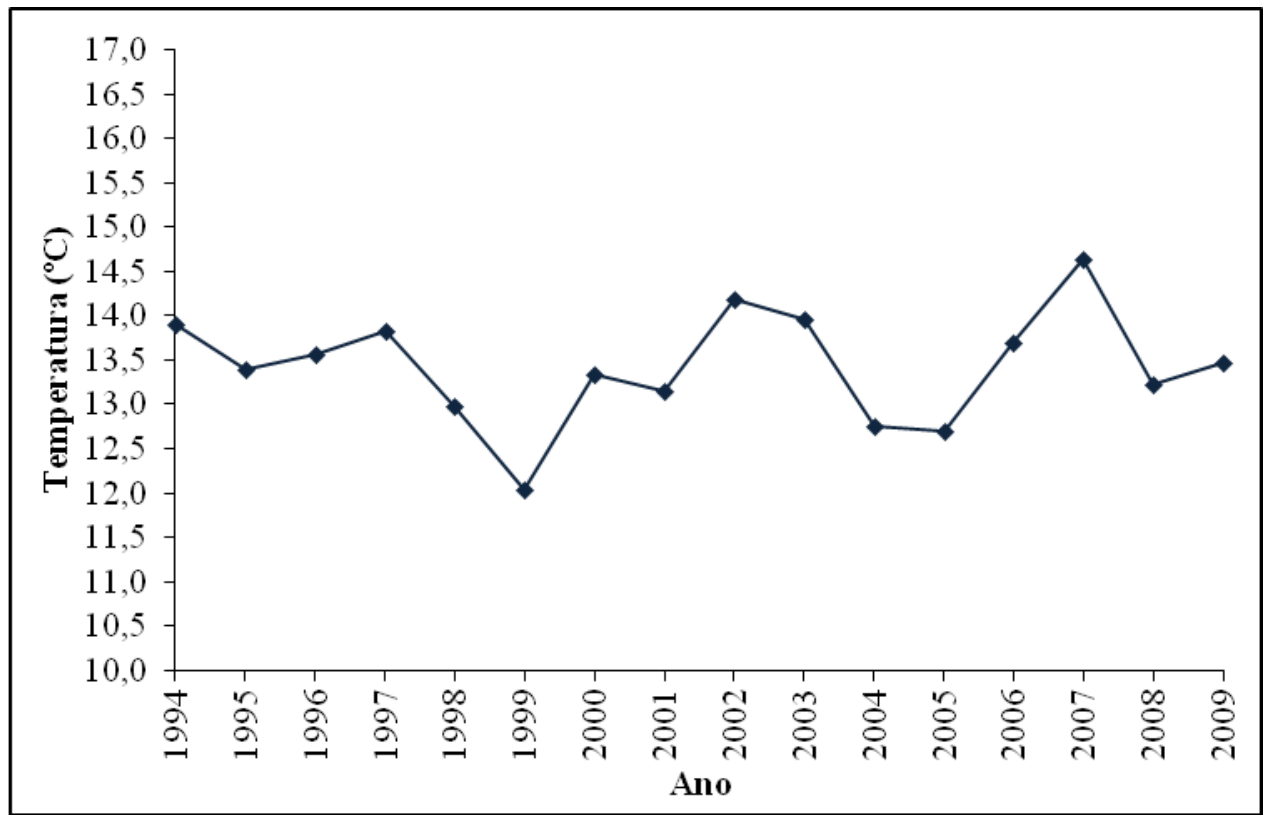

Gráfico 44 - Temperatura média mínima anual no município de São Carlos/SP para os anos de 1994 a 2009.

\subsection{2 - Análise da tendência para as temperaturas médias, máximas, mínimas, média} máxima e média mínima: retas de regressão.

A temperatura média para o período apresenta uma tendência decrescente, correspondente a uma diminuição de $0,0494^{\circ} \mathrm{C} /$ ano ao longo dos dezesseis anos. O coeficiente de determinação é igual a 0,0617, explicando que a reta da temperatura média em relação ao tempo, se ajusta em apenas 6,17\%, conforme Gráfico 45, que também mostra a reta de tendência apontando para um decréscimo de aproximadamente $0,79^{\circ} \mathrm{C}$ na temperatura média anual durante o período, determinando a ausência de tendência. 


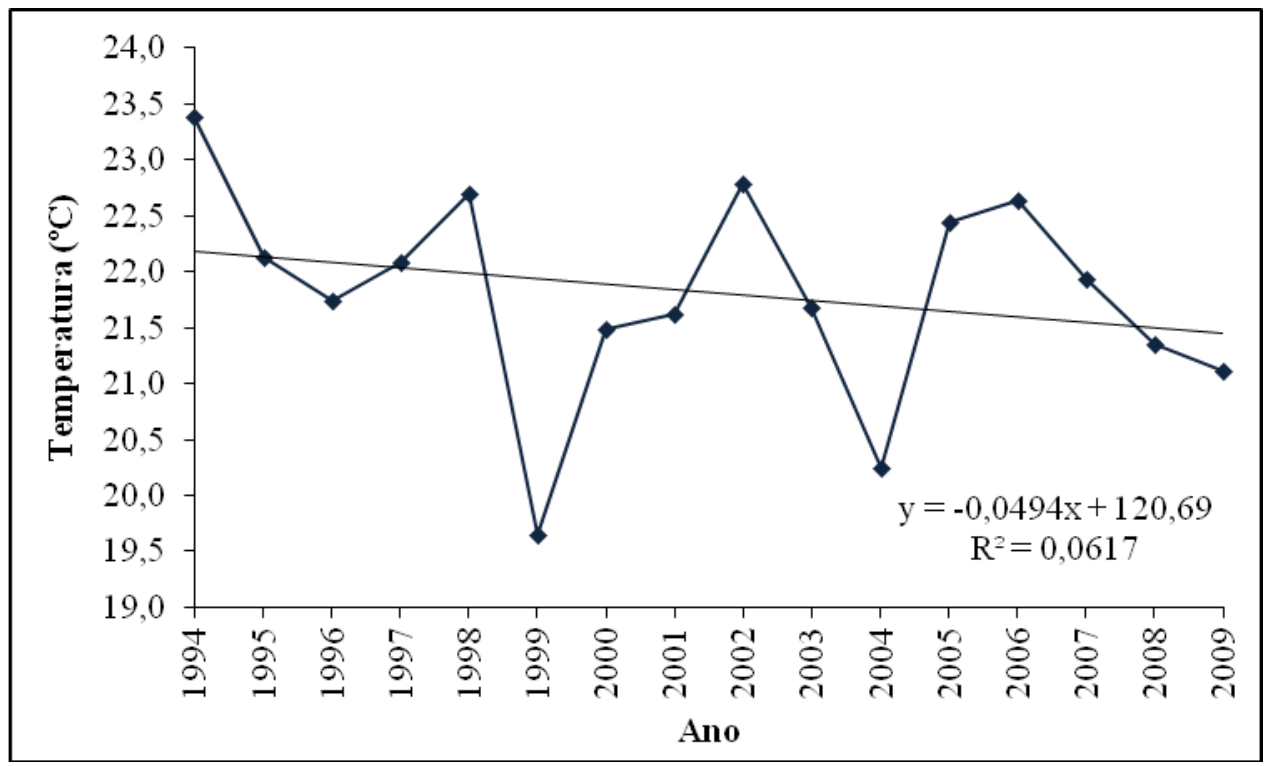

Gráfico 45 - Reta de regressão para a temperatura média anual no município de São Carlos/SP para os anos de 1994 a 2009.

A análise do Gráfico 46 indica que a reta ajustada para o período mostrou uma tendência de acréscimo, evidenciada pelo coeficiente angular, e uma propensão à elevação da temperatura máxima à razão de $0,1369^{\circ} \mathrm{C} / \mathrm{ano}$, totalizando um aumento de aproximadamente $2^{\circ} \mathrm{C}$ para os dezesseis anos de observação da série considerada, caracterizando-se como tendência significativa. Também a reta não se ajustou bem aos dados, fato demonstrado pelo coeficiente de determinação $\mathrm{R}^{2}$ igual a 0,1479 .

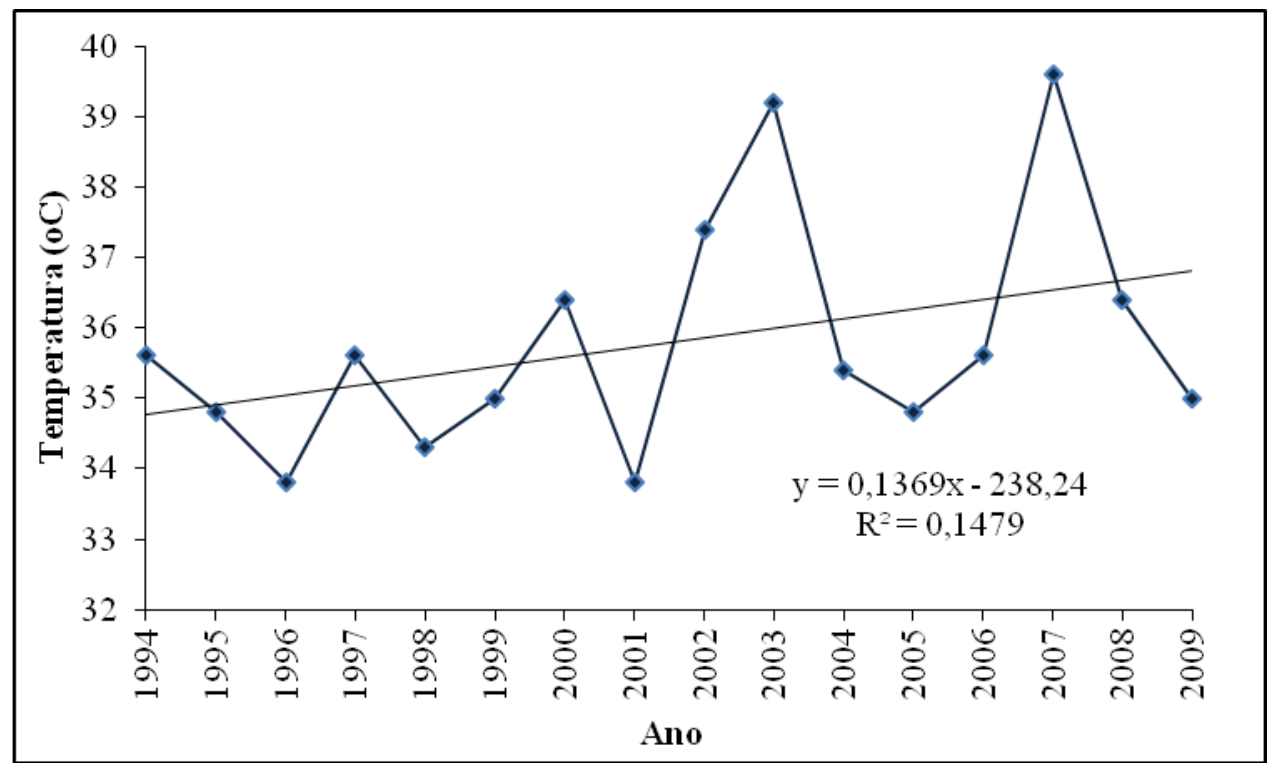

Gráfico 46 - Reta de regressão para a temperatura máxima anual no município de São Carlos/SP para os anos de 1994 a 2009. 
O Gráfico 47, relativo à temperatura mínima, mostra que ocorre uma tendência de aumento à razão de $0,1151^{\circ} \mathrm{C} / \mathrm{ano}$, com $\mathrm{R}^{2}=0,0709$, indicando que a reta não se ajusta aos dados da série. O coeficiente angular da reta determina que, para os dezesseis anos da série, a temperatura mínima sofreria um acréscimo de $1,84^{\circ} \mathrm{C}$, valor indicativo de tendência significativa para essa variável.

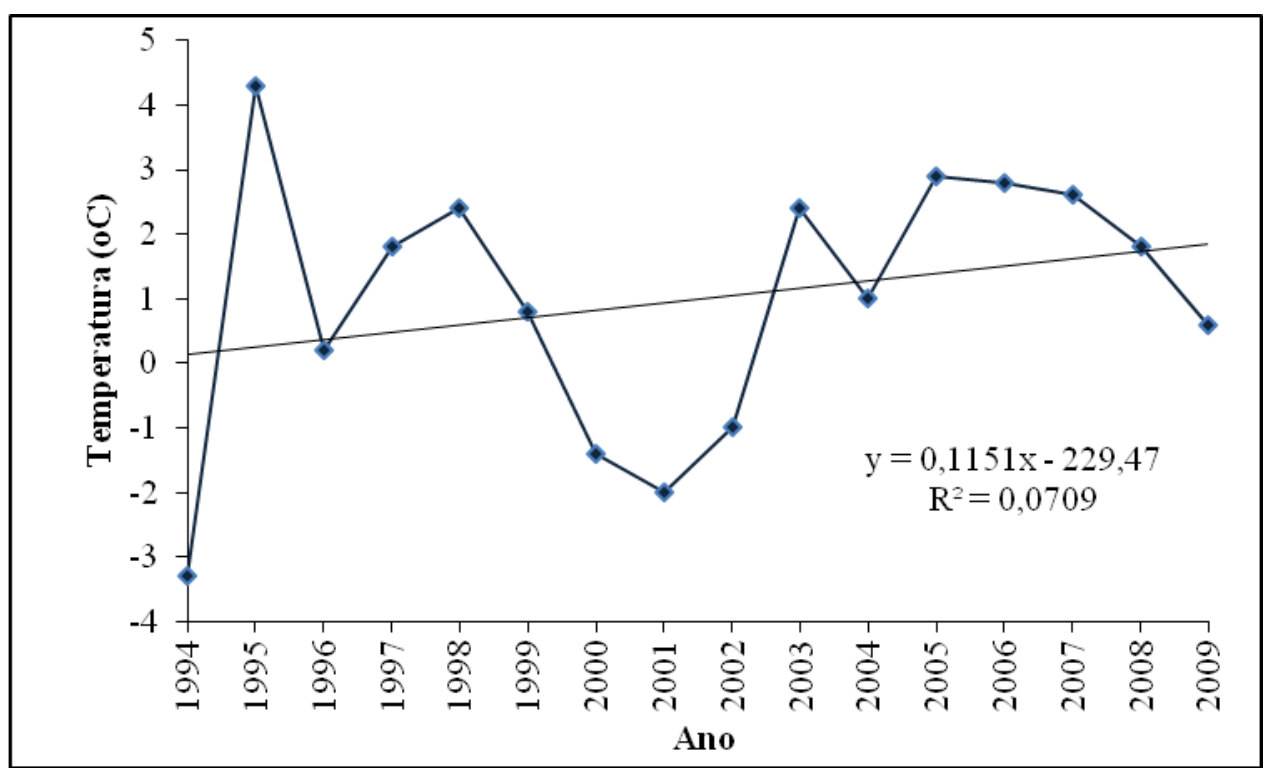

Gráfico 47 - Reta de regressão para a temperatura mínima anual no município de São Carlos/SP para os anos de 1994 a 2009.

O Gráfico 48 mostra que a temperatura média máxima aponta para uma tendência de crescimento, à taxa de $0,0236^{\circ} \mathrm{C}$ ao ano, contabilizando $0,37^{\circ} \mathrm{C}$ ao longo da série de dezesseis anos, para um coeficiente de determinação da reta ajustada aos dados, $\mathrm{R}^{2}=0,0549$, indicando quase nenhuma variação da temperatura média máxima associada à variação temporal. $\mathrm{O}$ valor do acréscimo total da temperatura e a inclinação da reta evidenciam que tendência é pouco significativa, podendo ser considerada como estabilidade. É possível afirmar, então, que, pela medida estatística da reta de regressão, essa variável não apresenta tendência significativa. 


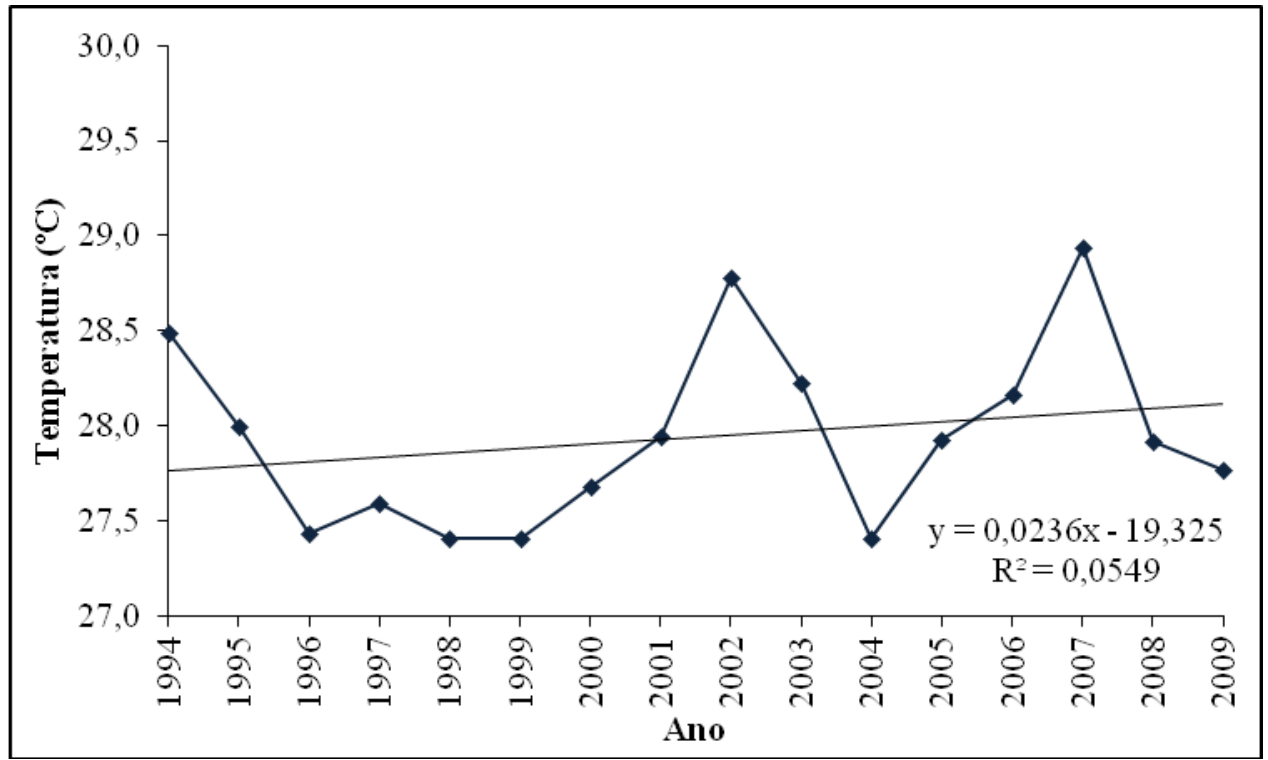

Gráfico 48 - Reta de regressão para a temperatura média máxima anual no município de São Carlos/SP para os anos de 1994 a 2009.

A reta de regressão do Gráfico 49 aponta para uma mínima inclinação positiva nos valores da temperatura média mínima, à taxa de $0,0092^{\circ} \mathrm{C} / \mathrm{ano}$, totalizando $0,14^{\circ} \mathrm{C}$ para a série toda, mostrando tendência dessa variável não significativa e apontando para estabilidade da mesma. Com o valor de $\mathrm{R}^{2}=0,0047$ fica evidente que a reta de regressão não foi ajustada aos dados em razão da ausência de uma propensão manifestada pela temperatura média mínima.

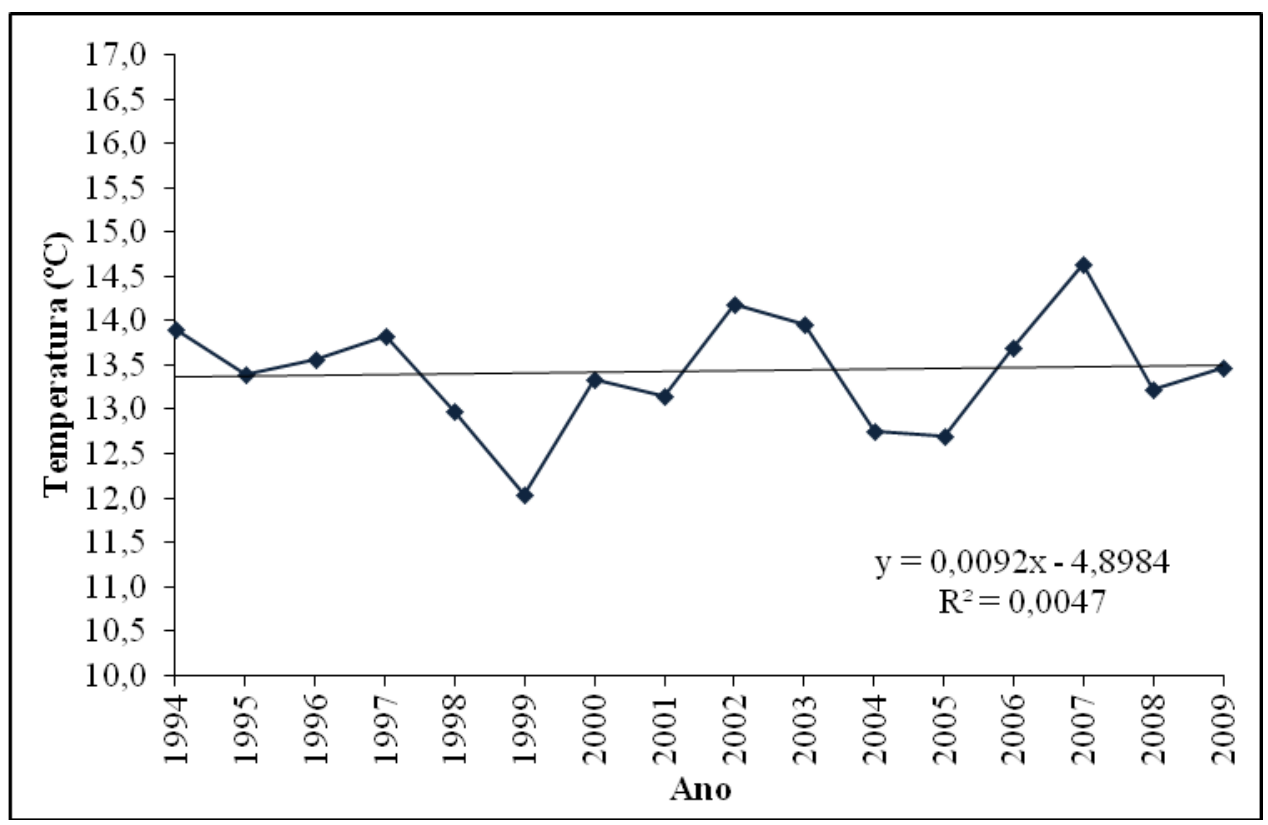

Gráfico 49 - Reta de regressão para a temperatura média mínima anual no município de São Carlos/SP para os anos de 1994 a 2009. 


\subsection{3 - Análise da variabilidade para a pluviosidade}

Para a série temporal estudada (1994 a 2009) registrou-se o total anual médio de 1481,9 mm, sendo 1995 o ano mais chuvoso (1790,4 mm), e 1994, o menos chuvoso (1180,0 mm), dois valores extremos de um ano para o outro, mostrando uma variabilidade acentuada nesse biênio, conforme se observa na Tabela 38 .

Tabela 38 - Valores da pluviosidade total anual no município de São Carlos/SP para a série temporal de 1994 a 2009.

\begin{tabular}{cc}
\hline Ano & Pluviosidade (mm) \\
\hline 1994 & 1180,0 \\
1995 & 1790,4 \\
1996 & 1640,5 \\
1997 & 1383,2 \\
1998 & 1686,1 \\
1999 & 1407,1 \\
2000 & 1503,6 \\
2001 & 1644,4 \\
2002 & 1416,9 \\
2003 & 1325,3 \\
2004 & 1617,9 \\
2005 & 1424,9 \\
2006 & 1396,1 \\
2007 & 1502,7 \\
2008 & 1320,4 \\
2009 & 1472,2 \\
Med & $\mathbf{1 4 8 1 , 9}$ \\
\hline
\end{tabular}

A Tabela 39 mostra o comportamento mensal da pluviosidade e a análise do período escolhido evidencia que sua distribuição não é homogênea ao longo do ano. As maiores pluviosidades ocorreram em novembro, dezembro, janeiro e fevereiro, com precipitação média de 232,9 mm para esses meses, com a máxima de 326,9 $\mathrm{mm}$ em janeiro. Verifica-se também a ocorrência de quatro meses (junho, julho, agosto e setembro) sem a incidência de chuvas em alguns anos ao longo da série. A estações com menor precipitação (seca) são outono e inverno, abrangendo os meses de abril a setembro, em decorrência do clima tropical da região.

Os meses da estação menos chuvosa, em geral, apresentam pluviosidades médias mensais abaixo de $60 \mathrm{~mm}$. Já o período compreendido entre o primeiro trimestre (janeiro, 
fevereiro e março) e o último (outubro, novembro e dezembro), apresenta valores médios de pluviosidade acima de $100 \mathrm{~mm}$. O trimestre menos chuvoso constituído pelos meses de junho, julho e agosto apresentaram pluviosidade média abaixo dos $40 \mathrm{~mm}$.

Maio, junho, julho, agosto e setembro registraram valores da pluviosidade mínima igual a zero para alguns anos do período, que teve pluviosidade média anual foi de 1481,9 $\mathrm{mm}$, sendo verificado um desvio padrão de $159,1 \mathrm{~mm}$ e coeficiente de variação de $10 \%$, conforme a Tabela 39.

Tabela 39 - Valores da média, desvio padrão (DP) e coeficiente de variação (CV) da pluviosidade média anual e mensal no município de São Carlos/SP para os anos de 1994 a 2009.

\begin{tabular}{cccccc}
\hline Anual/mensal & $\begin{array}{c}\text { Média } \\
(\mathbf{m m})\end{array}$ & $\begin{array}{c}\text { DP } \\
(\mathbf{m m})\end{array}$ & $\begin{array}{c}\mathbf{C V} \\
(\mathbf{\%})\end{array}$ & $\begin{array}{c}\text { Max } \\
(\mathbf{m m})\end{array}$ & $\begin{array}{c}\text { Min } \\
(\mathbf{m m})\end{array}$ \\
\hline jan & 326,9 & 112,5 & 34 & 542,3 & 174,8 \\
fev & 219,5 & 110,4 & 50 & 523,3 & 69 \\
mar & 149,7 & 77,2 & 51 & 347,6 & 64 \\
abr & 65,1 & 40,0 & 61 & 140,3 & 6 \\
mai & 59,3 & 34,9 & 58 & 134,9 & 5,6 \\
jun & 35,4 & 39,7 & 112 & 168 & 0 \\
jul & 29,1 & 40,7 & 140 & 161,4 & 0 \\
ago & 36,2 & 45,6 & 126 & 170,8 & 0 \\
set & 62,1 & 45,9 & 73 & 152,9 & 0 \\
out & 113,0 & 41,8 & 37 & 219,6 & 38,8 \\
nov & 162,3 & 74,5 & 45 & 351,7 & 34,1 \\
dez & 223,1 & 70,4 & 31 & 361,7 & 125,9 \\
Anual & $\mathbf{1 4 8 1 , 9}$ & $\mathbf{1 5 9 , 1}$ & $\mathbf{1 0}$ & $\mathbf{1 7 9 0 , 4}$ & $\mathbf{1 1 8 0}$ \\
\hline
\end{tabular}

O Gráfico 50 mostra a distribuição temporal da pluviosidade total anual para o período estudado: constata-se que a pluviosidade anual apresentou-se bem distribuída ao longo da série, chamando a atenção para o valor máximo registrado em 1995 e o mínimo em 1994. A pluviosidade anual média nesse período é de $1481,9 \mathrm{~mm}$, valor um pouco acima da normal climatológica de $1352 \mathrm{~mm}$, determinada pelo INMET. Para os dados referentes aos dezesseis anos de observação, apenas cinco anos registraram pluviosidade acima da média e os onze anos restantes, abaixo da média, indicativo de variabilidade bastante acentuada. 


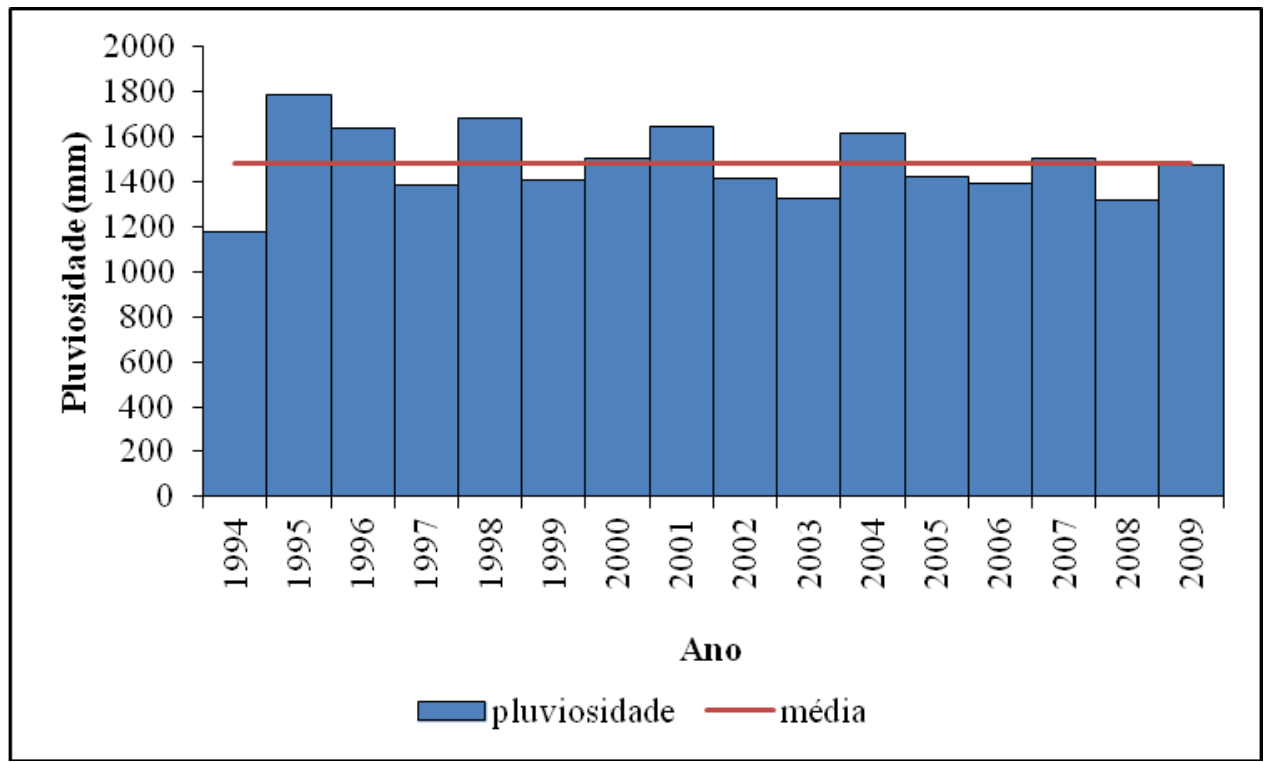

Gráfico 50 - Pluviosidade total anual de São Carlos/SP de 1994 a 2009

A curva do Gráfico 51 mostra, também, a variabilidade da chuva em intervalos menores, apresentando períodos de dispersões mais ou menos acentuadas. O polinômio de grau cinco ajustado à série de dados anuais aponta para a grande variabilidade da pluviosidade, que, ao longo da série apresentou valores oscilando entre 1100 e $1700 \mathrm{~mm}$, com exceção do ano de 1995, com valor acima de $1700 \mathrm{~mm}$.

A análise por períodos mais curtos ao longo da série evidencia que a curva indica a maior variabilidade crescente entre 1994 e 1995, decrescendo acentuadamente de 1996 a 2002. Entre 2002 e 2006 volta a ter um comportamento levemente crescente e, depois, decresce até 2009, evidenciando claramente a variabilidade do regime de chuvas para a localidade. 


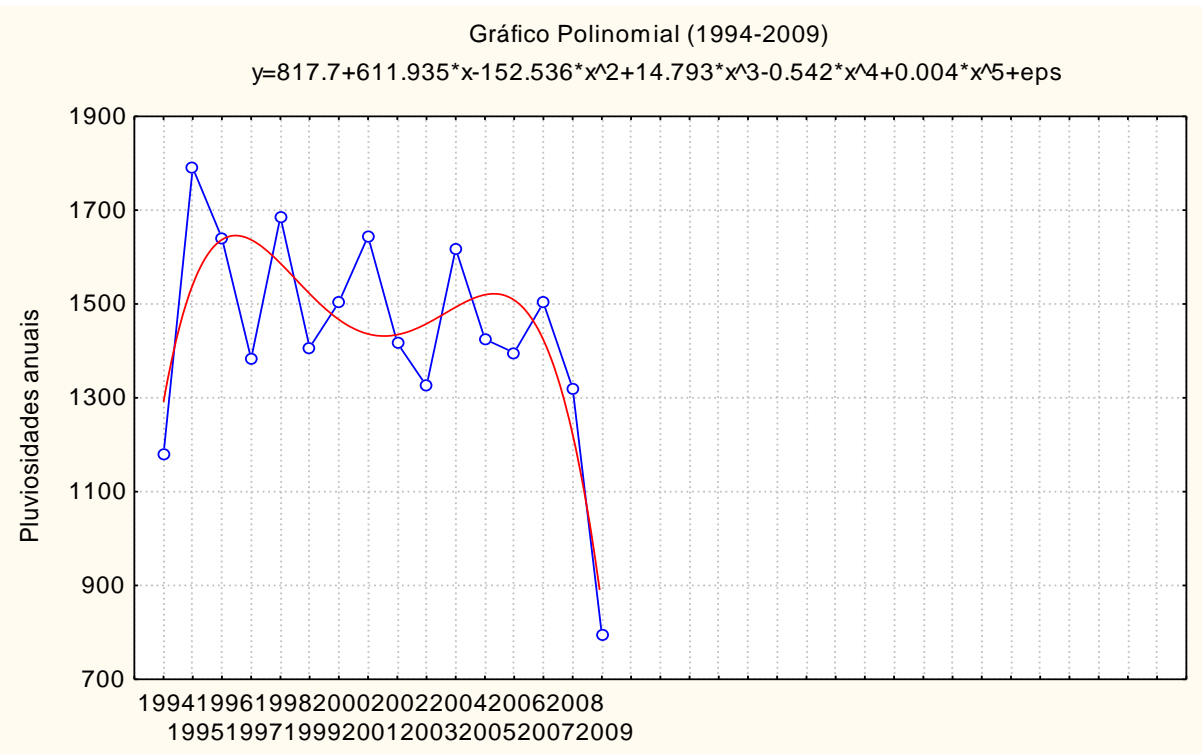

Gráfico 51 - Pluviosidade total anual de São Carlos/SP de 1994 a 2009, curva de regressão polinomial de grau 5.

\subsection{4 - Análise da tendência para a pluviosidade: reta de regressão}

O Gráfico 52 mostra a reta de tendência para a pluviosidade. O coeficiente angular da reta de regressão determina um decréscimo de 6,858 mm/ano de chuva ao longo da série, perfazendo um total de $109,7 \mathrm{~mm}$, o que pode ser considerado como uma diminuição pouco acentuada nos valores da pluviosidade no período considerado.

A análise dos dados indica, então, uma tendência de diminuição nos valores da precipitação na localidade. $O$ valor do coeficiente de determinação $\left(R^{2}=0,042\right)$ mostra também que a reta de regressão não está bem ajustada aos dados, portanto quase nenhuma variação da pluviosidade esteve bem associada ao tempo. A tendência observada pode ser atribuída à variabilidade natural do clima. 


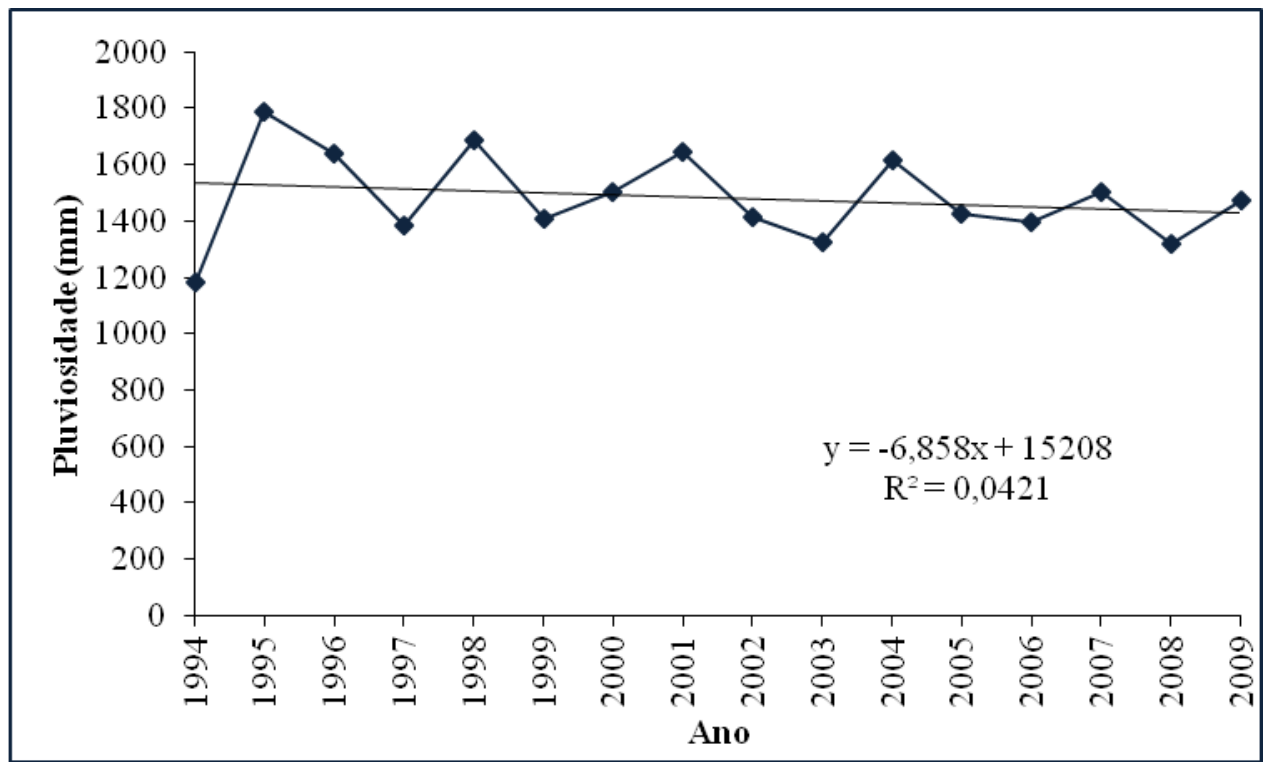

Gráfico 52 - Tendência da pluviosidade total anual no município de São Carlos/SP no período de 1994 a 2009 - reta de regressão.

\subsection{5 - Análise da tendência para a temperatura e pluviosidade: teste de Mann-Kendall e curvatura de Sen}

5.4.5.1 - Medidas estatísticas das temperaturas máximas, médias máximas, mínimas, médias mínimas, médias e pluviosidades em São Carlos no período de 1994-2009.

Os aplicativos estatísticos Statistica e BioEstat forneceram resultados apresentados abaixo para a cidade de São Carlos no período de 1994-2009.

Tabela 40 - Medidas estatísticas de temperatura máxima, temperatura média máxima, temperatura mínima, temperatura média mínima e pluviosidade para São Carlos/SP.

\begin{tabular}{|l|c|c|c|c|c|}
\hline \multirow{4}{*}{ Estatística } & \multicolumn{5}{|c|}{ Variáveis Meteorológicas } \\
\cline { 2 - 6 } & $\begin{array}{c}\text { temperatura } \\
\text { máxima } \\
\left({ }^{\circ} \mathrm{C}\right)\end{array}$ & $\begin{array}{c}\text { Temperatura } \\
\text { média máxima } \\
\left({ }^{\circ} \mathrm{C}\right)\end{array}$ & $\begin{array}{c}\text { Temperatura } \\
\text { Mínima } \\
\left({ }^{\circ} \mathrm{C}\right)\end{array}$ & $\begin{array}{c}\text { Temperatura } \\
\text { média mínima } \\
\left({ }^{\circ} \mathrm{C}\right)\end{array}$ & Pluviosidade(mm) \\
\hline Mínimo & 31,62 & 27,40 & 7,19 & 12,03 & 794,80 \\
Máximo & 33,87 & 28,93 & 9,83 & 14,63 & 1790,40 \\
M. A. & 32,33 & 27,94 & 8,57 & 13,47 & 1439,64 \\
D. P. & 0,5529 & 0,4790 & 0,7938 & 0,6670 & 234,27 \\
CV (\%) & 1,71 & 1,71 & 9,26 & 4,95 & 16,27 \\
Assim. & 0,7458 & 0,7427 & $-0,3618$ & $-0,3697$ & $-1,23$ \\
Curtose & $-0,6254$ & $-0,1812$ & $-0,7144$ & 0,1054 & 3,9419 \\
\hline
\end{tabular}

Onde: M. A. = Média Aritmética; D. P. = desvio padrão; CV = coeficiente de variação; Assim. $=$ coeficiente de assimetria; curtose $=$ Coeficiente de curtose 
Pode-se observar na Tabela 40 que há certa proximidade numérica entre as medidas estatísticas Mínimo, Máximo e M.A. para as colunas da temperatura máxima e média máxima e para a mínima e média mínima, não ocorrendo o mesmo para a pluviosidade. O comportamento das medidas de variabilidade - desvio padrão (DP) e coeficiente de variação $\mathrm{CV}(\%)$ - são baixos para as séries, indicando pouca variabilidade entre os dados. Em relação à assimetria, todas as séries são classificadas como assimétricas. As temperaturas máximas e média máximas do período são assimétricas à direita, pois apresentam o coeficiente do momento de assimetria positivo, enquanto as séries para as temperaturas mínimas, médias mínimas e pluviosidades são classificadas como assimétricas à esquerda ou negativa. Em relação à curtose, todas as colunas referentes às temperaturas são classificadas como platicúrticas (Coeficiente de Curtose<3), e a coluna da pluviosidade, como leptocúrtica (Coeficiente de Curtose>3).

\subsubsection{2 - Análises das tendências e das estimativas}

A seguir são apresentados resultados das análises das variáveis meteorológicas de São Carlos, no período de 1994-2009, a partir dos testes estatísticos de Mann-Kendall (MK) e Curvatura de Sen (CS), considerando o nível de confiança de $95 \%$ ou $\alpha=5 \%$.

Tabela 41 - Análise estatística das variáveis meteorológicas $(\alpha=5 \%)$ para São Carlos/SP.

\begin{tabular}{|l|c|c|c|c|c|c|}
\hline \multirow{2}{*}{ Estatística } & \multicolumn{6}{|c|}{ Variáveis Meteorológicas } \\
\cline { 2 - 7 } & $\begin{array}{c}\text { Temperatura } \\
\text { Máxima } \\
\left({ }^{\circ} \mathrm{C}\right)\end{array}$ & $\begin{array}{c}\text { Temperatura } \\
\text { Média Máxima } \\
\left({ }^{\circ} \mathrm{C}\right)\end{array}$ & $\begin{array}{c}\text { Temperatura } \\
\text { Mínima } \\
\left({ }^{\circ} \mathrm{C}\right)\end{array}$ & $\begin{array}{c}\text { Temperatura } \\
\text { Médias mínima } \\
\left({ }^{\circ} \mathrm{C}\right)\end{array}$ & $\begin{array}{c}\text { Temperatura } \\
\text { Média } \\
\left({ }^{\circ} \mathrm{C}\right)\end{array}$ & $\begin{array}{c}\text { Pluviosidade } \\
(\mathrm{mm})\end{array}$ \\
\hline Escore Z & 0,8112 & 0,6310 & 0,5853 & 0,4052 & $-1,2181$ & 1,5758 \\
MK & 0,1583 & 0,1250 & 0,1167 & 0,0833 & $-0,2333$ & 0,3000 \\
CS & 0,0388 & 0,0300 & 0,0274 & 0,0222 & $-0,0519$ & 21,6750 \\
Prob. $(p)$ & 0,4172 & 0,5281 & 0,5584 & 0,6853 & 0,22232 & 0,1151 \\
\hline
\end{tabular}

A tabela 41 permite verificar que, com exceção da coluna das temperaturas médias, com tendência negativa, com Mann-Kendall decrescente, pois $\mathrm{Z}<0$. Para os resultados de todas as outras colunas há tendências positivas, com Mann-Kendall, crescente, pois Z $>0$, mas insignificantes, pois $p>\alpha$. Os crescimentos dessas variáveis (temperaturas anuais) são 
aproximadamente de $0,0388^{\circ} \mathrm{C}, 0,0300^{\circ} \mathrm{C}, 0,0274^{\circ} \mathrm{C}$ e $0,0222^{\circ} \mathrm{C}$, respectivamente, pela Curvatura de Sen. Para a pluviosidade observa-se um decréscimo de 21,6750 mm/ano. É preciso observar, também, que para as colunas das temperaturas máximas, médias e pluviosidades as tendências são mais acentuadas, pois apresentam valores de $\mathrm{Z}$ mais próximos de 1.

A comparação dos resultados por Mann-Kendall e Sen com a reta de regressão do Gráfico 45 para as temperaturas médias, evidencia que, pelos dois métodos, houve uma tendência de decréscimo, cujas magnitudes são iguais a $0,0519^{\circ} \mathrm{C} / \mathrm{ano}$, pela curvatura de Sen (Tabela 41), e $0,0494^{\circ} \mathrm{C} / \mathrm{ano}$, pelo coeficiente angular, ou seja, resultados praticamente iguais. Embora se tenha comprovado que os dois métodos forneceram resultados semelhantes, a eficiência do método MK e Sen é mais confiável.

Verifica-se também que os resultados obtidos para a temperatura máxima indicam uma semelhança entre os dois métodos, pois o coeficiente angular da reta de regressão do Gráfico 46 indica que a tendência é de crescimento à razão de $0,1369^{\circ} \mathrm{C} /$ ano e por $\mathrm{MK}$ e Sen, a tendência é também positiva de acréscimo na ordem de $0,0388^{\circ} \mathrm{C} / \mathrm{ano}$, resultados diferentes quanto à magnitude, mas semelhantes quanto à tendência.

Para a pluviosidade anual, embora insignificante por MK, ocorreu uma tendência mais acentuada, podendo ser constatado um decréscimo de $21,675 \mathrm{~mm} /$ ano, observando-se a medida determinada pela curvatura de Sen, no total de $346,8 \mathrm{~mm}$ para a série toda. A comparação deste resultado com o obtido no Gráfico 52 (reta de regressão), mostra, novamente, a coerência quanto à tendência no declínio da pluviosidade, embora tenha ocorrido uma diferença nas magnitudes, pois o coeficiente angular determinou uma taxa de decréscimo de 4,1597 mm/ano, resultando no total de 67,2 $\mathrm{mm}$, aproximadamente. 
5.5 - Análise estatística dos dados de temperatura e pluviosidade da série temporal de 1994 a 2009 para São Simão/SP.

\subsection{1 - Análise da variabilidade da temperatura}

\subsubsection{1 - Temperatura média}

De acordo com a Tabela 42, a análise do comportamento anual da temperatura média durante a série temporal considerada mostra que a temperatura média anual do período é de $22,2^{\circ} \mathrm{C}$, com a média mais elevada de $23,2^{\circ} \mathrm{C}$, registrada em 2002 e a média mais baixa, de $20,6^{\circ} \mathrm{C}$, em 2001 , com pequena amplitude térmica de $2,6^{\circ} \mathrm{C}$, indicando baixa variabilidade, pois os valores encontrados para os outros anos da série oscilam em torno da situação média.

Tabela 42 - Valores da temperatura média anual no município de São Simão/SP para a série temporal de 1994 a 2009.

\begin{tabular}{cc}
\hline Ano & Tméd $\left({ }^{\mathbf{C}}\right)$ \\
\hline 1994 & 21,8 \\
1995 & 22,0 \\
1996 & 21,7 \\
1997 & 22,0 \\
1998 & 22,4 \\
1999 & 22,2 \\
2000 & 22,3 \\
2001 & 20,6 \\
2002 & 23,2 \\
2003 & 22,2 \\
2004 & 21,9 \\
2005 & 22,5 \\
2006 & 22,4 \\
2007 & 22,8 \\
2008 & 22,1 \\
2009 & 22,2 \\
Med & $\mathbf{2 2 , 2}$ \\
\hline
\end{tabular}

Em relação ao comportamento mensal da temperatura média, a Tabela 43, mostra que o primeiro e o último trimestres do ano representam os períodos com temperaturas mais elevadas, sendo janeiro o mês mais quente do ano, com média mensal de $24,4^{\circ} \mathrm{C}$, desvio padrão de $0,4^{\circ} \mathrm{C}$, coeficiente de variação de $2 \%$, temperatura média máxima igual a $25,3^{\circ} \mathrm{C}$ e 
temperatura média mínima de $23,6^{\circ} \mathrm{C}$. Os meses de maio, junho, julho e agosto representam o período do ano com temperaturas menos elevadas, sendo junho o mês mais frio, com temperatura média de $18,4^{\circ} \mathrm{C}$, desvio padrão de $1,1^{\circ} \mathrm{C}$, coeficiente de variação de $6 \%$ e temperatura média máxima de $25,3^{\circ} \mathrm{C}$ e média mínima de $23,6^{\circ} \mathrm{C}$. O mês do ano com maior coeficiente de variação é outubro $(\mathrm{CV}=27 \%)$, mostrando-se o mês com maior variabilidade para a temperatura média do ar. Os meses com menor coeficiente de variação são dezembro e janeiro $(\mathrm{CV}=1,8 \%)$, com baixíssima variabilidade, ou seja, a temperatura manteve-se próxima de um valor constante para todos os meses de dezembro e janeiro da série.

Tabela 43 - Valores da temperatura média, desvio padrão (DP) e coeficiente de variação (CV) da temperatura média anual e mensal no município de São Simão/SP para os anos de 1994 a 2009.

\begin{tabular}{cccccc}
\hline Anual/mensal & $\begin{array}{c}\text { Med Med } \\
\left({ }^{\mathbf{0}} \mathbf{C}\right)\end{array}$ & $\begin{array}{c}\text { DP } \\
\left({ }^{\mathbf{}} \mathbf{C}\right)\end{array}$ & $\begin{array}{c}\text { CV } \\
(\boldsymbol{\%})\end{array}$ & $\begin{array}{c}\text { MaxMed } \\
\left({ }^{\mathbf{}} \mathbf{C}\right)\end{array}$ & $\begin{array}{c}\text { MinMed } \\
\left({ }^{\mathbf{}} \mathbf{C}\right)\end{array}$ \\
\hline jan & 24,4 & 0,4 & 2,0 & 25,3 & 23,6 \\
fev & 24,1 & 0,6 & 2,5 & 24,9 & 22,8 \\
mar & 24,1 & 0,6 & 2,5 & 25,0 & 23,0 \\
abr & 22,6 & 0,8 & 4,0 & 24,3 & 21,3 \\
mai & 19,8 & 2,7 & 13,0 & 29,6 & 18,1 \\
jun & 18,4 & 1,1 & 6,0 & 20,3 & 16,5 \\
jul & 18,7 & 0,9 & 6,0 & 20,4 & 17,2 \\
ago & 20,9 & 1,1 & 5,0 & 23,1 & 18,6 \\
set & 21,4 & 0,9 & 4,5 & 24,6 & 21,4 \\
out & 22,6 & 6,1 & 27,0 & 26,9 & 21,6 \\
nov & 24,1 & 0,6 & 2,5 & 25,5 & 23,1 \\
dez & 24,2 & 0,5 & 2,0 & 25,1 & 23,6 \\
Anual & $\mathbf{2 0 , 9}$ & $\mathbf{0 , 5}$ & $\mathbf{2 , 5}$ & $\mathbf{2 3 , 2}$ & $\mathbf{2 0 , 6}$ \\
\hline
\end{tabular}

A análise da distribuição do Gráfico 53 mostra que dos dezesseis anos, seis apresentaram temperatura média anual acima da média da série, seis anos abaixo e quatro anos com valores praticamente iguais à média, mostrando ausência de variabilidade, também pelo desvio padrão de $0,5^{\circ} \mathrm{C}$ e o coeficiente de variação de $2,5 \%$, conforme a Tabela 43 . O Gráfico 53, mostra, também, que, com exceção dos valores um pouco mais extremos ocorridos em 2001 e 2002, os registrados para os outros anos foram bem próximos da situação média. 


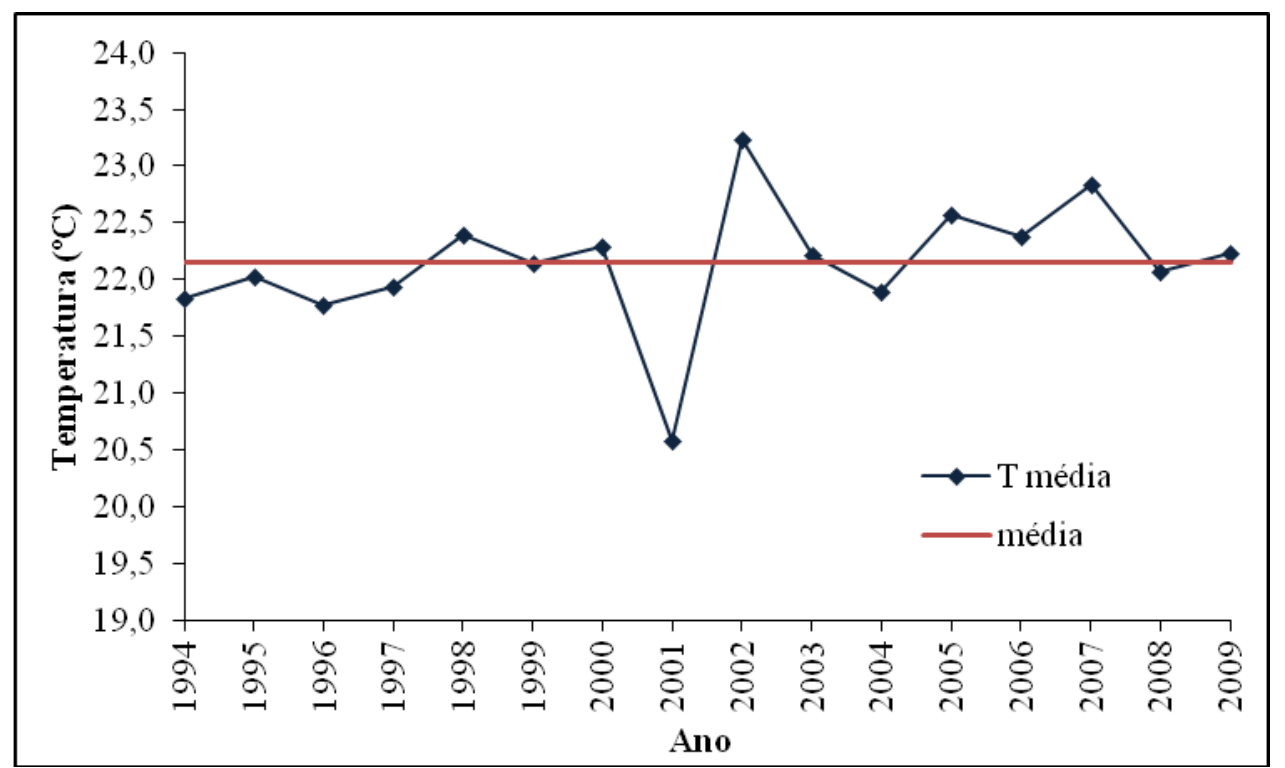

Gráfico 53 - Temperatura média anual no município de São Simão/SP para os anos de 1994 a 2009.

\subsubsection{2 - Temperatura máxima}

A Tabela 44 demonstra que a média das temperaturas máximas para o período é de $37,2^{\circ} \mathrm{C}$ sendo a maior máxima, $39,4^{\circ} \mathrm{C}$, ocorrida em 2002 e a menor,de $35,4^{\circ} \mathrm{C}$, em 1996. A amplitude térmica desse período resultou em $4^{\circ} \mathrm{C}$, indicando a ocorrência de pequena variabilidade anual das temperaturas máximas, com valores oscilando em torno da média, com exceção de dois valores um pouco acima.

Em relação ao comportamento mensal da temperatura máxima, a Tabela 45 evidencia que outubro é o mês mais quente da série, com temperatura média máxima de $36,6^{\circ} \mathrm{C}$, máxima de $39^{\circ} \mathrm{C}$ e mínima de $33,8^{\circ} \mathrm{C}$, com um desvio padrão de $1,5^{\circ} \mathrm{C}$ e coeficiente de variação de 4,1\%. O mês de junho configurou-se como o mais frio, com temperatura média máxima de $29,4^{\circ} \mathrm{C}$, máxima de $31,7^{\circ} \mathrm{C}$, mínima de $20,7^{\circ} \mathrm{C}$, desvio padrão de $2,5^{\circ} \mathrm{C}$ e coeficiente de variação de $8,5 \%$. A amplitude térmica de $7,2^{\circ} \mathrm{C}\left(36,6^{\circ} \mathrm{C}-29,4^{\circ} \mathrm{C}\right)$, aponta para uma acentuada variabilidade climática entre esses meses do período considerado. 
Tabela 44 - Valores da temperatura máxima anual no município de São Simão/SP para a série temporal de 1994 a 2009.

\begin{tabular}{cc}
\hline Ano & Tmáx $\left({ }^{\mathbf{O}} \mathbf{C}\right)$ \\
\hline 1994 & 36,3 \\
1995 & 36,1 \\
1996 & 35,4 \\
1997 & 37,1 \\
1998 & 35,8 \\
1999 & 39,0 \\
2000 & 38,1 \\
2001 & 36,1 \\
2002 & 39,4 \\
2003 & 38,5 \\
2004 & 37,4 \\
2005 & 36,9 \\
2006 & 37,2 \\
2007 & 38,6 \\
2008 & 38,4 \\
2009 & 35,5 \\
Med & $\mathbf{3 7 , 2}$ \\
\hline
\end{tabular}

Tabela 45 - Valores da temperatura máxima, desvio padrão (DP) e coeficiente de variação (CV) da temperatura média anual e mensal no município de São Simão/SP para os anos de 1994 a 2009.

\begin{tabular}{cccccc}
\hline Anu/mens & $\begin{array}{c}\text { Med Max } \\
\left({ }^{\mathbf{}} \mathbf{C}\right)\end{array}$ & $\begin{array}{c}\mathbf{D P} \\
\left({ }^{\mathbf{}} \mathbf{C}\right)\end{array}$ & $\begin{array}{c}\mathbf{C V} \\
(\mathbf{\%})\end{array}$ & $\begin{array}{c}\text { MaxMax } \\
\left({ }^{\mathbf{}} \mathbf{C}\right)\end{array}$ & $\begin{array}{c}\text { MinMax } \\
\left({ }^{\mathbf{}} \mathbf{C}\right)\end{array}$ \\
\hline jan & 34,7 & 1,1 & 3,3 & 37,2 & 33,1 \\
fev & 34,2 & 1,9 & 5,7 & 39,0 & 30,7 \\
mar & 34,2 & 0,9 & 2,8 & 35,5 & 32,3 \\
abr & 32,9 & 1,0 & 3,1 & 34,5 & 31,4 \\
mai & 31,3 & 1,0 & 3,2 & 33,0 & 29,8 \\
jun & 29,4 & 2,5 & 8,5 & 31,7 & 20,7 \\
jul & 31,3 & 1,2 & 3,7 & 33,2 & 29,4 \\
ago & 34,2 & 1,1 & 3,0 & 35,9 & 32,3 \\
set & 36,1 & 1,4 & 3,8 & 38,5 & 34,1 \\
out & 36,6 & 1,5 & 4,1 & 39,0 & 33,8 \\
nov & 35,3 & 0,9 & 2,4 & 37,1 & 34,1 \\
dez & 34,6 & 1,1 & 3,2 & 37,2 & 32,6 \\
Anual & $\mathbf{3 7 , 2}$ & $\mathbf{1 , 3}$ & $\mathbf{3 , 3}$ & $\mathbf{3 9 , 0}$ & $\mathbf{3 5 , 4}$ \\
\hline
\end{tabular}

A distribuição anual da temperatura máxima ao longo da série (gráfico 54), mostra que foram registrados sete valores abaixo da média $\left(37,2^{\circ} \mathrm{C}\right)$, seis acima da média e três 
valores coincidindo com a média, praticamente oscilando em torno do valor médio, com desvio padrão de $1,3^{\circ} \mathrm{C}$ e coeficiente de variação de $3,3 \%$, indicando baixa dispersão, inexistência de variabilidade, em acordo com o comportamento apresentado para temperatura média.

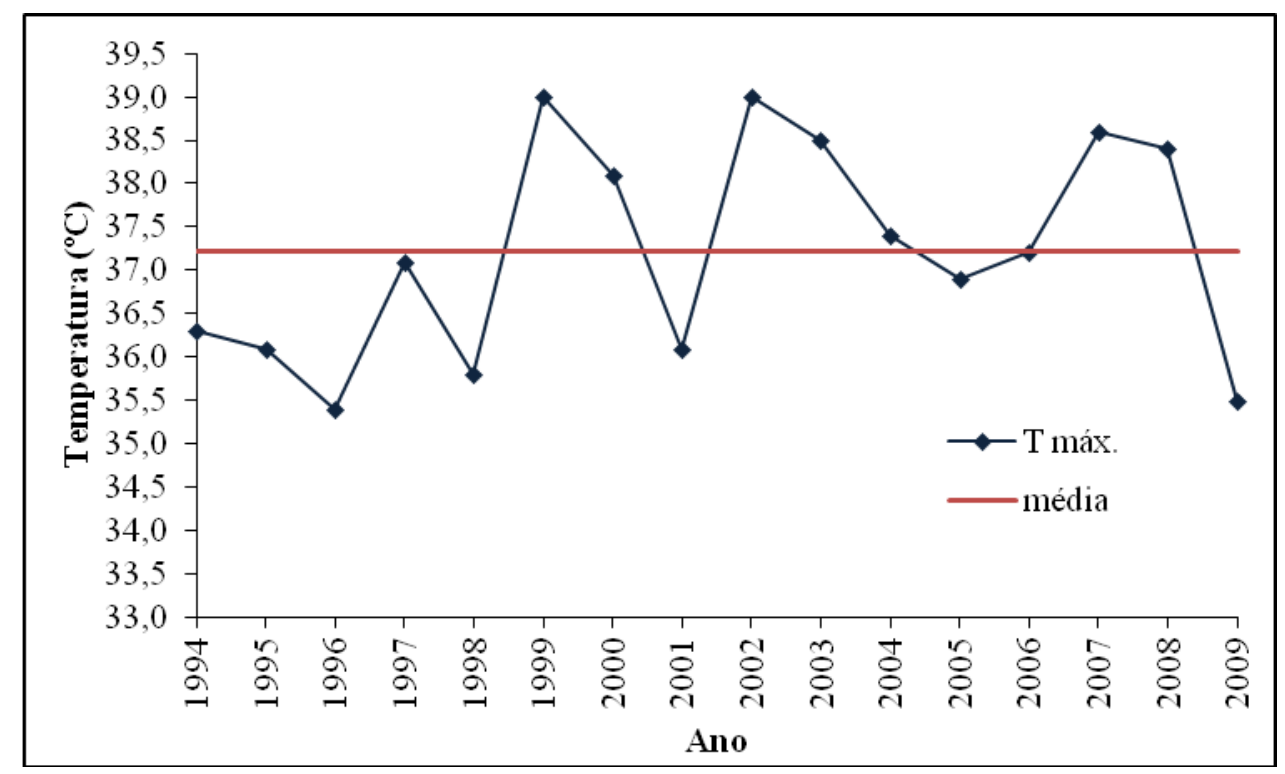

Gráfico 54 - Temperatura máxima anual no município de São Simão/SP para os anos de 1994 a 2009.

\subsubsection{3 - Temperatura mínima}

Em relação aos dados da Tabela 46, verifica-se que a média das temperaturas mínimas é $4,1^{\circ} \mathrm{C}$, com a menor temperatura mínima é $0^{\circ} \mathrm{C}$, registrada em 2001 e a maior, $7,6^{\circ} \mathrm{C}$, em 1995, determinando uma amplitude térmica de 7,6 $\mathrm{C}$ entre esses anos da série, indicativo de uma variabilidade bem mais acentuada para a temperatura mínima anual em relação ao ocorrido com as temperaturas média e máxima.

Analisando os dados mensais da Tabela 47 verifica-se que os valores indicam o mês de janeiro como o mais quente da série com temperatura média mínima de $17,8^{\circ} \mathrm{C}$, máxima de $20,1^{\circ} \mathrm{C}$ e mínima de $14,8^{\circ} \mathrm{C}$, com um desvio padrão de $1,5^{\circ} \mathrm{C}$ e coeficiente de variação de $8,3 \%$. Os meses de junho e julho, com valores bem próximos, mostraram-se os mais frios, com temperaturas médias mínimas de $6,0^{\circ} \mathrm{C}$ e $6,6^{\circ} \mathrm{C}$, máximas de $10^{\circ} \mathrm{C}$ e $10,5^{\circ} \mathrm{C}$ e mínimas de $2,3^{\circ} \mathrm{C}$ e $1,1^{\circ} \mathrm{C}$, respectivamente. Os desvios padrão tiveram valores iguais a $2,2^{\circ} \mathrm{C}$ e $2,7^{\circ} \mathrm{C}$, e os coeficientes de variação apresentaram valores de $37 \%$ e $27 \%$, respectivamente, indicando 
uma grande variabilidade térmica para esses dois meses. A amplitude térmica da temperatura média mínima é igual a $14,8^{\circ} \mathrm{C}\left(14,8^{\circ} \mathrm{C}-0,0^{\circ} \mathrm{C}\right)$, indicando a ocorrência de uma grande variabilidade climática entre os meses de janeiro e julho para a série estudada.

Tabela 46 - Valores da temperatura mínima, anual no município de São Simão/SP, para a série temporal de 1994 a 2009.

\begin{tabular}{cc}
\hline Ano & Tmin $\left({ }^{\mathbf{0}} \mathbf{C}\right)$ \\
\hline 1994 & 4,3 \\
1995 & 7,6 \\
1996 & 2,2 \\
1997 & 2,7 \\
1998 & 6,6 \\
1999 & 3,6 \\
2000 & 1,1 \\
2001 & 0,0 \\
2002 & 2,8 \\
2003 & 5,0 \\
2004 & 5,8 \\
2005 & 6,7 \\
2006 & 5,3 \\
2007 & 5,1 \\
2008 & 5,0 \\
2009 & 2,3 \\
Med & $\mathbf{4 , 1}$ \\
\hline
\end{tabular}

Tabela 47 - Valores da temperatura mínima, desvio padrão (DP) e coeficiente de variação (CV) da temperatura média anual e mensal no município de São Simão/SP para os anos de 1994 a 2009.

\begin{tabular}{cccccc}
\hline Anual/mensal & $\begin{array}{c}\text { Med Min } \\
\left({ }^{\mathbf{0}} \mathbf{C}\right)\end{array}$ & $\begin{array}{c}\text { DP } \\
\left({ }^{\mathbf{0}} \mathbf{C}\right)\end{array}$ & $\begin{array}{c}\mathbf{C V} \\
(\mathbf{\%})\end{array}$ & $\begin{array}{c}\text { MaxMin } \\
\left({ }^{\mathbf{}} \mathbf{C}\right)\end{array}$ & $\begin{array}{c}\text { MinMin } \\
\left({ }^{\mathbf{0}} \mathbf{C}\right)\end{array}$ \\
\hline jan & 17,8 & 1,5 & 8,3 & 20,1 & 14,8 \\
fev & 17,4 & 1,3 & 7,2 & 19,3 & 14,8 \\
mar & 16,3 & 1,2 & 7,5 & 18,1 & 14,4 \\
abr & 12,1 & 2,7 & 30 & 15,6 & 4,6 \\
mai & 7,3 & 2,2 & 30 & 10,2 & 3,6 \\
jun & 6,0 & 2,2 & 37 & 10 & 2,3 \\
jul & 6,6 & 2,7 & 27 & 10,5 & 1,1 \\
ago & 8,3 & 2,3 & 27 & 12,8 & 4,3 \\
set & 10,3 & 2,8 & 27 & 13,7 & 4,2 \\
out & 13,2 & 4,1 & 30,6 & 17,5 & 0 \\
nov & 14,7 & 1,8 & 12,5 & 18,4 & 12 \\
dez & 16,2 & 1,5 & 9 & 18,1 & 12,7 \\
Anual & $\mathbf{4 , 1}$ & $\mathbf{2 , 1}$ & $\mathbf{5 1 , 8}$ & $\mathbf{7 , 6}$ & $\mathbf{0}$ \\
\hline
\end{tabular}


O gráfico 55 mostra que a temperatura mínima sofreu grande variabilidade com três valores bem acima da média e dois, bem abaixo da média. Os anos seguintes apresentaram variabilidade um pouco menos acentuada, com as temperaturas oscilando em torno da média. Os últimos quatro anos da série apresentaram valores bem próximos da média, com variabilidade mais baixa.

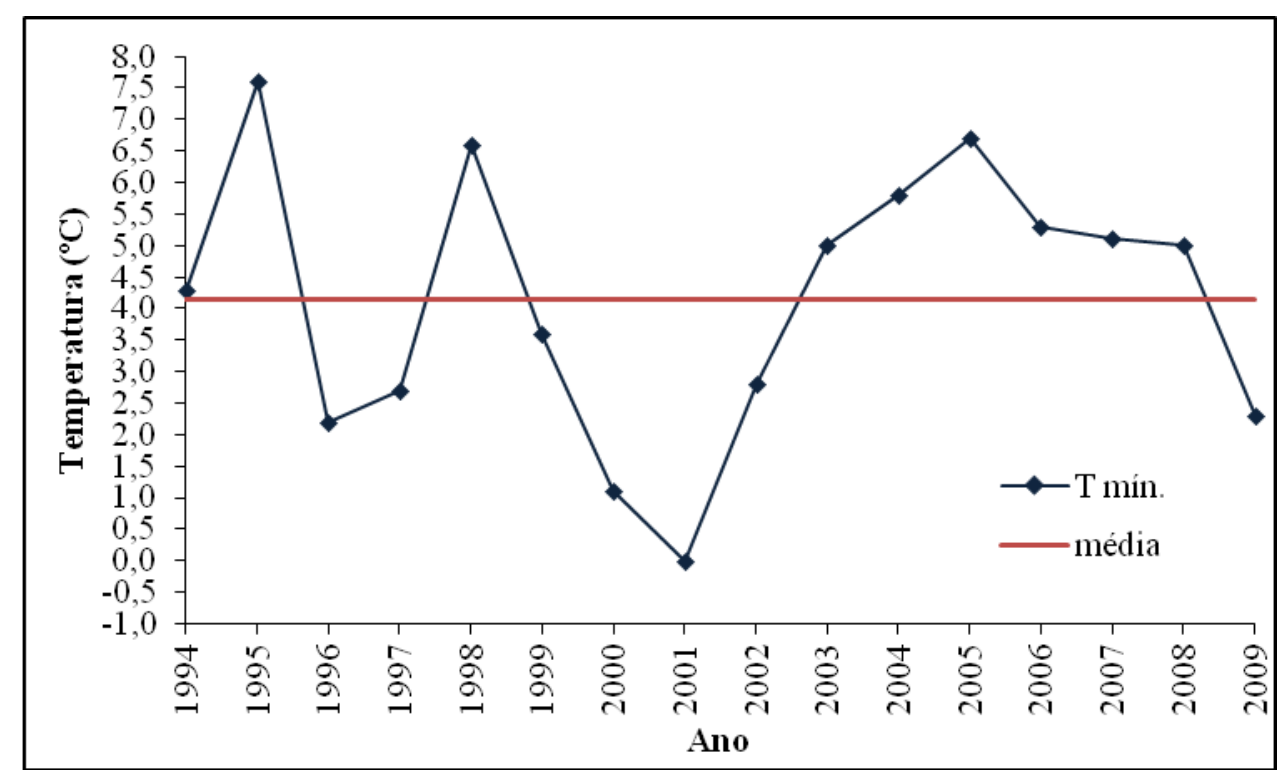

Gráfico 55 - Temperatura mínima anual no município de São Simão/SP para os anos de 1994 a 2009.

\subsubsection{4 - Temperatura média máxima}

O comportamento anual da temperatura média máxima mostra que não houve uma variabilidade estatística significativa para o período 1994-2009. De acordo com a Tabela 48 e o gráfico 57, a média para o período é de $29,7^{\circ} \mathrm{C}$, com máxima de $30,7^{\circ} \mathrm{C}$ em 2002 e a mínima de $28,9^{\circ} \mathrm{C}$, em 1996 , indicando uma estabilidade térmica para essa variável com os valores oscilando em torno de uma situação média. 
Tabela 48 - Valores da temperatura média máxima anual no município de São Simão/SP para a série temporal de 1994 a 2009.

\begin{tabular}{cc}
\hline Anual & Tmedmax $\left({ }^{\mathbf{0}} \mathbf{C}\right)$ \\
\hline 1994 & 29,2 \\
1995 & 29,5 \\
1996 & 28,9 \\
1997 & 29,5 \\
1998 & 29,7 \\
1999 & 29,7 \\
2000 & 29,6 \\
2001 & 30,4 \\
2002 & 30,7 \\
2003 & 30,0 \\
2004 & 29,0 \\
2005 & 29,7 \\
2006 & 29,9 \\
2007 & 30,4 \\
2008 & 29,5 \\
2009 & 29,5 \\
Med & $\mathbf{2 9 , 7}$ \\
\hline
\end{tabular}

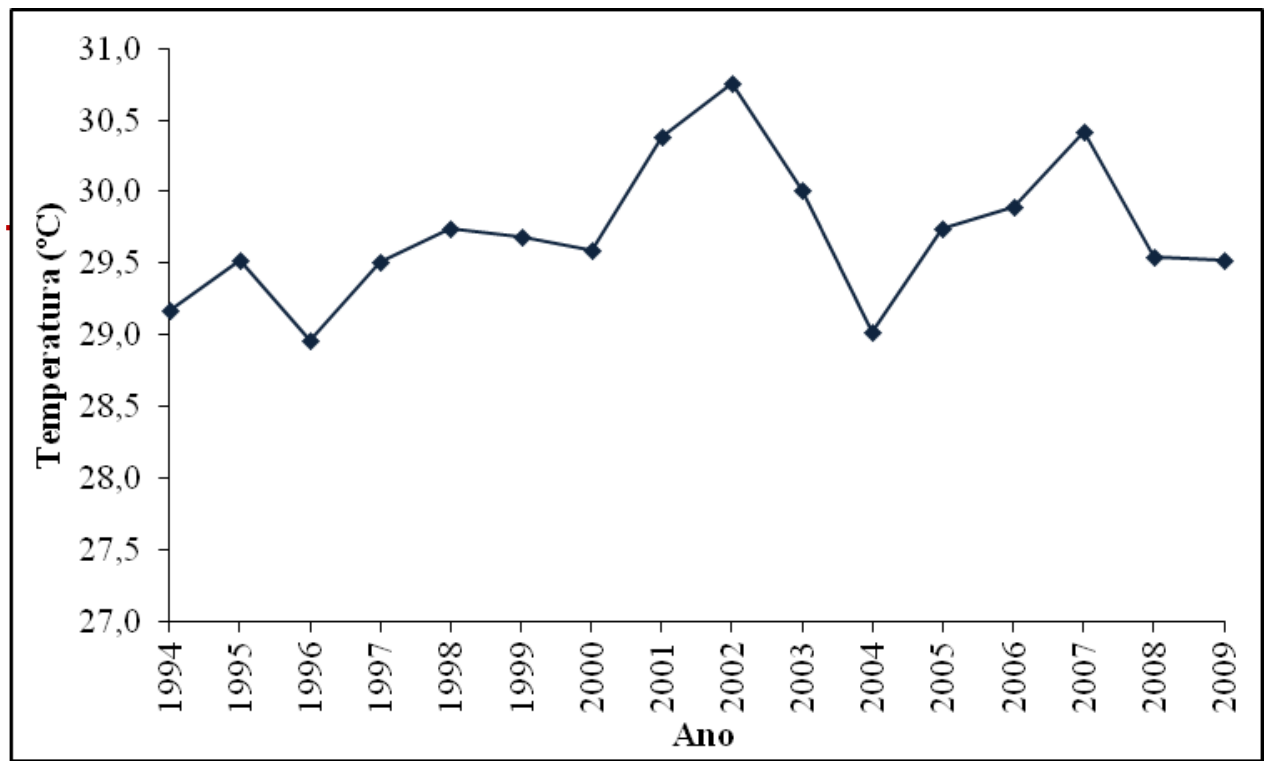

Gráfico 57 - Temperatura média máxima anual no município de São Simão/SP para os anos de 1994 a 2009. 


\subsubsection{5 - Temperatura média mínima}

Durante o período a temperatura média mínima oscilou entre os valores de $16,3^{\circ} \mathrm{C}$ em 2003 e $17,5^{\circ} \mathrm{C}$ em 2007 , com uma média de $16,7^{\circ} \mathrm{C}$ para o período, indicando ausência de variabilidade significativa para a série conforme mostra a Tabela 49 o Gráfico 58.

Tabela 49 - Valores da temperatura média mínima anual no município de São Simão/SP para a série temporal de 1994 a 2009.

\begin{tabular}{cc}
\hline Ano & Tmedmin \\
\hline 1994 & 16,8 \\
1995 & 16,4 \\
1996 & 16,6 \\
1997 & 16,5 \\
1998 & 17,2 \\
1999 & 16,6 \\
2000 & 16,8 \\
2001 & 16,7 \\
2002 & 17,5 \\
2003 & 16,3 \\
2004 & 16,5 \\
2005 & 17,2 \\
2006 & 16,6 \\
2007 & 17,1 \\
2008 & 16,5 \\
2009 & 16,8 \\
Med & $\mathbf{1 6 , 7}$ \\
\hline
\end{tabular}




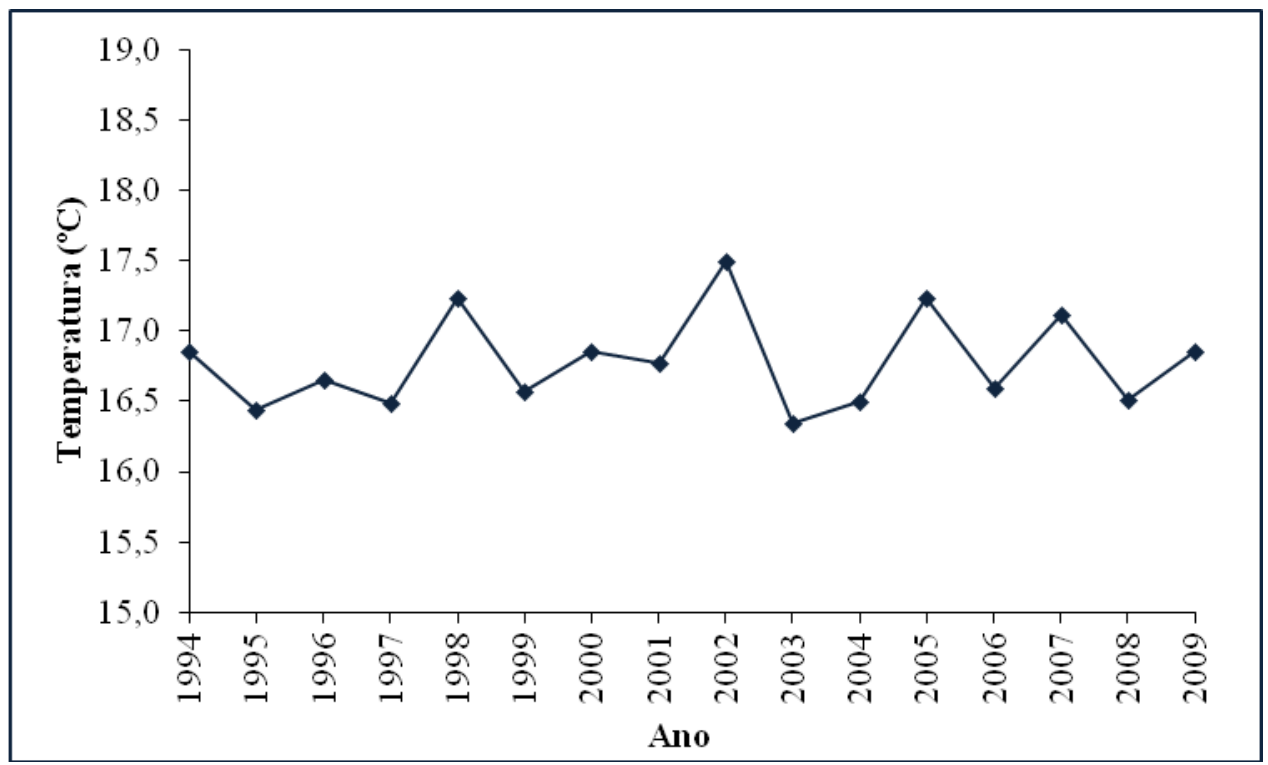

Gráfico 58 - Temperatura média mínima anual no município de São Simão/SP para os anos de 1994 a 2009.

\subsection{2 - Análise da tendência para as temperaturas médias, máximas, mínimas, média} máxima e média mínima: retas de regressão.

A temperatura média para o período apresenta uma tendência crescente correspondente a um acréscimo de $0,0363^{\circ} \mathrm{C} /$ ano ao longo dos dezesseis anos. O coeficiente de determinação é igual a 0,0931, explicando que a reta da temperatura média em relação ao tempo, ajusta-se em apenas 9,31\%, valor extremamente baixo, conforme mostra o Gráfico 59, Assim, a reta de regressão aponta para um acréscimo de aproximadamente $0,58^{\circ} \mathrm{C}$ na temperatura média anual durante o período, determinando uma tendência pouco significativa. 


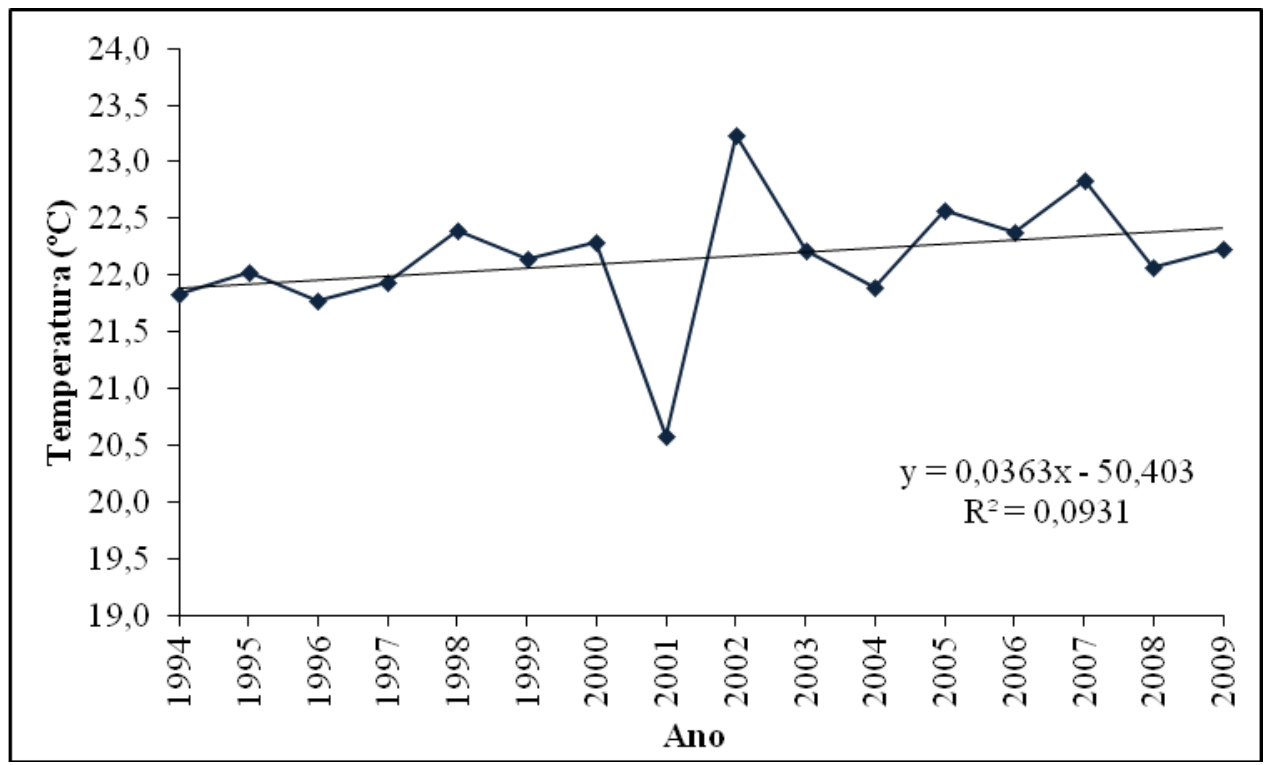

Gráfico 59 - Reta de regressão para a temperatura média anual no município de São Simão/SP para os anos de 1994 a 2009.

A análise do Gráfico 60 indica que a reta ajustada para o período mostrou uma tendência de acréscimo, evidenciada pelo coeficiente angular, e uma propensão à elevação da temperatura máxima à razão de $0,085^{\circ} \mathrm{C} / \mathrm{ano}$, totalizando um aumento de aproximadamente $1,3^{\circ} \mathrm{C}$ para os dezesseis anos de observação da série considerada, caracterizando-se como tendência significativa. A reta não se ajustou bem aos dados, fato demonstrado pelo coeficiente de determinação $\mathrm{R}^{2}$ igual a 0,1031 , ou seja $10,31 \%$ de ajuste.

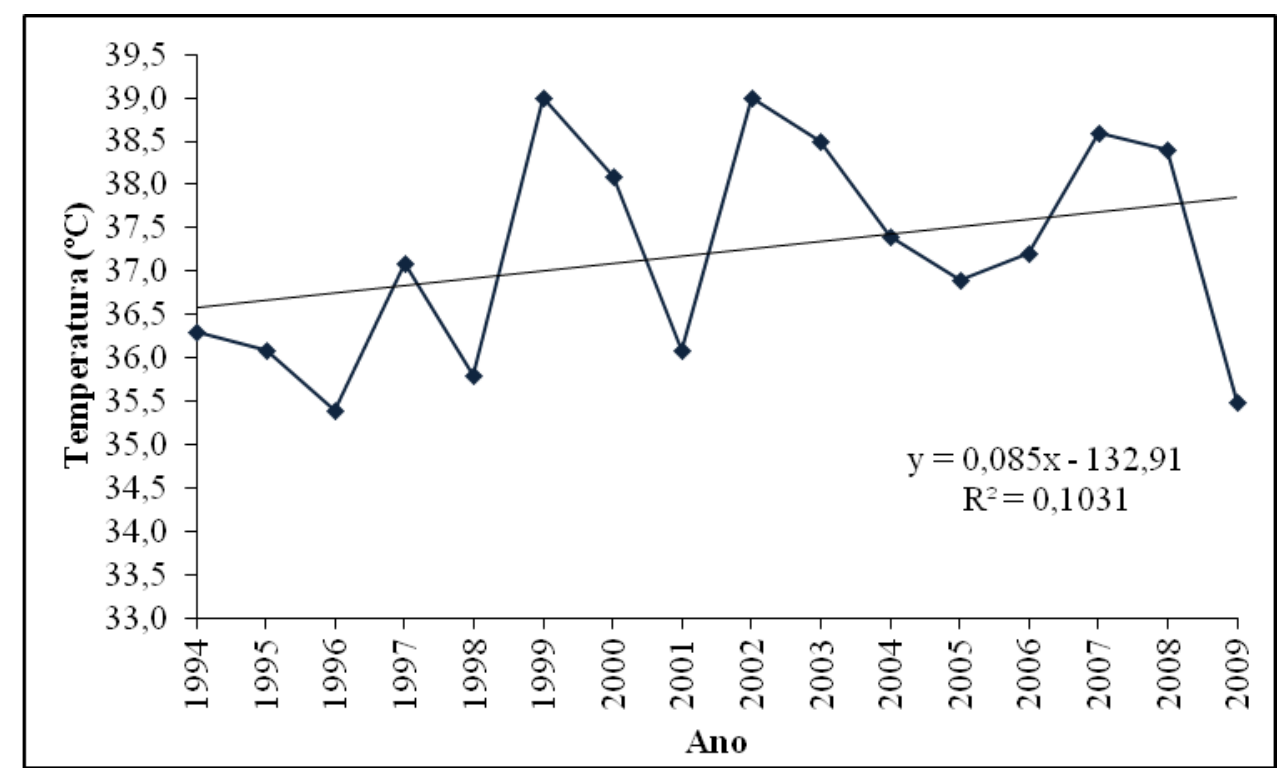

Gráfico 60 - Reta de Regressão para a temperatura máxima anual no município de São Simão/SP para os anos de 1994 a 2009. 
O Gráfico 61 mostra que ocorre uma tendência de aumento à razão de $0,026^{\circ} \mathrm{C} / \mathrm{ano}$, com $\mathrm{R}^{2}=0,0033$, indicando que a reta não se ajusta aos dados da série. O coeficiente angular da reta determina que, para os dezesseis anos da série, a temperatura mínima sofreria um acréscimo de aproximadamente $0,4^{\circ} \mathrm{C}$, valor indicativo de tendência pouco significativa para essa variável.

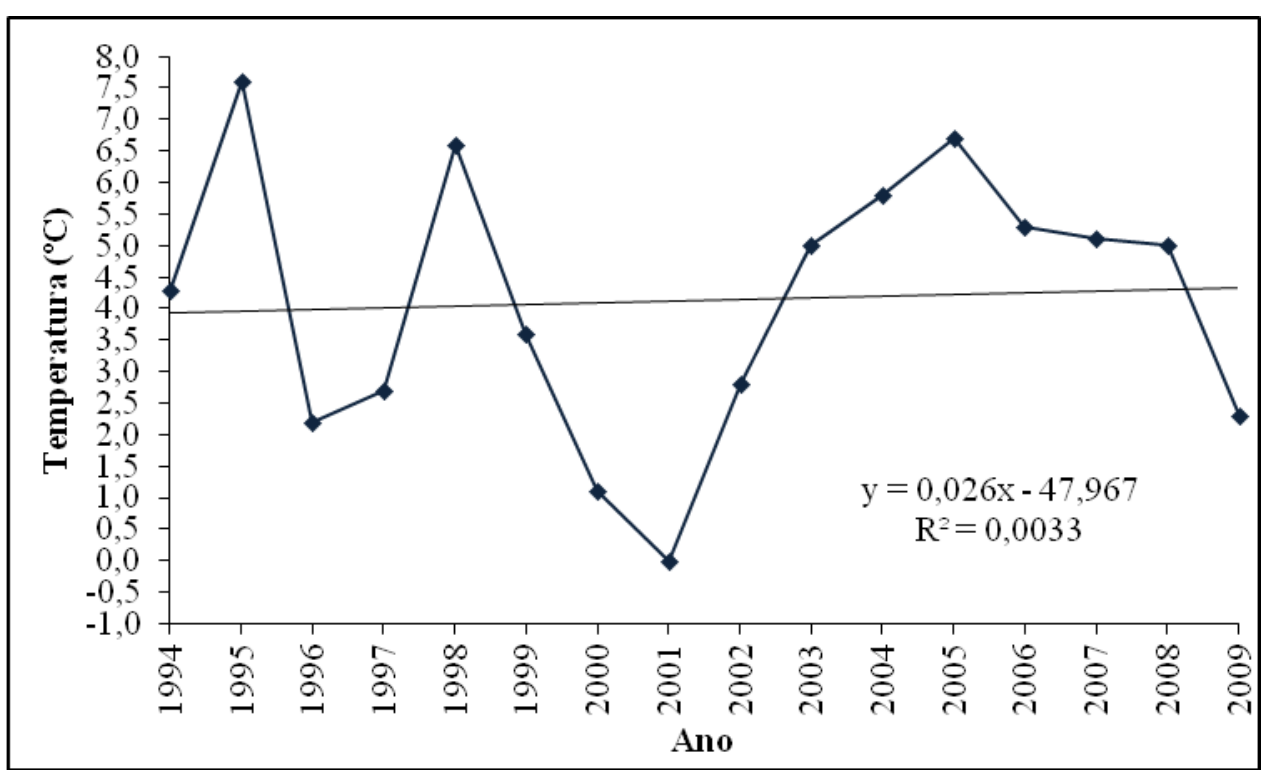

Gráfico 61 - Reta de Regressão para a temperatura mínima anual no município de São Simão/SP para os anos de 1994 a 2009.

A análise do Gráfico 62 mostra que a temperatura média máxima aponta para uma tendência de crescimento à taxa de $0,0345^{\circ} \mathrm{C} / \mathrm{ano}$, contabilizando $0,55^{\circ} \mathrm{C}$ ao longo da série de dezesseis anos para um coeficiente de determinação da reta ajustada aos dados, $R^{2}=0,1093$, indicando que apenas $10,93 \%$ da variação da temperatura média máxima estão associadas à variação temporal. O valor do acréscimo total da temperatura e a inclinação da reta evidenciam uma tendência pouco significativa. 


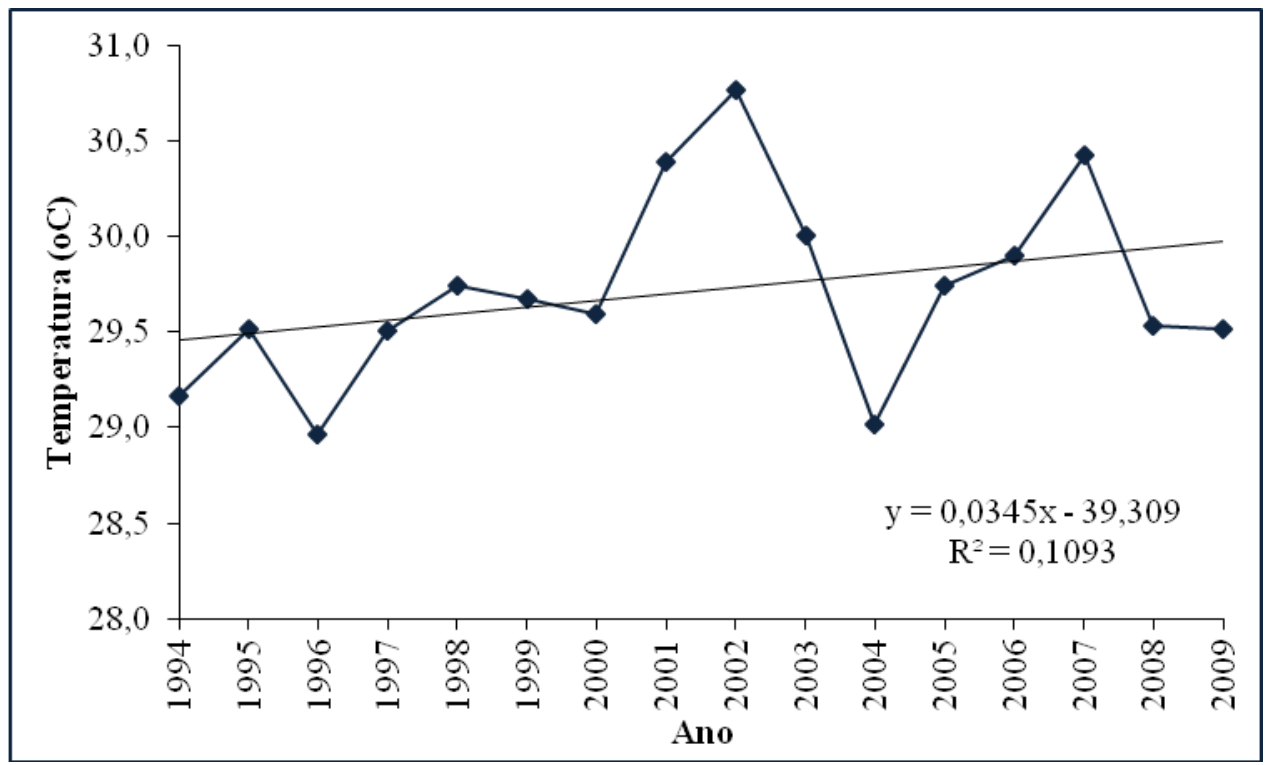

Gráfico 62 - Reta de regressão para a temperatura média máxima anual no município de São Simão/SP para os anos de 1994 a 2009.

A reta de regressão do Gráfico 63 aponta para uma mínima inclinação positiva nos valores da temperatura média mínima à taxa de $0,0086^{\circ} \mathrm{C} / \mathrm{ano}$, totalizando $0,13^{\circ} \mathrm{C}$ para a série toda, com tendência dessa variável não significativa e indicando estabilidade. Com o valor de $\mathrm{R}^{2}=0,0148$ fica evidente que a reta de regressão não foi ajustada aos dados, em razão da ausência de uma propensão manifestada pela temperatura média mínima.

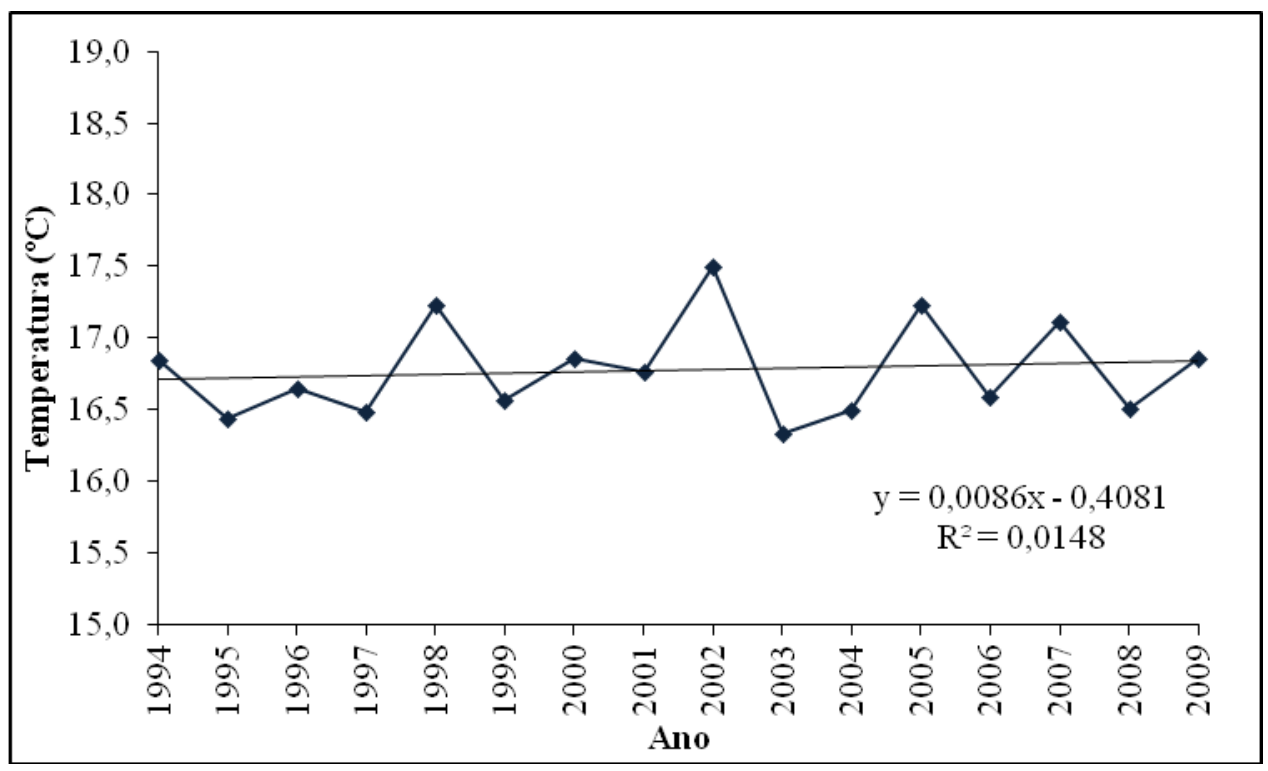

Gráfico 63 - Reta de regressão para a temperatura média mínima anual no município de São Simão/SP para os anos de 1994 a 2009. 


\subsection{3 - Análise da variabilidade para a pluviosidade}

Conforme se observa na Tabela 50, a série temporal estudada (1994 a 2009) registrou o total anual médio de 1486,8 mm, sendo 1995 o ano menos chuvoso (1094,2 mm), e 2005 e 2009, os mais chuvosos, com 1946,8 mm e 1943,8mm, respectivamente, valores extremos localizados no início e fim da série, mostrando uma variabilidade bastante acentuada.

Tabela 50 - Valores da pluviosidade total anual no município de São Simão/SP para a série temporal de 1994 a 2009.

\begin{tabular}{lc}
\hline Ano & Pluviosidade (mm) \\
\hline 1994 & 1502,90 \\
1995 & 1094,20 \\
1996 & 1765,50 \\
1997 & 1690,90 \\
1998 & 1390,60 \\
1999 & 1171,50 \\
2000 & 1487,80 \\
2001 & 1391,70 \\
2002 & 1466,00 \\
2003 & 1269,70 \\
2004 & 1283,30 \\
2005 & 1946,00 \\
2006 & 1605,50 \\
2007 & 1349,60 \\
2008 & 1430,60 \\
2009 & 1943,80 \\
Med & $\mathbf{1 4 8 6 , 8 0}$ \\
\hline
\end{tabular}

A Tabela 51 mostra o comportamento mensal da pluviosidade e a análise do período escolhido evidencia que sua distribuição é bastante variável ao longo do ano. As maiores pluviosidades ocorreram no quadrimestre de novembro, dezembro, janeiro e fevereiro, com precipitação média de 242,4 mm, para esses meses, com a máxima de $285,7 \mathrm{~mm}$ em janeiro. Também verificou-se que oito meses (fevereiro, abril, maio, junho, julho, agosto, setembro e outubro) tiveram pluviosidade mínima igual a zero para alguns anos ao longo da série, com destaque, principalmente, para os meses de fevereiro e outubro, habitualmente chuvosos. As estações com menor precipitação (secas) são geralmente o outono e o inverno, abrangendo os meses de abril a setembro, fato decorrente do clima tropical da região. 
Os meses da estação menos chuvosa, em geral, apresentam pluviosidades médias mensais abaixo de $60 \mathrm{~mm}$. Já o período compreendido entre o primeiro trimestre (janeiro, fevereiro e março) e o último (outubro, novembro e dezembro), apresenta valores médios de pluviosidade acima de $100 \mathrm{~mm}$. O trimestre menos chuvoso, constituído pelos meses de junho, julho e agosto, apresentou pluviosidade média abaixo dos $30 \mathrm{~mm}$.

A pluviosidade média anual no período foi de $1486,8 \mathrm{~mm}$, com desvio padrão de $249,8 \mathrm{~mm}$ e coeficiente de variação de $16 \%$.

Tabela 51 - Valores da média, desvio padrão (DP) e coeficiente de variação (CV) da pluviosidade média anual e mensal no município de São Simão/SP para os anos de 1994 a 2009.

\begin{tabular}{cccccc}
\hline Anual/mensal & $\begin{array}{c}\text { Média } \\
(\mathbf{m m})\end{array}$ & $\begin{array}{c}\text { DP } \\
(\mathbf{m m})\end{array}$ & $\begin{array}{c}\mathbf{C V} \\
(\mathbf{\%})\end{array}$ & $\begin{array}{c}\text { Max } \\
(\mathbf{m m})\end{array}$ & $\begin{array}{c}\text { Min } \\
(\mathbf{m m})\end{array}$ \\
\hline jan & 285,7 & 148,8 & 52 & 570,8 & 134,8 \\
fev & 246,0 & 137,9 & 56 & 596,2 & 0 \\
mar & 154,6 & 62,1 & 40 & 255 & 55,4 \\
abr & 59,1 & 38,1 & 64 & 134,6 & 0 \\
mai & 60,2 & 33,2 & 55 & 109 & 0 \\
jun & 23,6 & 33,7 & 143 & 130,8 & 0 \\
jul & 16,3 & 22,9 & 140 & 86,9 & 0 \\
ago & 24,3 & 35,7 & 147 & 141,3 & 0 \\
set & 62,6 & 52,9 & 84 & 198,3 & 0 \\
out & 116,2 & 65,0 & 55 & 233,6 & 0 \\
nov & 185,1 & 119,2 & 64 & 466,5 & 60,9 \\
dez & 253,2 & 99,0 & 39 & 461,3 & 95,7 \\
Anual & $\mathbf{1 4 8 6 , 8}$ & $\mathbf{2 4 9 , 8}$ & $\mathbf{1 6}$ & $\mathbf{1 9 4 6}$ & $\mathbf{1 0 9 4 , 2}$ \\
\hline
\end{tabular}

O Gráfico 64 mostra a distribuição da pluviosidade total anual para o período estudado. O gráfico permite constatar que a pluviosidade anual apresentou-se bem distribuída ao longo da série, com atenção para o valor mínimo registrado em 1995 e os máximos em 2005 e 2009. A pluviosidade anual média nesse período é de $1486,8 \mathrm{~mm}$, valor um pouco acima da normal climatológica de $1352 \mathrm{~mm}$, determinada pelo INMET. Verifica-se também que, para os dados referentes aos dezesseis anos de observação, apenas seis registraram pluviosidade acima da média, nove abaixo e um ano coincidindo com a média, indicativo de variabilidade bastante acentuada. 


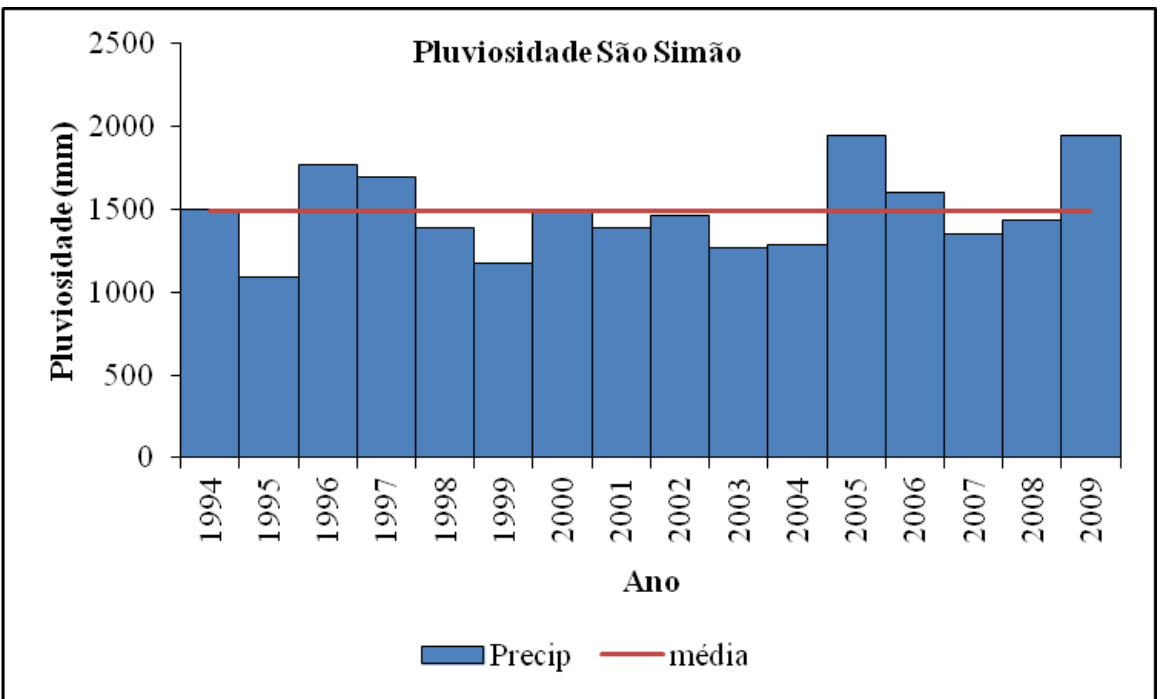

Gráfico 64 - Pluviosidade total anual no município de São Simão/SP para os anos de 1994 a 2009.

A curva do Gráfico 65 foi construída, também, com a finalidade de analisar a variabilidade da chuva em intervalos menores, apresentando períodos de dispersões mais ou menos acentuadas. O polinômio de grau cinco ajustado à série de dados anuais aponta para a grande variabilidade da pluviosidade, que, ao longo da série, apresentou valores oscilando entre 1100 e 1900 mm, com exceção para os anos de 2005 e 2009, com valores acima de 1900 $\mathrm{mm}$.

A análise por períodos mais curtos ao longo da série evidencia que a curva aponta maior variabilidade crescente entre 1994 e 1996, decrescendo suavemente de 1996 a 1999. Entre 1999 e 2002 volta a ter um comportamento levemente crescente e, após 2003 e 2004, volta a crescer mais acentuadamente até 2009 , evidenciando a grande variabilidade do regime de chuvas para a localidade. 


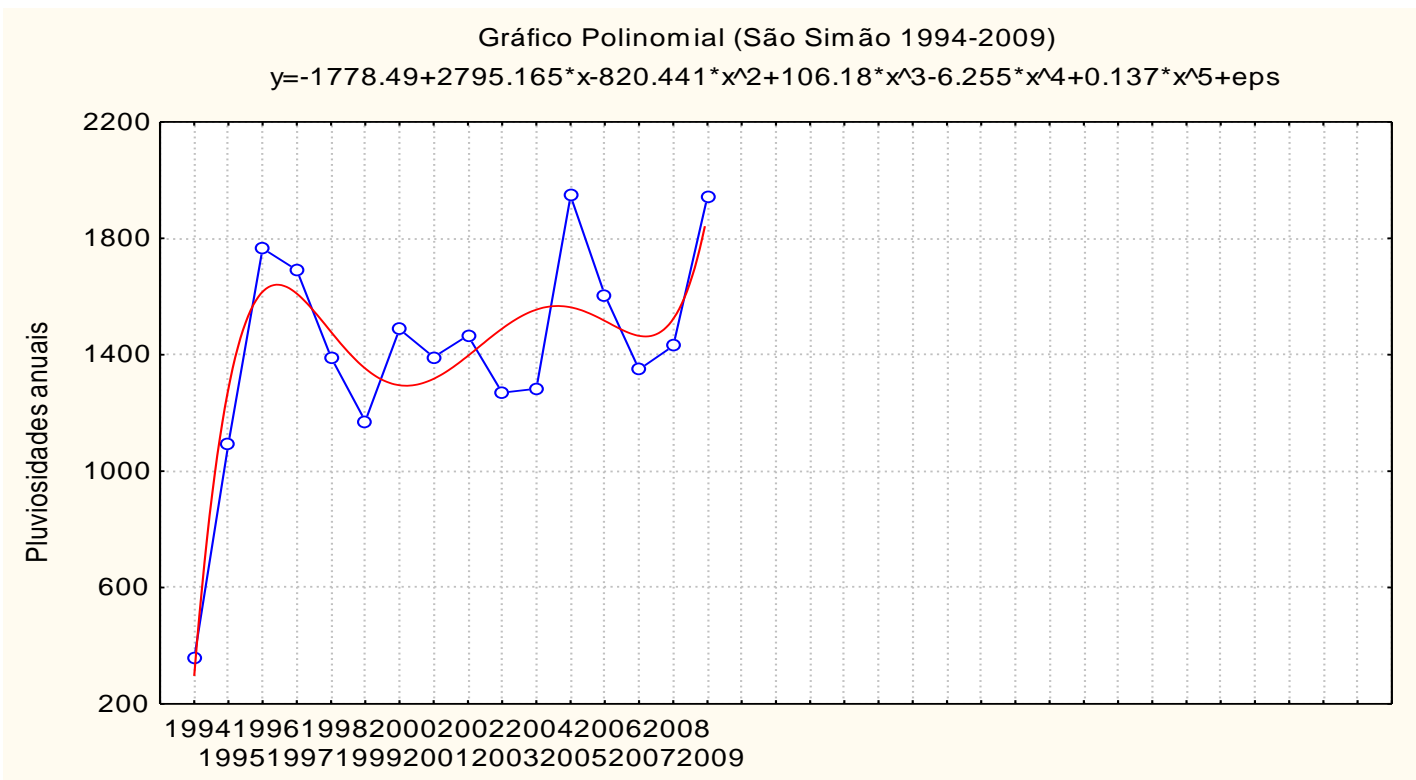

Gráfico 65 - Pluviosidade total anual de São Simão/SP de 1994 a 2009, curva de regressão polinomial de grau 5.

\subsection{4 - Análise da tendência para a pluviosidade: reta de regressão}

O Gráfico 66 mostra a reta de tendência para a pluviosidade. O coeficiente angular da reta de regressão determina um acréscimo de 13,985 mm/ano de chuva ao longo da série, perfazendo um total de $223,7 \mathrm{~mm}$, o que pode ser considerado uma elevação acentuada nos valores da pluviosidade no período considerado.

A análise dos dados indica, então, uma tendência de aumento nos valores da pluviosidade no local. $\mathrm{O}$ valor do coeficiente de determinação $\left(\mathrm{R}^{2}=0,071\right)$ mostra também que a reta de regressão não está ajustada aos dados; portanto, quase nenhuma variação da pluviosidade esteve bem associada ao tempo. Os dados obtidos permitem reconhecer que a tendência à elevação observada no comportamento da pluviosidade deves-se a variabilidade natural do clima local 


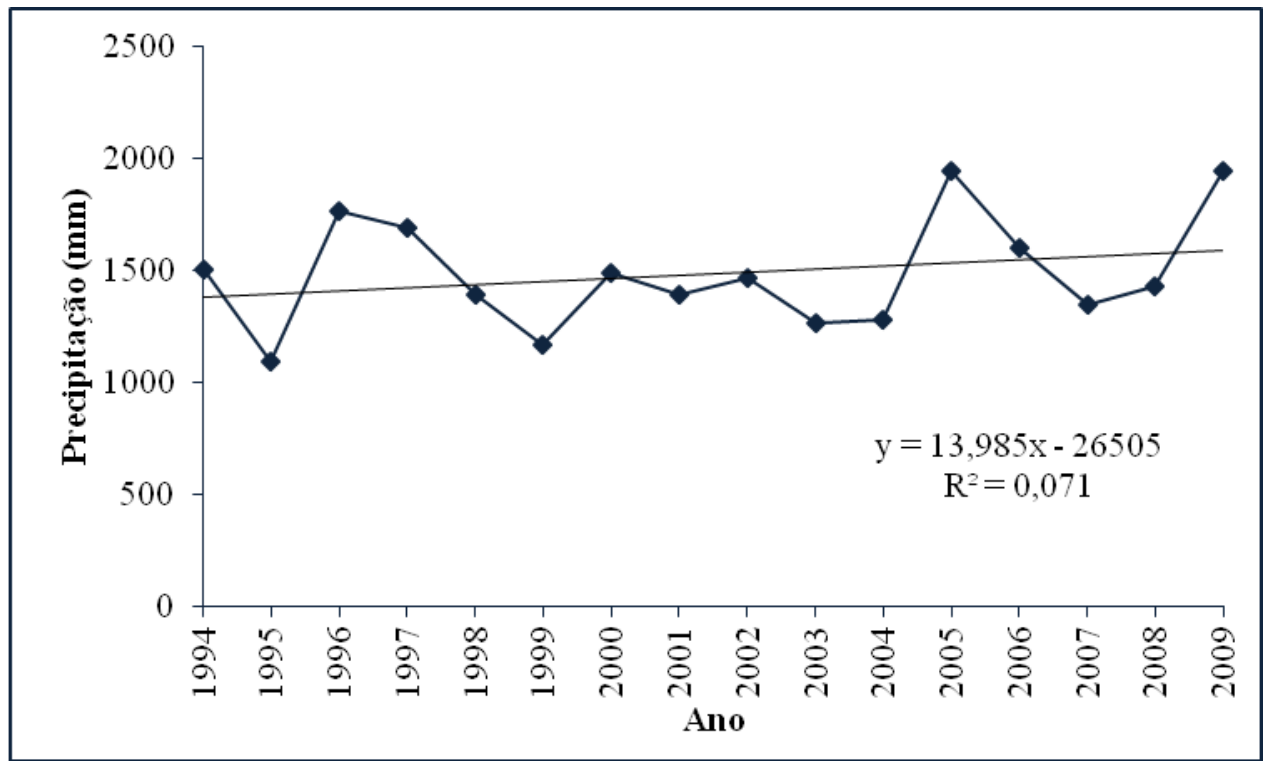

Gráfico 66 - Tendência da pluviosidade total anual no município de São Simão/SP no período de 1994 a 2009 - reta de regressão.

5.5.5 - Análise da tendência para a temperatura e pluviosidade: teste de Mann-Kendall e curvatura de Sen.

\subsubsection{1 - Medidas estatísticas das temperaturas máximas, médias máximas, mínimas,} médias mínimas, médias e pluviosidades em São Simão no período de 1994-2009.

Os aplicativos estatísticos Statistica e BioEstat forneceram resultados apresentados abaixo para a cidade de São Simão no período de 1994-2009.

Pode-se observar na Tabela 52 que há certa proximidade numérica entre as medidas estatísticas Mínimo, Máximo e M.A. para as colunas da temperatura máxima e média máxima e para a mínima e média mínima, diferentemente do que para a pluviosidade. O comportamento das medidas de variabilidade: desvio padrão (DP) e coeficiente de variação $\mathrm{CV}(\%)$ são baixos para as séries, indicando pouca variabilidade entre os dados. 
Tabela 52 - Medidas estatísticas de temperatura máxima, temperatura média máxima, temperatura mínima, temperatura média mínima, e pluviosidade para São Simão/SP.

\begin{tabular}{|l|c|c|c|c|c|}
\hline \multirow{2}{*}{ Estatística } & \multicolumn{5}{|c|}{ Variáveis Meteorológicas } \\
\cline { 2 - 6 } & $\begin{array}{c}\text { temperatura } \\
\text { máxima } \\
\left({ }^{\circ} \mathrm{C}\right)\end{array}$ & $\begin{array}{c}\text { temperatura } \\
\text { média máxima } \\
\left({ }^{\circ} \mathrm{C}\right)\end{array}$ & $\begin{array}{c}\text { temperatura } \\
\text { mínima } \\
\left({ }^{\circ} \mathrm{C}\right)\end{array}$ & $\begin{array}{c}\text { temperatura } \\
\text { média mínima } \\
\left({ }^{\circ} \mathrm{C}\right)\end{array}$ & $\begin{array}{c}\text { pluviosidade } \\
(\mathrm{mm})\end{array}$ \\
\hline Mínimo & 32,73 & 28,96 & 11,20 & 16,34 & 356,80 \\
Máximo & 34,73 & 30,76 & 15,30 & 19,70 & 1947,01 \\
M. A. & 33,75 & 29,79 & 12,32 & 16,95 & 1415,21 \\
DP & 0,5565 & 0,4957 & 0,9661 & 0,8041 & 376,90 \\
CV & 1,65 & 1,66 & 7,84 & 4,74 & 26,63 \\
Assim. & 0,1077 & 0,2766 & 2,0373 & 2,9265 & $-1,2386$ \\
Curtose & $-0,3853$ & $-0,2199$ & 5,7574 & 9,8566 & 3,4476 \\
\hline
\end{tabular}

Onde: M. A. = Média Aritmética; D. P. = Desvio Padrão; CV = Coeficiente de Variação;

Assim. $=$ coeficiente de assimetria; Curtose $=$ Coeficiente de Curtose.

Em relação à assimetria, todas as séries são classificadas como assimétricas. As séries das colunas das temperaturas máximas, médias máximas, mínimas, e médias mínimas são assimétricas à direita, pois os coeficientes de assimetria são positivos, enquanto a distribuição da pluviosidade é assimétrica à esquerda, pois o coeficiente é negativo. Em relação à curtose, as colunas das temperaturas máximas e médias máximas classificam-se como platicúrticas (Coeficiente de Curtose <3), e as demais, como leptocúrticas (Coeficiente de Curtose >3).

\subsubsection{2 - Análises das tendências e das estimativas}

A seguir são apresentados resultados das análises das variáveis meteorológicas, de São Simão no período de 1994-2009, a partir dos testes estatísticos de Mann-Kendall (MK) e Curvatura de Sen (CS), considerando-se o nível de confiança de $95 \%$ ou $\alpha=5 \%$.

A Tabela 53 permite verificar que, para o resultado da coluna 3, das temperaturas mínimas, há tendência de $-0,0333$ (Mann-Kendall), decrescente ou negativa, pois $\mathrm{Z}<0$ e muito próximo de zero, sendo insignificante, pois $p>\alpha$; e que a tendência dessa variável é de diminuir aproximadamente $0,0070^{\circ} \mathrm{C} /$ ano. Para as colunas $1,2,4,5$ e 6 , das temperaturas máximas, médias máximas, médias mínimas, médias e pluviosidade, há tendências crescentes, pois $\mathrm{Z}>0$, insignificantes, pois $p>\alpha$. Para as colunas 1,5 e 6 as tendências são mais acentuadas, pois os valores de $\mathrm{Z}$ são mais próximos de 1 para cada uma delas. Pela curvatura 
de Sen, as magnitudes das tendências dessas colunas são respectivamente de, $0,0438^{\circ} \mathrm{C} / \mathrm{ano}$, $0,0066^{\circ} \mathrm{C} / \mathrm{ano}, 0,0007^{\circ} \mathrm{C} / \mathrm{ano}, 0,0358^{\circ} \mathrm{C} /$ ano e $22,3112 \mathrm{~mm} / \mathrm{ano}$.

Tabela 53 - Análise estatística das variáveis meteorológicas $(\alpha=5 \%)$ para São Simão/SP.

\begin{tabular}{|l|c|c|c|c|c|c|}
\hline \multirow{2}{*}{ Estatística } & \multicolumn{6}{|c|}{ Variáveis Meteorológicas } \\
\cline { 2 - 7 } & $\begin{array}{c}\text { temperatura } \\
\text { máxima } \\
\left({ }^{\circ} \mathrm{C}\right)\end{array}$ & $\begin{array}{c}\text { temperatura } \\
\text { média máxima } \\
\left({ }^{\circ} \mathrm{C}\right)\end{array}$ & $\begin{array}{c}\text { temperatura } \\
\text { mínima } \\
\left({ }^{\circ} \mathrm{C}\right)\end{array}$ & $\begin{array}{c}\text { temperatura } \\
\text { médias mínima } \\
\left({ }^{\circ} \mathrm{C}\right)\end{array}$ & $\begin{array}{c}\text { temperatura } \\
\text { média } \\
\left({ }^{\circ} \mathrm{C}\right)\end{array}$ & $\begin{array}{c}\text { pluviosidade } \\
(\mathrm{mm})\end{array}$ \\
\hline Escore Z & 1,6658 & 0,4963 & $-0,1351$ & 0,0451 & 1,6658 & 1,3957 \\
MK & 0,3167 & 0,1000 & $-0,0333$ & 0,0167 & 0,3167 & 0,2667 \\
$\mathrm{CS}$ & 0,0438 & 0,0066 & $-0,0070$ & 0,0007 & 0,0358 & 22,3112 \\
Prob. $(\mathrm{p})$ & 0,0957 & 0,6197 & 0,8926 & 0,9640 & 0,0957 & 0,1628 \\
\hline
\end{tabular}

Como se constatou para as colunas das temperaturas máximas, médias e pluviosidade ocorreu uma tendência mais acentuada (MK e Sen), é importante compará-las com as tendências determinadas pelo método das retas de regressão. Assim, do Gráfico 59 o coeficiente angular da reta de regressão determina que a tendência da temperatura média, é crescente, aumentando à taxa de $0,0363^{\circ} \mathrm{C} / \mathrm{ano}$, compatível com o resultado da Tabela 53, em que a tendência também é de crescimento à razão de $0,0358^{\circ} \mathrm{C} / \mathrm{ano}$.

Verifica-se, também, a partir do Gráfico 60 que o coeficiente angular é positivo; portanto, crescente, aumentando à taxa de $0,085^{\circ} \mathrm{C} / \mathrm{ano}$; e que da Tabela 53, MK indica tendência crescente, com magnitude de $0,0438^{\circ} \mathrm{C} / \mathrm{ano}$, medida pela curvatura de Sen, resultados diferentes quanto à magnitude, mas semelhantes quanto à tendência. Para a pluviosidade anual, embora insignificante por MK, ocorreu uma tendência mais acentuada, com acréscimo de 22,3112 mm/ano, (curvatura de Sen), totalizando 356,9 $\mathrm{mm}$ para a série toda. Comparando-se esse resultado com o obtido do Gráfico 66 (reta de regressão), constatase novamente a coerência quanto à tendência no acréscimo da pluviosidade de 13,985 $\mathrm{mm} / \mathrm{ano}$, no total de $223,7 \mathrm{~mm}$, resultados compatíveis pelos dois métodos. 
5.6 - Análise estatística dos dados de temperatura e pluviosidade da série temporal de 1994 a 2009 para Pirassununga, Rio Claro, São Carlos e São Simão: comparações entre os resultados obtidos pelo método de Mann-Kendall e Sen.

Nesta seção será analisado, estatisticamente, o comportamento das temperaturas, e pluviosidades anuais, para os municípios de Pirassununga, Rio Claro, São Carlos e São Simão, por considerarem esses atributos climatológicos representativos e significativos em relação às localidades escolhidas, principalmente as pluviosidades anuais, que têm implicação direta nas atividades de voo desenvolvidas na região.

A Tabela 54 contém a estatística $Z$ da série temporal de cada município estudado para uma análise das comparações das tendências das variáveis meteorológicas e a Tabela 55 apresenta as medidas das magnitudes das tendências, determinadas pela curvatura de Sen.

Tabela 54 - Análise comparativa da estatística Z das variáveis meteorológicas $(\alpha=5 \%)$.

\begin{tabular}{|l|c|c|c|c|c|}
\hline \multirow{2}{*}{ Estatística $(\mathbf{Z})$} & \multicolumn{5}{|c|}{ Variáveis Meteorológicas } \\
\cline { 2 - 6 } & $\begin{array}{c}\text { temperatura } \\
\text { máxima } \\
\left({ }^{\circ} \mathrm{C}\right)\end{array}$ & $\begin{array}{c}\text { temperatura } \\
\text { média máxima } \\
\left({ }^{\circ} \mathrm{C}\right)\end{array}$ & $\begin{array}{c}\text { temperatura } \\
\text { mínima } \\
\left({ }^{\circ} \mathrm{C}\right)\end{array}$ & $\begin{array}{c}\text { temperatura } \\
\text { média mínima } \\
\left({ }^{\circ} \mathrm{C}\right)\end{array}$ & $\begin{array}{c}\text { pluviosidade } \\
(\mathrm{mm})\end{array}$ \\
\hline São Simão & 1,6658 & 0,4963 & $-0,1351$ & 0,0451 & 1,3957 \\
São Carlos & 0,8112 & 0,6310 & 0,5853 & 0,4052 & 1,5758 \\
Rio Claro & $-0,0412$ & 0,2060 & 0,7828 & 0,1236 & $-0,9474$ \\
Pirassununga & 0,8572 & 1,1718 & 1,2181 & 0,6310 & 0,1351 \\
\hline
\end{tabular}

Tabela 55 - Análise comparativa da estatística curvatura de Sen das variáveis meteorológicas.

\begin{tabular}{|l|c|c|c|c|c|c|}
\hline \multirow{2}{*}{$\begin{array}{c}\text { Curvatura } \\
\text { de Sen }\end{array}$} & \multicolumn{7}{|c|}{ Variáveis Meteorológicas } \\
\cline { 2 - 7 } & $\begin{array}{c}\text { temperatura } \\
\text { máxima } \\
\left({ }^{\circ} \mathrm{C}\right)\end{array}$ & $\begin{array}{c}\text { temperatura } \\
\text { média máxima } \\
\left({ }^{\circ} \mathrm{C}\right)\end{array}$ & $\begin{array}{c}\text { temperatura } \\
\text { mínima } \\
\left({ }^{\circ} \mathrm{C}\right)\end{array}$ & $\begin{array}{c}\text { temperatura } \\
\text { média mínima } \\
\left({ }^{\circ} \mathrm{C}\right)\end{array}$ & $\begin{array}{c}\text { temperatura } \\
\text { média } \\
\left({ }^{\circ} \mathrm{C}\right)\end{array}$ & $\begin{array}{c}\text { pluviosidade } \\
(\mathrm{mm})\end{array}$ \\
\hline São Simão & 0,0438 & 0,0066 & $-0,0070$ & 0,0007 & 0,0358 & 22,3112 \\
São Carlos & 0,0388 & 0,0300 & 0,0274 & 0,0222 & $-0,0519$ & 21,675 \\
Rio Claro & $-0,0012$ & 0,0076 & 0,0249 & 0,0025 & 0,0333 & $-17,454$ \\
Pirassununga & 0,0938 & 0,0500 & 0,0900 & 0,0386 & $-0,0840$ & 2,0600 \\
\hline
\end{tabular}

A análise da tabela possibilita verificar que, pelos resultados da coluna 1, temperatura máxima, que São Simão, São Carlos e Pirassununga apresentaram medidas de Z bem próximas, principalmente São Carlos e Pirassununga, mostrando que a tendência da temperatura máxima é de aumento nos valores ao longo da série para essas duas localidades, acrescentando-se, ainda, que, para Pirassununga, a magnitude da tendência é de $0,0938^{\circ} \mathrm{C} / \mathrm{ano}$, 
maior que São Carlos, que acusa o valor de $0,0388^{\circ} \mathrm{C} /$ ano, enquanto para São Simão o valor é intermediário, igual a $0,0438^{\circ} \mathrm{C} / \mathrm{ano}$. A discrepância dessa variável ocorre em Rio Claro, pois, mesmo estando próxima de Pirassununga e São Carlos, a tendência é de diminuição à razão de $0,0012^{\circ} \mathrm{C} / \mathrm{ano}$.

A análise para a temperatura mínima mostra que São Simão tem tendência negativa; portanto, de decrescimento à razão de $0,007^{\circ} \mathrm{C} / \mathrm{ano}$, considerada insignificante, pois, se essa tendência permanecesse por um século, totalizaria apenas $0,7^{\circ} \mathrm{C}$. Para as outras três localidades a tendência é de aumento nos valores ao longo dos dezesseis anos, à razão de 0,0274 $\mathrm{C}$ /ano em São Carlos, $0,0249^{\circ} \mathrm{C} /$ ano em Rio Claro e $0,05^{\circ} \mathrm{C} /$ ano em Pirassununga.

Para a temperatura média, a análise mostra que em São Simão e Rio Claro a tendência é de aumento à razão de $0,0358^{\circ} \mathrm{C} /$ ano e $0,0333^{\circ} \mathrm{C} / \mathrm{ano}$, respectivamente, ou seja, valores praticamente iguais, indicando mesma tendência com mesma magnitude. Já para São Carlos e Pirassununga a tendência é de diminuição à razão de $0,0519^{\circ} \mathrm{C} / \mathrm{ano}$ e $0,084^{\circ} \mathrm{C} / \mathrm{ano}$, respectivamente.

A análise das medidas estatísticas da pluviosidade mostra que para São Simão, São Carlos e Pirassununga a tendência é de aumento das chuvas à razão de 22,3112 mm/ano, $21,675 \mathrm{~mm} /$ ano e 2,06 mm/ano, respectivamente, indicando que os aumentos relativos a São Simão e São Carlos são bem próximos, maiores que os de Pirassununga, mas, ainda assim, pouco significativos. Para Rio Claro a tendência é de diminuição das chuvas à razão de $17,454 \mathrm{~mm} / \mathrm{ano}$, novamente apresentando-se discrepante, tendo em vista a proximidade de Pirassununga e São Carlos. 


\section{6 - CONSIDERAÇÕES FINAIS}

Ao final da pesquisa e de todas as análises realizadas sobre a variabilidade e a tendência climática na região estudada, principalmente as atividades de interpretação dos dados e aplicações das diferentes técnicas estatísticas, é possível a apresentação de algumas considerações gerais e conclusões.

\section{Variabilidade da pluviosidade}

A análise das séries para Pirassununga mostrou uma variabilidade anual bastante acentuada, com destaque para o ano de 1983, com 2069,1 mm, coincidindo com o período de manifestação do El Niño. A pluviosidade média ficou em torno de 1304,1 mm, valor muito próximo da Normal Climatológica, que registrou $1352 \mathrm{~mm}$. Em relação ao nível mensal, agosto foi o mês da série com maior variabilidade, com coeficiente de variação (CV) de $122 \%$. Os meses de junho, julho, agosto e setembro apresentaram índices nulos de pluviosidade, para vários anos da série.

Verifica-se, também, para Pirassununga que o trimestre mais chuvoso ocorre nos meses de dezembro, janeiro e fevereiro, compatível com o que acontece no estado de São Paulo, de acordo com Sant'Anna Netto (1995), argumentando que a presença do oceano é, sem dúvida, o fator determinante no retardamento do início de chuvas.

Outra consideração importante constatada por esta pesquisa refere-se à análise da estiagem climatológica (número de dias sem chuva), mostrando que a média de dias sem chuva varia de 23 dias em abril até 21 dias em outubro, atingindo o valor máximo de 28 dias, em julho. Isso significa que o período compreendido entre os meses de abril a outubro é o mais propício para o planejamento de atividades que dependem da variabilidade pluviométrica, como o planejamento da escala de voo para treinamento dos cadetes da AFA.

Em relação a Rio Claro verificou-se uma média de $1458 \mathrm{~mm}$ de chuva, um pouco acima da Normal climatológica. O mês de julho, com $\mathrm{CV}=146 \%$, apresentou a maior variabilidade entre os meses da série. Em São Carlos ocorreu o mesmo: média anual de 1481 mm e o mês de julho com CV $=140 \%$. Para São Simão a média anual foi de 1486,8 mm, sendo o mês de agosto, com CV $=147 \%$, o de maior variabilidade entre os meses da série. Para todas as localidades a ocorrência de três a quatro meses com precipitação nula é fator comprovado para a região. 
Verifica-se, então, que a pluviosidade para a região compreendida pelas quatro localidades apresenta variabilidade mensal e anual bastante acentuada, com algumas divergências devidas a fatores relacionados com as especificidades de cada uma. Diante da proximidade entre as localidades comparadas, espera-se que elas sejam afetadas de modo similar pelos efeitos causados pela circulação atmosférica regional. Assim é possível concluir, também, que quanto menor a variabilidade da pluviosidade, mais confiabilidade para se efetuar o planejamento de atividades em quase todos os setores.

\section{Tendência da pluviosidade.}

Os resultados obtidos mostram que, para Pirassununga, a tendência da pluviosidade determinada por Mann-Kendall é crescente, porém insignificante, com uma taxa de crescimento de 6,25 mm/ano (1976-2009) e 2,06 mm/ano (1994-2009). A tendência avaliada pela reta de regressão aponta para uma estabilidade para a série de 1976 a 2009 e para um crescimento de 9,52 mm/ano para a série de 1994 a 2009; portanto, compatíveis. Para Rio Claro, a tendência da pluviosidade é de diminuição tanto para Mann-Kendall, quanto para a reta de regressão, mas com índices também insignificantes, a uma taxa de 17,45 mm/ano. Os resultados obtidos para São Carlos mostraram uma tendência de aumento, à taxa de 21,67 mm/ano, considerada insignificante por Mann-Kendall O mesmo ocorreu para São Simão, com tendência crescente, à razão de 22,31 mm/ano, também insignificante.

As análises das medidas estatísticas realizadas nesta pesquisa mostram a inexistência de tendências significativas da pluviosidade nas quatro localidades e, para corroborar os resultados obtidos, tem-se, também, o trabalho desenvolvido por Berlato et al. (1995), que, estudando os dados de dezessete locais do Rio Grande do Sul, não identificaram tendências de longo prazo na precipitação pluvial anual, ressaltando que as reduções e incrementos observados em curto período referem-se, possivelmente, à flutuação natural da precipitação. Da mesma forma, Folhes \& Fish (2006), analisando as séries de precipitação total anual no período de 1983 a 2005 em Taubaté/SP e utilizando o teste de Mann-Kendall, também não encontraram tendência significativa para esta variável.

\section{Variabilidade da temperatura.}

Em relação à temperatura analisada para a série de 1976-2009, em Pirassununga os resultados mostraram temperaturas média, média máxima e média mínima com baixa 
variabilidade anual. A temperatura média apresentou grande variabilidade mensal, com destaque para julho, com $\mathrm{CV}=7 \%$. Já as temperaturas máximas e mínimas apresentaram variabilidade bastante acentuada, principalmente nos meses mais frios, mais especificamente em julho.

Ainda para Pirassununga, em relação à série de 1994 a 2009, a variabilidade anual para as temperaturas, média, máxima, mínima, média máxima e média mínima foi muito baixa, mantendo-se estável. A variabilidade mensal, novamente, foi maior para os meses do período seco e frio, com destaque para julho e setembro.

Para Rio Claro, São Carlos e São Simão a variabilidade anual das temperaturas foi baixa, próximas da estabilidade, com exceção da temperatura mínima que apresentou grande variabilidade para os três locais. Em relação à variabilidade mensal da temperatura mínima, novamente destaca-se o período frio, com o mês de junho apresentando maior variabilidade para as três localidades, com CV $=69 \%$ (Rio Claro), 103\% (São Carlos) e 37\% (São Simão).

\section{Tendência da temperatura}

Em Pirassununga, para a série 1976-2009, as tendências das temperaturas média, mínima e média mínima foram crescentes, mas insignificantes de acordo com Mann-Kendall. As temperaturas máximas e médias máximas apresentaram tendência crescente, tanto por Mann-Kendall, como pela reta de regressão, e significativas, com magnitudes medidas pela Curvatura de Sen, iguais a $0,08^{\circ} \mathrm{C} / \mathrm{ano}$ e $0,039^{\circ} \mathrm{C} / \mathrm{ano}$, respectivamente. Ainda em Pirassununga, para a série de 1994-2009, apenas a temperatura média apresentou tendência decrescente por Mann-Kendall e reta de regressão, e significativa, com uma taxa de diminuição de $0,084^{\circ} \mathrm{C} /$ ano. As demais temperaturas apresentaram tendências crescentes, mas não significativas.

Os resultados obtidos para as temperaturas de Rio Claro, São Carlos e São Simão, indicam tendência crescente e/ou decrescente, mas insignificante pelas medidas estatísticas de Mann-Kendall. A comparação dos resultados da tendência das temperaturas para as quatro localidades, ao longo da série 1994-2009, mostrou que apenas a temperatura média de Pirassununga apresentou tendência decrescente e significativa com diminuição de $0,084^{\circ} \mathrm{C} / \mathrm{ano}$, contabilizando $1,3^{\circ} \mathrm{C}$ para os dezesseis anos. Esse resultado é bastante significativo, pois, se a tendência permanecer, a indicação é de mais frio para os anos vindouros, na região. Porém, os valores médios dependem intrinsecamente dos valores 
máximos e mínimos e nenhum deles representa, isoladamente, um indicativo plenamente fiel e representativo de tendências de mudanças climáticas.

O estudo mostrou a necessidade de monitorar a variabilidade e a tendência climática na região para planejar eventos dependentes desses atributos, como a previsão para tempo impróprio para treinamento aéreo, planejamento de atividades de voo e, no contexto da agricultura, para auxiliar na definição de políticas públicas para o combate de pragas que se beneficiam da variabilidade e tendências dos atributos climáticos.

Após essas considerações e constatações a respeito dos resultados, é possível concluir que a pesquisa atingiu o objetivo proposto e que os mecanismos de análise utilizados mostraram que a variabilidade e tendência climática de curto prazo, em escala local, foram detectadas. Enfim, a presente pesquisa buscou contribuir tanto para os estudos sobre mudanças climáticas de curto prazo, em escala local, como também para a compreensão de como essas variações das condições climáticas podem auxiliar no planejamento de várias atividades importantes desenvolvidas na região de estudo, com ênfase para o planejamento das atividades aéreas da AFA. 


\section{REFERÊNCIAS BIBLIOGRÁFICAS}

ALEXANDER, L. V.; ZHANG, Y.; PETERSON, T. C.; CAESAR, J.; GLEASON, B.; TANK, A. M. K.; HAYLOCK, M.; COLLINS, D.; TREWIN, B.; TAGIPOUR, A.; KUMAR, K. R.; VINCENT, L.; STEPHENSON, D. B.; BUR, J.; AGUILAR, E.; TAYLOR, M.; ZHAI,P.; VAZQUEZ-AGUIRRE, J. L. Global observed changes in daily climate extremes of temperature and precipitation. Journal of Geophisical Research, Washington, v. 111, 2006. D05109, DOI: 10.1029/2005, JD 006290.

ALVES, A. R. Efeito estufa e mudanças climáticas. Ação Ambiental, v. IV, no 18, p. 715,2001 .

ALVES, K. J. F. Levantamento da avifauna do Campus UNESP - Rio Claro (Bairro Bela Vista). Trabalho de conclusão de curso. Rio Claro: Universidade Estadual Paulista "Júlio de Mesquita Filho”. Rio Claro, 2003.

ANUNCIAÇÃO, V. S. da. O clima urbano de Campo Grande, MS. Presidente Prudente, 2001. 121 f. Dissertação (Mestrado). Departamento de Geografia, FCT -Universidade Estadual Paulista.

AYOADE, J.O. Introdução à climatologia para os trópicos. Tradução de Maria Juraci Zani dos Santos. $4^{\text {a }}$ Edição. Rio de Janeiro: Bertrand Brasil. 1986.

BACK, A. J. Aplicação de análise estatística para identificação de tendências climáticas. Pesquisa Agropecuária Brasileira, v. 36, n. 5, 2001.

BERLATO, M. A.; FONTANA, D. C.; BONO, L. Tendência temporal da precipitação pluvial anual no Estado do Rio Grande do Sul. Revista Brasileira de Agrometeorologia, Santa Maria, v.3, p.111-113, 1995.

BESSAT, F. A. A mudança climática entre ciência, desafios e decisões: olhar geográfico. Terra livre. São Paulo. Ano 19, v. 1, n. 20, jan/jul - 2003.

BIERAS, A. R. Variabilidade e tendência climática e a produtividade de soja no estado de São Paulo. Rio Claro, 2006, (Tese de Doutorado) - Instituto de Geociências e Ciências Exatas, Universidade Estadual Paulista "Júlio de Mesquita Filho"- UNESP. 
BIERAS, A. R.; SANTOS, M. J. Z. Variabilidade e Tendência da Precipitação Pluviométrica Anual e Mensal do Município de Bebedouro (SP), no Período de 1983 A 2003. Climatologia e Estudos da Paisagem Rio Claro - Vol.1 - n.1/2, p. 63, julho/dezembro/2006.

BLAIN, G. C.; PICOLLI, M. C. A.; LULU, J. Análises Estatísticas das Tendências de Elevação nas Séries Anuais de Temperatura Mínima do Ar no Estado de São Paulo. Bragantia: Revista de Ciências Agronômicas, Campinas, v. 68, n. 3, p. 807-815,

BRUCE, J. P. The atmosphere of the living planet earth. Genève : World Meteorological Organization, 1990. 42 p. (WMO. 735)

BUFON, A. G. M. Variação temporal e espacial da taxa de sedimentação e das características limnológicas na microbacia do córrego da Barrinha, no município de Pirassununga, SP. Rio Claro, 2002,180 f. (Dissertação de Mestrado) - Gestão Integrada de Recursos, Centro de Estudos Ambientais, Universidade Estadual Paulista, Rio Claro.

CAMPOS, I. B.; RUIVO, B. C. Análise da Tendência climática para a Cidade de Corumbá (MGS). Anais do Segundo Simpósio de Geotecnologia no Pantanal, Corumbá, 711/novembro/2009. Embrapa Informática Agropecuária/INPE, p. 90-98.

CHRISTOFOLETTI, A. L. H. Estudo sobre a sazonalidade da precipitação na bacia do Piracicaba (SP). (Dissertação de Mestrado) São Paulo: Faculdade de Filosofia, Letras e Ciências Humanas da USP, 1991.

CHRISTOFOLETTI, A. L. H. Implicações geográficas relacionadas com as mudanças climáticas globais. Boletim de Geografia Teórica. Rio Claro, 23(45-45):18-31, 1993.

CHRISTOFOLETTI, A. L. H. Procedimentos de análise utilizados no estudo da precipitação. Geociências, São Paulo, v.11, n. 1, 1992.

COLABONE, R. O. Nevoeiro e dinâmica atmosférica: uma contribuição ao estudo sobre ocorrências de nevoeiro no aeródromo da Academia da Força Aérea - Pirassununga SP. (Tese de Doutorado). Programa de Pós-Graduação - área de concentração em Engenharia Ambiental - Escola de Engenharia de São Carlos da Universidade de São Paulo - USP, 2011

CONTI, J. B. Considerações sobre mudanças climáticas globais e regionais. Boletim de Geografia Teorética. Rio Claro, v. 23, n. 45 - 46, 1993. 
CONTI, J. B. Considerações sobre mudanças climáticas globais. In: SANT'ANA NETO, J. L. e ZAVATINI, J. A. (org). Variabilidade e mudanças climáticas. Maringá: Eduem, 2000, p. $17-28$.

CORDEIRO, A. P. A. Tendências Climáticas das Variáveis Meteorológicas Originais, Estimadas e das Derivadas do Balanço Hídrico Seriado do Estado do Rio Grande do Sul. Dissertação de Mestrado em Fitotecnia, Faculdade de Agronomia, Universidade Federal do Rio Grande do Sul, Porto Alegre, RS, Brasil. (274 p.). Agosto, 2010.

DAI, A.; FUNG, I.; GENIO, A. D. del. Surface observed global land precipitation variations during 1900-1988. Journal of Climate, Boston, v. 10, p. 2946-2962, 1997.

DAntas, A. A. A.; CARVAlHO, L. G.; FERrEIRA, E. Classificação e Tendências Climáticas em Lavras, MG. Revista Ciência e Agrotecnologia, Lavras, v.31, n.6, p.18621866, nov./dez. 2007.

DEO at al, On Australian heat waves: Time series analysis of extreme temperature events in Australia, 1950-2005. In MODSIM 2007 International Congress on Modeling and Simulation. Modeling and Simulation Society of Australia and New Zealand, p. 626-635, December (2007).

FECHINE, J. A. L. ; GALVÍNCIO, J. D. . Aplicação do Teste de Mann- Kendall na Análise de Tendências Climáticas em Anos de El Niño na Bacia Hidrográfica do Rio Pontal-Estado de Pernambuco. In: XVI Congresso Brasileiro de Meteorologia, Belém. Amazonia e o Clima Global. Belém: SBMET, 2010, v. 1, n.2, p. 1-5, 2010.

FLOHN, H. Some aspects of man made climate modification and desertification. Applied Sciences and Development, n. 10, p. 44-57, 1977.

FOLHES, M.T.; FISH, G. Caracterização climática e estudo de tendências nas séries temporais de temperatura do ar e precipitação em Taubaté (SP). Revista AmbiÁgua, Taubaté, v.1, n.1, p. 61-7, 2006.

FOLLAND, C.K., RAYNER, N.A., BROWN, S.J., SMITH, T.M., SHEN, S.S., PARKER, D.E., MACADAM, I., JONES, P.D., JONES, R.N., NICHOLLS, N., and SEXTON, D.M.H., 2001: Global temperature change and it uncertainties since 1861. Geophys. Res. Lett., in press

FISCH, G. Caracterização climática e balanço hídrico de Taubaté (SP). Revista Biociências, Taubaté, v. 1. n. 1, p. 81-90, 1995. 
FREI, C.; SCHAR, C. Detection probability of trends in rare events: Theory and application to heavy precipitation in the Alpine region. Journal of Climate, v.14, p.1568$1584,2000$.

FRICH, P.; ALEXANDER, L. V.; DELLA-MARTA, P.; GLEASON, G.; HAYLOCK, M.; PETERSON, T. Observed coherent changes in climate extremes during the second half of the century. Climate Research, Roskild, v.19, p. 193-212,2002.

GALINA, M. H. Mudanças climáticas de curto prazo: Tendências dos regimes térmicos e hídricos e do balanço hídrico nos municípios de Ribeirão Preto, Campinas e Presidente Prudente (SP) no período de 1969-2001. Rio Claro, 2002. Dissertação de Mestrado. Curso de Pós-Graduação em Geografia. Instituto de Geociências e Ciências Exatas. Campus de Rio Claro. Universidade Estadual Paulista.

GALINA, M. H.; AMARAL, R.; RIBEIRO, R. R. Mudanças climáticas de Curto Prazo: Análise da Variabilidade Térmica e Hídrica e do Balanço Hídrico na Localidade de Ribeirão Preto (SP). Anais do VIII Congresso de Ecologia do Brasil, Caxambú-MG, 2007

GALVANI, E. Sistematização de Dados Quantitativos. In: VENTURINI, L. A. B. (org.) Praticando a geografia: técnicas de campo e laboratório. São Paulo: Oficina de Textos, 2005, p.175-185.

GERARDI, L. H. de O.; SILVA, B. N. Quantificação em Geografia. São Paulo, SP: Ed. DIFEL, 1981. $163 \mathrm{p}$.

GILBERT, R. O. Statistical methods for environmental pollution monitoring. New York: Van Nostrand Reinhold, 320p. (1983).

GOOSSENS, C; BERGER, A. Annual and seasonal climatic variations over the northern hemisphere and Europe during the last century. Annales Geophysicae, Berlin, v.4, n.B4, p.385-400, (1986).

HIRSCH, R.M.; SLACK, J. R. A nonparametric trend test for seasonal data with serial dependence. Water Resources Research, v. 20, n.6, p.727 - 732, June (1984).

HOUGHTON, J. T.; CALlANDER, B. A.; VARNEY, S. K. (Ed.). Climate change 1992: the supplementary report to the IPCC scientific assessment. Cambridge (Inglaterra) : Cambridge University Press, 1992. 200 p.

HOUGHTON, J. T.; JENKINS, G. J.; EPHRAUMS, J. J. (Ed.). Climate change: the IPCC scientific assessment. Cambridge (Inglaterra) : Cambridge University Press, 1990. 364 P. 
Intergovernmental Panel on Climatic Change. IPCC Climate Change 2001: The scientific bias, in Houghton, J. t. and Ding, Y (eds.), Cambridge: Cambridge University Press, 2001.

Intergovernmental Panel on Climatic Change. IPCC Technical Guidelines for Assessing Climate Change Impacts and Adaptation. Cambridge: Cambridge University Press, 1995.

INVERNIZZI, A. L. Caracterização Hidrogeoquímica do Aquífero Botucatu, no setor médio da Bacia Hidrográfica Mogi-Pardo. (Dissertação de Mestrado). Programa de pósgraduação em geoquímica e geotectônica. Instituto de Geociências da USP - Universidade de São Paulo, 2001

KARL, P. D. et al. Indices of climate change for the United States. American Meteorological Society Bulletin, Boston, 1996. Apud, BACK, A. J. Aplicação de análise estatística para identificação de tendências climáticas. Pesquisa Agropecuária Brasileira, v. 36, n. 5, 2001

KENDALL, M. G.; Rank correlation methods. London: Charles Griffin, 120p. (1975).

KIM, I. S., BENETI, C. A., VISSOTTO JUNIOR, D. Um estudo de climatologia diária da temperatura e uma aplicação de "Model Output Statistics" (MOS) para a previsão de curto prazo no Estado do Paraná. Revista Brasileira de Geofísica v. 19 n.2, São Paulo, maio/agosto, 2001.

KUINCHTNER, A. Variabilidade da Temperatura Atmosférica Superficial no Planalto Meridional-Rio grandense. Dissertação de Mestrado. Universidade Federal do Rio Grande do Sul, Instituto de Geociências. Porto Alegre, 2006.

LIMA, W. P. Escoamento superficial, perdas de solo e de nutrientes em microparcelas reflorestadas com eucalipto em solos arenosos no município de São Simão, SP. IPEF, n.38, p.5-16, abr.1988. ESALQ-USP, Departamento de Ciências Florestais. Piracicaba - SP.

LOMBARDO, M. A. Mudanças climáticas recentes e ação antrópica. Revista do Departamento de Geografia da USP, São Paulo, v. 8, 1994.

MANN, H.B. Non-parametric tests against trend. Econometrica, v.13, p.245-259,1945.

MAREngO, J. A.; ALVES, L. M. Tendências hidrológicas da Bacia do Rio Paraíba do Sul. Revista Brasileira de Meteorologia, Rio de Janeiro, v.20, n. 2, p.215-226, 2005. 
MARIANO, J. Z. A importância da variável climática na produtividade da soja no sudoeste de Goiás. 2005. Tese (Doutorado em Geografia) IGCE/UNESP. Rio Claro.

MENDONÇA, F. Aquecimento global e saúde: uma perspectiva geográfica - notas introdutórias. Terra Livre, São Paulo, n. 20, p. 2005-221. 2003.

MINUZZI, R. B.; VIANELLO, R. L.; SEDIYAMA, G. C. Oscilações Climáticas em Minas Gerais. Revista Brasileira de Meteorologia, v. 25, n. 2, p. 227-236, 2010.

MINUZZI, R. B.; Tendência na Variabilidade Climática de Santa Catarina, Brasil. Revista Brasileira de Engenharia Agrícola e Ambiental, v. 14, n.12, p. 1288-1293, 2010, Campina Grande, PB, UAEA/UFCG.

MINUZZI, R. B.; CARAMORI, P. H.; Tendência Climática Sazonal e anual da quantidade de chuva no estado do Paraná. Revista Brasileira de Meteorologia, v. 25, n. 2, p. 237-246, 2010.

MIRANDA, E. E. Sistemas de gestão territorial para a ABAG/RP. Embrapa - Monitoramento por satélite, Campinas, 2005. Disponível em http://www.cdbrasil.cnpm.EMBRAPA.br . Acesso em 06/07/2012.

MOLION, L. C. B. Um século e meio de aquecimento global? Cadernos de Geociências, n. 15, p. $45-56.1995$.

MORETTIN, P. A.; BUSSAB, W. O. Estatística Básica, São Paulo: Editora Atlas, 2004

MOUVIER, G. La pollution atmosphérique. Flammarion. A poluição atmosférica. Editora Ática. São Paulo. 104 p

NATIONAL RESEARCH COUNCIL (Washington, Estados Unidos). Policy implications of greenhouse warming: mitigation, adaptation, and the science base. Washington : National Academy Press, 1992. 918 p

NUNES, L. H. Repercussões globais, regionais e locais do aquecimento global. Terra Livre. São Paulo, ano 19, v. 1, n. 20 jan/jul - 2003.

NUNES, L. H.; LOMBARDO, M. A. A questão da variabilidade climática: Uma reflexão crítica. Revista do Instituto Geológico de São Paulo/USP, 16 (1/2), p. 21-31, jan./dez. (1995). 
ÖNÖZ, B, BAYAZIT, M. C.. The power of statistical teste for trend detection, Turkish J. Eng. Env. Sci., v 27, p.247-251, 2003.

PACIORNICK, N., MACHADO FILHO, H. Política e Instrumentos Legais e Internacionais da Convenção Quadro das Nações Unidas sobre a Mudança do Clima In: MOREIRA, A. e SCHWARTZMAN, S. (ed.) As Mudanças Climáticas Globais e os Ecossistemas Brasileiros. O Brasil e o Panorama Internacional, Brasília, IPAA, 2000.

PAGANO, S. N.; CESAR, O., LEITÃO FILHO, H. de F. Composição florística do estrato arbustivoarbóreo da vegetação de Cerrado da Área de Proteção Ambiental (APA) de Corumbataí- Estado de São Paulo. Rev. Bras. Biol., Rio de Janeiro, v. 49, n. 1, p. 37-48, 1989.

PARKER, D. R.; FOLLAND, C. K. 1988. The nature of climatic variability. The Meteorological Magazine. 117 (1392): 201-216.

PETERSON, T C.; Taylor, M. A.; DEMERITTE, R.; DUNCOMB, D.; BURTON, S.; THOMPSON, F.; VILLEGAS, E.; FILLS,R. S.; TANK, A. K.; MARTIS, A.;JOYETTE, A.MILLS, W.; ALEXANDER L.; GLEASON, B. Recent Changes in Climate extremes in the Caribbean region. Journal of geophysical research, Washington, v. 107, n. D 21, 4601, 2002.

PONÇANO, W. T. et al. Mapa geomorfológico do Estado de São Paulo. São Paulo: Instituto de Pesquisas Tecnológicas - IPT, 1981. (IPT - Série Monografias, 5).

PINTO, H. S.; ZULLO Jr., J.; ZULLO, S. A.Oscilações Pluviométricas temporais no E. S. Paulo. In: Congresso Brasileiro de Agrometeorologia, 6., 1989, p. 29-33.

RIBEIRO, A. G. e SILVA, E. M. da. As tendências das variações climáticas na cidade de Uberlândia - MG (1981-2000). Caminhos da Geografia, v. 9, n. 12, p. 174-190, 2004. Disponível em www.ig.ufu.br/caminhos de geografia.html

RODRIGUES, R. A.; SANTOS, R. S. Estudo da Tendência Climática na Série Temporal de Precipitação Pluviométrica em Araguari (MG). Revista Geográfica Acadêmica, v.1, n. 1, p.20-27, 2007.

RONCATO, R. A. Variabilidade e tendência climática na região de Campinas (SP) e sua relação com o uso do solo. Rio Claro. 2002. (Tese de Doutorado) - Instituto de Geociências e Ciências Exatas - UNESP. 
ROSS, J. L. S. \& MOROZ, I. C. Mapa Geomorfológico do Estado de São Paulo, escala 1:500.000. Geografia-FFLCH-USP, IPT/FAPESP, São Paulo, vol. 1, 1997.

SALATI, E.; CAMPANHOL, T.; VILlA NOVA, N. A. Tendência das Variações Climáticas para o Brasil no Século XX e Balanços Hídricos para Cenários Climáticos para o Século XXI. Ministério do Meio Ambiente - Secretaria de Biodiversidade e Florestas - 1FBDS - Rio de Janeiro, RJ, 2 ESALQ/USP, SP.

SANT'ANNA NETO, J. L, ZAVATTINI, J. A. Variabilidade e mudanças climáticas: implicações ambientais e sócio-econômicas. Maringá: EDUEM, 2000.

SANT'ANNA NETO, J. L. As chuvas no Estado de São Paulo: contribuição ao estudo da variabilidade climática e tendência da pluviosidade na perspectiva da análise geográfica. São Paulo, 1995, (Tese de Doutorado) - Faculdade de Filosofia, Letras e Ciências Humanas da USP.

SANTOS, M. J. Z. As mudanças climáticas no Estado de São Paulo. Geografia. Rio Claro, v. 21, n. 2, p. 111-171, 1996.

SANTOS, M. J. Z. Variabilidade e tendência das chuvas e sua relação com a produção agrícola na região de Ribeirão Preto -SP. 1992. Tese (Livre Docência em Geografia) IGCE - UNESP. Rio Claro.

SANTOS, J. F.; PORTELA, M. M. Tendências e séries de precipitação mensal em Portugal Continental. Aplicação do teste de Mann-Kendall. Recursos Hídricos, v. 70, p. 32-45. Associação Portuguesa de Recursos Hídricos (APRH), ISSN 0870-1741, Lisboa, 2004.

SEN, P. K. Estimates of the regression coefficient based on Kendalls's tau. Journal of the American Statistical Association, v. 63, p. 1379-1389, (1968).

SENTELHAS, P. C. et al. Um século de desmatamento: efeitos no Regime Térmico, Pluvial e no Balanço Hídrico em Campinas, S.P., Revista Brasileira de Agrometeorologia, Santa Maria, 1994.

SENTElHAS, P. C., PEREIRA, A. R., ANGELOCCI, L. R. Meteorologia agrícola. Piracicaba, terceira edição. ESALQ, 2000. 
SENTELHAS, P. C.; ANGELOCCI, L. R. Variabilidade, Tendência, Anomalia e Mudança Climática. Material didático para uso exclusivo na disciplina LCE 306 - Meteorologia Agrícola Departamento de Engenharia de Biossistemas - setor de Agrometeorologia ESALQ/USP - 2010

SILVA, W. G. Análise geomorfológica como suporte à gestão ambiental: um estudo de caso. Rio Claro: Universidade Estadual Paulista "Júlio de Mesquita Filho", Instituto de Biociências, 1998. 123 p. (Trabalho de Conclusão do Curso - Graduação em Ecologia).

SNEYERS, R. Sur l'analyse statistique des series dóbservations. Gênevè: Organisation Méteorologique Mondial, 192p. (OMN, Note technique, 143), (1975).

SPIEGEL, M. R. Estatística. São Paulo: Makron Books, 1993.

STEINKE, E. T. Considerações sobre variabilidade e mudança climática no Distrito Federal, suas repercussões nos recursos hídricos e informação ao grande público. Tese de Doutorado. Universidade de Brasília, Instituto de Biologia, Departamento de Ecologia, 2004.

STORANI, D. L. Geossistemas e fragilidade de terras na bacia do rio Mogi Guaçu/SP. 2010. Dissertação (Mestrado em Geografia, Análise Ambiental e Dinâmica Territorial) Instituto de Geociências, Universidade Estadual de Campinas. Campinas, 2010.

SUGAHARA, S. Normais Climatológicas das estações de superfície do Brasil, para o período de 1961-1990. Bauru: Instituto de Pesquisas Meteorológicas da UNESP/Bauru, 1999.

SWART, S. e SANTOS, M. J. Z. dos. Mudanças climáticas e planejamento regional nos setores da depressão periférica e planície litorânea do estado de São Paulo: comportamento dos parâmetros térmicos e hídricos no período de 1955 - 1997. In: SIMPÓSIO BRASILEIRO DE CLIMATOLOGIA GEOGRÁFICA, 4, 2001, Rio de Janeiro. Anais. Rio de Janeiro: UFRJ. 1 CD ROM.

TAVARES, A. C. Variabilidade e mudanças climáticas. 2001. Tese (Livre-Docência), Instituto de Geociências e Ciências Exatas, Universidade Estadual Paulista "Júlio de Mesquita Filho”, UNESP, Rio Claro, 2001.

TAVARES, A. C. Mudança Climática. Mutuca: Jornal da Geografia, Rio Claro, maio, 2002, n. 1, p. 3. 
TAVARES, R. O clima de Sorocaba - SP: aspectos regionais, locais e urbanos. In: SANT'ANNA NETO, J. L. (Org.). Os climas das cidades brasileiras: São Luis (MA), Aracaju (SE), Campo Grande (MS), Petrópolis (RJ), Sorocaba (SP), Penápolis (SP) e Presidente Prudente (SP). Presidente Prudente: UNESP/FCT,2002. P. 115-143.

TUCCI, C. E. M. Impactos da variabilidade climática e dos usos do solo nos recursos hídricos. Brasília: ANA, 2002. 150 p. Relatório técnico.

VECCHIA, F. Clima e Ambiente Construído. A abordagem dinâmica aplicada ao Conforto Humano. 1997. Tese (Doutorado em Geografia) - Faculdade de Filosofia, Letras e Ciências Humanas, Universidade de São Paulo, São Paulo, 1997.

VIANELLO, R. L. e ALVES, A. R. Meteorologia básica e aplicações. Viçosa: Imprensa Universitária. 1991.

VILlA NOVA, N. A. Tendências Climáticas e Variações Climáticas. Revista Brasileira de Meteorologia, v.15, n.1, p. 123-129, 2000

VINCENT, L. A.; PETERSON, T. C.; BARROS, V. L.;MARINO, M. B.; RUSTIBUCCI, M.;MIRANDA,G. C. ; ALVES, L. M.; BARBOS DE BRITO, J. I.;BERLATO, M. A. ; GRIMM, A. M.; MARENGO, J. A; MEIRA, P. R.; MOLION, L. C.B.; MANCUNIL, D. F.; ANUNCIAÇÃO, Y. M. T.; SANTOS, J.L.; HAYLOCK, M. R.; KAROLY, D. Observed trends in índices of daily temperature extremes in South of America. 1960-2000. Journal of Climate, Boston, v. 18, p. 5011-5023, 2005.

WINKE, L. O. L.; DAMÉ, R. C. F.; TEIXEIRA, C. F. A.; MACHADO, A. A.; ROSSKOFF, J. L. C. Caracterização Climática e Estudo de Tendências nas Séries Temporais de Temperatura e Precipitação em Pelotas/RS. X Encontro de Pós-Graduação; 11, 12, 13 e 14 de novembro de 2008. Universidade Federal de Pelotas, RS.

WORLD METEOROLOGICAL ORGANIZATION (WMO). Disponível em: <HTTP://www.wmo.int/pages/index_en.html>

YEVJEVICH, V. Probability and statistics in hydrology. Fort Collins : Water Resources Publication, 1972. $276 \mathrm{p}$.

YUE, S.; HASHINO, M. Temperature trends in Japan: 1900-1996, Theoretical and Applied Climatology, v. 75, p.15-27, (2003).

YU, P.; YANG, T.; WU, C. Impact of climate change on water resources in southern Taiwan. Journal of Hydrology, Amsterdam, v. 260, p. 161-175, 2002. 
ZANCOPÉ, M. H. de C.; PEREZ FILHO, A. Considerações a Respeito da Distribuição das Planícies Fluviais do Rio Mogi Guaçu. Revista Brasileira de Geomorfologia, Uberlândia, Uberlândia, ano 7, vol. 1, 2006.

ZAVATTINI, J. A. Variações do ritmo pluvial no oeste de São Paulo e no norte do Paraná: eixo Araçatuba - Presidente Prudente - Londrina. 1983. (Dissertação de Mestrado) - Faculdade de Filosofia, Letras e Ciências Humanas da USP. 
Anexo A - Tabela com os valores da temperatura média anual no município de Pirassununga (SP) para a série temporal de 1976 a 2009.

\begin{tabular}{cc}
\hline Ano & T média $\left({ }^{\mathbf{0}} \mathbf{C}\right)$ \\
\hline 1976 & 21,6 \\
1977 & 23,8 \\
1978 & 23,2 \\
1979 & 22,7 \\
1980 & 23,6 \\
1981 & 22,4 \\
1982 & 22,6 \\
1983 & 22,5 \\
1984 & 23,8 \\
1985 & 22,7 \\
1986 & 22,6 \\
1987 & 22,6 \\
1988 & 22,5 \\
1989 & 21,8 \\
1990 & 22,6 \\
1991 & 22,5 \\
1992 & 22,4 \\
1993 & 22,5 \\
1994 & 23,2 \\
1995 & 22,9 \\
1996 & 22,5 \\
1997 & 23,2 \\
1998 & 23,3 \\
1999 & 22,7 \\
2000 & 23,2 \\
2001 & 22,8 \\
2002 & 22,7 \\
2003 & 21,7 \\
2004 & 20,4 \\
2005 & 21,5 \\
2006 & 21,3 \\
2007 & 22,5 \\
2008 & 21,8 \\
2009 & 21,4 \\
Med & 22,6 \\
\hline &
\end{tabular}


Anexo B - Tabela co os valores da temperatura máxima anual no município de Pirassununga (SP) para a série temporal de 1976 a 2009.

\begin{tabular}{|c|c|}
\hline Ano & $T \operatorname{Max}\left({ }^{\circ} \mathrm{C}\right)$ \\
\hline 1976 & 34,9 \\
\hline 1977 & 35,4 \\
\hline 1978 & 34,7 \\
\hline 1979 & 35 \\
\hline 1980 & 36 \\
\hline 1981 & 34,9 \\
\hline 1982 & 34,9 \\
\hline 1983 & 34 \\
\hline 1984 & 37 \\
\hline 1985 & 37,5 \\
\hline 1986 & 36,1 \\
\hline 1987 & 36,2 \\
\hline 1988 & 37 \\
\hline 1989 & 34 \\
\hline 1990 & 37 \\
\hline 1991 & 36 \\
\hline 1992 & 33 \\
\hline 1993 & 36 \\
\hline 1994 & 37 \\
\hline 1995 & 36 \\
\hline 1996 & 35 \\
\hline 1997 & 39 \\
\hline 1998 & 36 \\
\hline 1999 & 37,1 \\
\hline 2000 & 37,6 \\
\hline 2001 & 35,5 \\
\hline 2002 & 38,9 \\
\hline 2003 & 38,4 \\
\hline 2004 & 35,7 \\
\hline 2005 & 34,8 \\
\hline 2006 & 37,5 \\
\hline 2007 & 36,4 \\
\hline 2008 & 39 \\
\hline 2009 & 38,7 \\
\hline Med & 36,2 \\
\hline
\end{tabular}


Anexo C - Tabela com os valores da temperatura mínima anual no município de Pirassununga (SP) para a série temporal de 1976 a 2009.

\begin{tabular}{|c|c|}
\hline Ano & $\mathbf{T} \operatorname{Min}\left({ }^{\mathbf{0}} \mathrm{C}\right)$ \\
\hline 1976 & 4,2 \\
\hline 1977 & 5,2 \\
\hline 1978 & 0,7 \\
\hline 1979 & $-1,3$ \\
\hline 1980 & 3,5 \\
\hline 1981 & $-1,4$ \\
\hline 1982 & 5,2 \\
\hline 1983 & 2,3 \\
\hline 1984 & 1 \\
\hline 1985 & 1,5 \\
\hline 1986 & 3,8 \\
\hline 1987 & 1,4 \\
\hline 1988 & 1,3 \\
\hline 1989 & 5,5 \\
\hline 1990 & 0 \\
\hline 1991 & 5 \\
\hline 1992 & 7 \\
\hline 1993 & 4 \\
\hline 1994 & -2 \\
\hline 1995 & 5 \\
\hline 1996 & 1 \\
\hline 1997 & 2 \\
\hline 1998 & 3 \\
\hline 1999 & 3 \\
\hline 2000 & $-0,1$ \\
\hline 2001 & 3,2 \\
\hline 2002 & 0,8 \\
\hline 2003 & 3,7 \\
\hline 2004 & 2,4 \\
\hline 2005 & 3,4 \\
\hline 2006 & 2,3 \\
\hline 2007 & 3,6 \\
\hline 2008 & 3,2 \\
\hline 2009 & 2,8 \\
\hline Med & 2,5 \\
\hline
\end{tabular}


Anexo D - Tabela da estiagem climatológica para o município de Pirassununga (SP) no período de 1976 a 2009.

\begin{tabular}{|c|c|c|c|c|c|c|c|c|c|c|c|c|c|}
\hline Ano & jan. & fev. & mar. & abr. & maio & jun. & jul. & ago. & set. & out. & nov. & dez. & $\begin{array}{c}\mathbf{n}^{\mathbf{0}} \mathrm{de} \\
\text { dias } \\
\text { sem } \\
\text { chuva }\end{array}$ \\
\hline 1976 & 18 & 9 & 12 & 21 & 21 & 27 & 26 & 20 & 20 & 20 & 14 & 11 & 219 \\
\hline 1977 & 12 & 21 & 7 & 21 & 31 & 22 & 29 & 28 & 24 & 21 & 14 & 15 & 245 \\
\hline 1978 & 14 & 13 & 20 & 28 & 22 & 28 & 25 & 31 & 23 & 26 & 17 & 16 & 263 \\
\hline 1979 & 21 & 16 & 22 & 25 & 23 & 30 & 28 & 25 & 18 & 22 & 17 & 15 & 241 \\
\hline 1980 & 13 & 14 & 23 & 19 & 27 & 24 & 31 & 27 & 23 & 25 & 21 & 10 & 257 \\
\hline 1981 & 11 & 17 & 21 & 25 & 28 & 26 & 28 & 29 & 28 & 16 & 19 & 16 & 264 \\
\hline 1982 & 14 & 16 & 14 & 27 & 23 & 20 & 26 & 26 & 26 & 14 & 12 & 10 & 228 \\
\hline 1983 & 8 & 12 & 16 & 18 & 20 & 21 & 28 & 31 & 15 & 19 & 14 & 9 & 211 \\
\hline 1984 & 18 & 21 & 19 & 21 & 23 & 30 & 30 & 23 & 23 & 27 & 19 & 11 & 265 \\
\hline 1985 & 14 & 16 & 21 & 20 & 29 & 27 & 31 & 30 & 22 & 24 & 16 & 17 & 267 \\
\hline 1986 & 17 & 7 & 17 & 25 & 20 & 30 & 28 & 23 & 28 & 24 & 20 & 8 & 247 \\
\hline 1987 & 12 & 14 & 21 & 22 & 20 & 28 & 28 & 30 & 20 & 21 & 17 & 19 & 252 \\
\hline 1988 & 16 & 15 & 20 & 23 & 22 & 25 & 31 & 31 & 27 & 18 & 17 & 19 & 264 \\
\hline 1989 & 8 & 11 & 21 & 26 & 28 & 24 & 27 & 27 & 17 & 28 & 17 & 20 & 254 \\
\hline 1990 & 14 & 18 & 12 & 21 & 25 & 27 & 25 & 25 & 22 & 17 & 14 & 20 & 240 \\
\hline 1991 & 16 & 12 & 12 & 19 & 20 & 27 & 28 & 31 & 25 & 23 & 20 & 10 & 243 \\
\hline 1992 & 14 & 12 & 11 & 24 & 24 & 28 & 29 & 26 & 19 & 17 & 23 & 22 & 249 \\
\hline 1993 & 14 & 3 & 18 & 24 & 25 & 24 & 30 & 26 & 19 & 19 & 16 & 13 & 231 \\
\hline 1994 & 12 & 24 & 23 & 25 & 27 & 27 & 28 & 31 & 30 & 22 & 19 & 17 & 285 \\
\hline 1995 & 12 & 8 & 15 & 27 & 26 & 29 & 27 & 31 & 24 & 19 & 20 & 17 & 255 \\
\hline 1996 & 11 & 13 & 15 & 23 & 23 & 27 & 30 & 27 & 18 & 18 & 24 & 9 & 238 \\
\hline 1997 & 7 & 11 & 20 & 25 & 25 & 22 & 30 & 30 & 22 & 21 & 17 & 12 & 242 \\
\hline 1998 & 14 & 7 & 17 & 21 & 22 & 28 & 31 & 26 & 20 & 18 & 12 & 13 & 229 \\
\hline 1999 & 10 & 8 & 20 & 25 & 29 & 26 & 29 & 31 & 23 & 25 & 21 & 17 & 264 \\
\hline 2000 & 14 & 10 & 16 & 28 & 31 & 28 & 26 & 26 & 22 & 21 & 19 & 11 & 252 \\
\hline 1001 & 14 & 20 & 19 & 26 & 24 & 29 & 28 & 26 & 22 & 25 & 14 & 12 & 259 \\
\hline 2002 & 10 & 12 & 20 & 27 & 24 & 30 & 27 & 24 & 21 & 23 & 14 & 12 & 244 \\
\hline 2003 & 9 & 15 & 18 & 22 & 27 & 28 & 30 & 25 & 25 & 20 & 16 & 11 & 246 \\
\hline 2004 & 14 & 16 & 19 & 19 & 21 & 27 & 27 & 31 & 28 & 18 & 15 & 16 & 251 \\
\hline 2005 & 9 & 22 & 20 & 24 & 24 & 27 & 26 & 30 & 20 & 20 & 18 & 19 & 259 \\
\hline 2006 & 18 & 10 & 18 & 25 & 28 & 28 & 31 & 29 & 22 & 18 & 19 & 11 & 257 \\
\hline 2007 & 6 & 16 & 22 & 26 & 25 & 29 & 25 & 31 & 29 & 23 & 19 & 16 & 267 \\
\hline 2008 & 9 & 15 & 16 & 17 & 26 & 28 & 31 & 24 & 25 & 21 & 16 & 10 & 238 \\
\hline 2009 & 13 & 11 & 19 & 16 & 23 & 23 & 23 & 26 & 20 & 18 & 14 & 12 & 218 \\
\hline $\begin{array}{l}\text { Total dias } \\
\text { sem chuva } \\
\text { no período }\end{array}$ & 436 & 465 & 604 & 785 & 836 & 904 & 957 & 937 & 770 & 711 & 584 & 476 & 211 \\
\hline
\end{tabular}

